\title{
From "Infamy" to "Capacity Building"? The Shifting of Anti-Torture Strategies and the Problem of Torture in Turkey
}

\author{
by
}

\author{
Serif Onur Bahcecik
}

A thesis submitted to the Faculty of Graduate and Postdoctoral Affairs in partial fulfillment of the requirements for the degree of

Doctor of Philosophy

in

Political Science

Carleton University

Ottawa, Ontario

(C) 2011

Serif Onur Bahcecik 
Library and Archives

Canada

Published Heritage

Branch

395 Wellington Street

Ottawa ON K1A ON4

Canada
Bibliothèque et

Archives Canada

Direction du

Patrimoine de l'édition

395 , rue Wellington

Ottawa ON K1A ON4

Canada
Your file Votre référence

ISBN: 978-0-494-87766-1

Our file Notre référence

ISBN: $978-0-494-87766-1$

\section{NOTICE:}

The author has granted a nonexclusive license allowing Library and Archives Canada to reproduce, publish, archive, preserve, conserve, communicate to the public by telecommunication or on the Internet, loan, distrbute and sell theses worldwide, for commercial or noncommercial purposes, in microform, paper, electronic and/or any other formats.

The author retains copyright ownership and moral rights in this thesis. Neither the thesis nor substantial extracts from it may be printed or otherwise reproduced without the author's permission.
AVIS:

L'auteur a accordé une licence non exclusive permettant à la Bibliothèque et Archives Canada de reproduire, publier, archiver, sauvegarder, conserver, transmettre au public par télécommunication ou par l'Internet, prêter, distribuer et vendre des thèses partout dans le monde, à des fins commerciales ou autres, sur support microforme, papier, électronique et/ou autres formats.

L'auteur conserve la propriété du droit d'auteur et des droits moraux qui protege cette thèse. $\mathrm{Ni}$ la thèse ni des extraits substantiels de celle-ci ne doivent être imprimés ou autrement reproduits sans son autorisation.
In compliance with the Canadian Privacy Act some supporting forms may have been removed from this thesis.

While these forms may be included in the document page count, their removal does not represent any loss of content from the thesis.
Conformément à la loi canadienne sur la protection de la vie privée, quelques formulaires secondaires ont été enlevés de cette thèse.

Bien que ces formulaires aient inclus dans la pagination, il n'y aura aucun contenu manquant. 


\begin{abstract}
This dissertation aims to refine our understanding of anti-torture policies, by exploring globally circulating programs, strategies and policies deployed against torture and their configuration in Turkey. It argues that, since the end of the WW2, three distinct anti-torture strategies emerged. In the mid-1990s, anti-torture practices in Turkey shifted from a strategy based on naming and shaming towards a strategy based on prevention of abuses through improving the capacity of the police department.
\end{abstract}

Through a historical study of the problematization of torture it is claimed that while the legal abolition of torture has been the main formula developed in the Enlightenment period against the "infamy" of religious establishment, modern states went beyond this by adopting procedures of inquiry as the primary response to incidents of torture from the $19^{\text {th }}$ century on. The study also identifies three distinct anti-torture strategies (constitutional, accusatory and preventive) in the post-WW2 era that are differentiated according to the way torture is conceptualized, the repertoire of tasks and the actors prioritized. While the constitutional strategy relied on legal professionals to maintain a moral consensus, the accusatory strategy relied on shaming and naming tactics and the preventive strategy conceptualized torture as a problem of bureaucratic capacity, seeking ways to enhance state capabilities.

By using the strategies as analytics, the study then focuses on the Turkish context. The study argues that the constitutional strategy has not been potent in Turkey, and the accusatory strategy has been neutralized by the state to a certain extent. By focusing on the shifting ways in which torture has been conceptualized in official circles, it is found that from the mid-1990s on, torture has been understood by the state actors less as a 
problem of personal cruelty and more as a problem of technical incapacity of the police. This shift paved the way for the state actors to adopt a preventive strategy to combat torture and the participation of the police in this strategy. It is also found that this shift has been facilitated by dynamics of police/military relations and augmented by the European Union twinning projects to improve state capacity in Turkey. 


\section{Acknowledgements}

This dissertation has taken several years to complete and along the way I was indebted to many people. Unfortunately, providing a complete list of these people here is not possible. First, I would like to thank the members of my committee, Achim Hurrelmann and Christiane Wilke for their support, guidance and intellectual stimulation throughout the years. I also owe a debt of gratitude to my supervisor William Walters whose never-ending encouragement, generosity and intellectual input made this dissertation possible. He was always there to help and never complained of writing "progress reports" every six months. Without his guidance and the discussions we had, it would not be possible to turn my two-page "proposal" into a 100,000 word dissertation. I also would like to thank Chris Rumford and Paul Heinbecker who have taken the time to discuss this work with me.

Financially, this work was facilitated by the Council of Higher Education in Turkey, and Carleton University. A travel grant from the Center for European Studies at Carleton based on a funding from the European Commission and the Faculty of Graduate Studies and Research made research trips to Brussels and Vienna possible. I also would like to thank the chairs of the Department of International Relations at METU, Atila Eralp, Meliha Benli Altunışık and Hüseyin Bağc1, for their support and patience.

Many people helped me during my fieldwork, not only by giving their time for interviews but also by arranging access to other informants. In this regard I would like to thank Burhanettin Çakar, Adnan Gerger, Karl-Heinz Grundböck, Saadettin Tantan, Mualla Tüzün, İsmail Yllmaz and many others whose names I cannot provide here. Let 
me note that the claims in this dissertation by no means reflect their opinions or imply their approval of my views.

My parents-in-law Kıymet and Tuncer and my sister-in-law Gözde were always supportive and never protested for not being able to see Hande in the last several years. I also thank my Mom and Dad who always encouraged me and provided unconditional support throughout the years. My Mom Nurgen's positive mood and my Dad Erdoğan's confidence in me always motivated me to go on. It is not possible to express my gratitude to my wife Hande in words. She was more than generous in supporting me. Her belief in me and her love provided the lifeline throughout the writing of this dissertation. I dedicate this work to Hande who shared the "agony" of completing this dissertation. 
List of Abbreviations and Acronyms

AI

ANAP Motherland Party (Anavatan Partisi)

AP

CCP Turkish Code of Criminal Procedure

CEEC Central and Eastern European countries

CJS Criminal Justice System

CMUK Criminal Proceedings Procedure Law (Ceza Muhakeme Usulï Kanunu)

CPT European Committee for the Prevention of Torture and Inhuman or

Degrading Treatment or Punishment

CSOP Commission to Study the Organization of Peace

DP

ECtHR European Court of Human Rights

EU

GDS

HRA

HRC

HRW

IMF

ICJ

JDP

LI

MP
European Union

General-Directorate of Security (Emniyet Genel Müdürlüğü, EGM)

Human Rights Association

Human Rights Council

Human Rights Watch

International Monetary Fund

International Commission of Jurists

Justice and Development Party (Adalet ve Kalkınma Partisi)

Liberal Institutionalism

Member of Parliament 
NPAA National Program for the Adoption of the Acquis

OMC Open Method of Coordination

OSCE Organization for Security and Co-operation in Europe

PMC Permanent Mandates Commission

PKK Kurdistan Workers Party (Partiya Karkerên Kurdistan)

RPP Republican People's Party (Cumhuriyet Halk Ftrkast/Partisi)

TA Technical Assistance

TBMM Turkish Grand National Assembly (Türkiye Büyük Millet Meclisi)

UN United Nations

UNCAT United Nations Convention against Torture and Other Cruel, Inhuman or

Degrading Treatment or Punishment

WW1 First World War

WW2 Second World War 


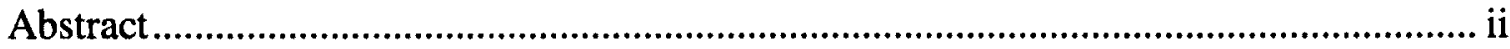

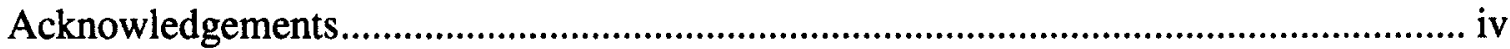

List of Abbreviations and Acronyms............................................................................. vi

Table of Contents........................................................................................................ vii

List of Tables, Figures and Appendices .......................................................................... X

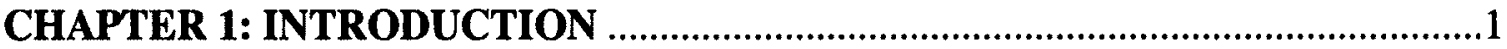

1.1 Statement of the Research Questions ..................................................................14

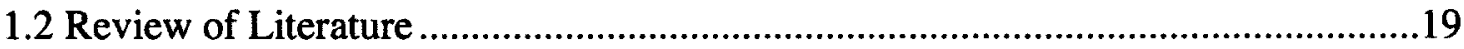

1.3 Methodological Considerations .........................................................................43

1.4 Chapter Outline ..................................................................................................49

CHAPTER 2: ANTI-TORTURE: HISTORY, PROBLEMS AND STRATEGIES ..52

2.1 Problematization of Torture in the Enlightenment ..................................................59

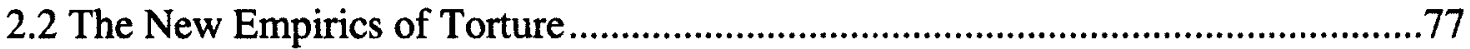

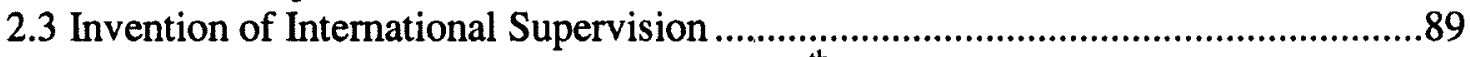

2.4 Strategies of Human Rights Protection in $20^{\text {th }}$ Century.........................................103

2.4.1 The Constitutional Strategy ............................................................................110

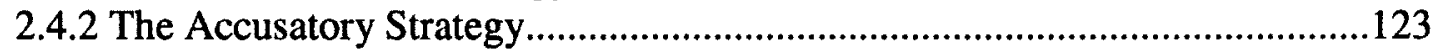

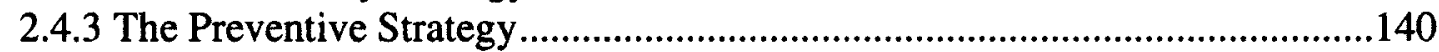

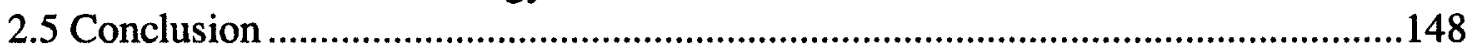

CHAPTER 3: HUMAN RIGHTS AS A POLITICAL PROBLEM IN TURKEY ..153

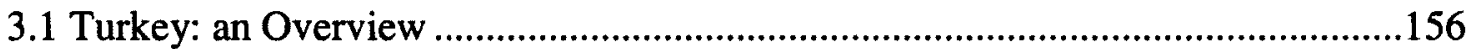

3.2 The 1971 Coup and the Emergence of Torture as a Problem.................................161

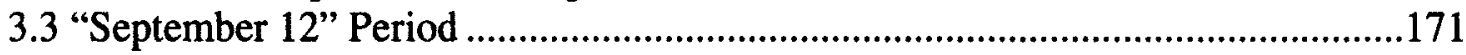

3.4 Problematization of Allegations of Torture: 1980-1995 ........................................174

3.4.1 Definition of the Official Policy ...............................................................175

3.4.2 Transition to Civilian Rule and Combat against Allegations ...........................181

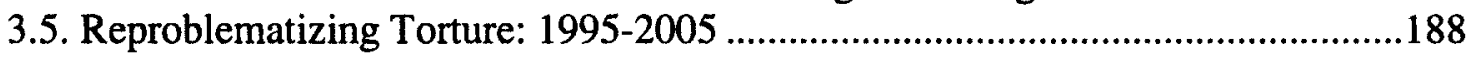

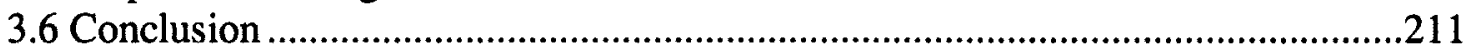

\section{CHAPTER 4: THE PARTICIPATION OF THE POLICE IN ANTI-TORTURE}

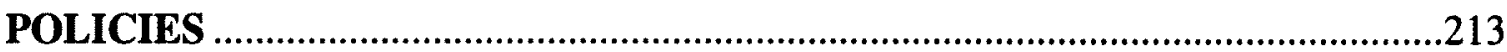

4.1 Networks and Fields of Power..........................................................................2214

4.2 The Police and the Army: A "Brotherly" Relationship .......................................218

4.3 Policing in the 1960s: A Springtime of Repression............................................221

4.4 Police during 1980s: Purge, Discipline and Foster...........................................228

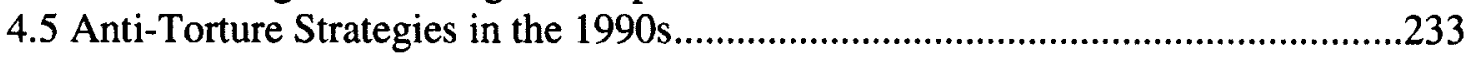

4.6 The Vernacular Discourse of the Police .............................................................24

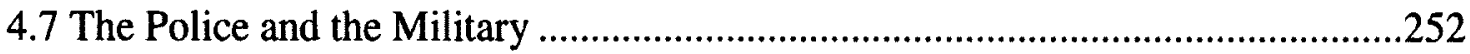

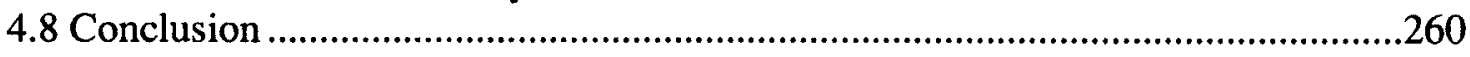


CHAPTER 5: TWINNING AS A MECHANISM OF INTERNATIONAL

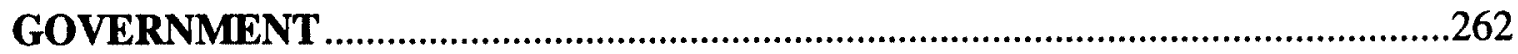

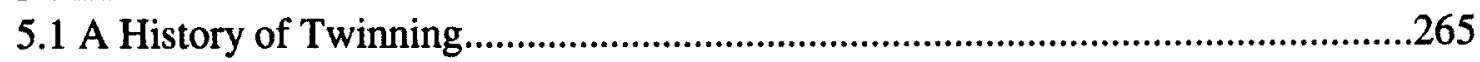

5.2 The European Union and Twinning …………................................................276

5.3 Turkey's Accession Process and Twinning ..............................................................289

5.4 Twinning Projects Relating to Police and Torture in Turkey ..............................291

5.4.1 Strengthening the Accountability, Efficiency and Effectiveness of the Turkish

National Police......................................................................................................293

5.4.2 Strengthening Police Forensic Capacity ..............................................................305

5.4.3 Statement Taking Methods and Rooms ...........................................................314

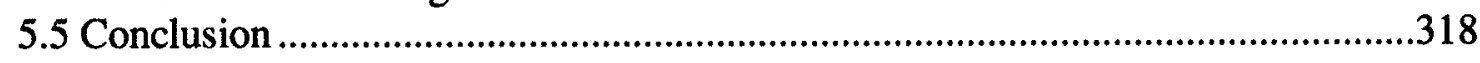

CONCLUSION …

Multiplicity of Anti-Torture Policies..........................................................................321

The Question of Torture in Turkey.............................................................................327

The Implications for Culturalist Approach to Human Rights .......................................328

The Future of Anti-Torture Policies ...............................................................................331

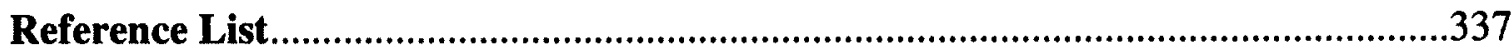




\section{List of Tables, Figures and Appendices}

Table 2.1

Figure 2.1

Figure 3.1

Appendix
110

69

173

369 


\section{CHAPTER 1: INTRODUCTION}

On 19 March 2001, the Turkish government adopted the National Program for the Adoption of the Acquis (NPAA). This document, also known as the 2001 National Program, was a 796-page text in which the government made a comprehensive list of promises to the European Union (EU). All countries aspiring to join the European club in the 1990s had to produce similar texts that regulated their negotiations for membership. The pledges included in the text, with their timetables and costs, provided the details of Ankara's plan to meet the requirements of EU membership. In the National Program, the government vowed to do whatever necessary to secure admission to the EU. After all, membership in the EU was seen as the logical consequence of Turkey's national modernization project. ${ }^{1}$ The government promised to ensure the free movement of goods, capital and persons; it would provide greater freedom not only for foreign entrepreneurs willing to invest in the country but also for the expression of all kinds of peaceful ideas. Apart from expanding liberties, the government would tackle some unwanted things as well. It would fight against organized crime, racism, piracy, auto theft, animal diseases, torture and other problems.

In the sub-section entitled "Fight against Torture" (Council of Ministers, 2001, p. 22-23) the government announced that it has already taken some measures in 1999 to address this problem. These included a circular ordering the effective implementation of laws and strict supervision by superiors; amendments to the penal code to align it with

\footnotetext{
${ }^{1}$ The fanfare that accompanied the announcement of the document betrays the importance given to this program. The Deputy Prime Minister Mesut Yilmaz remarked that the National Program was "a great transformation project" that aimed at a "fundamental revision of Turkey's political, economic, social and administrative structure" (Hürriyet, 2001b) while the Secretary General of the Directorate of EU Affairs Volkan Vural, a diplomat, stated that it was the project to "save" the country (Demir, 2001). The fact that Turkey was going under a grave economic crisis may help explain the celebratory tone of the statements.
} 
international conventions; increased penalties for torture; laws to speed up prosecution of public personnel; and authorization of the Human Rights Directorate to undertake studies to prevent incidents of torture. The cabinet also promised to review the police powers act and the relevant legislation, modernize the Forensic Medicine Institution (which provides expertise on court evidence, including findings of torture), adopt a new penal code, allocate resources for police training and improve legal provisions on the liability of perpetrators of torture.

The government proclamation of the "fight against torture" was certainly a very significant event. In the last several decades, human rights issues in Turkey have increasingly been scrutinized by non-governmental organizations, Western governments, and international organizations. ${ }^{2}$ Among these issues, torture has been a topical one embarrassing Turkey in the international fora, particularly since the 1980 coup d'état. Although military rule ceased in 1983 , law enforcement personnel have frequently been implicated with accusations of torture. The European Court of Human Rights (ECtHR) issued several judgments finding Turkish state in violation of Article 3 of the European Convention on Human Rights, which pertained to the right to be free from torture or inhuman or degrading treatment or punishment (for instance see European Court of Human Rights, 1996, 1997).

Turkey has signed or ratified most international human rights documents. It was one of the signatories of the Universal Declaration of Human Rights of 1948 prohibiting torture and ill-treatment as a "common standard of achievement." A member of the

\footnotetext{
${ }^{2}$ Indeed a study published in 2005 calculated that Turkey has been the subject of 396 of the 10075 background reports authored by human rights group Amnesty International from 1986 to 2000 . Soviet Union/Russia and China came second and third respectively in terms of the number of reports issued (Ron, Ramos, \& Rodgers, 2005).
} 
Council of Europe in Strasbourg, it ratified the European Convention on Human Rights in 1954. The "UN Convention against Torture and other Cruel, Inhuman or Degrading Treatment or Punishment" of 1984 that defined and banned torture was also signed and ratified by Turkey in $1988 .{ }^{3}$ Moreover, Turkish republican constitutions have expressed respect for human rights as one of the basic principles of the republic.

Nevertheless, official conduct always had an air of ambiguity towards human rights in general and torture in particular. Human rights progress was seen as a symbol of reaching "the level of contemporary civilization" while human rights advocacy or activism were sometimes considered as a plot to weaken the integrity of the state (Cali, 2007). To give an example, authors of a human rights report were charged in 1994 with engaging in written propaganda "aimed at damaging the indivisible unity of the Turkish Republic with its territory and nation," only to be acquitted in 1995 (Turkiye Insan Haklari Vakfi, 1996, p. 81). At times, human rights activist were seen as traitors conspiring with Western actors to undermine the stability of the Turkish state. To understand this ambivalent attitude towards human rights (activism), we need to understand Turkey's relationship with the Western Other. Turkey's bid for membership in the European Union has always been understood within the framework of Turkey's Westernization and modernization. Deepening the relationship with the West and with Europe in particular was a national ambition. The official Turkish identity has been under the influence of what Partha Chatterjee (1993, p. 2) called the "Eastern nationalism" (Kadioglu, 1996). In this kind of a political ideology found in the non-Western states, the economic and political development of the nation is understood in comparison to Europe,

\footnotetext{
${ }^{3}$ Turkey officially signed the document on 25 January 1998 and ratified it on 2 August 1988.
} 
which defines the civilization par excellence. In Eastern nationalism, the Old Continent is admired and emulated but there is simultaneously the awareness that this civilization is "alien" and foreign to the nation. In the Turkish context, progress in the field of human rights and Westernization are often seen as synonyms while Europe is not only the representative of an alien culture but may also invoke the memories of the War of Independence against the Allies after the First World War. In this way, concern for human rights is caught up in a constant tension between being part of the West and defending the nation or the state from the conspiracies of the same West.

It should be pointed out that this tension is also exacerbated by the Orientalist undercurrents found in the European criticism of Turkish human rights record. Orientalism, defined broadly by Edward Said as "a style of thought based upon an ontological and epistemological distinction made between 'the Orient' and (most of the time) 'the Occident"' (Said, 2003, p. 2) has been lurking in the background of many European interventions in the problem of torture in Turkey. A case in point is the eventful Luxembourg summit of the EU in December 1997. This meeting of EU heads of state and government was a significant one. One of the main items on its agenda was deciding the response to the applications by several states for membership in the European club. While the summit decided to start negotiations for membership for several countries (such as Poland, Hungary and Cyprus) who have applied very recently, Turkey's 33 years old hopes were once again dashed amid fears of Turkish immigrant influx into Europe. Problems in the field of democratization and human rights were mentioned as the main reasons for EU's decision to reject Turkey. However, this was expressed in a way that homogenized the West and Turkey as radically different entities representing the 
Occident and the Orient. The Luxembourg Prime Minister Jean-Claude Juncker remarked that a country where torture persists cannot "sit at the table of European Union" (Hockstader, 1997). He further argued that "no one is tortured in these [other 11 applicant] countries, but this is not the case, unfortunately, in Turkey" (Swardson, 1997). In this way, Juncker attempted to establish an unproblematic relationship between being "European" and lack of torture in a country. The Luxembourg summit had thus become the venue of airing fears of not only the Turkish invasion of Europe, but also the sneaking in of the "Terrible Turk." The Orientalist manner of the rejection of Turkey's application was not limited to this homogenizing attitude. As Mutua (2001) points out, "narrative of human rights" often codes the West as the "savior" and thus constructs a hierarchical relationship between the Occident and the Orient. This is apparent in the way the French President Jacques Chirac -presumably a supporter of Turkish accession- tried to soften the impact of EU's rejection. He remarked that the EU "should assure the anchoring of Turkey in Europe. It's the best way to guarantee this evolution of this country toward democracy and economic development" (Swardson, 1997). So, the alternative to the exclusion of Turkey was French paternalism which saw engagement as the best policy to tame the Turkish state.

When Turkish ambivalence is considered, the official proclamation of the "fight against torture" becomes more meaningful. Finally, one could say, the state not only unequivocally admitted the existence of torture and ill treatment in the country but also pledged to take concrete measures to prevent and eradicate it. The government has finally demonstrated the political will necessary to solve human rights issues that have been for so many years standing as an obstacle to Turkey's full integration with the global 
political and economic system. Yet, this is not the only interpretation available for this event. This proclamation was not only a sign that Ankara got "on the right track." It was also a new way of thinking about torture. In the National Program, the government inscribed the fight against torture almost naturally among other bad things like racism, organized crime, diseases and so on. Simultaneously, it admitted that torture and ill treatment was a problem in the country.

Compare this to the constitution of domains such as the population and the economy, which were delineated and separated from other objects of government. The act of governing often defines social domains as exogenous to the government itself and treats them as entities with their own regularities and features (Foucault, 1991a). Foucault observes that from the $18^{\text {th }}$ century on, the political problematic shifted from a concern to control territory (sovereignty) towards increasing the welfare of the population. In this way, population emerged as a distinct object of government. With the help of the science of statistics, the population was constructed as a body of people with "its own regularities, its own rate of deaths and diseases, its cycles of scarcity," that is to say a problematics of the population emerged (Foucault, p. 99). Rather than commanding its subjects, the ruler now had to act upon the population through various direct and indirect means to increase the well-being of this autonomous biological and social domain of population. A similar process can be seen in other domains as well. For instance, "the economy" understood as "the totality of the relations of production, distribution and consumption... within a given country or region" (Mitchell, 1998, p. 82) was a notion that rose between 1930s and 1950s. Mitchell showed that political, social and scientific practices constituted "the economy" as a "self-contained" and autonomous sphere only 
after the end of the Second World War. This is not to say that economic transactions did not exist before the 1930s, but that this domain was carved out of the human activity and came to be thought as a specific domain that required specific ways of thinking and technologies to act upon.

A similar notion of distance and autonomy was reflected in the government's declaration. Unlike issues that are supposed to originate in the society (non-systemic racism, crime) torture is not traditionally thought to be occurring in an autonomous space over which state has no authority. It takes place in the state's domain, on which the government claims direct control. After all, torture and ill treatment were mostly taking place in police stations, prisons and other enclosed spaces, which an international lawyer called sancta sanctorum (holy of holies) of states, that is, spaces where states are adamant to prevent others from seeing and entering (Cassese, 1996, p. 1). Consequently, this proclamation of the government was an act in constituting a domain in which torture and ill treatment transpired. ${ }^{4}$

Once the proclamation was made and torture was theoretically separated from the state, this language of "combat" was adopted by many public actors, some of which had a problematic relationship with human rights. Political leaders, rendered legally responsible and culpable for human rights violations in certain legal discourses, were now able to talk

\footnotetext{
${ }^{4}$ This declaration of the combat against torture can be read in conjunction with the growth of an official statistics of torture. In 1989, the Turkish Ministry of Justice started to collect information on the cases opened in criminal courts according to the article of the penal code. In this way, it became possible to see how many cases of torture were brought to the courts in a year, and the number of defendants. In 1994, the same ministry began collecting information on the outcome of the legal cases (e.g. conviction, acquittal, abatement and other). These statistics did not include information regarding the decisions about individuals, such as how many was acquitted or convicted. From 2002 on, information regarding how many individuals received what kind of judgment became available. There is no information regarding the number of public officials convicted of torture and ill treatment before 2002. This lack of statistical knowledge also exposes the fact that the state did not consider intervening in incidences of torture through a statistical knowledge of legal cases. See (Adalet Bakanligi, 2007; Bianet, 2007).
} 
about their fight against torture as if it was an entity, like diseases or criminality, beyond their effective control. In its webpage, the police department anti-terrorism unit not only talked about its successful operations against terrorist groups but also boasted of the progress it has registered in its struggle against torture (Terorle Mucadele Dairesi Baskanligi, n.d.). This language differed from the two main forms of discourse against torture in Turkey. One was the discourse of intellectuals that often characterized torture as a crime of the state. This way of seeing torture was ubiquitous in Turkey in the early 1970s and 1980s, following the military interventions and adopted an accusatory stance towards the state. Second, the "fight against torture" notion propounded by government was also different from the language adopted by the parliamentary human rights inquiry commission. Established in 1990, this commission's basic mandate was to examine Turkey's human rights practices, monitor compliance with international and national legislation concerning human rights and make recommendations for reform to the relevant authorities (TBMM Insan Haklarini Inceleme Komisyonu, 2009a). The actor that was under the spotlight was defined as "Turkey" rather "the state," "officials" or private authorities. The wording reflected a very broad perspective without singling out any potential abusers. Moreover, the commission invoked the image of a serene and rational inquiry towards human rights abuses, rather than a call for combat. ${ }^{5}$

These examples suggest that both the practices against torture and ill treatment are not natural reactions to acts of violation and that government's proclamation of "combat"

\footnotetext{
${ }^{5}$ The memoirs of a member of parliament who took an active role in the foundation of this commission indicates that the body sought to represent the "common sense" against both international actors that aimed to damage Turkish image and domestic actors that thought promotion of human rights amounted to treason (Akarcali, n.d.). Therefore the commission discourse was aimed to nurture a liberal but national position that would prevent the criminalization of legitimate criticism of state conduct.
} 
articulated a new conception. Multiple responses reflecting different starting points are possible. Whether they are formulated as a "combat" or an inquiry, practices contain a certain mentality. They evince a way of thinking about the state, torture, and subjects. These practices can be considered as "anti-policies" (Walters, 2008) which are a field of varied policies, programs, strategies, tactics that set out to prevent, eradicate, stop, or diminish bad things. ${ }^{6}$ Examples of these anti-policies are found in anti-corruption or antiracism polices which are deployed by both governmental and non-governmental agencies. As Hindess suggests, anti-policies have become so widespread that they cannot be analyzed only in terms of the activities that they fight. These practices have become "an important object of study" in their own right (Hindess, 2009, p. 20). It is these objects of study that I analyze in this dissertation.

Anti-policy is a useful concept to carve out an empirical field that has not been subject to extensive scholarly attention. Yet, limiting ourselves with the programs, policies and similar outputs may create the impression that anti-policies are "applied" smoothly over the social fabric without much effort and modification. I think that this tendency can be warded off by attending to the practices of actors involved in the process of "implementing" anti-policies, what Rose and Miller call "humble and mundane mechanisms" (Rose \& Miller, 1992, p. 183). Anti-policies give rise to new field of activity that connects and re-connects politicians, international experts, high-ranking bureaucrats, diplomats, corporations, public officers, citizens and so on. Certainly, it is not always possible to capture this field in all its complexity and vitality. But by looking

\footnotetext{
${ }^{6}$ It should be noted that "bad things" which are singled out from a wide spectrum of social harms reflect the political convictions of those who set the agenda on them and are socially constructed as much as the anti-policies designed to counter them.
} 
at the acts of association, cooperation, exclusion, subversion and modification between these actors we can get a fuller picture of anti-policies and their contexts.

Anti-policies involve the exercise of power. Here, I am talking about a Foucaultian notion of power, conceptualized as a relationship between actors. Rather than a capacity or resource that exclusively belongs to the state, power can be exercised by various agencies. Especially in its liberal form, it involves acting upon the actions of others (Foucault, 2000). This notion constitutes a stark contrast to the conception of power that is widely used in the human rights literature. In many studies, power is associated with the Leviathan state itself. Power in this sense is a capacity that usually contains the potential of transgression and the tendency to go beyond its legitimacy or limits that have been agreed upon by the citizenry when this power was transferred to the state. Human rights practices, on the other hand, are cast as pure acts of resistance, uncontaminated with political power. A case in point would be the work of a prominent American human rights activist, Aryeh Neier. ${ }^{7}$ In the introduction to his autobiographical book, Taking Liberties: Four Decades in the Struggle for Rights, he explains the ongoing vibrancy of human rights cause thus:

Commitment to human rights - at least in theory if not in practice - is among the few beliefs that thrive at the beginning of twenty-first century... It is, I think, a less dangerous faith than most other because it is not about the exercise of power [emphasis added]. Rather, the human rights cause, at least in the definition I favor

\footnotetext{
${ }^{7}$ Aryeh Neier worked for the American Civil Liberties Union for fifteen years. He left the Union and in 1978, and became one of the founders of Human Rights Watch acting as its executive director for 12 years ("About OSI," n.d.).
} 
that confines it to negative liberty, is mainly about limits on power. (2003, p. xxxiv)

When one remembers that in 1993 Neier became the president of the Open Society Foundations (OSF), an organization active in more than 60 countries worldwide, the claim that human rights is not about government or power looks less convincing. OSF was functional in training many activists and organizing Orange Revolution in Ukraine in the early 2000s (Traynor, 2004). What these activists did was not limited to "resisting"8 state power. Thus, this construal of human rights as "limits on power" seems paradoxical. Certainly, the point here is not that United States is utilizing OSF as a smoke screen in its geopolitical rivalry with Russia. The point is not that OSF or similar governmental and non-governmental agencies exercise sovereign power over a territory. Yet it is exercising power over subjects. For instance, in opposing electoral fraud and political corruption, they still govern the conduct of persons. In the case of Ukraine, this included the training of activists as unofficial "local election monitors" to conduct exit polls. This involved the technique of "parallel vote tabulation" where local monitors provide parallel information about the election result to challenge the official polling station results. Thus, I argue, human rights practices are not only about limiting power, but they also constitute a space of governmental activity by delimiting a domain, and helping to construct subject and objects. As Foucault (1980a) indicates in the first volume of his the History of Sexuality, discourses and practices constitute objects and subjects of government. While opposing injustices in a specific way, human rights practices also produce objects of governance such as poverty, homelessness, discrimination, etc. They constitute subjects by

\footnotetext{
${ }^{8}$ Indeed, in a Foucaultian framework resistance itself involves the exercise of power since power is not a capacity but the name of a complex and strategic relation (Gordon, 1980).
} 
addressing certain people as victims, perpetrators or activists. This kind of activity is not only defined with reference to what it opposes but "entails the production, multiplication and transformation of a complex network of objects, concepts, experts, practices and identities" (Walters, 2008, p. 275).

In this study, I look at the practices of human rights, more specifically at those against torture and ill treatment in Turkey. In line with the observations above, I argue that these practices cannot be subsumed under the rubric of human rights struggles as they go beyond a pure resistance to power. Moreover, categories favored by political scientists, such as national vs. international actors, non-governmental vs. diplomatic efforts, or legal vs. political measures are not always sufficient to exhaust the field of human rights activity against torture in Turkey. The analysis also needs to shed light to the history, rationalities, techniques, personnel, expertise of these practices. Anti-policies are more than automatic reactions to unwanted phenomena. Projects to eradicate and prevent torture in Turkey should be taken in their positivity, that is, their production of knowledge, constitution of subjects and objects, and assembling of different management techniques should be taken into consideration to understand this activity. In this context, the dissertation seeks to contribute to a new strand of studies on human rights that goes beyond what Fuyuki Kurasawa calls "formalist" and non-substantive paradigms (2007. pp. 6-7) in the study of human rights activity. The studies in these paradigms usually limit themselves to the study of international norms, global institutions for monitoring and enforcement and individual human rights groups and campaigns. Kurasawa argues that we also need to look at general patterns of the work of global justice to achieve substantive and critical understanding of these activities. Although my study does not 
focus on the ethical and phenomenological aspects of global justice, it explores the uncharted area that Kurasawa has rightly pointed out.

- The main arguments of the dissertation can be summarized as follows: Our understanding of the practices against torture and ill treatment needs to be refined by attending to the different logics, strategies and techniques at work. In this vein, I argue that the problematization of torture within the framework of human rights can be traced back to the Enlightenment period. While the abolition has been the main formula developed against torture in this period, modern states went beyond this by adopting procedures of inquiry and investigation as the primary responses to incidents of torture roughly from the $19^{\text {th }}$ century on. In addition to this, I also identify three distinct strategies against torture (constitutional, accusatory and preventive) and explore the different mentalities and techniques associated with them. I argue that, especially in "democratizing" countries, there has been a shift from constitutional and accusatory strategies towards preventive ones (more detail provided below).

- By using the strategies as analytics, I then look at the anti-torture policies in Turkey. I argue that, from the 1970s on, in the face of mounting allegations of torture the state adopted a policy of neutralization through limited acknowledgment of cases of torture, engagement with NGOs and attempted control of information regarding human rights abuses in the country. I also argue that while in the 1980 s torture has been understood by the state as a problem of personal cruelty; in the late 1990s it came to be seen as a problem of social development and bureaucratic capacity of the police. This shift in the official thinking made it possible for the state and the police to adopt projects to prevent cases of torture. 
- I extend this argument by showing that the police participated in reform efforts and the preventive strategy since they saw it as a means to further their professional interests. I demonstrate another instance of the advance of this strategy in Turkey by analyzing several twinning projects between Turkey and the European Union. Like the reform efforts of the Turkish government, these projects seek to prevent torture by improving the capacity of the police. I show that, rather than impunity, the focus of the EU experts has been on improving police working methods by promoting practical training, use of forensic data and new interrogation techniques.

\subsection{Statement of the Research Questions}

In the preceding pages, I have tried to show the utility of the concepts of antipolicy and productivity of power for my project. These concepts provide significant guideposts for framing the efforts against torture and ill treatment in Turkey. Notions of anti-policy and productivity of power help us to view human rights practices in Turkey in a different light. Usually human rights practices are told in terms of narratives of advances and regressions, ups and downs. For instance, the Freedom House in United States, an organization that promotes human rights worldwide, has been publishing an annual report called Freedom in the World since 1972 (Freedom House, n.d.). This report comprises all the countries of the world and evaluates annual performance of nations in terms of their observance of civil and political rights. The report then ranks these nations in terms of liberties and rights and notes the increase or decrease in violations of rights in countries. In this way, human rights practices are imagined as a set of rights that can be translated into fluctuating numeric values and their national and international progress be tracked through tables. This report has also become a reference for those interested in the 
state of human rights in the world, from academics to journalists. Thus, the first issue that my dissertation tackles is this narrative of progress and regress. Rather than analyzing human rights politics in terms of this dialectic, I ask how we can understand these practices without imposing on them a teleological thread linking the Enlightenment to the $21^{\text {st }}$ century human rights struggles. Introduction of the analytics of anti-policy and productive power help us see connections as well as discontinuities between $18^{\text {th }}$ century and our time. The proclamation of a fight against torture by Turkish authorities can be seen as a forward step towards fulfillment of human rights in a progressive narrative and hence a realization of the Enlightenment ideal. When a Foucaultian lens is used, however, these measures are seen as the production of knowledge on torture, a mutation in the way torture is viewed by state authorities, and an action on the conduct of state personnel. By using these heuristic devices, the dissertation first addresses the question of the history of human rights.

What kind of a history of human rights efforts -specifically anti-torture practicescan be written when we look at these events in terms of anti-policies and productivity of power? The notion of "event" as it is used in studies of governmentality is significant here to question the obviousness of the progress of human rights and the "rise and rise" of the struggle against torture. In Foucault (1991b, pp. 76-78), the use of the "event" indicates a willingness to expose two things: First, the "singularity" of structures and processes that have been assumed to be self-evident and secondly the multiple connections of events. Let me exemplify this by returning to the instance of Turkish government's declaration of the fight against torture. An eventalization perspective takes this not as the culmination of a forward march of history or globality (Shaw, 2000) but as 
"a breach of self-evidence" showing that the long-standing habits of non-recognition of torture as a political problem, and seeing allegations as conspiracies to destabilize the state or framing torture as a state crime were not the only ways to handle this issue. It was seen that torture could be unequivocally recognized and that it could be attributed to a domain beyond state's immediate control. This perspective also makes it possible to investigate this declaration as an event that has been constituted by "multiple processes" (Foucault, p. 76). While the most obvious among these processes is the EU candidacy, the declaration also needs to be seen within the framework of effective government of state agents, technicalization of police work, and affirmation of scientific expertise as a solution for political problems.

Another question that I address is the problematization of torture in Turkey. As indicated below, different anti-policies have their own specific ways of opposing and governing unwanted phenomena, based on a certain political mentality. Different views of the acts of torture, tortured subjects, perpetrators, and state, condition the strategies that are used in fighting against this problem. In studying anti-torture efforts in Turkey, the question then becomes which forms of state-sanctioned violence get to be seen as torture and how torture came to be seen as a political problem that required intervention by the state and non-state actors. What was the political context in which the state authorities resorted to violence? How did different authorities view or perhaps ignore the problem of torture and ill treatment in the country? What kinds of knowledges and expertise were deployed to represent and deal with this problem?

After looking at the problematization of torture in Turkey, I follow two axes of intervention in this problem. One axis is the interventions in and molding of police 
identity to eradicate torture and ill treatment. One of the crucial insights of studies of governmentality is its insistence on the significance of the identities of the governed for understanding the logic of rule and securing the targets of government. This point is shared by the Actor-Network Theory which will be introduced below. In this context, one of the most significant actors in the problem of torture in Turkey is certainly the police department. For many years, police officers have been the target of accusations of torture and ill treatment. They have been subjected to disciplining, reforms, and indictments. Therefore, an effort to understand anti-torture strategies in Turkey without looking at the police department would be missing an important element. I think that inclusion of the police into analysis is also important because police identities are a significant field towards which anti-policies are directed. In line with the idea of the productivity of power, anti-torture strategies also involve the construction of pro-human rights police identities. I ask what kind of police identities have been constructed in recent history. How did international human rights actors, governments and police officers themselves imagine the police identity? What has been the relationship between police identity and human rights? How did the reforms to improve human rights record of Turkey intervene in police identities? Did the authorities see changes in legislation or penalties on officers as sufficient? What kind of a discourse has been circulated to produce and justify a new type of police officer?

The second axis of intervention that I follow is the "twinning" projects carried out by the EU and Turkish government to bring law enforcement personnel behavior in line with human rights. While studies on Europeanization of candidate countries focus on "carrots and sticks," inter-state dialogue, diplomacy and links between Brussels and civil 
society groups in search for explanations in nation-state behavior, attention to twinning projects allows me to follow the practice European human rights governance. Especially in the mid-1990s, European authorities like the Council of Europe and European Union became increasingly involved in the problematization of torture in Turkey. As late as 1999, the EU Commission Progress Report on Turkey and Amnesty International's (AI) report indicated that torture was "widespread" in the country (Amnesty International, 2000; European Commission, 1999). It was reported that there were cases of torture and several deaths under custody. In many cases, accusations of death under custody were supported by medical reports. In the 2006 Progress Report of the EU, however, the Commission expressed satisfaction with the decline of cases of torture in Turkey, although complete eradication of torture was not yet the case (European Commission, 2006a, p. 13). This "decrease" in the occurrence of torture is usually explained in terms of the "conditionality" mechanism established between EU and Turkey where the latter is guided towards liberal and democratic practices with the promise of eventual inclusion to the European club. For instance a study concludes that recognition of Turkey as a "candidate country" to the European Union in 1999 has been effective in securing human rights reforms in 2002, such as the abolition of capital punishment and approval of a law enabling the education of and broadcast in Kurdish language (Schimmelfennig, Engert, \& Knobel, 2003). While such studies provide important insights into the international politics of human rights, conditionality is not the only mechanism utilized in this process. It functions along with other techniques of governance such as monitoring, diplomacy, and secondment of European experts to the candidate countries. The latter, also known as twinning, has become a technique that has been frequently used and one that allows the 
transmission of European norms to Turkish administrative apparatus. In this context, I address how such norms regarding torture are adopted in Turkey. While these rules are quite straightforward, their practical implementation and realization are not. Norms and laws prohibiting torture and ill-treatment do not go further than expressing what is not to be done. It falls on the shoulders of the authorities to implement these laws and norms. These principles may be put into practice in various ways. Addressing twinning projects between EU and Turkey allows us to look at what political scientists dub "norm transfer" (e.g. Flockhart, 2005) and compliance with EU norms in a different light. Taking conditionality as the only mechanism between EU and Turkey can be misleading when this concept leads us to treat all human rights legislation as equal. While in issues like death penalty a change in the legislation can be sufficient to revoke this practice, the same does not apply to human rights problems like torture and ill treatment. The latter requires more effort than simple change in the laws. What, then, are the principles that inform joint EU-Turkey initiatives to curb torture in Turkey? How are these initiatives different from previous efforts to eradicate this problem? Are the principles of these projects determined solely by the EU or are these norms and principles negotiated, between the Turkish and European authorities? Are these norms resisted and even subverted by the Turkish side? What does the deployment of twinning mean in terms of strategies to prevent torture? On what kinds of technicalization does twinning rely on to function?

\subsection{Review of Literature}

It is difficult to squarely locate this study within the precise limits of either the "Comparative Politics" or "International Relations" literatures. Rather than taking these 
fields as basic frameworks, engagement with bodies of work such as political sociology, Actor-Network theory and governmentality has been a deliberate choice to gain insights from various literatures. But this condition has also been a function of the field of human rights practices as well. As Todd Landman (2005) puts it, human rights are a "nexus for theories of international law, international relations and comparative politics" (p. 25). So this review of literature aims to engage with the studies on human rights norms rather than dealing with specific fields such as IR or comparative politics. More precisely, I engage with the "cultural approach" to human rights, that is, studies which attribute ideas and norms a certain level of significance in understanding anti-torture practices. Obviously, in this rendering human rights are taken as ideas and norms.

Before going into the detail of cultural approach it would be appropriate to consider a sophisticated theoretical framework which seeks to explain human rights and related ideas with reference to the national interest. Recently, a critical IR scholar, David Chandler has emphasized the centrality of states, or rather Western powers in the international political system. Chandler is highly critical of accounts which argue that non-state actors in global politics, especially non-governmental organizations, have become significant actors that shape the behavior of the state through networking and the power of norms. He argues that rather than being independent actors, NGOs are often "conduits for overseas aid and development funds" (Chandler, 2004, p. 45). Thus, according to Chandler, the adoption of international human rights norms are due to the power of Western states, rather than the mere moral activism of NGOs. Chandler opts for an approach that can show the relationship between the hegemonic ideas such as good governance and Western state interests (Chandler, 2004, p. 51). In this way, Chandler 
seeks to form a critical perspective that reaffirms the centrality of Great Powers while rejecting the narrow definitions of national interest as military or economic power. In the post-Cold War era, much like the post-WW2 era, Western elites were faced with a crisis of "domestic political legitimacy and elite coherence" (Chandler, 2004, p. 66) which they sought to overcome by propounding ethical foreign policy and humanitarian values in world politics. Chandler further argues that the multiplication of "good governance" or "capacity building" projects are the consequence of this search for moral capital and legitimacy. In later studies, Chandler also included the Western evasion of responsibility for decision-making as one of the main motivations of new forms international assistance and state-building that emphasizes partnerships and local "country ownership." He argued that the adoption of a language of power sharing with the "underdeveloped" nations and the rhetoric of partnership is due to the Western efforts to evade responsibility and accountability while implementing imperial policies in the nonWestern world (Chandler, 2006). Western states and international institutions impose policies and programs on non-Western states while simultaneously claiming that they are not exercising any political power but that the policies and programs they suggest are purely technical and non-political. What they do is simply to support the non-Western states in their endeavor.

The main concern of Chandler, however, in studying projects of good governance is to find out why there has been a shift from traditional discourses of democracy and the market (Chandler, 2006, p. 7). Although this is a crucial question and Chandler provides significant insights into the international assistance projects, my focus here is more about how power is being exercised. Moreover, conceptualization of international assistance 
and state-building in terms of the question of legitimacy and avoidance of accountability may prevent us from seeing these as an irreducible domain with its problematics, histories and technologies. The shift from traditional aid towards schemes of partnership may not always be due to the developments in domestic politics of Western states. This is because the "craft" of foreign aid has its own logics and histories which can be autonomous from the larger political and economic processes. The point I am trying to make is not that Chandler's argument is invalid but that it may need to be complemented with other frameworks to make a fuller sense of international assistance.

What Lichbach and Zuckerman (1997) call the "culturalist approach" has a long pedigree arguably extending back to Montesquieu. More contemporary representatives of this approach include the anthropologist Clifford Geertz who emphasized "thick descriptions," that is, narrative descriptions of cases often based on participant observation over analyses that saw individuals as mere utility maximizers. Such an approach sought to understand the meaning given to the events and actions by the actors themselves rather than focusing on the universal and rational interests of actors as prime motivations. Within the tripartite distinction between interest, institution and ideas-based theories provided by Peter A. Hall (1997), the cultural approach falls within the third category (ideas). Hall (p. 183) further identified three distinct groups according to the explanatory weight given to ideas. In the first group, ideas are seen as important elements but they are included in the analysis only when other variables fail to explain outcomes. This approach, which includes liberal institutionalism in the IR, suggests that ideas influence policy when they provide roadmaps in times of uncertainty. When there are multiple "pareto optimal" policy choices available to states, institutionalized ideas affect 
the preferences of the actors (Goldstein \& Keohane, 1993). ${ }^{9}$ Liberal institutionalists view human rights norms mostly as constraining structures that impose certain costs on the states and thus there is no rational explanation for compliance if it does not provide a sort of benefit to the state. The liberal institutionalist concern with objectively verifiable observations has guided this school towards the study of compliance with regimes or similar rule-based structures. In this way the "scope conditions"10 of institutions and their impact of state behavior understood as state behavior or foreign policy preferences can be determined. Mark Blyth (1997) is critical of the way this group within the culturalist approach attempts to bring ideas into picture. He points out that in this rendering, ideas are treated "instrumentally and functionally," that is, as entities that are "manipulated by individuals in the pursuit of their interests" (p. 231). Ideas are not simply instruments but they constitute the identities of the actors and thus make certain political practices possible.

This school of thought can be criticized for its limited conceptualization of how compliance with norms occurs. What is at stake in the process of compliance is not only rational state interests and availability of policy ideas. As will be elaborated below, states, and indeed all sorts of "macro-actors" should be taken as ensembles of micro-practices (Callon \& Latour, 1981). The formation of actors such as states require "negotiations, intrigues, calculations, acts of persuasion and violence" (p. 279) with the other actors in whose name the state speaks and acts. Thus, even if a focus on compliance is maintained,

\footnotetext{
${ }^{9}$ Note that both liberal institutionalist scenarios where ideas apply (uncertainty and previous institutions) are based on the consideration of transaction costs. Ideas reduce the transaction costs of state behavior by reducing uncertainty or preventing the costs of modifying previous policies.

${ }^{10}$ Determination of scope conditions are one of the main objectives of interest-based theories. They denote the instances where a certain institution has an impact on state behavior.
} 
it needs to take into consideration the work that government and high bureaucracy needs to accomplish (such as making legislation, gathering information, enrolling others) to ensure the cooperation of the population or other state actors. Moreover, the interests that state actors pursue, such as survival, wealth or prestige, are not objective and universal but contingent on and intelligible only within the context of prevailing political rationalities. This point will be clearer when I introduce the notion of governmentality below.

The second group within the culturalist approach attributes "higher causal priority" to ideas (Hall, 1997, p. 184). This group looks at the expert or epistemic communities and follows how some of their ideas become more authoritative in time leading to the adoption of policy paradigms. According to this second group, which is sometimes called "interpretive institutionalism," new practices and policies are adopted by governments basically because they "enhance legitimacy and are valued in the cultural environment" (Hall \& Taylor, 1996, p. 949).

The ideational approaches in IR are critical of the low-profile role accorded to ideas, norms and institutions by first and second groups of the culturalist approach. The third group, which often includes constructivist scholars, attribute "causal primacy" to ideas that constitute the identities of the actors and thus brings about "basic meaning systems that make action possible" (Hall, 1997). Wendt, a leading constructivist, argues that ideas should be taken as independent variables capable of shaping the policies of states through changing their identities in international politics (Wendt, 1995b). According to constructivism, a state complies with the normative ideas largely because its identity requires so. States pursue what is "appropriate" for their identities not merely 
because of some benefits or incentives but because they think that it is the "right thing to do" (March \& Olsen, 1998). Constructivism is distinguished from liberal institutionalism especially with the former's emphasis on identity as the basis of policy choices in world politics. According to the constructivist scheme, as certain norms and ideas became more salient in the ideational structure of politics, states, whose identities are constituted in part by this structure, seek to adapt themselves to the new situation. For instance, Sikkink attributes the growing US support for international human rights norms in the late 1970s to "changing ideas about the need to transform United States' role in the world" (Sikkink, 1993, p. 163). The deterioration of American image in the world has led to a search for a new policy and increasing significance of human rights in international politics made a change of heart in US foreign policy possible.

Similar to the interest-based theories, constructivist thinking often presumes that states have a fixed and stable identity that can be used as an index to state behavior. However, a state may espouse widely different, if not contradicting, identities at different platforms (Solomon, 2006). Therefore, empirical research needs to look at the local contexts of political practices to find out what kinds of specific logics, identities, values, etc. are at play.

In the 1990s, constructivists challenged the interest-based theories by showing that even high-politics issues like the national security can be explained with reference to the culture and normative structure. For instance, Katzenstein argued that balance of power and the optimization of state power were not sufficient to explain the actions of Great Powers in the aftermath of the Cold War (Katzenstein, 1996). Instead of exploiting the weaknesses of the Soviet Union, US foreign policy remained committed to 
multilateralism in its European policy, thereby taking into consideration the national interests of other European powers. According to Katzenstein this could be explained with reference to the internalization of multilateralism "as a constitutive part of some states' identities" (Jepperson, Wendt, \& Katzenstein, 1996, p. 62). The constructivist research program was also applied to issues such as military policies, an area where ideas were seen as least relevant. Richard Price (1995), for instance, has fruitfully employed Foucaultian genealogy to explain the persistence of Great Power aversion to chemical weapons. Price not only showed that the existence a cultural taboo against the use of chemical weapons has impeded the use of this weapon but also that the "glorious history" (p. 92) of the norm constructed retrospectively by norm entrepreneurs has concealed the fact that at the time of its adoption it was considered that the ban would not affect the preparations to use these sorts of weapons and that the ban was not important at all.

The problem with constructivism, however was that it relied too much on contextual explanations. Why were certain norms found in the institutional cultural context influential on some policies but not others or in some countries but not others (Checkel, 1998)? Checkel argues that constructivism requires a domestic theory to be able to explain such variances. The solution found within constructivism has brought some new insights but it is still problematical. In the attempt by Finnemore and Sikkink (1998) the need for specifying "ideational causal claims and mechanism clearly" has been recognized. The emergence of norms has been linked to some "norm entrepreneurs" who try to persuade political leaders for the acceptance of their proposals (Finnemore \& Sikkink, p. 896). The authors also claim that norms have a life cycle: After the 
introduction of norms by entrepreneurs and their acceptance by a "critical mass," they go on diffusing across the board (norm cascade) and then become internalized.

There are two basic problems with this conception. First, the authors again fall back to the argument of social context when trying to explain "norm cascade." It is argued that socialization is the main mechanism of norm cascade. In this process, norm leaders persuade others to adhere to norms. Actors at the receiving end of norms are persuaded because their identities shape their behavior. Their identities in turn are shaped by the "cultural-institutional context" (Finnemore \& Sikkink, p. 902). Therefore, Finnemore and Sikkink start with trying to find a solution to the indeterminacy problem in constructivism but after offering some specific mechanisms and processes for norm emergence, they go on explaining spread of norms with context and culture, which contradicts their initial objective.

Second problem is the idea of norm life cycle. Finnemore and Sikkink claim that norm cascade is followed by institutionalization. This means that norms become part of the "common sense" and are perceived to be the normal way of doing things. They are taken for granted. This idea reflects the predominant conception of "institutions" in liberal institutionalism. According to this, institution is a practice which one "expects to continue into the future and whose reproduction over time does not require active intervention" (Alderson, 2001, p. 419). However, this hardly reflects how practices are reproduced. Practices require day-to-day maintenance and intervention. For instance, the boundaries of nation-states, although they are taken for granted by many, have to be constantly patrolled, shown in maps, taught in schools, etc (Mitchell, 1991). The idea of institutionalization also conceals the problem of durability that is quite significant for 
those who are trying to implement a certain project and secure the effectiveness of a norm. Political orders are not constructed merely by some abstract norms but also by certain materials and devices which ensure their durability (Latour, 1991a). It is quite difficult to patrol the borders of a nation without the help of barbed wires, walls, land mines, unmanned aerial vehicles, etc.

The constructivist literature had significant implications for the study of human rights. Many scholars took up basic constructivist ideas on the effect of identity on state behavior to conceptualize politics of human rights promotion by European actors. This can be clearly seen in studies on the international actorness of European institutions like the EU and the Council of Europe. It has been argued that the EU was influential in setting the framework for the policies of Turkish governments. In this vein, Çavdar (2006) argues that some extreme conservative policy positions of Turkish politicians have been neutralized by the long-standing socializing relationship between Ankara and Brussels. Similarly, Bae (2008) argues that the Council of Europe experts succeeded in persuading the Ukrainian political elite through "non-public meeting sessions" (p. 140) to abolish the death penalty and pave the way for integration with the Euro-Atlantic structures.

Perhaps the contributions and limits of the constructivist thinking can clearly be seen in studies on EU's democracy and human rights promotion policies. Some students of European foreign policy (e.g. Diez, 2005; Manners, 2002) argue that the EU has constituted itself as a "normative" power that advocates democratization, rule of law, and human rights not only in its immediate neighborhood but around the world. The fact that the EU did not have the necessary capabilities to coerce and impose its will on 
undemocratic nations around the world, made it easier for it to settle for the "power of ideas" as a tool of policy making. The literature on normative power enhances the critical understanding of the functioning of power in international politics. In this vein, Manners comes close to a governmentality perspective on power by arguing that the EU's "ability to shape conceptions of 'normal' in international relations needs to be given much greater attention" (Manners, p. 239). Diez, on the other hand, challenges the presumption of fixed identity in the constructivist literature by showing how European officials can act according to different values and identities in different contexts. The example he cites is the words of Robert Cooper who later became the director-general of High Representative for EU's foreign policy. Cooper had posited that although European powers were pacified, this did not mean they would not employ military power at all. Military power could be necessary against residues of "uncivilized" social formations: "when we are operating in the jungle, we also must use the laws of the jungle" (Cooper as cited in Diez, 2005, p. 624).

My criticism of the constructivist literature focuses on two main points: the utility of conceptual tools for understanding relations of power and the conceptualization of the process of norm transmission. The focus of constructivist scholars on norms and ideas represents a significant contribution to the literature. Nevertheless, constructivists attribute too much force and agency to ideas themselves. Manners (2002), for instance, takes the contagion of ideas and information as a basic form of dissemination. He further argues that the mere actions of EU can be influential in that it can be seen to lead by example even if it does not directly promote its own values (p. 244). However, in studying political ideas we need to consider them along with practices. Ideas are neither 
free-floating nor directly applied to reality but deployed through certain political technologies. There exists an interdependent relation between the ideas and the objects on which they are applied and the technologies used. This point will be clearer when I discuss the notion of thought in governmentality studies below.

Often constructivists use a vocabulary that does not reflect the power aspect of strategic relationships. The notion of "social learning" constitutes a fitting example of this vocabulary. Checkel argues that constructivism provides two basic mechanisms of compliance. One is the "social protest/mobilization" mechanism where social actors put pressure on the state to change behavior and in time pave the way for norm internalization by state elites. As seen above, this mechanism suffers from an a priori model of norm cycle and contextual explanations. The second mechanism which Checkel underlines is "complex social learning" which is understood as a form of change in the interests and identities of actors "through and during interaction," namely a deliberative process where actors are convinced with rational arguments by experts (2001, p. 561). According to Checkel such argumentative processes constitute a contrast to manipulative communication in the form of mass propaganda which is asocial and lacks interaction (p. 562). This conception of communication is highly dualistic and implies that social learning is an uncontaminated form of communication that hardly involves tactics of power. However, communications that aim to convince "the other" are often calculated and thought out enterprises. They may involve theatricality and manipulation of built environment. Consider the difference between the effects of a lecture hall with a pitched floor and a room where participants sit around a round table. The former would be much less "democratic" and open to participation and would promote a conduct that involves 
passive reception of information. Communications may also incorporate a certain language that invests the relation between the interlocutors with power. ${ }^{11}$ While such tactics of power are recognized in settings like interview rooms used by police officers, they may be more subtle in international political life. Therefore, communicative practices, even if they are not instances of mass propaganda, are not sterile processes that involve the exercise of power.

Besides the shortage of conceptual tools to analyze "the conduct of conduct," constructivism can be reproached for its depiction of norm transmission. As can be seen from the brief review above, constructivist studies often fail to recognize that the "original" norms and ideas (sent by actors such as a norm entrepreneur or promoter) take a different shape and content at their target destination. As I will try to elaborate below, this is one of the significant contributions of the sociology of translation which shows that actors who convey the norms and ideas do so according to their own understanding and interests and may modify its content and practice accordingly (Latour, 1986). This is not only a process of filtration where local actors interpret ideas and norms according to their cultural background (Merry, 2010) but also a political process of manipulation where actors advance their own agendas with the help of borrowed norms and ideas. A case in point would be the dissemination of the Total Quality Management (TQM) philosophy in Turkey. TQM is a management discourse that emphasizes the participation of all elements of an organization in the improvement of products. This management discourse was appropriated by professional circles in Turkey and translated into a discourse of good governance that made it possible to link business communities, the

\footnotetext{
"A case in point could be the use of the term "recipient" in the twinning projects analyzed below.
} 
state and non-governmental organizations on the basis of an emphasis on quality of government (Ercek \& Say, 2008). In this way, what was considered as a business philosophy in its "original" context was turned into a justification for a campaign that sought to design government as a business process.

I suggest that the drawbacks identified in these studies can be compensated with the insight provided by studies of governmentality. Governmentality is a neologism used by Michel Foucault in his $1977-1978$ lectures entitled "Security, Territory and Population" at the Collège de France (Foucault, 1991a, p. 102). The particular lecture where Foucault first used the term related to the emergence, in Western Europe in the $16^{\text {th }}$ century, of the "art of government" defined by the contemporary French author Le Perrière as "the right disposition of things, arranged so as to lead to a convenient end" (as cited in Foucault, 1991a, p. 93). As Foucault shows, the art of government developed in contradistinction to what was seen as the Machiavellian precepts on sovereignty and the preservation of the power of the Prince. Whereas the sovereign form of power was preoccupied with the monarchical control over territory, the new art was about governing things understood as complex relations between people, territory, resources, wealth, etc. The ultimate end of the sovereignty was the entrenchment of the Prince's control over territory. The telos of government, on the other hand, was the welfare and wealth of the population. Moreover, Le Perrière's definition recognized that the conduct of conduct would be ensured through the generation of dispositions that would steer the subjects rather than through imposition of rules on them.

The notion of "the art of government" underlined the practical and technical aspect of the activity of government rather than the institutional structures or the ideology 
of political groups (Dean, 1999). The government came to be understood as a craft that involved reflection on who to govern, how to govern, for what ends, and the knowledges, techniques and tactics necessary for this practice. According to Foucault (1991a), there are various arts of government that employ different instruments, pursue different ends, and adopt different models of rule. Here, governmentality can be taken both in its general meaning as the art of government or in its historically specific form of liberal government. The latter pertains to a form of power which "has as its target population, as its principal form of knowledge political economy and its essential technical means apparatuses of security" (Foucault, 1991a, p. 102). In this definition, Foucault points out to the emergence of the population understood as a demographic and biological variable. The political economy, on the other hand, refers to the emergent sciences in the $18^{\text {th }}$ century which came to understand economy not in the Ancient Greek sense of affairs of the household and family but as knowledges that recognized the link between the capacities and features of the population and wealth. The apparatuses of security, on the other hand, referred to systems put in place to ensure welfare of the population, such as town planning, vaccination campaigns and measures to prevent food shortages (Elden, 2007, p. 564).

Foucault is better known for his studies on the aspects of modern society such as madness, surveillance and incarceration. Yet, many of his lectures in the last years of his life covered subjects such as the evolution of modern statehood. For instance, his "Security, Territory, Population" lectures (Foucault, 2007b) encompass a wide spectrum of state practices ranging from punishment to diplomacy. Although few of his lectures were published before 2004, the influence of Foucault's ideas on government went 
beyond his associates with the publication of the collection The Foucault Effect in 1991 (Bröckling, Krasmann, \& Lemke, 2011). Recently there emerged a significant corpus of studies in the English-speaking world taking up Foucault's basic insights and method. These studies sustained the broad notion of government in Foucault by showing relations of power in areas as varied as psychology (Rose, 1991), accounting (Miller \& Napier, 1993), global politics (Fraser, 2003) and risk and insurance (O'Malley, 2004).

This broad conception of government explicated by Dean as a "rational activity... employing a variety of techniques and forms of knowledge, that seeks to shape conduct... for definite ends" (Dean, 1999, p. 11) emphasizes several objects in political research. It focuses on "mentalities of government" understood as forms of knowledge, expertise, etc. oriented towards the conduct of human conduct. Here, mentality is not taken as an abstract political philosophy but rather as a "thought" relating to the practice of government (Dean, 1999, p. 16). This is a point that not only emphasizes the implication of sciences in the government of populations but also differentiates studies of governmentality from "ideational theories" that emphasize ideas as causal variables in international politics. Governmentality studies usually prefer the notion of thought rather than ideas to emphasize the practicality of thinking, that is, its relation to practice. Political thought intervenes in political problems, but the way it intervenes is in interaction with the way it represents the problem. Moreover, political thought differs from the constructivist conception of ideas in that the latter is more explicit (Walters \& Haahr, 2005b). Constructivists look for ideas in influential think-tank documents, and take them as concrete policy suggestions or agendas promoted by lobbies or "norm entrepreneurs". Political thought, on the other hand, is often less explicit and embedded 
in not only policy documents but in ways of seeing political problems or in built environments such as police stations or courtrooms. ${ }^{12}$ Studies of governmentality focus on thoughts that are considered non-political or extra-political. Once government is understood as the "conduct of conduct" it becomes possible to see how certain bodies of expertise and regimes of practices connect to "molar" ends of government. A case in point is the association of psychology with liberal government. As Nikolas Rose (1991) argues, psychological knowledges contribute to the government of human conduct by taking part in rendering individuals calculable subjects who "can be known, mapped, calibrated, evaluated, quantified, predicted and managed" (Rose, p. 93). The psychological tests and measurement of attitudes help manage social groups in factories, schools, hospitals and offices. Therefore such knowledges cannot only be treated as ideas embedded in a cultural context or objective and apolitical sciences but rather as devices invented to rule over subjects. Autonomy and individuality, as ends of liberal government, are also underwritten by psychological expertise that encourages selfevaluation of individuals according to these same norms.

A second object that is emphasized in studies of governmentality is the technology of government, that is, practical mechanisms, devices, calculations, procedures, apparatuses, and documents through which authorities seek to shape human conduct (Inda, 2005). These include mundane devices such as tables and graphs, signs, vocabularies, pedagogical techniques and built environments. Techniques "give a

\footnotetext{
${ }^{12}$ A case in point would be the way courtrooms are designed in Turkey. In a typical Turkish courtroom, the public prosecutor and the judge sit at an L-shaped or long desk, putting them at the same height while the lawyer is relegated to a separate table placed on the lower floor. The shape of the desk seems to confirm and reproduce the idea that prosecutor and judge are on the same side to defend the state and society while the self-interested attorney simply represents an individual. This situation contradicts with the principle of fair and impartial trial requiring that the prosecutor and the attorney be regarded as equals (anonymous public prosecutor, personal communication, July 1, 2007).
} 
concrete form" to political mentalities (Foucault, 2000, p. 410). Devices such as tables, graphs and reports not only represent the reality but also render it amenable to government. One such technology of government is discipline. Disciplinary technologies, mainly associated with prisons and schools, seek to produce docile and productive subjects (Foucault, 1979). Hierarchical observation, evaluation of behavior according to certain norms, and examination are aspects of this technology. Yet this technology is not only limited to classrooms or cells, it is deployed in international politics as well. For instance, the Organization for Security and Co-operation in Europe (OSCE), an intergovernmental organization with roots in the Cold War détente process, used similar techniques to shape the conduct of member states, especially those that are judged less liberal (Merlingen, 2003). The OSCE sought to shape the conduct of these countries by monitoring their conduct in issue areas such as policing, minority rights, military reform, and elections. States are differentiated into different groups according to the risk they pose to "comprehensive security concept" of OSCE. The organization also issues "report cards" to assess the conduct of member countries. By utilizing this technical assemblage the OSCE exercises a form of disciplinary power on nation-states.

Technologies of government also involve actual devices utilized to effect change in a certain order (Barry, 2001). Implementation of human rights legislation requires an assemblage of not only various actors such as police officers, inspectors, medical experts but also technical devices. The political science literature treats human rights and technology as two distinct spheres. Extant studies look at technology as a human right itself or attempt to explore how technological devices and surveillance can violate human rights (Metzl, 1996; Weeramantry, 1990). Technology relates to human rights only as a 
"rights issue." However, as seen in the Turkish case, the government makes extensive use of devices to bring about compliance with human rights legislation to prevent torture. One such project is the closed circuit television systems better known as MOBESE (Mobile Electronic System Integration) in Turkey. This is a system comprising several parts, or modules. One such part is called NIKS (standing for detention cell improvement and control system), where surveillance cameras viewing detention cells are installed in police stations (Istanbul Emniyet Mudurlugu, 2007). The images are monitored and recorded by a central unit in the police department where officers follow the cells around the clock. This system also includes a local component: Images of cells can be monitored by officers in the police station. In this way, officers can intervene if they detect a problem in the cell or if they get a message from the central control unit. The NIKS is not only seen as a device of mechanical external surveillance, but also a marker of the reform of the police department. More than just a device to discipline the police officers, the NIKS reflects the new police ethics that comes to terms with the human rights values. The official website of the system (Istanbul Emniyet Mudurlugu, 2007) reflects this new professional ethics by claiming that NIKS will "constitute a worldwide example regarding the respect of our country towards human rights." The NIKS functions more as an appeal to the identity of the police as a profession governed by ethics and less as a system of disciplining police officers. What is emphasized is not its function as a device of surveillance but rather its symbolic effect as the proof of the commitment of the Turkish police to human rights.

My emphasis on technological devices is inspired by the body of work known as the Actor-Network Theory (ANT). This is a perspective that first emerged in the 
sociology of science as an attempt to understand the formation of scientific knowledge and was later extended to other fields of study (Latour, 2000). This radical empirical body of work emphasizes the role of "non-human" actors in maintaining and building social and political orders. Bruno Latour, one of the pioneers of ANT, argues that explanation of order in social science mostly relies on social relations. Introduction of non-human actors in the picture helps us to see that technical devices replace the role played by humans especially in cases where human conduct is problematical. While humans need to be disciplined, or trained to act in certain ways, non-human actors that guide action in predictable ways can be built. Instead of unreliable humans, non-human actors are used (Latour, 1992).

The use of handheld computers in Turkey for identification of suspects provides an interesting example of how technology can be deployed to reduce the chances of abuse of human rights. In 2008 , the government started to deliver these devices to frontline police officers for use in communication with the headquarters and identification of persons (Balta, 2008). Besides improving the efficiency of routine police work, the handheld computers were touted as devices that would reduce the likelihood of abuses, or improve the accountability of policing. Before going into the detail of the workings of these devices, let us consider the problems that routine police work such as identification and communication pose.

Except in times of martial rule or state of emergency, Turkish legislation does not require persons to carry identification documents. However, every citizen is obliged to obtain a national ID card and in routine controls the police are authorized to request persons to identify themselves, and detain those who "cannot prove their identity" or act 
suspicious (Kaygusuz, 2008). As in many countries, these sorts of encounters between the police and civilians give rise to controversies in terms of human rights. Whether the police is unjustly targeting certain ethnic populations, or whether it is using the power of search to stigmatize political groups is often debated. Moreover, for many people routine controls are the only cases where they experience a contact with the police; a moment that shapes the citizens' impressions of the police officer. Thus, this encounter between the police and citizen is implicated in multiple political questions.

In routine controls, authorities aim to correctly identify people and detain the right persons if need be. This poses several problems. First, detention of innocent persons or those for which there is no search warrant amounts to ill treatment and should be avoided. The identification of persons should be preferably quick and made on the spot so that their freedom is not unjustly limited. Second, the authorities want to make sure that when police officers identify a person with a search warrant they do not turn a blind eye for personal or political reasons. When hand held computers were introduced to the police force, these intentions of government were loaded on this device (Balta, 2008). In routine controls, police could now see whether there is a search warrant for the person by checking the name or national ID number against a central database by using the handheld computer. This takes less time than identification of the person through radio communication and does not require taking into custody. The use of these devices also prevents abuse of authority because every query on the database is logged in, that is, recorded in the central database. The logs indicate which officer made the query, at what time and its result. If a wanted person's national ID number is queried, the police cannot 
turn a blind eye and let her go. In this way, mobile computers work to ensure human rights and impartiality of the police.

Besides mentalities and technologies, studies of governmentality also emphasize the identity of the governed as a key site of intervention. Government is about conducting the conduct of people. As the practice of power is transformed according to the shifting mentalities and justifications of government, new identities are presumed for the subjects (Veyne, 1997). This is not to say that a uniform identity is imagined for the subjects across all domains of practice. Rather, different power relations co-exist and they presume different identities for the governed and governors which may be conflictual, overlapping or mutually strengthening in different instances (Walters \& Haahr, 2005a).

The conduct of conduct is not only limited to the relations between the modern state and its population or to the domain of the personal. The art of governing understood as "the right disposition of things" is relevant for international politics as well. Such subtle and mundane guidance of conduct can be observed in not only relations between states but also in the practices of international organizations. An example would be the governance of states in the global economy. Students of global politics are well aware of the imposition of measures by IMF and World Bank to integrate nation-states deeper into the neoliberal world economy. Yet neoliberalism is also being instituted through less drastic methods. As Fougner (2008) suggests, competitiveness reports published annually by World Economic Forum and International Institute for Management and Development help constitute nation-states as economic competitors. These authoritative reports rank countries worldwide in terms of their potential for productivity and economic growth. They shape the conduct of states by objectifying them as "competitive market subjects" 
and by providing external reference points (benchmarks) to states through which they can understand their position in the world economy. This neoliberal state subjectivity coexists with the conception of states as security competitors or geopolitical rivals, and hence suggests different practices of statehood.

Studies of governmentality often focus on the government of individuals or populations, who, by definition, are located outside the domain of the state. Yet as Osborne (1994) reminds, the government of the nation-state involves the government of the state personnel and the bureaucracy as well. The fact that the government of bureaucratic personae can assume liberal and disciplinary forms shows that governmentality can co-exist with other forms of power. As mentioned in the above NIKS example, the state deploys tools of surveillance in its police stations to monitor police officer conduct. But the state also utilizes other techniques that seek to govern the officers through their freedom. As Nikolas Rose emphasizes, especially in contemporary liberal government, subjects are "obliged" to be free (Rose, 1999b, p. 87) and are expected to govern themselves. In many Western nations, social policies are in place, which presume a free citizen that makes responsible and informed choices for his own health, well-being and professional career. This has spilled over to human rights policies, where the state promotes the self-government of its officials by respecting their discretion and avoiding governing them too much through punishment or legal injunction. For instance, in a "Police Ethics" course given to police cadets in the Turkish Police Academy, students are advised to adopt an ethical conduct. This ethical conduct goes beyond the legal and disciplinary regulations that the police are obliged to follow. For instance, police are instructed to minimize use of force even in cases where it is 
justifiable. Where the laws do not provide the criteria of use of force, officers should search their soul and then act "within the framework of professional ethics" (Bal \& Beren, 2003, p. 86). These lessons and the textbook seek to constitute police officers not as applicators of state's legitimate violence but as specialists of security who consider the image of their profession and organization before acting. This inculcation of selfgovernment is then connected to wider governmental aims of improving human rights and the fight against torture. The government of the state in a liberal and democratic way relies on not only disciplining and punishment but also the construction of police officers' identity in line with police ethics and human rights.

Knowledge and technologies of government are not applied on a blank slate but on spaces where different identities, statuses, and conducts already exist. The governmentality perspective recognizes this state of affairs by emphasizing that the exercise of power takes into consideration the self-interests of the subjects. Yet, in order to capture how the projects of government play out and how relationships of power are constructed, we need to keep in mind the struggles and conflicts in a certain setting. To accomplish this, I turn to the sociology of Pierre Bourdieu and his followers and incorporate the notion of the field to better conceptualize the conflictual transformation of police identities in Turkey. The field is a space of struggle where different actors contest to acquire, increase or stabilize their capital. The capital is contingently defined within the context of the field, that is to say each field has a different capital of its own (Bourdieu \& Wacquant, 1989). The actors in the artistic field seek to attain symbolic capital, while the actors in the field of security strive to control legitimate monopoly of violence or knowledge on the threats. In analyzing the transformation of policing in 
Turkey, it will be apparent that the two players in the field of security, the police and the army, entered in struggles to improve their positions in the field. Thus, the Bourdieusien notion of field allows me to complement the study of discourses and practices with an analysis of the efforts to transform police identities. I will expand on this point while discussing the role of the police in the anti-policy of torture in Turkey in Chapter 4.

To summarize, the perspective adopted here seeks to shed light on political domains that do not appear in the map of the so-called culturalist approach. In capturing the broad field of anti-policies targeting torture, I draw attention to subjectivities and technologies of government with a perspective provided by studies of governmentality, and insights of international political sociology. In doing that, rather than looking for theses that are generalizable across time and space, such as "state behavior," I look for practices that have a certain history and specificity of their own, and that are transferable between different strategies.

\subsection{Methodological Considerations}

Studies of governmentality do not provide a sui generis methodology or research tool. Like many social science research it takes advantage of archival material, interviews, quantitative and qualitative data. The specificity of governmentality lies in its approach to this body of information (Kendall \& Wickham, 2007) and the way it redefines the archive. In analyzing such information, studies of governmentality does not treat the archive as objective and neutral data but as entry points for understanding and following govermentality's privileged entities, that is, mentalities, technologies and identities. As will be clearer in the following chapters; representations, data and other sorts of knowledge used by those who govern structures the way they govern a certain 
domain. This is also illustrated by Autesserre (2009) in a study on expert discourses on the violence in Democratic Republic of Congo. She explicates how the frame of representation adopted by experts in Congo shaped their action. When Congo was understood as a case of postconflict situation, violence became more acceptable and policy efforts were directed towards state-building and holding elections, rather than addressing the causes of violence. A similar operation was in place in the prevention of torture in Turkey. As much as it was seen as a problem of administrative capacity rather than state crime, efforts were directed towards increasing police capacity and prevention rather than punishment of police officers.

Besides bringing new interpretations to data, studies of governmentality expand the sources of social science by including what Foucault called "minor texts" (Foucault, 1997, p. 101) into the archive material. ${ }^{13}$ This inclusion of minor texts follows from the genealogical mode of investigation. For instance, in his lecture on governmentality, Foucault dwells upon the obscure texts that oppose Machiavellian logic of sovereignty and finds the ascendance of governmentality in this critical literature. In this way, antiMachiavellian writings are not read as philosophical studies but texts that articulate and develop new mentalities of rule. Moreover, minor texts can be used in an attempt to capture the materialized technologies of government. Texts such as self-help books and manuals are devices deployed to shape identities and constitute domains of government. For instance Philip (2009) demonstrates how individuals are encouraged to monitor and regulate their own mental health using self-help books, some of which are clinically

\footnotetext{
${ }^{13}$ Minor texts are obscure texts that stand outside the canonical literature. Foucault's emphasis on minor and obscure texts is closely related to his genealogical approach. By focusing on minor texts he hoped to detect the interactions and battles of different discourses, as a way to understand the relation between power and knowledge (Foucault, 1973).
} 
recommended. Such self-help books are not only guides to improve mental health but they have a political aspect and constitute individuals as active citizens, concerned about their own health and managing it in according to liberal precepts like "autonomy, rationality and productivity" (Philip, p. 161).

These methodological codes guide my study on human rights practices to prevent torture in Turkey. In conducting research, I utilized multiple sources of information such as archives and interviews. Besides sources from libraries such as the National Library of Turkey, several university libraries, the library of the General Directorate of Security (the official name of the police department), I was able to secure some limited access to some documents through informants. A comprehensive list of interviews is appended to the dissertation. Some of the interviews on the list are not cited in the text here. While some of the interviews with informants provided citable information for the dissertation, others proved to be essential for gaining an overall perspective of the transnational field of human rights activity. In addition to the use of newspapers from the 1960 s on, I also consulted police publications like Çă̆ın Polisi (Contemporary Police) and Polis Bilimleri Dergisi/Turkish Journal of Police Studies. The first journal is published by an association of retired police officers. The authors of the journal include not only the members of the association but also governors, police officers, academics etc. It usually publishes essays about the police profession. The second journal is more academically oriented, and authors are usually professors or students from the Police Academy. Additionally, I used sources such as Ozdemir (2001) which is a book written by a police officer. In using these publications, I assume that they are not only published to generate knowledge but also to shape the conduct of police officers. Indeed, the writings have a normative style 
that summons and calls upon the officers to behave in a certain way. Thus, I consult this material not as a passive source of information, but similar to the self-help books, a device deployed to shape the subjectivities of police officers. Certainly, these journals were not read and "internalized" by all police officers. Yet when the content of the journals are analyzed it is seen that they establish a very vital and active relationship with police body. This is observable in the fact that many of the contributors of the journals are active duty officers. Moreover, these journals were made available to many police stations through out the country. However, it must be emphasized that I did not engage in a measurement of the influence of this journal on police officers. Rather I treated them as one tool among many, and a site in which strategies to shape police identities were put to work.

Interviews with public officials, human rights advocates and journalist also proved to be significant sources of information for my project. In selecting the public officials for interview, I used three methods. First, I tried to contact the officials who were involved in police reform efforts in Turkey. These included officials from the European Union, or other officials whose names were available in the twinning project documents published by the EU delegation in Turkey. In the case of Turkish officials, to conduct interviews, I needed permission from supervisors of the interviewees. This has not always been possible and I was referred to other officials for interview. The second method I used to access informants was snowballing. Many informants helped arrange interviews with other officials, who were otherwise quite difficult to access. The third method of selection was more random. I asked help from people close to bureaucratic circles to acquaintance me with public officials. This also proved to be fruitful method 
and helped me secure appointments with high ranking bureaucrats and a former Minister of Interior. However the difficulty of studying human rights in general and torture in particular reflected itself in securing interviews or more precisely keeping them going. We will see in the coming pages how the identity of public officials in Turkey has long been shaped with nationalistic ideologies that saw human rights as a foreign conspiracy. My interviews with officials in Turkey have shown that many individuals in positions of authority have dropped this way of thinking, but there are many who cling to it as well. As a human rights advocate in Turkey put it, "there are archipelagos of reform" in the Turkish bureaucracy (personal communication, June 27, 2007). The question was managing to swim from one small island to the other without being drowned in between. This has been quite a difficult enterprise. In several interviews, I have been chided, even yelled for trying to gather information on efforts to curb torture in Turkey. Yet there were many who welcomed my intrusion into this area. Nevertheless, this has meant that I have not been able to interview all the subjects that I wanted to. One of the pitfalls of the methods that I selected for securing interviews was that I had many informants who were positive towards human rights reform and who wanted to show to the researcher that Turkey was making progress. I have tried to overcome this problem by interviewing two journalists who covered security issues and had links to the police bureaucracy. This has allowed me to gather information on the general situation of the police department.

Another methodological problem concerned the availability of archival sources. Guided by the governmentality perspective, I attempted to find materials such as policy documents, reports written by bureaucrats, and similar devices that were used to intervene in the problem of torture in Turkey. My research indicates that Turkish officials 
did not produce a large corpus of writing on the problem of torture. In some cases, it has not been possible to access to specific reports. This led me to complement the material that reflected governmental thought on the problem of torture and abuse of human rights with material in other sites. In certain cases, the problematization of torture was inscribed in legislation, in statements by politicians. In other cases, professional publications and interviews conducted with officials proved to be fertile sources for finding out the implicit problematization. The documents of the twinning projects also provided a point of entry for capturing governmental thought on the problem of torture.

Although the anti-policies that are explored in this study are deployed in different parts of the world, the dissertation itself focuses on the single case of Turkey. There are several reasons for the choice of Turkey as a case. First, the design of this study necessitates contact and interviews with individuals from various levels of state bureaucracy. While studying a politically controversial subject such as torture, access to informants requires extensive social networks in the field selected by the researcher. Without such connections, it might be difficult to gain the confidence of the informants. Moreover, the conduct of interviews and study of archival data often requires knowledge of the native language. In this regard, selecting my native Turkey as a case reduced the difficulties of field research and increased the opportunities for access to information.

My selection of Turkey was not only a matter of convenience, though. As the 2005 study I cited in note 2 above indicates, human rights abuses in Turkey attracted a great deal of attention from Amnesty International. This attention on Turkey cannot be only explained in terms of the real frequency of human rights abuses committed by the Turkish state. Turkey seems to constitute what human rights activists call a "soft target." 
That is to say, with its relatively active "civil society," availability of physical infrastructure for communication, vibrant journalism, proximity to Europe, and its links with the Western world, it constitutes a target with many "vulnerabilities." For this reason, many human rights activists and organizations focused on Turkey as a case where their work could be fruitful and effective. Therefore, it provides a suitable case for following the formation and implementation of anti-torture policies. In this regard, the problem of torture in Turkey constitutes an interesting case that needs to be studied in depth.

\subsection{Chapter Outline}

This dissertation is organized in terms of themes of anti-torture policies. Each chapter tackles different aspects of the problem by utilizing different but associated conceptual frameworks. In Chapter 2, we start with analyzing the field of human rights activity from the $18^{\text {th }}$ century on. As promised in the introduction, rather than following a teleological development, I look at different modes of advocating human rights, which I call strategies, to survey human rights practices. In this chapter, I posit that there has been a shift from abstract notions of power towards more empirically grounded, researched knowledge of torture and ill treatment. I then look at the League of Nations experience to find out what tools were invented to secure the conduct of states at the international level. This is followed by a discussion of histories of different human rights strategies which form the basis of later chapters.

In Chapter 3, I turn the spotlight on Turkey and its human rights problems. I argue that the notion of human rights has become a significant topic in relations between Turkey and the West from the 1970s on. This part of the dissertation highlights the point 
that there is always a geopolitical context in which the problem of torture emerges. The chapter then proceeds to problematization of Turkey's human rights practices. I show that these problematizations have been dynamic and multiple, coming from international, national and non-governmental actors. The chapter maintains an emphasis on the official approach to allegations of torture and argues that much of the governmental thought on this topic focused on defusing allegations rather than dealing with the problem itself.

Chapter 4 focuses on the police as one of the significant actors in human rights problems in Turkey. In this chapter, the police are not taken as a passive machinery of state but rather, to put it with Bourdieu's terminology, a player in an autonomous field that has its own shifting identities, interests and practices. This chapter looks at the conceptualization of police in different discourses, the attempts at guiding its conduct and then shows that police officers have increasingly developed an autonomous voice and placed themselves as important actors in the process of governance of human rights. This chapter also extends the analytics of strategies developed in Chapter 2 to the Turkish context.

Chapter 5 turns to a specific technology of international government. I provide a genealogy of twinning and look at transfers from development, international supervision, and management into this technology. This is followed by several cases of twinning projects deployed to improve human rights in Turkey. This chapter exemplifies a technicalized instance of human rights strategies.

Overall, I argue that human rights practices to eradicate torture need to be understood in their specificity. Such a research ethos shows that technologies to improve human rights have their own history. The analytics of strategies shows that there have 
been shifts in this history. The focus on the Turkish case, moreover, indicates that antitorture strategies that developed from the $19^{\text {th }}$ century on have all been at work in Turkey, albeit to different extents. The two axes of intervention in this problem (police and the twinning projects) have legitimated themselves through their linkages with these strategies. The case studies also seek to show that human rights practices against torture in Turkey have not only become increasingly technicalized but they have also been implicated in political struggles that are not directly related to the ideal of human rights and dignity of the person. Thus, contrary to the narratives of Europeanization and emancipation, human rights practices have been integrated with the exercise of power. These practices are implicated in the exercise of power in terms of the technologies deployed (supervision, discipline, normalization, etc.), in terms of the conduct that they seek to ensure in twinning projects (embedding police behavior in science, accountability and human rights norms), and in terms of the struggles for capital in the field of policing. Yet this power is different from the notions of power found in the mainstream literatures of comparative politics or international relations. 


\section{CHAPTER 2: ANTI-TORTURE: HISTORY, PROBLEMS AND STRATEGIES}

A recent collection of essays published by the Oxford University Press under the title Torture: A Collection (Levinson, 2004) brings together writers from diverse fields including law, sociology, ethics, politics and journalism. A book prepared as a response to "return of torture" to the Western world, it bundles themes ranging from the $18^{\text {th }}$ century abolition of torture to the ill treatment at the American Naval Base in Guantanamo Bay. The cover of the book shows a medieval torture chair covered with spikes while pages inside the book contain reproductions of several woodcut pictures depicting the painful examination of the accused in early modern Europe. In this way, the editor of the collection draws a continuous line from the judicial torture in $16^{\text {th }}$ century Europe, passing it through the Nazi atrocities and military dictatorships in Latin America and culminating in the "War on Terror" launched following September 11. This history of torture suggests a lineage that connects dispersed events and actions in the past based on a history of cruelty and injustice. No matter in which political and social conjectures torture emerges and reemerges, it always contains, we are told, an element from the

ultimate infamy of Middle Ages. One can come across this version of the history of torture in diverse sites. It can be seen in the conception of the Universal Declaration as a reaction to "medieval methods of torture" (Robinson as cited in Rodley \& Pollard, 2009, p. 18) or mention of "Torture Chambers" in the Latin America (Becket, 1972). Although we are no stranger to this narrative that brings together the Inquisition and international human rights law into the same frame, it is by no means a natural one. 
In this chapter, I problematize this dialectic history of torture and opposition to it. Not infrequently, the history of human rights is written as a process traced back to ancient civilizations in Mesopotamia. It is argued that the kernel of rule of law is found in the Codes of Hammurabi; courageous opposition to arbitrary power can be read even in the ancient mythology. For instance, in her introduction to the Human Rights Reader, Micheline R. Ishay argues that notions like dignity, tolerance, and liberty have deep roots in ancient religions and secular traditions (Ishay, 2007). While Enlightenment is a great leap forward, the influence of Hammurabi, Plato, Cicero and others should be taken into consideration as "early origins of human rights" (Ishay, p. 9). In this way, it becomes possible to frame Hammurabi Codes as a text relating to freedom of speech and civil rights and talk about an accumulation of struggles. This kind of a narrative invokes what French philosopher Miguel Abensour called "the persistence of utopia" (Abensour, 2008, p. 407). This is the utopian spirit of struggle to end domination, exploitation and injustice: a spirit that emerges in different epochs, under different names and reemerges from defeats. Depending on the historical setting the spirit emerges, its vanguards become slaves, peasants or workers, seeking a time and space where their domination is transcended. Any advances in this dialectic of oppression and liberation give birth to new struggles as the present never coincides with the utopia and the search for radical alterity persists.

Problematization of this narrative of human rights lineage can perhaps be seen as an attempt to undermine values of freedom, dignity or equality. However, this is not my intention. In this chapter, I rather seek to look at human rights practices from a genealogical perspective (Foucault, 1977). This perspective eschews looking at the 
history in terms of origins. A genealogical perspective recognizes that names like "human rights" or "torture" are introduced at a certain point in time, giving birth to the domain itself. Sometimes name stays the same while its content changes as the network of meanings that it relies on are transformed. Likewise, what is understood from government, state, citizenship or international politics has been transformed from the $18^{\text {th }}$ to the $21^{\text {st }}$ century, and the human rights practices that refer to these terms need to be investigated in relation to this dynamic network of meanings. In this way, the genealogical perspective asserts that practices, sometimes deemed as eternal, universal and persistent, have a history of their own. Moreover, their transformation is not the evolution of a singular and stable practice from its origin to its final realization. Practices are culturally and historically specific assemblages of disparate elements that are not necessarily related to the "original" idea. Certain anti-torture practices may be associations of speeches, laws, newspapers and imagined publics while others may be networks of experts, monitoring techniques and medical evidences. This is not to deny a basis for human rights struggles. It is rather an effort to unsettle the taken for granted lineage of human rights practices and shed light to relations of power within practices that profess to limit power itself.

This analysis of anti-torture practices foregrounds the inventiveness (Rose, 1999a) of these struggles. Actors who defend values such as liberty, dignity and justice may tell their own story in terms of a thrust taken from the struggles in history. Yet in different times and spaces, they rely on novel logics of struggle, they adopt different methods and intervene in problems in specific ways. They may seek to shame their detractors or seek to persuade them, alternate between legal challenges or mobilization of publics, and cast 
problems as structural issues or unintended consequences. That is to say, human rights struggles are not direct descendants of ages-old struggles. Besides the development and discovery of new techniques, inventiveness of the struggles for human rights can also be seen in the constitution of new subjects and objects by human rights agencies. Human rights work does not have an eternal essence or pedigree but it is a network of shifting mentalities, identities and technologies. It does not constitute the application of an everlasting kernel but is creative, e.g. it links the specific concept of "right" to "humanity" and then declares a specific type of violence as a violation of human rights (Douzinas, 2007).

In terms of international politics, this chapter seeks to show how proliferation of global human rights practices normalized international politics by rendering liberal state practices as the norm to be followed. This normalization deploys technologies of discipline, by adopting them to the global scale, and problematizes illiberal states (Zanotti, 2005). Just as the state was governmentalized by linking different legal, fiscal, military and bureaucratic techniques and practices together and putting them to work toward improving the welfare of domestic populations, disparate techniques of surveillance, reporting, persuasion and guidance are deployed by international authorities to promote liberal practices. This governmentalization of world politics, however, lacks an actor constituted as the center of calculation of strategies and origin of the efforts of implementation. Instead, there are various actors with overlapping or complementary agendas operating in the international sphere and they do not always coordinate their work. 
In what follows, I develop an analytical survey of human rights practices, especially in relation to the problem of torture and ill treatment. In the first section, relying on historical studies, I show how torture was once seen as a dangerous art, even a necessary evil that had to be carried out very carefully. In time, jurists and other thinkers not only emphasized its perils, but they also problematized the practice itself. How this interest in torture was transformed and reworked with techniques of inquiry constitutes the subject matter of the second section. Here, I introduce the concept of the new empirics of torture to differentiate it from previous anti-torture practices. The third section surveys the rescaling of disciplinary and regulatory practices to international politics. This provides the background to the claim in the forth section, that is, human rights strategies in the $20^{\text {th }}$ century were constructed from techniques used in international government. The fifth section focuses on a categorization of different human rights strategies implemented from the $18^{\text {th }}$ century on. It emphasizes that a preventive strategy has been formed in the late 1970s and it became the preferred means for many actors in the field (cf. Evans \& Morgan, 1998).

This chapter uses the analytic of "strategy" to understand the human rights practices. The notion of strategy often invokes the image of a grand plan formed by strategists and implemented according to a certain program. The Foucaultian notions of strategy differ from this usage. The strategic form can be seen as an extension of the genealogical reading of history to the mechanisms of power. Strategies operate on the basis of "dispersed, heteromorphous, localized procedures of power" (Foucault, 1980b, p. 142). Different programs of government, tactics and plans evince a certain implicit strategic logic even though the authors of these elements do not coordinate their actions 
based on a previous consensus. These elements express "more or less coherent and unitary strategic form" (Foucault as cited in Dean, 1994, p. 157). The notion of strategy also evokes a second sense closer to the way it is used in military discourses. This is about acting upon heterogeneous and dispersed processes and guiding them towards an objective. Mitchell Dean argues that these two ambiguous Foucaultian notions of strategy can be merged to arrive at a clearer formulation. Strategies bear upon autonomous programs and practices, but "once constituted, are in turn capable of acting upon the multiple relations to form them into a "chain or system"' (Dean, 1994, p. 157). Often scholars like Micheline R. Ishay (2007) and Paul Gordon Lauren (2003) take ancient legal codes, the French Revolution or the Universal Declaration of Human Rights alternatively as the starting points of human rights in different histories of the subject matter. In analyzing human rights practices as distinct strategies, I contradict this search for a firm and sovereign point in time from which human rights practices begin to flourish and I foreground their contingent character. This chapter focuses on this contingency.

The analytic of strategy has been used before to understand human rights practices. Dezalay and Garth (2006) use this concept in their study on the evolution of the "field of international human rights." Although they do not provide an explicit definition of strategy, they use it to explore the ways in which human rights language is deployed in domestic and international politics to serve other interests. For instance, writing on the human rights movement in the 1970s and 1980s, they suggest that the Ford Foundation's strategy was "mobilizing the academic world and the ideas connected to it in the service of a political project" (p. 246) and bringing together disparate groups to further a cause 
that is common to all. This is contrasted with another strategy used in the 1950s that focused on international law and legal experts. For Dezalay and Garth, the strategies find their expression in organizations. Thus, they talk about the evolution of human rights movement from "elitist moralism to mass organization" (p. 235) and then to professionalism in terms of their paradigmatic organizations, which are, International Commission of Jurists, Amnesty International and Human Rights Watch, respectively. Their account also refers to certain key individuals, through whose biographies and careers in the human rights movement (such as migration from one organization to the other) strategies become traceable.

My use of strategy contains both parallels with and slight differences from Dezalay and Garth in that I look for mentalities, networks and technologies to understand specific strategies of human rights. Thus, although I use certain organizations as examples, I think that it might be misleading to establish absolute links between strategies and organizations and to conclude that strategies define organizations. Strategies of human rights are exchangeable and transferable. Yet, I think that the way Dezalay and Garth focus on the subjects that are privileged in specific strategies is a welcome contribution to the study of human rights practices. This helps us differentiate strategies by looking at the protagonists. Moreover, as they argue, consideration of media organizations, foundations, think-tanks, etc. helps us to go beyond the nebulous concept of "international community." In this way, we can see how the human rights practices take advantage of and rely on other power relations. 


\subsection{Problematization of Torture in the Enlightenment}

Until late in the $18^{\text {th }}$ century, torture was an integral part of the judicial process in most of the Old World. In that period, two main forms of torture existed: Question preparatoire was used to induce confessions from a person whose guilt has not been established yet. Question préalable was applied to the convicted to find out their accomplices and to intensify the punishment (Silverman, 2001, p. 43). Both of these practices came to be employed by the judges after the $13^{\text {th }}$ century when Romancanonical law slowly replaced the earlier procedures of finding out truth. The new Roman criminal procedure required a full proof, that is to say, two witness accounts or a confession. Since witnesses were not easily found and circumstantial evidence was not allowed, judges settled on the question and thus accepted this practice as the "Queen of proofs" (Peters, 1996, p. 40), a highly sought commodity in the legal process that secured the conviction of the accused.

Jurists and thinkers of the time were aware of the problems and the abuse this practice led to, such as the crippling of suspects in the process of questioning or conviction of the innocent. Yet their disapproval of the question typically stopped short of "abolition" and amounted to a demand for better regulation of this act and increased effectiveness in the judicial process (Peters, 1996, p. 72). The preparation of handbooks to regulate torture suggests that this practice was seen as an art that could have negative consequences if practiced incompetently. For instance a $15^{\text {th }}$ century Flemish jurist, Philippe Wielant, writing on the criminal procedure, urged the judges to use a variant of the rack that was both more effective and less dangerous (Rudolph, 1984, p. 162). The criminal code published in 1764 under the orders of Habsburg Empress Maria Theresa 
included detailed descriptions and pictures of torture to instruct the jurists of the realm how to carry out the question correctly (Ruthven, 1978, p. 7). Although retrospective human rights discourses may brand this body of literature and "art" as an expression of evil, at the time, this work was explained in terms of a search for instituting better legal procedures. This dark craft should be improved to accomplish better its objectives of finding the truth, not necessarily to reduce the pain of the suspects.

In the period known as the Enlightenment, there ascended a transnational discourse and activism advocating a legal and penal reform program, which included the "abolition" of judicial torture in its wish list. I would like to emphasize three features of the Enlightenment movement against torture to differentiate it from later efforts. This will be followed by the argument that "rights" framework was not the only intellectually available route to the problematization of torture. Religious discourses provided an alternative way of contesting practices of torture, but this direction was less prevalent than the Enlightenment way of problematization. ${ }^{14}$

The first point is this: the Enlightenment problematization of torture needs to be understood within the context of the rise of the humanitarian idea that human beings have inherent value. Yet this does not mean that the Enlightenment thinkers were against all forms of violence. Let us expand these points. One of the prominent representatives of the idea of human dignity was John Locke. As well known, Locke argued that human beings had their natural rights in the state of nature where the political community did not exist. Unlike other natural rights theorists, Locke defended the inalienable character of basic rights (such as life, liberty and property) by arguing that the social contract that

\footnotetext{
${ }^{14}$ This pertains to the point that problematization of torture from a "human rights" point of view was not self-evident.
} 
formed the political community and justified the authority of the ruler did not diminish the original rights. The contract consisted in the delegation of the enforcement of these rights to the community rather than the rights themselves (Weston, 1984). Thus, Locke was able to argue that despite the existence of social contract there were certain limits to the exercise of sovereignty by the ruler. However, opposition to torture was not simply due to a generalized humanitarianism and compassion for all things human. Indeed, a rise in the sensitivity towards the suffering of the human beings cannot be taken as the sole basis of problematization of torture. What was rising was not a global sensitivity towards all forms of human suffering, but rather towards a certain set of cruel practices. As the historian Thomas Haskell reminds, in the case of slavery, the problematization of human bondage required the constitution of individuals as responsible persons motivated to intervene in an ongoing and specific atrocity (Haskell, 1985). This process of addressing a definite human suffering among others is necessarily selective and relies on techniques -procedures to be followed, what Haskell calls "recipes" (Haskell, 1985, p. 357 )- to be practiced. Rather than the rise of generalized humanitarianism, what happened was the ascent of a new criminological understanding that framed torture as an excessive, useless and counterproductive practice.

Lockean defense of rights, therefore, did not mean that they applied to all members of the community. As Hindess (2004) points out, a crucial move in the history of liberal thought was the distinction introduced within the population between those who have the capacity to govern themselves and those that did not have this capacity. The poor and the unemployed would fall into this latter category of persons lacking the capacity of self-government. Thus, it was possible for Locke to suggest the establishment 
of "working schools" where the state should force the poor "through hard labor, whipping and torture" to be industrious for themselves and the state (Hundert, 1972, p. 5). It is true that the torture Locke mentioned was different from the judicial torture used for extracting confessions, gathering information or torture as punishment. Nevertheless when one considers that the line between the poor and the criminal were thin in Liberal thinking of the era, this distinction between judicial/penal torture and disciplinary torture becomes less meaningful. Liberal problematization of torture within the context of natural rights was accomplished through a hatred of cruelty and, the political form most closely associated with it, tyranny (Luban, 2005, p. 1429). Yet as many students of liberal theory note, the liberal disapproval of cruelty did not amount to a complete rejection of violence and accommodated e.g. violence in wars (Kahn, 2008; Luban, 2005). Therefore, the rejection of torture cannot only be attributed to its violent and cruel character but needs to be linked to the relationship between the torturer and the subject. This relationship, Luban argues, not only deprives the subject of its human dignity but also amounts to a tyrannical control on the body.

Second, the activism against torture in this period was marked by both its reference to public opinion and the porous borders between the philosophical and governmental realms. Throughout the Enlightenment, the main actors in the struggle against torture were not necessarily counterpoised with the state, or the legal institutions. Opposing to torture did not necessarily mean a posture against the state itself. Torture was regarded rather as a problem of being in harmony with the spirit of the times and shedding the weight of tradition on the legal institutions. The public, on the other hand, was constructed as a positive force, which the political authority had to reckon. 
Third, torture came to be seen as an evil act rather than a hazardous legal procedure. It was identified with the Inquisition-like religious intolerance and the responsibility for the lingering of this barbaric custom was attributed to the traditional sections of the society such as the Catholic Church. We will examine these three points in detail below.

First, the issue of the rise of humanitarianism: In this period, the principle of punishment has shifted from one of retaliation to that of "representation" (Foucault, 1979, p. 104). Foucault argues that the leniency in punishment and abolition of torture did not result from compassion or empathy. Absolutist justice worked within a particular system of punishment where crimes were taken as assaults on the Sovereign body, and consequently, punishments were rationalized as personal reactions of the King against the criminal. This system also tolerated petty crimes of the common people and immunities of the nobility. The abolitionists and reformers proposed a more regular system of law based on a different principle of punishment. Power to punish would be delimited but at the same time, it would be extended to the entire social body without exception. The spectacle of punishment was no more desirable as it legitimized cruelty and invited violent insurrection. The Philosophes proposed to establish a firmer and more logical relationship between the crime and punishment (Foucault, 1979). The objective of the representative principle of punishment was deterrence of crimes and the education of the (potential) criminal by way of example. Punishment should be visible so that everyone could understand the rational link between it and the crime, and draw her lessons. The "secret and private carnage" of torture in dungeons could not engrave the suffering of punishment in the minds of the potential criminals. Moreover, it was believed that, the 
crippling effects of torture on the body would make it harder for the criminals to become normalized members of the society (Beccaria, 1764/2008, p. 33).

The second point that I brought out in the anti-torture activity was its public nature and its links to official authorities. The analysis here needs to attend to the ways the public was constructed, rather than assuming a universal public sphere with an antistatist essence. Before going further, a discussion of the Habermasian concept of "public sphere" is in order. The German philosopher argued that in the $18^{\text {th }}$ century, there emerged a bourgeois public sphere where members of the civil society came together, on an equal footing, to discuss issues relevant to the public. This unprecedented development came through "people's public use of their reason" (Habermas, 1993, p. 27) in salons, reading rooms and other venues where individuals could convene and in a sense challenge the state's encroachment on all aspects of society. Through discussions and circulation of books, journals and other print media, the bourgeoisie formed a sphere that was different from both the intimate sphere of family and the realm of state. Habermas attributes an anti-state essence to this sphere. To him, reducing the regulation of the mercantilist state on the economy was already in the interest of the bourgeoisie but public sphere deliberations helped develop an ideological consciousness in this class. On the basis of this awareness, civil society demanded a predictable legal system and a mechanism of political decision making based on public opinion (Habermas, 1993, p. 54).

In Habermasian terms, the problematization of torture in the $18^{\text {th }}$ century can be seen as part of this autonomous development of the civil society. As the bourgeoisie became more powerful against the state, it challenged sovereign intervention in what 
represented a very private sphere, the body. Intellectuals of the civil society, like Beccaria, Voltaire or others appealed to the public to delimit state intervention. They utilized the print media to mobilize the public, which was already there brewing against oppression. However, this sort of a conception of the rise of opposition to torture can be misleading in that it presupposes the existence of "the public" and underestimates the work of the Philosophes. In such controversies, before the emergence of a contesting public, the issue itself needs to emerge. Before the public tackled the issue of torture, Philosophes had to represent it in their books, journals, and speeches. By representing this issue they also made possible the formation of a sensitized public concerned about it. There may be many ways of making and representing issues -"making things public" as Latour (2005) calls it- and various ways of constituting diverse publics. An issue may be made public in ways that addressed local, national or international audiences (Marres, 2007). A human rights NGO may represent the occurrences of torture in terms of quantities and map them according to regions of the world. In this way, it simplifies the data and establishes relations between acts and spaces, thus constituting regional publics. Opposition to torture à la Voltaire, on the other hand, produces a different picture. It makes possible the contribution of witness statements or lived experiences and creates a different sort of public as a relation of accountability (see Asdal, 2008).

In order to understand the public element in this period, one needs to look at several prominent events and figures. One of the representative events of the times was the "Calas affair" that was sparked by an incident in Toulouse in 1762. To Voltaire, this was the quintessential example of Infamy, or the bigotry and intolerance of institutional Catholicism. This affair was a travesty of justice, where Jean Calas, a Protestant cloth 
merchant, was accused of killing his son to prevent his conversion to Roman Catholicism. He was convicted, subjected to question préalable to get him confess his accomplices and sentenced to death by breaking on the wheel. Only three years later he would be acquitted (Silverman, 2001, p. 157-159). Seeing this issue as a perfect example of religious intolerance, Voltaire turned this event into a cause célèbre. Here the judicial arm of the absolutist state was meddling with religious life of a person, a sphere that had to be free from state interference. Voltaire was displacing this legal case from the familiar and regular sphere of public authority and placing it into an autonomous sphere of civil society. Rather than asserting the "already existing" right of religious freedom, what Voltaire initially did was drawing boundaries between the civil society and the state. Echoing many modern tactics of struggle against torture, he sought to find out more about the case. He interviewed one of the children of Mr. Calas, and wrote to Toulouse asking for information. He raised money for the family while also writing a memoire (a personal account of the case), and several essays which criticized the legal system, urging religious toleration. His essays were published in England, Scotland, Ireland and United States. As the historian Lisa Silverman puts it "the case provided the first significant occasion for public criticism of torture" (2001, p. 159).

Voltaire rendered the public as a conscientious judge in his essay on tolerance. Writing on the case and the appeal process at the Council, he said: "Paris and the whole of Europe were moved with pity, and demanded justice for the unfortunate woman [Jean Calas' widow]. The verdict was given by the public long before it was signed by the Council" (Voltaire, 1912, p. 12). His struggle was characterized by an appeal to values such as justice and toleration. Voltaire sought to construct a public with careful use of 
techniques such as proclamations, pamphlets, memoires, by addressing salons and cafes where intellectuals and the concerned bourgeois citizens came together.

In this rendering of torture as cruelty and bodily pain, state was not seen as directly accountable for the injustice but it was certainly responsible in terms of abolishing the practice and developing toleration. He saw legal reform as the solution to the problems of judicial system. That Voltaire's criticisms were not directed at the state is manifested in various ways in his writings. For instance, in his writings on the Calas affair, he mentions the reasonable judges and lawyers who opposed to the injustice done to the Calas family (Voltaire, 1912, p. 7). One should also note Voltaire's suggestion about the political capital: "at Paris reason dominates fanaticism" (Voltaire, p. 11). When taken in relation with his efforts to influence the ruling class, this nod towards Paris becomes more meaningful.

To see the links between anti-torture activity in this period and the official authorities clearly, we need to turn to the work of Beccaria and Josef von Sonnenfels. In this "age of philosophy," the publication of the tract On Crimes and Punishments (published anonymously in 1764) by the Milanese writer Cesare Beccaria was a notable event. In his book, Beccaria attacked the legal system, which was full of irregularities, and advocated a utilitarian and rational justice system. More concretely, he supported a proportionality of crimes and punishments, abolition of torture and death penalty except in times of national emergency, and a public judicial system. Beccaria, like Voltaire, had connections to the imperial capitals around Europe; and like other intellectuals of his time, his most powerful hope for seeing his ideas implemented was their adoption by rulers (Beales, 2005). Despite the attacks of the Vatican, Beccaria's proposals were 
adopted by the Catherine II of Russia. She had ordered the preparation of the Nakaz (Great Instruction) which included the general principles of the legal system and on her admission, copied many parts of Beccaria's book verbatim (Cizova, 1962). The antitorture strategy of the time was bent on making torture a public issue, exposing it as a matter that the public had a stake in. It took the form of a "pamphlet and pulpit warfare" (Beales, 2005, p. 14) and sought to act upon the legal system. At the same time, these "philosopher-activists" (Loft, 1992, p. 129) had solid relations with the enlightened despots of their time, they corresponded with them, made their counsels available and also visited them to discuss legal and other reforms in the hope of seeing them implemented.

The Figure 2.1 below nicely captures the attitude of the Philosophes towards excessive punishment, including torture. In this German edition of Beccaria's On Crimes and Punishments we see a picture based on the author's sketch (Rare Books Blog, 2011). Here, the Lady Justice is presented three severed heads by the executioner. Rejecting these in disgust, she looks to the other way leading our eyes to the agricultural and industrial tools and a scale on the bottom right corner. The message is clear: A balanced punishment that seeks to train the criminal and render him/her useful for the society. The picture also gives the message that adoption of a rational criminal justice system as opposed to excessive punishment is a matter of choice. The posture of Lady Justice, saying "No" to the executioner and showing us the alternative, I think, relays this Enlightenment idea. This is similar to the Enlightenment idea that the solution for torture is its rejection and its abolition. The only action the moderns need to make, it was thought, was to make the right choice between Infamy and Enlightenment. 
Figure 2.1 Left, Lady Justice represented in German edition of Beccaria's book On

Crimes and Punishments. Courtesy Rare Book Collection, Lillian Goldman Law Library, Yale Law School. 
Another noted figure in this period was Josef von Sonnenfels (1732-1817) who became the first professor of Police and Cameral Sciences at the University of Vienna in 1763. While serving the monarchy in the capacity as a professor and consultant on police sciences, judicial and economic issues, von Sonnenfels started a campaign against the Queen Maria Theresa's draft criminal code prepared in 1768-69. He criticized the code in his writings and lectures, focusing on torture and capital punishment. The Viennese Medicine School faculty also petitioned the monarch against "too severe torture" in 1773 (Beales, 2005, p. 10). Finally, with the support of the provincial administrators and state council, Maria Theresa ordered the abolition of torture in 1776. Von Sonnenfels explicitly justified his opposition to the code on the basis of "state welfare" and not on humanitarian grounds (Kann, 1960, p. 185). He appealed to humanitarian notions in his later attacks on the criminal code, but his opposition to frequent use of torture and capital punishment needs to be understood within the context of the reason of state. This mentality of rule emerged in the $16^{\text {th }}$ century, aiming to increase the strength of the state not necessarily through better protection of the territories (sovereignty) or accumulation of more financial resources (mercantilism) but through improving the welfare of the population (Gordon, 1991). The general population and the individuals should be guided towards a productive life that would eventually translate into strength of the state. In this context, putting men to productive work became more appropriate than putting them to the rack or the gallows.

These were the early instances of an anti-torture strategy, which appealed on the one hand to the monarchs and tried to convince them with cameralist arguments about the welfare of the state and on the other to the humanitarian and compassionate feelings of 
the "public opinion." This strategy was bent on transforming the mechanisms of rule by rendering the public opinion a force to be reckoned with by the absolute monarchs. The "policy-making" processes should not be limited to the palace, the feelings and ideas of the public should be taken into consideration along with political, legal and religious authorities to arrive at decisions (see Latour, 2005). Cameralists' coalition with the rulers was required for the struggle against barbarian practice of torture to succeed. The monarchs were in a peculiar situation. They boasted of their allegiance to values of the Enlightenment but were caught between progressive "public opinion" and a religious establishment wary of eradication of its traditional privileges and ideological prestige in society (Beales, 2005). The public oriented strategy and deployment of memoires, causes célèbres, petitions, essays, and pamphlets were meant to create sensitive and involved publics and find a basis for reform in "public opinion."

Up to now, we have seen that anti-torture policies developed mainly as a specific mode of humanitarianism, motivated by a search for a better legal system. Second, we have seen that the relations between advocates of rights and their interlocutors were not necessarily antagonistic. The third aspect of difference from the earlier thinking on torture was the way torture was perceived as a societal institution. The advocates of Enlightenment, philosophers and cameralists captured torture as a problem stemming from ignorance, error, passion and fanaticism (Beccaria, 1764/2008; Voltaire, 1912, p. 1) all of which are opposed to the reason on which the legal system of the future should be based. Torture was a consequence of sentimental search for revenge or based on "ancient and atrocious customs" (Voltaire, 1994). What the reformers should do was to listen to the nature and apply its lessons to justice. "Pleasure and pain are the driving forces of 
sentient beings" (Beccaria, p. 19) so torture could not be a good way of arriving truth because it distorts the normal functioning of the reason and leads the victim to "choose the shortest route to relieve his pain momentarily" (Beccaria, p. 34).

The Philosophes attributed this problem to ancient legislation. The name of the struggle was abolition rather than prevention, eradication or criminalization of torture. The advocates of abolition seemed to be content with the adoption of just legislation, exclusion of torture from law books, and its prohibition. They hardly foresaw a problem of implementation or any difficulty in suppressing torture once it was abolished legally. For instance, Voltaire felt safe to say in $\mathbf{1 7 7 8}$ that torture was abolished in much of Europe including Prussia and Russia (Voltaire, 1778, p. 103) although one can safely conclude that legal prohibition was not immediately put into practice. What the reform wanted to address, then, was not primarily the implementation of laws on the ground but rather the harmonization of laws with the principles of reason. The abolitionists did not mention a difference between the law on books and "actual law." It is also possible to assert, that the reformers did not see torture as a specific crime, or at least did not treat it such. This is evident in the way Beccaria conceptualized crime and the proper means to prevent it. Crimes could not be stopped with "eloquence, rhetoric or truth" (Beccaria, 1764/2008, p. 11). They provided the criminal with a certain advantage, and prevention could function by erecting an obstacle (punishment) which in the mind of the potential criminal cancelled the advantage of crime. Yet, he entertained no such scheme for torture. Torture, was a practice that occurred because of irrationality and tradition, which could be eradicated when its uselessness was proven. Yet, it was sustained due to the interests of the traditional sections of society. 
This treatment of torture as non-crime was also found in the legal system of Ottoman Turkey, at least until the modernization currents in the $19^{\text {th }}$ century. Ottoman historian Ahmet Mumcu (2007) writes that Ottomans used the word zulüm (cruelty) to refer to ill treatment inflicted on the population by state agents. Etymologically speaking, the Arabic word zulüm meant misplacement, not giving oneself her due. In Islamic jurisprudence, zulüm was despised, and considered as an act that would be punished in the afterlife. Nevertheless, Mumcu argues, the Islamic law did not provide a definition or categorization of zulüm and hence did not consider it as a crime. Moreover, victims of such injustice were encouraged to forgive wrongdoers. As a state founded on the Islamic notion of justice, Ottoman Empire's ruling class despised this sort of injustice inflicted on the flock by its own agents whether they were high-ranking pashas or simple local judges. Due to the influence of the Islamic jurisprudence on the Ottoman legal system, however, zulüm was not considered as a crime in itself. This indeterminacy of the category of state injustice and the lack of rule of law meant that the punishment of such acts was irregular. The punishment for wrongdoers ranged from capital punishment to simple admonition, depending on not only the degree of injustice but also the opinion of the justice-giver.

The Philosophes stressed two forces that define the conduct of persons: habit and utility. The conduct of the individual was either rational, that is, based on the pleasure vs. pain principle or it was based on customs. The latter includes all that is irrational, superstitious, and ancient. Often the Philosophes analyzed the problem of torture within this theory of action. Voltaire, Beccaria and others were deeply convinced that the practice of torture and indeed other forms of cruelty were in this second category. Thus, 
they entertained a hypothetical notion of torture. While they reacted to real world events and gathered information about instances of torture, as seen in the case of Calas affair, this was intended to confirm a general scheme of analysis that was already given. Their writings on torture served to confirm that custom still ruled the behavior of those in a position to distribute justice, something they already assumed in their studies. Unlike today's advocates of human rights, abolitionists did not see any need to investigate the reasons, context, politics, and psychology of torture or measure its frequency but relied on philosophical precepts to capture it. Neither European nor Ottoman thought contains a criminology of torture. They already knew the causes and sought an ideological triumph over this cruelty. This is not to argue that today's human rights activist always command a deep and rich knowledge of incidents of torture. There may be instances where such advocates lack knowledge of context or history and thus remain superficial. Nevertheless, the value of first-hand information, knowledge of history and local conditions, and research on site remains a standard and is not questioned by contemporary human rights advocates.

Up to now, I have emphasized the historical and contingent nature of the conception of torture in the Enlightenment period. In order to underline this point, we also need to briefly look at post-Enlightenment period before going on to the developments in the $19^{\text {th }}$ century. In this interval, we can detect a shift in the theory of rights from natural rights towards a new framework. The 1789 Declaration of the Rights of Man and of the Citizen after the French Revolution was one of the steps towards the replacement of natural rights framework of the Enlightenment with "the Rights of Man" or the human rights framework. Similar to the Lockean theory, the second article of the 
declaration rejected torture by recognizing the rights of "liberty, property, security, and resistance to oppression" (as cited in Ishay, 2007, p. 490). The justification for natural rights was the natural law of the universe which was prior to the community. Therefore the natural rights were in a sense negative rights that sought the preserve the original rights (Pagden, 2003, p. 189). The human rights notion after the French Revolution, however, comprised of rights that were proclaimed by the national community. They belonged to the humans due to their natural dignity but still they were exercised within the political community comprised of citizens and did not apply to the international life (Pagden, 2003). The implication is that torture of the humans was problematical due to the violation of the rights of the citizen, rights which rendered him sovereign.

To reiterate the historical character of the abolitionist movement we also need to look at the religious discourse, which we have mentioned as the main alternative to a discourse of natural rights. This is necessary to recognize that the human rights discourse, and anti-torture strategies in particular, is one amongst the many avenues possible to defend liberty and oppose torture. The human rights discourse established itself as the main territory of justification of opposition to torture from the $18^{\text {th }}$ century on at the expense of other discourses (cf. Asad, 1996, pp. 1104-1105). In theological discourses, the human dignity was justified not on the basis of an original condition but on the basis of the fact that human beings were created by God. This understanding can be seen in the debates on slavery in the $17^{\text {th }}$ century Portuguese colonies of Brazil. ${ }^{15}$ One prominent

\footnotetext{
${ }^{15}$ According to Eisenberg (2003) the two protagonists of colonization in this period were the Jesuit order who sought to spread Christianity in the new world and the settlers looking to grow sugar through the use of indigenous labor. The settlers were often in dire need of manpower and abducted native men from the inner territory. This practice was disapproved by the Jesuits. Settlers often argued that slaves were "bought" from other indigenous chiefs who held them captive or Indians themselves sold their liberty. Therefore the
} 
Portuguese Jesuit missionary, Antonio Vieira, whose life story was eloquently told in the movie Palavra e Utopia by Manoel de Oliviera, opposed this practice of entrusting slaves to the settlers. In one his sermons Vieira charged against the settlers in his audience arguing that what they did was enslavement, exactly the same thing that the Egyptian Pharaoh did to Israelites. He argued that the epidemics and the attacks by Dutch on Portuguese colonies were the wrath of God who was "favorable to the cause of liberty" (Vieira, 1653/1966, p. 84). Later, Vieira opposed the slavery of native population by tackling the theory that the natives were free to sell their liberty. In his later sermons, Vieira argued that voluntary slavery that the settlers defended was not possible because even if a native owned own his liberty and could sell it he did not own his body. Lifetime slavery was not justifiable since it amounted to the selling of the body, rather than the liberty (Eisenberg, 2003, p. 93).

Besides unjust slavery, judicial torture has also been condemned by those speaking in the name of Jewish and Islamic theology. Similar to the argument against slavery, Edward Feld, a Rabbi, writes that torture is unjustified because of the sacredness of human life and body which were created by God in His own image (Feld, 2006). There were also prominent Muslim jurists (such as Ibn Hazm in the $11^{\text {th }}$ century and alGhazzali in $12^{\text {th }}$ century) who argued that torture, or more specifically, violence against suspected criminals to obtain confessions, was not acceptable to the Islamic religion (Reza, 2007, p. 24). Similar to the Judaic reasoning, torture is banned because the God has created human beings and their dignity and honor should be respected at least out of respect to its creator (Hussein, 2003).

settlers had "the right to extract labor or tribute from the Indians for the rest of their lives" (Eisenberg, p. 91) in return for protection and religious education. 
Philosophes and scholars' anti-torture strategy developed at a time when governing less and providing liberty to subjects was not yet the norm in Europe. Thus, they put much effort in enrolling other social and political actors in their agendas, and establishing a consensus against torture and corporal punishments. The way to build this consensus was appealing to reason and the sentiment and consequently their work included much emphasis on the feelings of individual victims and idiosyncratic details that made the narrative more gripping (Ferret, 2009). As the torture became more and more an unthinkable practice, building consensus against it left its place to more urgent tasks. Anti-torture attitudes became "governmentalized," procedures of governing the state were applied to this problem. This meant that the knowledges such as the science of administration, science of state (statistics) would be deployed against torture. A more empirical truth about torture emerged. Its reasons were understood in a less philosophical way, its story was told with less reference to real persons and sentiments. This was torture understood as an administrative problem: a problem that had to be officially studied and known before becoming a target of intervention. The next section surveys this change in the concept of torture.

\subsection{The New Empirics of Torture}

In his lecture entitled "Truth and Judicial Forms," Foucault (2000, pp. 1-89) pointed out that each society has its own regime of truth. He argued that it is possible to talk about three distinct methods of finding truth, each corresponding to a different relationship between knowledge and power. These methods were the test, the inquiry and the examination. The test was essentially a struggle between two forces, played out within the framework of rules of finding out truth. Evidence was absent in this mode of 
knowledge, and third parties were involved only to verify that the contest conformed to the rules. Well-known examples of test were the ones used in the "witch hunts" of medieval Europe where eccentric rules of truth finding were used. For instance, in order to understand whether a person practiced witchcraft she was immersed in the river with her hands tied. If she floated, this was taken as a proof that she practiced witchcraft as her floating indicated the rejection of water. She was cleared of the charges if she sank in the water. Here the truth resided with the deity, which spoke through the force of the water. This followed from an understanding that knowledge and power were united in the same authority; one who had the power also had the knowledge. Another way of establishing truth was the inquiry method, deployed by the Church in Inquisition and by secular authorities at least from the $11^{\text {th }}$ century on. The inquiry form of truth was used when those in power recognized that there is a terrain or an area of activity that is not exactly known to them but that they need to discover it in order to exercise power. In such a case, knowledgeable people, experts, persons on whose judgments ruler can rely on are brought together and led to investigate. The object of investigation could be a crime as in the Inquisition, or the size and property of the lands of country, or, as in our case, accusations and allegations of abuse and torture. In its typical form of criminal inquiry, Foucault pointed out, what differentiated this procedure from the earlier ways was the intervention of a third party associated with the political or social authority and the fact that final resolution was arrived in the name of this authority. It was radically different from the arbitration procedure, where parties resorted to a referee only if they wished to. In inquiry, the third party was intervening in the name of a higher good to establish justice. The examination procedure, on the other hand, was connected with disciplinary 
settings such as the prison, military and the school. This method was interested in truth insofar as it helped oversee the conduct of a person according to a norm. Where the inquiry was operated to find out past events, the examination was used for surveillance (Foucault, 2000; Pavlich, 2010).

As a procedure of finding out truth, the inquiry differs from both the archaic test and the disciplinary examination. The inquiry procedure was not limited to the courtroom but was adapted to various contexts. Royal Commissions of Inquiry widely used in the UK or ex-British colonies of Canada, New Zealand and Australia for political, social and legal questions (Gilligan, 2002) or Truth Commissions established to recover the memory of periods of conflict (Posel, 2008) can be seen as versions of truth finding via inquiry. Thus, the inquiry can be seen as a diagram of power, a mobile mechanism, not limited to its specific and local uses but is flexibly applied across different sites.

In the $19^{\text {th }}$ century one finds that several instances of the inquiry procedure being applied to the question of torture and abuse of authority as a problem for governments. Deployment of the inquiry method to instances of torture has several implications. First, this signals the interest of the officialdom in this question, an effect of the liberalizing mentality of rule, which required a state upholding the bodily integrity of its inhabitants. Second, it introduces what we can call a "will to facts," an acceptance of the lack of sufficient knowledge and the objective of finding it out. This is significant because it could start a drift towards a statistics of torture or a record of state's own crimes and failures (which can be seen in the cases below). This also indicates an awareness that legislation is not sufficient to intervene in a domain comprised of multiple actors and interests. 
One of the infamous cases of the deployment of inquiry is found in the context of allegations of torture in Madras Presidency (Tamil Nadu) in colonial India. From 1820s on, reports were coming to the local government about instances of torture. In 1826, the Court of Directors instructed the Madras government to investigate the allegations of torture in revenue collection process and a British Parliamentary Committee heard the allegations in 1832 (Peers, 1991, p. 33). As time passed by the allegations showed no signs of diminishing. The sensitiveness of some MPs towards the spoiling effects of imperialism on Britain proper and a bid to put the East India Company in a difficult position kept the item high on the agenda of parliament. Intense political debates eventually led to the founding of a commission of inquiry ("Commission for the Investigation of the Alleged Cases of Torture at Madras") to find out what was going on in this region. The Commission was headed by a Liberal lawyer who was a member of the India Reform Society and a local newspaper editor (Ruthven, 1978, p. 183-184).

In the previous pages we have seen that Philosophes of 1760s had little, if any, doubt that torture and cruelty in the judicial process was due to the lingering of archaic customs sustained by the traditional privileges. Unlike Voltaire and Beccaria a century before, the British officials were not exactly certain about the causes, dynamics, methods and the extent of torture and abuse of authority in India. They first sought to render the situation on the ground "readable"16 to the imperial center and started to exercise their power by asking questions. In the inquiry, several new objects, subjects and forces that made torture and abuse possible in the Madras region were discovered. Their visibility enabled the British government to constitute them as objects and subjects and act upon

\footnotetext{
${ }^{16}$ I borrowed the term from Zanotti (2005, p. 465).
} 
them. The Enlightenment Philosophes had thought that the information they gathered were sufficient to make accusations and offer abolition of torture as the solution. Moreover, abolition did not remain as an Enlightenment proposal, it was the solution condoned by absolute monarchies, too. Modern state, on the other hand, increasingly understood government in terms of the autonomy of the governed (Dean, 1999, p. 15). Within liberal mentalities of government, administrative personnel were also seen as autonomous subjects (Osborne, 1994). Autonomous bureaucratic subjects could not be governed solely by sovereign commands of the ruler. Autonomy of this group of people, their unpredictability, required the procedure of inquiry because the latter provided the knowledge to act upon situations of torture. Philosophical truths of the Enlightenment concerning human behavior, such as the interplay of customs, sentiments and reason, were not sufficient in governing the bureaucratic personae.

The legal sanctioning of torture, supporters and perpetrators of it, its victims, instruments and the public were already known as elements by the abolitionists. ${ }^{17}$ These subjects existed in the vocabulary of those who worked to expose the torture in Madras, too. So what was novel in the Madras scandal and what did the "Report of the Commission for the Investigation of the Alleged Cases of Torture at Madras" make visible? To begin with, the old model of abolition or prohibition of torture was no more satisfactory. In the correspondence between government and the commission, the Government in Council expressed fury at the extent of torture:

The use of torture... is of course a criminal offense and punishable... but it is not sufficient that such acts should be merely entered in the category of crimes but

\footnotetext{
${ }^{17}$ For instance, in the Calas affair the fact that religious affiliation (Protestant in Catholic country) and vulnerable social standing of the victim was seen as a factor that made cruel punishment more probable.
} 
their general prevalence, in spite of legal prohibition, calls for an immediate and sifting investigation and for eventual measures for their suppression. (House of Commons, 1854 , p. 50)

Here the government conceded that the simple acts of criminalization and penalty were not useful for dealing with the problem at hand. In the case of such frequency of torture, other measures were required. Indeed this brings to light why a commission of inquiry was preferred. As a method, it went beyond a limited criminal investigation. Unlike the criminal court procedure, it did not seek to mete out punishments on the basis of an isolated case and find individual culprits. The technique of inquiry and reporting made possible to investigate all the cases not only in their individuality and in their specificity but also more significantly in their generality, adding into picture the relations between cases, their reoccurrence, and their spatiality. The criminal justice system included the assumption that punishment of a crime is the solution to it and prevents its repetition. The authors of the inquiry, however, did not pretend that they had all the necessary answers and focused on finding ways to prevent further occurrences. The report thus justified the suggestions it made on the basis of the research undertaken. In the end, the report suggested a system where punishment was articulated to a system of civilizing, regulating and leading the native officers in order to suppress torture. ${ }^{18}$

One of the significant implications of the report was the gap between the state and the native police officers, that is to say, the inability of the Europeans to exercise

\footnotetext{
${ }^{18}$ In the Madras case, the mandate of the commission of inquiry did not ask "what should the government do" and there was no bullet point list of recommendations in the report itself. Yet the commissioners timidly made some "respectful suggestions to the Government... rather than as an expression of any decided conviction." These suggestions themselves were a minor and humble novelty in the practice of reporting results of inquiry.
} 
effective control over the native officers and hence failure in preventing or punishing torturers. Torture was completely "startling to European ears and abhorrent to European morality" (House of Commons, 1854, p. 40) so there was no question that they were not the perpetrators of this cruelty. Cases of torture, argued the report, attested to the lack of control of the administrative and judicial processes by the European officers. The native officers refrained from torture and ill treatment in or near stations where there were Europeans (p. 35). By utilizing tables, commissioners showed that only a few European officers were responsible for vast amounts of land and big populations. For instance, a table on page 37 of the report listed the territories, their extent in square miles, their population and the number of European officers responsible for each territory. The table showed that in some districts, there was only one European officer per 400,000 people, thus making it extremely difficult for Europeans to monitor ill treatment. Europeans were also not able to supervise the judicial system sufficiently: "It is obvious that much cruelty may be practiced... without any mark being left on the person... Although the law provides that the police shall forward prisoners and witnesses within 48 hours of apprehension, no rule is more constantly broken" (p. 35). Those who blame European officials for not investigating all the complaints were "ignorant of or forget the immense size of" the regions and the small number of Europeans employed (p. 37). Differentiation of the state, the high bureaucracy, its ideals, morals and norms on the one hand and the reality on the ground, was a way of exonerating the state, or shifting the blame to the colonized (Rao, 2001). In this context, it is possible to highlight a continuity from the Enlightenment period. The $18^{\text {th }}$ century change in the outlook towards torture was accompanied by new understandings of the Western individual. As Lynn Hunt (2004) 
argues, the "individuation of bodies" in this period (p. 43), epitomized in the rise of practices such as personal portraiture, private rooms in houses, personal hygiene, valorization of inner experiences in novels, constructed the person as autonomous and inviolable. This status of bodies, Hunt argues, was limited to the Western subject. For instance, Brissot, who later became one of the leading figures of the French Revolution, opposed corporal punishment arguing that it represented the "atrocity of cannibals" (as cited in Hunt, p. 50). Another penal reformist, Servan, pointed out that such punishments were "barely worthy of finding an asylum with savage peoples" (as cited in Hunt, p. $51) .{ }^{19}$ But apart from this "ideological" function, discovery of the lack of effective European control opened up a new space of intervention and called for organizational and criminal procedure reform in India while defining the condition as a problem of what Rose and Miller (1992) would call "governing at a distance."

Throughout the report, the native character of the police loomed large as a domain that had to be regulated. The locals were employed as police officers, and were given almost no training. It was thought that the native persons already had certain traits before becoming police officers: They were cruel, corrupt, ignorant, and wont to violence. And then there were circumstances: They were underpaid, without moral restraint or selfrespect due to lack of education (House of Commons, p. 40). However, in terms of preventing further occurrences of torture, the situation was not hopeless: "spread of education, effective communications in the region, and increased intercourse of mind to mind" would affect the native character. The report also approvingly quotes the letter of a

\footnotetext{
${ }^{19}$ The individuation of bodies applied principally to male citizens. For instance, after the French Revolution, the punishment of iron collar was abolished, but could be inflicted on women or slaves. In the United States, the abolition of cruel punishment did not necessarily apply to slaves (Hunt, 2004).
} 
court clerk who says that the police should also be given a handsome pay (p. 41). Had the native officers have higher standards of living, it was thought, their corruption could be stopped and their behavior towards other natives rendered more humane.

Nevertheless, the authors of the report were aware that this mode of acting upon the conduct of natives would be too gradual and general. Rapid precautions were needed for this growing problem. Moreover, there were other rather non-native reasons for the corruption of the affairs of Madras Presidency. Tackling these would bring more immediate and effective solutions to the issue. By shaping the legal field of action of the native officers, the problem of torture could be repressed. The problems were, "tedious and circuitous procedure" (House of Commons, 1854, p. 38) of law which referred the cases of torture to the civil magistrate rather than the criminal courts. This made it easier for the abusers to escape justice. The regulations should be overhauled to bring "detective and preventive police science" of Europe to India (p. 43) and this would lead the native officers to stop relying on confessions and learn to utilize other sorts of evidence. The Report also consistently opposed the concentration of too much authority in the hands of native officers as one of the reasons of torture. The natives were given both the function of revenue collection and police. This could be solved with the familiar formula of separation of conflicting powers, a hallmark of good government in Britain (Rao, 2001). Native officers could be reorganized as specialized and separate agencies of police and tax collection. European supervisors and intelligent superintendents would be both effective checks on abuses and means to punish those who insist on torturing Indian subjects. 
The differences between the Enlightenment response and empirical response to torture are quite apparent. The latter brought into play many variable and elements that were hardly visible in the Enlightenment efforts against torture. Spatiality of the field, the differentiation between bureaucrats and low ranking officers, the "civilizational" distance were all elements pronounced by the report of the House of Commons. The confidence of the philosphes in the causes of torture was hardly found in the report. Moreover, the British inquiry saw legal mechanisms as one instrument among many, and not necessarily the favorite.

These developments not only showed that a nascent anti-policy of torture was emerging but also that the commission of inquiry was being slowly established as one of the principal mechanisms of the official reaction to allegations of torture and abuse of authority. This mode of asking will again be deployed in other places and times. In the eyes of the officials concerned, it was an efficient means to know local and distant circumstances. For instance, a scandal similar to the Madras case emerged in France in November 1879. Several newspapers reported that the transportés banished to French penal colony of New Caledonia ${ }^{20}$ were being mistreated by the guards on the island. The Communards who received an amnesty and returned back to France were alleging that the guards were resorting to "frequent whippings and regular use of thumb screws" (Toth, 2003 , p. 50) on those banished to the island. In response to the allegations, the French parliament formed a commission of inquiry in January 1880. It was thought that this

\footnotetext{
${ }^{20}$ In 1864, France decided to banish criminals to New Caledonia, an island in South Pacific. Banishment and deportation were already in use at the time of French Revolution. This practice was included in the Napoleonic Code of 1810. For a Foucaultian reading of the penal colony in the history of punishment see Redfield (2005). British penal colonies in Australia constitute the paradigmatic example of this practice. For a history of penal colony in Australia see Hughes (1986).
} 
method afforded an objective way of finding out the truth since the inquiry was not undertaken by officials who were directly involved and implicated in the events. Investigations of the situation in New Caledonia led to the conclusion that it was not sufficient to order the guards to behave better towards the prisoners. The officials reasoned that reforming the conduct of the guards required acting on the circumstances of the guards. This could be accomplished by improving their standard of living and shifting the system of punishment from corporal to non-corporal (Toth, 2003). In line with this it was decided that guards would receive better pay, better housing, provision of health services and bodily punishment like whipping would be replaced by punishments like reduction in daily ration or confinement to cell.

Commissions of inquiry developed as techniques that constituted states or similar authorities as actors that were different from social actors, able to find the truth through rational means and aloof from narrow societal interests. Commissions brought together both experts and representatives of diverse interests, and through its formal procedures of reasonable debate and use of evidence they discovered the truth (Ashforth, 1990). The method of inquiry emphasized the need for expertise as the means to solve problems and thus connects state with scientific knowledges and practices. Crises such as torture scandals puts into question state legitimacy and governmental knowledges. The Madras scandal shook the legitimacy of British rule and the New Caledonia scandal called into question the administrative knowledge concerning penal colonies. In both situations the state legitimacy and its knowledges were maintained with reconstruction of "public 
accountability, embodying openness, disinterestedness, objectivity, and by summoning 'expert' evidence” (Ashenden, 1996, p. 67). ${ }^{21}$

The new notion of "empirical torture" emerged through these methods of truth speaking where investigation by experts had to precede its eradication. In the $19^{\text {th }}$ century and later, we witness a new mode of anti-torture strategy unlike the strategy against abstract Enlightenment notion of torture. The distinction that I propose here is in some ways similar to what Richard A. Wilson (2009) suggested in his study on different modes of representing human rights violations arguing that we can differentiate "narratives" and "reports" of human rights. Reports have a tendency to publicize events in a legal language, as this is the idiom of the state. While writing reports, human rights organizations assemble contradictory pieces of information to produce a coherent artifact with a "single integrated plot" (Wilson, p. 213) that underlines state responsibility. Unlike the narratives of bystanders and victims, which provide thick descriptions and are full of details, reports seek to present "actionable certainties" (Wilson, p. 213). He points out that reports have a universal structure because they need to be intelligible to readers all over the world. We can extend this distinction to the narratives of the Philosophes and scholars as seen in memoires, articles and pamphlets on the one hand, and the empirically oriented reports as seen in the case of Madras inquiry. While the narrative form used detailed depictions to influence readers and constructed a concerned public, the report form sought to produce information that was readable from the centers of calculation, that

\footnotetext{
${ }^{21}$ Ashenden and Ashforth's conceptions of inquiry depart from Foucault's conception of inquiry articulated in the lecture "Truth and Judicial Forms." Where Foucault understands the inquiry as a method focusing on the past events, Ashenden and Ashforth show that this interest with the past has implications for the present in terms of reconstituting state authority. It has implications for the future as well, since these inquiries produce recommendations for future adoption.
} 
is, capital of the state. Such reports could also be compared and translated into statistical information for state action.

In the $20^{\text {th }}$ century, not only do we see the spread of this technique of government across the globe but its deployment in other political contexts, especially in inter-state relations. The early inquiry commissions embodied a new form of asserting of power, constituted new subjects and fields for regulation. In the international sphere, inquiry commissions and bodies with similar mandates fulfilled parallel functions on nationstates. The next section looks at the international sphere to survey the proliferation of inquiry at this level, while also looking at the disciplinary technique of examination and its utilization by international bodies such as the League of Nations, or the United Nations. The inquiry as a technique looking at past events and the examination as a technique focusing on "real-time" compliance with norms co-existed in the international sphere. This inquiry method of information production and its templates were carried into the $20^{\text {th }}$ century and adapted to conditions of international politics. The inquiry method was synthesized with the disciplinary examination technique and deployed in monitoring state behavior from distributed centers of calculation. It is to these developments that the chapter now turns to.

\subsection{Invention of International Supervision}

Human rights became an international issue after the end of the WW2. Yet, the top-down implementation of human rights has been a difficult problem. In order to ensure the implementation of human rights in the domestic affairs of the states, international authorities needed certain techniques of representation and intervention. These techniques were mostly invented or developed under the auspices of the League of Nations (LoN), 
which was one of the first instances of institutionalized international supervision of sovereign states. The techniques invented and developed by the LoN were later adopted by human rights agencies such as the UN Committee on Human Rights. In order to understand how human rights were carried to and deployed in international politics, we need to conceptualize the techniques of international supervision to which human rights were attached. This contributes to my genealogical reading of the work of human rights by emphasizing that anti-torture policies have a polyhedron character, that is to say they are constituted by multiple trajectories. The main point of this section is not that League of Nations developed methods to improve human rights or it developed techniques to combat torture and ill treatment in mandated territories. The point is that the techniques of international supervision made the internationalization of human rights thinkable and possible. International governance of human rights is often understood within the context of the rise of a global civil society or spread of humanitarian sentiment beyond national borders. This section seeks to locate it within the context of development of technologies of international government. As such, it differs from the account of Darius Rejali, who argues that global monitoring of torture "began with intrepid journalists, lawyers, and intellectuals, mainly from Europe and the US" (Rejali, 2007, p. 40). My point is not about contesting the historical claims of Rejali but rather emphasizing the history of techniques rather than individual acts of monitoring. I think that the development of the techniques of supervision is important because they shaped the work of human rights for decades to come and set the horizons of the human rights activists. It also underlines that not only techniques of torture, which Rejali diligently documents, but anti-torture strategies as well, have a history. 
Many items in today's human rights toolbox, such as human rights commissions, official communications, fact-finding and monitoring hail from the experience of the League of Nations and particularly its mandate system. Thus, the LoN and the mandate system deserve a closer look to understand the history of these techniques. This section will briefly look at how this system was understood in the diplomatic discourse and formed as a result of negotiations, to which problem it was addressed, and its constituent parts that formed the basis of later international governance of human rights.

The LoN was established following the First World War as a result of the negotiations at the Paris Peace Conference of 1919 as a major innovation in terms of international organization. Before the League, the relations between the Great Powers were either of military or diplomatic character ${ }^{22}$ (Archer, 2001, pp. 9-14). But LoN was the first international political organization with a permanent bureaucracy and thus spurred a shift from multilateral diplomacy to international administration with an institutional archive and presence. Like the League, the mandates system was a result of the WW1. The end of the war posed the question of the control of the territories of Germany and Ottoman Empire and of the populations living in this scattered geography. Various proposals were made to find a solution to this problem. Many Allies saw these territories as an opportunity to compensate their loss of men and a means to put their economy back on track after the destruction inflicted by the war. Thus their preferred solution was annexation, and many had entered into secret arrangements as to which power will take where (Macmillan, 2002). However, in his "fourteen points" speech

\footnotetext{
${ }^{22}$ Steps to form a permanent diplomatic machinery (as opposed to temporary envoys) were taken at the Vienna Congress of 1814-1815 and there were several public international unions such as the International Telegraphic Union established in 1868. But these were not international political organizations.
} 
made in the US Congress just before arrival in Paris, US President Wilson opposed any outright annexation of the territories and called for "impartial adjustment of colonial claims" and consideration of native interest along with the claims of the allied governments (Ryan, 2008, p. 495). Jan Smuts, one of the members of the British Empire delegation in the Paris Peace Conference of 1919, suggested that the new LoN take control of the European territories which were "incapable of, deficient in power of selfgovernment" (Smuts, 1918, p. 11). These "elements of European civilization" were not ready for independence and if left alone, this part of the world could end up in a destructive war or under Bolshevism. They should be nursed towards political independence by experienced nations "subject to the supervision and ultimate control" of the LoN (Smuts, p. 19). The negotiations led to the establishment of the Permanent Mandates Commission. These elements of nascent international administration would later inspire the architects of United Nations in devising ways to protect human rights internationally.

This system, which the contemporaries called "international supervision" (for instance see White, 1926), represented as much a transition to a new type of colonialism as the development of international regulation and monitoring. The intellectual basis of the mandate system was found in the liberal criticism of the so-called New Imperialism. A new generation of liberal lawyers, from mid $19^{\text {th }}$ century on, was advocating limits to the actions of sovereign states (Koskenniemi, 2002). For them, disregard of the limits to state action was wrong not only because it could encroach upon the rights of other states but also because it had negative impact on the sense of an international community with its own principles of co-existence and solidarity against aggression (Anghie, 2004, p. 
126). Liberal thinkers such as J. A. Hobson were critical of the scramble for territories and resources at the end of the $19^{\text {th }}$ century as it entailed barbarous practices and instituted a system of monopolized territories instead of free competition. Instead of extermination of the native populations, the liberals, in conjunction with Fabians and radicals, suggested the institution of an "educative trusteeship" over the "lower races" (Duffield, 2007, p. 21). This required the development of their capacities with the help of Western nations so that they can be self-reliant while preserving their natural community. This relationship of trusteeship between a Western nation and a native population, however, had to be monitored by other Western nations to ensure that it conformed to the principles of liberal paternalism. Before the "third world" came under scrutiny in the context of UN and similar organizations, the international administration sought to supervise the actions of "civilized nations" in the mandated territories under their control.

In the negotiations in Paris ${ }^{23}$ the proposals of Smuts were adopted with a twist: while European nations would become independent on the condition of unilateral minority rights obligations, the non-European territories would be controlled by mandatory powers under the supervision of the League. ${ }^{24}$ The system emerged, as the first director of the mandatory section of the League secretariat William E. Rappard put it, as "a kind of compromise between... advocates of annexation and... international

\footnotetext{
${ }^{23}$ Five treaties were produced in the negotiations. Treaty of Versailles was signed between the Allies and Germany on June 28, 1919 and Covenant of the League of Nations appended to it. The mandate system was laid down in the $22^{\text {nd }}$ and $23^{\text {rd }}$ Articles of the covenant.

${ }^{24}$ Mandatory powers would be given control of the territories that were categorized into three groups (A, B and C) "according to the stage of their development the geographical situation of the territory, its economic conditions, and other similar circumstances." Japan, Britain, New Zealand, Union of South Africa, Belgium, France and Australia received colonies in the form of mandated territories with the condition of international supervision.
} 
administration" (Wright, 1930/1968, p. 24). The oft-cited Article 22/1 of the League covenant read:

To those colonies and territories which as a consequence of the late war have ceased to be under the sovereignty of the States which formerly governed them and which are inhabited by peoples not yet able to stand by themselves under the strenuous conditions of the modern world, there should be applied the principle that the well-being and development of such peoples form a sacred trust of civilization and that securities for the performance of this trust should be embodied in this Covenant. (As cited in Wright, p. 591)

But how was this regime of control and supervision implemented? The success of the international supervision relied much on the techniques crystallized in the development of modern states. As James C. Scott (1998) argued, modern states sought to attain the objective of human welfare through what he called "high modernism." High modernist thinking entailed tasks such as increased production, technical progress, and a rational social order. To accomplish these tasks, high modernist political leaders and experts resort to techniques such as standardization (of language, weights and measures), planning, population registries, cadastral surveys, and large-scale designs of urban and rural areas. Briefly put, high modernism seeks to make the modern life amenable to government by making the terrain legible from above and afar (Scott, 1998, pp. 2-8).

To make the mandated and minority populations amenable to governance, architects of LoN developed tools that would help them see the developments from Geneva, and intervene in them. They relied on monitoring, verification and standard setting. Art. 22 of the Covenant required the mandatories (that is, those receiving a 
mandated territory) to submit an annual report concerning the territories under their control. This was one of the main instruments of monitoring the mandatory states by the "international community." These reports would be submitted to the Permanent Mandates Commission (PMC), also established in the same article. They would include information about aspects of the native life (health, justice, agriculture, trade, etc.) and would inform whether mandatory powers complied with standards such as "human and fair conditions of labor, just treatment," for which they were responsible. Every year, reports were examined by the mandates commission in the presence of a representative from the mandatory state, who were supposed to make clarifications and answer the questions of the commissioners.

Apart from the annual reports, another method for the "discovery of facts" was the petition. Peoples living in the mandated territories had the right to express their grievances through these letters. Petitions had to be submitted to the mandate authority rather than the PMC directly so that the mandatory could append its own observations about the matter. Petitions that were not sent through administrative machinery of the mandatory were rejected by the PMC. Moreover, PMC did not consider petitions that opposed the mandate itself (Wright, pp. 169-171). The flawed nature of this communication was recognized by the experts of international administration but still it constituted one of the sources of information for the PMC (White, 1926, p. 36). This instrument was later named as "communications" and included in the Optional Protocol to the International Covenant on Political and Civil Rights which was adopted by the UN General Assembly in $1966 .^{25}$

\footnotetext{
${ }^{25}$ See Article 1 (Office of the High Commissioner for Human Rights, 2007b).
} 
The annual reports and the petitions were not the only means to observe and intervene in the administration of mandated territories. PMC relied on an elaborate system of information gathering and verification. Apart from oral hearings of mandate representatives, PMC had reports of special commissions, and materials such as legal rules applied in the territories, summaries of debates concerning the mandates in national parliaments, newspaper articles, scholarly speeches and writings about mandates. Each mandated region had a file of its own, where information from different sources was compiled. This file system, reminiscent of files of inmates in "total institutions," made it possible for the PMC to track the development of the territories and supervise the Great Powers. In a regime of verification, PMC checked the data from the mandatory governments' annual reports against the data collected by the mandates section of the secretariat. This second source of information was compiled by the League secretariat. When there were grave differences in the way a mandate was depicted by a mandatory and the way it appeared in other sources, representatives of mandatory governments were invited to explain the discrepancies (League of Nations, 1935, pp. 111-112). It should be emphasized, however, that the members of the PMC saw supervision of the mandates as "joint endeavor" where they would exercise their authority "less as a judge from whom critical pronouncements are expected, than as collaborators" (as cited in Wright, 1930/1968, p. 196). This indicates that the LoN administrators did not seek to redesign international spaces in top-down manner. Their action was based on cooperation, dialogue and negotiation of the parties involved.

Evaluation and criticism of the mandatories required certain standards going beyond the vague formula of "well-being and development" of native peoples. The PMC 
could rely on provisions in the Covenant of the League concerning the prohibition of slavery, forced labor, military bases, etc. But in the face of lack of clear definition of standards and development, this body departed from "legalistic spirit" and formed its own dynamic standards by relying on the data from the reports and other sources (Anghie, 2004, p. 149-155). The PMC would give advisory opinion to the Council whether the mandatory powers lived up to their commitments. As Wright pointed out in 1930, PMC had to strike a balance between its double functions of supervision of and cooperation with the mandatory powers (Wright, 1930/1968, p. 196). Consequently, PMC's criticisms were of a limited nature. Still, they functioned as a mechanism of surveillance on the states and judged their conduct according to the norm of the welfare of the "native" populations and the good of international community. ${ }^{26}$

So what type of a power was at stake in the mandates system and what kind of an international sphere did the PMC envision and seek to put into practice? The mandates were being controlled on behalf of the League and the techniques outlined here established a relation of supervision between the PMC and the mandatories in the name of international, national and native interests (Wright, 1930/1968, p. 137). In a sense, the mandates commission represented a third party between the "native peoples" and the mandatory nations, embodying the will of the international community. From this perspective, this procedure was similar to the inquiry method of truth finding that we have seen in the previous section. The PMC inquired into the condition of the mandated

${ }^{26}$ There was considerable debate in the Council of the League as to the composition of the Commission. Proposals for a body comprising exclusively of non-mandatory powers and a suggestion to include a black member were rejected. In the end it was decided that PMC be composed of ten members with nonmandatory powers constituting the majority (White, 1926, p. 33). The members would not be appointed in a national capacity but on the basis of expert knowledge, that is to say experience in colonial administration (Wright, 1930, p. 140). One member would be female and there would be a representative from the International Labor Organization in addition to the ten commissioners. 
territories through the information that reached to it, and the oral hearing of the mandate representative made sure that it received the opinion of all interested sides. What the State represented in the commissions of inquiry (the neutral third party looking for the truth in the name of a greater good) was embodied by the mandates commission, which justified itself on the greater good of the international community. However, from another angle, the PMC also embodied disciplinary mechanisms. Given the syncretic functions of administration and cooperation, it is not possible to say that mandatory powers were in a hierarchical relation with the League. Still, the monitoring of the mandatory states at work in the territories, vigorous effort to verify their version of truth, setting of flexible standards, and continuous calls for compliance with them evinces a form of power akin to elements of discipline and surveillance as Foucault elucidates in Discipline and Punish (Foucault, 1979). Certainly, the PMC did not act like a prison authority. True, the ultimate punishment of the mandatory by giving the mandate to another country was a very distant possibility. Yet gaps between the practice and norms (standards) were incessantly monitored and reminded in the PMC. The procedures of this body functioned as an examination geared towards improving the behavior of the mandatory powers, that is to say, towards progress and potentialities. Whereas the inquiries mentioned in the previous section focused primarily on investigating past events, the examination as a method of power was geared towards progress of the observed object and its normalization (Foucault, 2000, pp. 1-89; Macmillan, 2009). Both the inquiry and the examination had normalizing effects but they achieved these through different means. While the inquiry as a form had a stake in representing the state in a 
ritual form, examination was less concerned to represent political authority but to monitor subjects.

The mandate system was simultaneously a system of international management of peoples. We can establish a similarity between the mandate system and the European state system coded in the 1648 Peace of Westphalia. Hindess (2008) argues that the European state system formed after Westphalia settlement was not limited to a partition of European continent between different states and a pledge for non-interference. It also constructed a system of conducting the state conduct, where the states were expected to act peacefully and develop themselves within reasonable limits without disnupting the balance of power. He pointed out that international liberalism propounded "supranational" (p. 269) government of peoples, by their own nation-states and encouraged peaceful relations between them. The mandate system, similarly, encouraged peaceful relations between states by managing the problem of territories without state through international supervision. Otherwise, the victors of the First World War could engage in yet another war of partition. The mandate system moreover, encouraged the management of what Duffield (2007, p. 9) has called "surplus" populations by mandatory states. Duffield argues that surplus population constitutes the main problematic of international development. It is a population that is not integrated into the capitalist economic system due to unemployment, lack of qualifications, or status. Colonial administration has come to understand native populations as such a surplus and opted to deal with this problem through the "educative" apparatus of mandate system rather than "extermination or eugenics" (Duffield, p. 10). Thus similar to the European state system, 
mandate system had implications for both the inter-state conduct and colonial administration.

In the introduction, I have pointed out that technologies (such as maps, charts, reports) not only make possible but also shape the activity of government. The way the reports of the mandates territories were prepared also shaped the work of supervision. The information gathered on the territories contributed to construction of the populations living in these geographies as "backward" peoples. Annual reports to the commission produced a certain way of seeing things and people in the territories, excluded certain "facts" and included others, cast the light on the events in a political way. These reports objectified mandate territories and populations as economic resources and biological entities by carrying information about the economic resources, health, mortality, hygiene, and labor to the LoN center in Geneva (Anghie, 2004). The mandatories were careful to measure the welfare of the populations and economic assets of the territory. In this way, the supervision of the mandates was guided towards the economic development and exploitation of the native populations. The sources of information and consequently the supervision excluded the political aspirations of the native populations by rendering this information irrelevant for the PMC and the LoN. The mandatories were careful to measure the welfare of the populations and economic assets of the territory. In a sense they were concerned about the "native interests" but they did not include any information about the desirability of mandate control in their reports (Rajagopal, 2003). After all, mandated territories were not ready to survive in the "strenuous conditions of the modern world." 
In terms of the techniques deployed, the PMC was the forerunner of the similar United Nations treaty bodies established in international treaties (Rajagopal, 2003, p. 67). For instance, like the annual reports from the mandatories, state parties to the Convention against Torture and Other Cruel, Inhuman or Degrading Treatment or Punishment of 1984 (UNCAT) had to submit a report to a body comprised of experts, explaining what they have done to keep up with their commitments under the convention. ${ }^{27}$ As Rajagopal (2003) points out, the structures of the League were reproduced in human rights regimes after 1945. Indeed, it was William E. Rappard (1946), the director of the Mandates section of the LoN, who suggested that the procedures and principles of the mandates section be reproduced in the United Nations system to protect human rights internationally. Thus, the techniques of visibility and management employed by the LoN for supervising the mandated territories migrated to the governance of human rights. The valuable "lessons" of the mandates section included the techniques such as monitoring, cooperative spirit of mandatory representatives and League administrators, and acceptance of petitions from "native" populations. Rappard also emphasized the appointment of monitors as independent experts. Being appointed by the Council of the LoN (similar to UN's Security Council) for an indefinite period, commissioners "were free to speak their minds" (Rappard, p. 122). This use of "independent experts" and petitions was later adopted by the United Nations Economic and Social Council in 1970. This was used in the "1503 Procedure" where communications from private individuals

\footnotetext{
${ }^{27}$ This was required in Article 19 of the UNCAT (Office of the High Commissioner for Human Rights,
} 2007a). 
regarding human rights abuses (petitions) can be sent to a group of appointed experts working in personal capacity (Normand \& Zaidi, 2008, p. 376). ${ }^{28}$

To sum it up, until now we have seen the development of disparate elements that formed the parts of international human rights practices in the $20^{\text {th }}$ century. The enlightenment period had kicked off the "moderation in punishment" (Foucault, 1979) and provided the justification for the abolition of corporal penalties and torture. Writings of the Philosophes would provide the language of opposition to injustices for the years to come. Its notion of torture, on the other hand, was supplanted by empirical knowledge of torture in the $19^{\text {th }}$ century. The methods of arriving at truth about torture came to be institutionalized in state practices in the same period. Moreover, these modes of finding truth, along with the procedure of examination, formed the basis of international supervision of states in the early $20^{\text {th }}$ century under the roof of League of Nations. In the coming pages, we will look at how these elements were brought together under the rubric of international human rights. Neither the inquiry and examination methods nor the international supervision were inherently related to the concept of human rights. This underwrites my claim that anti-policies of torture were not natural reactions to practices of torture but their organizational form was informed by international apparatuses of power such as the PMC. LoN way of supervision became one of the standards of human rights governance. Inquiry and examination developed as official apparatuses of knowledge became institutionalized. International supervision, moreover, was a series of techniques invented in the course of the problematization of surplus populations and stateless territories. Nevertheless, state procedures of knowledge (inquiry, examination)

\footnotetext{
${ }^{28}$ These petitions would then go to the Sub-Commission and the Commission on Human Rights. The latter body was replaced by the Human Rights Council in 2006 by a resolution of the UN General Assembly.
} 
and international techniques of state and population management will come together in the later years of the $20^{\text {th }}$ century to form the toolbox of international human rights practices. The chapter now looks at this episode.

\subsection{Strategies of Human Rights Protection in $20^{\text {th }}$ Century}

Dissemination of human rights as a precept in the government of peoples was a circuitous rather than a straightforward process. The predominant conception of human rights (as rights of man) until the $20^{\text {th }}$ century was that they were principles that were relevant only for the members of a national community, and a bulwark against the tyranny of aristocratic power overthrown by revolutions. The declarations of rights of man following the American and French Revolutions are paradigmatic examples of this outlook (Pagden, 2003). Outside the nation-state, the language of rights came up in international politics as rights of the state enunciated in cases of inter-state disputes over commercial transactions or frontiers and could be enforced by negotiation, arbitration and sometimes armed attacks. This conception of rights existed within the context of an international law that underwrote a sovereign mentality and concerned mainly with treaties between states, acquisition of territory and laws of war (Koskenniemi, 2002). It was possible to talk about the rights of the individual to the extent that he was an extension of the state in his role as a diplomat, a merchant or similar functionary. ${ }^{29}$

Thus, rights in international politics were an issue strictly between states. After the WW1, this bilateral framework was succeeded by an international framework for the

\footnotetext{
${ }^{29}$ An important exception to this notion of right as capitulation/exception to other states was the status of the religious minorities. These religious groups could take advantage of powerful states that professed to be the protector of a certain minority in cases of extreme injustices, such as massacres. This role of protector, such as practiced by France and Russia, was deployed mainly as an excuse to carve up territory from the Ottoman Empire.
} 
protection of rights through international law and institutions. However, this first happened through the notion of minority rights, and a general conception of human rights emerged only slowly, after the failure of this notion. The minority rights articulated the rights of man and international sphere (Mazower, 2004). At the Paris Peace Conference in 1919, President Wilson proposed an article to be included in the Covenant of the League that would guarantee the right to religious freedom and non-discrimination. The proposal aimed at safeguarding the post-WW1 order in Eastern Europe and the Middle East, which was the geography of disintegration, rebellion and explosive nationalism. The new states in this crossroads had considerable amount of discontented minorities under their control, and problems between the minority and the "host" state could easily destabilize the new order in the region, or the Allied powers thought. Later in the negotiations, this clause of generalized religious freedom was withdrawn and replaced with minority clauses that banned discrimination based on race, religion and language and gave the minorities the right to education in mother tongue and a share in public funds (Lauren, 2003). Newly independent or defeated states had to include these clauses in their treaties of peace with the Allies or they had to deposit a binding declaration for minority protection with the LoN, which would guarantee the rights. Either way these clauses would become constitutional rules above the national laws of these countries. In this case, the political logic of League protection was more about preserving the postWW1 order in Eastern Europe by preventing outbreaks of armed conflicts due to minority problems than extending geopolitical influence with reference to coreligiosity. ${ }^{30}$ The regime aimed "not so much minority protection as border protection"

\footnotetext{
${ }^{30}$ A case may be made for Middle East that minority protection there aimed not to stabilize but open up
} 
(Jones, 1994, p. 88). That is to say, the concern for minority rights stemmed from a concern to preserve the borders that had been agreed on after the end of the war.

As can be seen from this brief account, the emergence of the notion of minority rights in international politics was bound up with geopolitical considerations of the Great Powers of the time. Geopolitics, when understood as "geographical assumptions, designations, and understandings that enter into the making of world politics" (Agnew, 1998, p. 3), contributes to the claim of this study regarding the historical specificity of human rights activity. The geopolitical imagination in the interwar period was preoccupied with the viability of the states on the European continent and the prevention of a new war. The conception of the Eastern European countries as a problematical geography and minority problem as a threat to the boundaries of the post-WW1 political order informed the notion of minority rights. In this way, minority rights became not only an obligation of Western civilization but also a geopolitical necessity. The minority rights appeared to be not only a "local" issue between the state and the minority population but also a problem of world politics. This impingement of geopolitics on the discourse and practice of rights was not peculiar to the interwar era. As it will be apparent in the coming pages, human rights activity and anti-torture policies in particular were often informed by geopolitical considerations. As geopolitical imaginations shifted, human rights challenges were understood in novel ways.

The new minority protection regime formed a routinized system that tried to secure rights of minorities through legal safeguards and LoN supervision of states of concern. League procedure broadly relied on a right of petition by minority groups. 
Complaints that were found credible would be investigated by an ad-hoc Minority

Committee with a view to reach a settlement. Otherwise, the complaint would be handled by the League Council or Permanent Court of International Justice (Lauren, 2003, p. 116). As such the petition mechanism constituted the LoN as a neutral third party. Based on the international legislation, the minority right to petition was reminiscent of the social contract between the citizens and the state. In return for rights, justice and order, minorities would accept their subordinate position in the nation-states. When the "host states" did not conform to agreed principles of minority protection, individuals were entitled to appeal to a higher authority that represented the supreme ratio of the modern civilization. In this way it underlined the idea of international community which would assume increased significance as a justification for human rights after the WW2.

The instrument of petition carried forward and re-invented many similar practices found in early modern states in the $17^{\text {th }}$ century. ${ }^{31}$ It presupposed political subjects who were disgruntled but still appealed to the higher values of the social contract. It also presumed publics that chose to act rationally through the medium of written word rather than resorting to violent methods of expression. Therefore, the technology of petition also constituted minority citizens as international legal personalities. However, this regime failed to fulfill its functions. The western states did not want to weaken newly independent states by keeping the minority protection issues on the international agenda and thus calling into question their authority. The minorities, moreover, gradually became

\footnotetext{
${ }^{31}$ The institution of petition can be observed in $17^{\text {th }}$ century in both England and American colonies. In England, petition was used by citizens to find solutions to their grievances with the government but mass petitioning was also used for political pressure (Leys, 1955). In colonial America, petitions were also used by citizens for private disputes. Governments saw the mechanism of petition as a source of information and an opportunity to expand their authority (Higginson, 1986).
} 
discontented with Geneva bureaucracy that did not produce tangible results (Mazower, 2004). Moreover, despite formal declarations and treaty commitments, Eastern European states were resistant to intervention from the League due to feelings of injustice: While both Western and Eastern European states had sizable minorities (e.g. Alsace was returned to France), it was only the Eastern Europeans who were subjected to minority clauses in return for recognition. This was protested in the LoN platform and Poland unsuccessfully tried to introduce a resolution that extended minority protection to all members of the League. In this context, the Assembly of the LoN adopted a resolution in 1922 that expressed "the hope" that states not legally bound with the minority clauses also treat their minorities with a "high standard of justice and toleration." The nascent international organizations like International Diplomatic Academy, International Law Institute and International Federation of the Rights of Man, on the other hand, did not find proposals to generalize minority protection useful. Rather than a generalization of minority protection, they advocated the acceptance of a bill of rights of man as a guide for relations between the individual and state. Taking the American and French declarations as models, in the 1920s these organizations adopted several resolutions that contained a catalogue of rights that applied internationally.

The framework of minority rights failed in the 1920s, but it was not immediately supplanted by the framework of human rights. Human rights language was adopted by dominant powers only after the Second World War started (Burgers, 1992, p. 452-454; Lauren, 2003, p. 106-109). In this war, British and American efforts were defined in terms of a struggle of "democratic and peace loving peoples" against aggressive dictatorships. In this struggle, human rights and freedoms were evoked especially to 
overcome an isolationist and pacifist American public. Beyond this instrumentalization of human rights, the US executive also saw human rights as a safeguard against future aggressions. Wilsonian concern for minority problems was replaced with a concern for domestic political situation. The thinking was that outbreak of war in Europe and Far East was very much due to the economic deprivation and persecution. States that pursued repressive policies inside were likely to use aggression in international affairs. Thus even before the US entered the war, President Roosevelt had declared that "we look forward to a world founded upon four essential human freedoms... freedom of speech and expression, freedom of worship, freedom from want and freedom from fear. Freedom means supremacy of human rights everywhere" (Roosevelt as cited in Ishay, 2007, p. 481). The Atlantic Charter declaration signed by Britain and US in 1941 reformulated this as "all the men in all lands may live out their lives in freedom from fear and want." The shift from minority rights to human rights in official attitude was also a response to the criticisms of inequality from non-Western leaders. Unlike "minority rights," human rights were acceptable because they problematized state authority not on the basis of specific ethnic populations and new statehood but on the basis of inherent rights potentially expandable to all states in the international sphere (Best, Hanhimaki, Maiolo, \& Schulze, 2004; Forsythe, 2006; Mazower, 2004, p. 383-389).

As argued in the introduction, the course of human rights practices after the WW2 can be fruitfully analyzed in terms of several strategies (see Table 2.1). The notion of strategies allows us to view human rights practices in terms of different logics and knowledges and explore identities they presume. Additionally, the notion of strategy brings in the aspect of unpredictability and complexity of human rights practices. In this 
way, my dissertation seeks to avoid a teleological account of anti-torture efforts, the endpoint of which is already known. Rather than seeing these struggles and policies as a continuous process, as different expressions of the same kernel, and the growth of the seed that the Philosophes have planted, we shall analyze them in terms of the strategies adopted by different actors at different times, towards different subjects and with different logics. This would give us a better analytical purchase on the spectrum of human rights practices. Below I engage in this analysis by identifying three different strategies. The first strategy emphasizes legal expertise and legal profession over other actors in the global society. My findings regarding this strategy is in some ways similar to that of Dezalay and Garth (2006) who prefer the term "elitist moralism." The second strategy carries some traces from the Enlightenment but is in a more antagonistic relationship with the offending states. The third strategy develops a new perspective on torture, by reducing certain instances of this problem to bureaucratic failure. In analyzing these strategies, I chose to focus more on their modes of working, the objects and subjects they privilege, rather than the "norm entrepreneurs" that contributed to their design and implementation. In this way, I emphasized their collective and mobile nature. Now let us examine these strategies in detail. 
Table 2.1

Anti-Torture Strategies

\begin{tabular}{|c|c|c|c|}
\hline & Nature of Torture & Tasks & Actors \\
\hline Constitutional & Cruelty, Nazism & $\begin{array}{l}\text { Build Political } \\
\text { and Moral } \\
\text { Consensus }\end{array}$ & $\begin{array}{l}\text { Political Leadership, } \\
\text { Jurists, Publics }\end{array}$ \\
\hline Accusatory & $\begin{array}{l}\text { Cruelty, } \\
\text { Systematicity, } \\
\text { Political }\end{array}$ & $\begin{array}{l}\text { Monitor, } \\
\text { Shame \& } \\
\text { Criminalize }\end{array}$ & $\begin{array}{l}\text { Statespersons, Activists, } \\
\text { Publics }\end{array}$ \\
\hline Preventive & $\begin{array}{l}\text { Incapacity, } \\
\text { Haphazard }\end{array}$ & $\begin{array}{l}\text { Monitor, } \\
\text { Cooperate \& } \\
\text { Train }\end{array}$ & $\begin{array}{l}\text { Statespersons, Experts, } \\
\text { Technology }\end{array}$ \\
\hline
\end{tabular}

\subsubsection{The Constitutional Strategy}

The introduction of the vocabulary of rights to international politics, the emphasis put on human rights as an overarching value for the peoples of the world and the nascent tools (petitioning, monitoring and inquiry mechanism) set the climate for the subsequent human rights practices. After the WW2, there was a growing political consensus on the "respect for and the observance of" human rights around the world expressed in the Universal Declaration of Human Rights. In this context, we can see the emergence of a strategy; series of proposals, tactics and understandings to improve and entrench human rights. This first strategy is what I call the "constitutional strategy" developed mostly by diplomats, lawyers and scholars. The reason I named this strategy such is this: In 
domestic settings, constitutions act as guarantees of rule of law and provide a framework which is supposed to express a political consensus and under which other legislation and political practices become possible. After WW2, human rights attained such a level of acceptance. International human rights law was seen as the guarantee and usually the final resort to deal with violations of human rights. Here my reading of international law and legal expertise goes beyond the conception of international law as an expression of sovereign power. Besides the actions of nation-states, my focus foregrounds the practice of international law as an "exercise of power" (Orford, 2003, p. 77). As Orford argues, international lawyers are not "neutral" and "apolitical" actors carrying on a solely technical function. Their writings help constitute certain subjects and domains, make them intelligible through the production of knowledge.

This subsidiary strategy preferred an action model where violations should first be dealt at the local and national levels, just like in a legal system where cases go first to the courts of first instance before going to higher courts. An international intervention should be considered only after the exhaustion of local remedies or flagrant violations. Proponents of this strategy express an unflinching confidence in the capacity of law, especially international law and legal experts, not only to bring about peace and order but also to solve the problems of humanity by uniting them in world community. Beyond a constitutional framework, law provided the automatic mechanism that would render political interventions unnecessary. This strategy deploys tactics of persuasion, moral pressure on governments or mediation and conciliation between complainants and governments. Constitutional strategy utilizes law to establish the necessary institutional environment and legal authority to engage in these acts. 
This strategy is characterized by the problematic of enforcement, which is entangled with questions of information/supervision and nationalism. In the 1940s when this strategy was formed and put to work, human rights had more or less attained general acceptance and legitimacy. At the San Francisco Conference which established the United Nations, there was overwhelming support for an order based on human rights despite the diversity of views as to how this would be accomplished. The disagreement concerned the authority that would enforce it (state vs. international) and which rights (political vs. economic and social) should be accepted. The fact that there were no votes against the Universal Declaration of Human Rights at the UN except eight abstentions attests to this general acceptance of the language of human rights. However, despite this consensus, enforcement of international rights was fraught with difficulties. Besides the obstacle of sovereignty, the constitutional strategy had to take into consideration the national sentiment and the public opinion. As will be seen below, strategy provided for tools that respected and managed these factors while pursuing the concern for international rights. Another issue was surveillance of situations in the world where rights were violated. Effective monitoring and intervention in human rights crises would not be possible if there was not steady flow of information from states. One British delegate stressed the impracticality of international enforcement as it required "an international detective service" (as cited in Lauren, 2003, p. 169). Solution of this issue incorporated the LoN formula of self-surveillance through country reports but also relied on the vigilance of legal professionals, non-governmental organizations and individual petitioners. 
Hersch Lauterpacht (1897-1960), an émigré international lawyer, has been immensely influential in the formation of this strategy. He studied international law in Vienna and London and later became a member of the British prosecution team at the Nuremberg trials. A judge of the International Court of Justice in 1954, his proposals have influenced the writing of the UN Charter and later covenants on human rights (Koskenniemi, 2002; Lauterpacht Centre for International Law, 2009). Like many scholars of his generation he had an international focus, problematizing "the sovereign State" and nationalism as obstacles to the development of a rational world order. The State's purpose was itself and this circular logic was complemented by self-judgment, the absolute authority to interpret international law according to self-interests and understanding. So long as the State remained the supreme authority in the world, sovereignty would preclude a universal vision of cosmopolitan interests necessary for the realization of human rights. His writings also aimed to form a tradition of international law "for promoting and protecting... the interests and the welfare of the individual" by constructing a genealogy of natural law that linked the Stoic philosophers of ancient Greece to contemporary international protection of human rights through Grotius and Victoria (Lauterpacht, 1943, p. 27).

Lauterpacht's support for supreme international law did not mean that he saw international legal mechanisms as the immediate solution. The constitutional strategy allowed for managing and negotiating problems and a degree of flexibility within the context of law as long as political objectivity and disinterestedness were preserved. Thus, he expressed dissatisfaction with efforts to bring human rights violations directly in front of an international court in countries where domestic "courts have been faithful trustees 
of the rights of man." In these states, international courts should have a secondary character and complaints should first go through a "procedure of investigation, persuasion and conciliation." Public opinion was also a significant force that should be taken into consideration by international procedures to protect human rights. International courts should make sure that their decisions are acceptable to the public sentiment by including high judges from the country under question into the court decision making process on a case by case basis (Lauterpacht, 1950, p. 286-292). This approach to the problems of enforcing international human rights is a legacy of the cooperative ethos of the League's mandates commission. It will be remembered that PMC avoided top-down style of governance but encouraged a "conference with interested parties" (White as cited in Wright, 1930/1968, p. 195). A similar propensity to negotiation is also evident in the writings of Moses Moskowitz who for many years represented a council of Jewish organizations at the United Nations (Moskowitz, 1958, p. ix). He argued that allegations of human rights violations could ultimately be solved by supranational bodies composed of independent legal experts. The latter, despite conforming to highest judicial standards, would not decide on issues "in the manner of a judge in a lawsuit... but settle questions in the manner of a friendly mediator" (Moskowitz, p. 153). For this reason, international expert bodies would better be organized regionally to be close to the problems and have sufficient political and psychological relationship with the governments to exert powers of persuasion and moral pressure.

Proponents of this strategy of human rights can also be surveyed through their ontology of world order. Without denying the permanence of nation-states, they identified the individual ("the Man") as the entity which international law aimed to serve. 
Individual does not yet have a fully developed agency in world order due to the sovereign suppression of his existence. Yet, the "Man must become the measure of all international endeavor" (Moskowitz, 1958, p. 20). The Man was the telos of international law which would emancipate him by making him "an object and subject of international concern" (Moskowitz, 1968, p. 163). Until then, individual agency seemed to be limited to the expression of public opinion preferably in favor of law of nations and to initiatives and complaints $^{32}$ to international bodies composed for the protection of rights.

I have argued in the introduction that human rights practices should also be analyzed in terms of the subjects that they prioritize. In this respect, the constitutional strategy accords greater agency to jurists and similar experts operating in both national and international contexts. This aspect of the strategy can be clearly detected in the reports by the "Commission to Study the Organization of Peace" (CSOP). This body was formed in United States by experts on international affairs after the outbreak of WW2 to intervene in the postwar planning of the international order. Some members of CSOP were later involved in the San Francisco conference in various capacities and in the words of US Secretary of State Dulles, "made an indispensible contribution to the creation of United Nations" (CSOP, 1973, p. xii). In their Preliminary Report prepared in 1940, CSOP identified "law of nations" as the only way to stop the advance of modern scientific warfare (p. 3). CSOP later proposed an incremental approach to safeguard human rights by first studying different national human rights practices and identifying common denominators in an international conference. This would bring about the common denominator, the constitution of world order. In a move reminiscent of PMC

\footnotetext{
${ }^{32}$ The use of complaint mechanisms and petitions is another legacy of the mandates system's toolbox for defending rights.
} 
commissioner William E. Rappard's call for deployment of international expert bodies in human rights questions, the commission called for a UN Commission on Human Rights composed of jurists, other experts with "powers of investigation and advice," and argued that an international bill of rights in general terms should be gradually expanded to adopt higher standards. Attempting to impose uniformity on different national practices was neither desirable nor feasible (pp. 169-171). Human rights should be safeguarded "with due regard for, and utilization of, the legal system and habits of each country" and national legal institutions should become the instruments to protect rights of individuals that are outlined in international law. CSOP did not propose to marginalize Court of International Justice but saw it as a last resort and believed that post-war era will be a time of new constitution writing and thus present an opportunity for the US to shape foreign national legal systems for human rights protection (pp. 175-177).

The emphasis on legal experts was not limited to CSOP. The International Commission of Jurists (ICJ), one of the early human rights organizations founded in 1952, brought together the elite of the legal profession in Geneva to oppose abuses in the communist countries (Tolley, 1994). Similar to the CSOP, the ICJ had links to the American establishment through the Council on Foreign Relations. Moreover, it was supported and funded by the Central Intelligence Agency. Tolley argued that its objective was to "mobilize... in particular the juridical forces" (p. 34) to improve human rights in the world, but especially in those countries under the Soviet influence. This would be carried out through several means. In its 1955 Athens Congress, the ICJ adopted the "Act of Athens." This declaration privileged legal experts as prominent actors in the struggle for the establishment of rule of law as a safeguard of universal human rights. Judges were 
called upon to "be guided by Rule of Law, protect and enforce it without fear or favor and resist any encroachments... on their independence," while lawyers should "preserve the independence of their profession" (Tolley, p. 41). Jurists would also carry out quasijudicial hearings about human rights abuses, the conclusions of which were distributed throughout the world via media and ICJ's network of national sections (Dezalay \& Garth, 2006).

For CSOP, international protection should be advanced without disturbing the national sentiment of the peoples. Commissions on Human Rights should infuse the public opinion in regards to the importance of human rights and link with local committee of human rights that would present the "international viewpoint" before national tribunals (CSOP, 1973, p. 182). In times of flagrant and persistent human rights abuses that risk international peace, an exceptional mechanism would be instituted where the Commission could be empowered by Great Powers to establish "branch offices in trouble zones for the purpose of providing legal aid... to persons before national tribunals" and follow the situation on the ground (p. 183).

The opportunity to shape national legal systems that CSOP mentioned came after the war and United States was able to "guide" the process of constitution making towards including human rights provisions in the texts. Japanese constitution and German "Basic Law" provide practical instances of the constitutional strategy to steer human rights practices towards a legal sphere. Peace treaties with Axis powers also included clauses to safeguard rights. For instance, Italian treaty contained commitments to protect freedom of expression, opinion, religion and press as well as prohibition of fascist organizations (Holcombe, 1948, p. 100-105). In this strategy, national legal systems were given the role 
of conveyors of universality to the national sphere. National judiciaries should be first aids to protect rights and freedoms since judges had a better knowledge of acceptable local practices and would preclude the perception of foreign imposition. The "national sentiment" was thus one of the questions confronted. On the one hand there was the threat of public opinion reacting to international human rights concerns if they were imposed directly and in an unmediated fashion. On the other hand, public opinion could bring pressure upon the governments to respect human rights if they were sufficiently informed. Moskowitz called this the "enlightened interest of nations" (Moskowitz, 1968, p. 74). Judges were imagined as decisive allies in this strategy. They were the ones who could instill universalism in the national sentiment since they were both engaged with international human rights and yet sufficiently nationally rooted to nullify accusations of foreign imposition.

The constitutional strategy did not offer elaborate analytical studies on the causes of human rights violations. Influenced by the Nazi example, it broadly conceived these acts as logical consequences of sovereign statehood which did not recognize limits on its power (Lauterpacht, 1950). The existence of a natural right tradition in the country, a bill of rights as found in UK or USA was helpful but this did not annul the self-serving sovereign logic. It was also recognized that human rights principles were not always very popular with populations, especially if they were not well informed and were under the influence of extreme nationalist fervor. The implication was that states were violating rights willingly and not due to a failure. Only in the late 1960s, it is possible to detect a more analytical approach to human rights violations and their causes. For instance, Sean MacBride, the secretary-general of International Commission of Jurists, provides not only 
a classification of violations according to their context (international armed conflicts or internal conflict) and magnitude but also posits that there might be marginal and individual cases in countries with a rule of law "at a time of political stress or... due to bureaucratic inaptitude" (MacBride, 1968, p. 152). With the notion of bureaucratic inaptitude, MacBride brings up the significance of capacity to uphold civil and political rights. In the human rights discourse of the time this notion of capacity was usually evoked in the context of social and economic rights, which requires state's positive action rather than in the context of civil and political rights. Conventionally, it has been recognized that capacity to collect taxes and produce social policies was a prerequisite to provide welfare for the persons living in a certain nation-state. MacBride's points differed from this conventional understanding by stressing the necessity of bureaucratic capacity for ensuring civil rights. However, under the constitutional strategy, the issue of capacity was not explored thoroughly. This issue of capacity would later become a significant domain of intervention by international actors to develop human rights within the framework of preventive strategy.

Adherents of the constitutional strategy included not only scholars and NGOs, but diplomats as well. Shortly after the Second World War started, American diplomats began to ponder ways of organizing the post-war global politics in line with the "national interest." In this effort, Sumner Welles, who enjoyed cordial relations with President Roosevelt, emerged as a prominent figure influenced by the liberal views of President Wilson (O'Sullivan, 2008). Welles took part in the drafting of the Atlantic Charter and he privately and publicly advocated free trade, "natural rights of all peoples to equal economic enjoyment" and the limitation of armaments (Welles cited in Normand \& 
Zaidi, 2008, p. 85). According to O'Sullivan, Welles convinced the American leadership to establish an "Advisory Committee on Problems of Foreign Relations" under the State Department so that Washington could avoid the postwar political "chaos" that characterized the Paris Peace Conference of 1919 (O'Sullivan, Chap. 3). This committee would determine the policies to be pursued for post-war peace settlement and economic recovery.

This American postwar planning process that Welles emphasized saw different proposals for the international protection of human rights. One of these proposals was formulated by the Special Subcommittee on Legal Problems that formed part of the American postwar planning bureaucracy. Lauren points out that this Subcommittee was the first official body to study extensively (and secretly) the problem of international human rights and their implementation. According to Lauren, the body was influenced by the diplomat Sumner Welles, who was a firm believer in human rights. Moreover, CSOP and the American Law Institute ${ }^{33}$ participated in the meetings of the Subcommittee (Normand \& Zaidi, 2008, p. 96). Several draft declarations of human rights and eventually a draft international bill of rights was finalized in December 1943 by this subcommittee. It was proposed that:

Human rights, shall be guaranteed and constitute a part of the supreme law of each state and shall be observed and enforced by its administrative and judicial authorities... any law or constitutional provision to the contrary notwithstanding. (As cited in Lauren, 2003, p. 163)

\footnotetext{
${ }^{33}$ American Law Institute was established in 1923 to improve the administration of justice in the Unites States. It was engaged in work to prepare an International Bill of Rights (Normand \& Zaidi, 2008).
} 
Thus, the subcommittee had adopted again a constitutional strategy for international protection that emphasized international legal instruments. However, this draft was defeated due to considerations of sovereignty. Human rights language was useful for the Allied leaders but it also led to an anxiety that these commitments could jeopardize domestic political situation and limit their actions. The US executive was concerned that a human rights protection system based on enforceable international law would overturn racial segregation inside the country and thus create a backlash especially from the southern states. Britain, on the other hand, was concerned about ramifications of a binding treaty for its colonial possessions. ${ }^{34}$ The Soviet Union, too, had problems with such a treaty as it was pursuing repressive policies domestically. These considerations led to downgraded human rights proposals at Dumbarton Oaks and San Francisco conferences convened to negotiate the formation of United Nations and postwar order. The ensuing UN Charter became the first international treaty that enshrined human rights language. As its architects also conceded, this regime was very much designed not to be enforceable (Morsink, 1999, pp. 21-23; Normand \& Zaidi, 2008). However, the UN Charter was not the final point in search for international protection through a constitutional strategy. In the second session of UN Commission on Human Rights in 1947 it was decided that an international bill of rights would be composed of a declaration of rights, a binding covenant and specific measures for implementation prepared (Lauren, 2003, p. 232).

\footnotetext{
${ }^{34}$ These tensions would surface in the negotiations running up to the Universal Declaration of Human Rights. When the right to change religion was suggested, the representative of Saudi Arabia asked Western delegates whether they had consulted with the Muslim populations under their control (Morsink, 1999).
} 
The influences of a constitutional strategy for protection of human rights can also be seen in the Council of Europe's European Convention on Human Rights which was adopted in 1950 and became operational three years later. The European elite's belief in the need to entrench liberal political systems against a possible resurgence of totalitarianism and fascism; and secure parliamentary democracy while rebuilding the continent formed the main segments of the consensus underpinning Council of Europe (Moravcsik, 1995). The Convention went much further than the existing systems of protection by constituting a Commission with powers of investigation and a Court that would decide whether there has been a violation of the Convention. Similar to the CSOP idea of common denominators, it initially aimed to protect rights and freedoms that were already in practice in Western Europe (Madsen, 2007). Moreover, it adopted a conciliatory and cooperating attitude towards states that have been accused of violating the convention. The Commission's function was defined as "to secure a friendly settlement of the matter on the basis of respect for human rights" (Robertson, 1960). Moreover, with a constitutional spirit, the Court required the exhaustion of domestic remedies before acting on a complaint. The legacy of the inquiry method is evident in the construction of this institution in that the authority to speak truth was granted to a body of experts.

The constitutional strategy was in many ways limited to the world of international legal experts. It operated at a time when this elite group was committed to the struggle of human rights through the operation of mostly legal methods. As human rights increasingly became a "grass roots" cause and as activists problematized abuses in 
different ways, this strategy came to be supplanted with new problematics and tactics. The next section explicates this transformation in human rights practices.

\subsubsection{The Accusatory Strategy}

In the discourse of the constitutional strategy of human rights, the latter were often seen as an associated bundle and specific rights (such as freedom from torture) were not emphasized at the expense of others. This reflected a conception of rights as an allencompassing civilizational principle, a forward point in the unfolding of human history. Human rights violations were conceived as civilizational and philosophical problems rather than specific and contextualized issues. This sustained an affinity between the immediate post-WW2 human rights discourse and the Enlightenment discourse of natural rights. Moreover in both the Enlightenment and the post-WW2 human rights politics, the agents of human rights were prominent intellectuals. The struggles of ordinary persons were not ignored but the action of elite figures such as American First Lady Eleanor Roosevelt, the French jurist René Cassin or the Lebanese philosopher and diplomat Charles Malik were emphasized. ${ }^{35}$ Human rights were often the endeavor of the wise and the sage. At the same time, this strategy relied on a binary structure of West vs. East, which embodied opposite poles in terms of the proximity to the human rights ideal. As Dezalay and Garth explain, human rights practices in the 1950s were "a counteroffensive on the terrain of the great legal principles" (Dezalay \& Garth, 2006, p. 233), that is, in some ways a reaction to the Soviet capture of these principles. Thus, there was little

\footnotetext{
${ }^{35}$ Roosevelt, Cassin and Malik were members of the Commission on Human Rights composed of eighteen government representatives that drafted the Universal Declaration of Human Rights. They represented U.S., France and Lebanon respectively. For a history of the drafting of Universal Declaration see Morsink (1999).
} 
space in this strategy to think about particular rights or the culpable links between the Western world and the rights abuses elsewhere. In the 1960s, we witness the ascent of a new sort of human rights strategy, what I call the accusatory strategy. This strategy is named as such due to its adoption of "mobilization of shame" (Joyce, 1978, p. 75) against governments by gathering information about their abuses, publicizing these actions and accusing them of willful violation or tolerance of abuses. Perhaps one of the most powerful articulations of this strategy is found in the words of Martin Ennals, the Secretary General of Amnesty International (AI). ${ }^{36}$ In his essay on the 1973 Conference for the Abolition of Torture organized by AI, he sent a stern warning to the states:

Now pressure on offending governments will be increased, exposure of torture practices stepped up.... A central bank of information about torture and all its ramifications will soon be established, collecting data from all over the world. Proven instances of torture will receive instant, global publicity. (Ennals, 1973, p. 14)

As seen from this quotation, the accusatory strategy did not share the sensitivity of the constitutional strategy, inherited from the LoN, towards the "national sentiment." The distinguishing features of this strategy were not limited to shaming, though. Wider deployment of inquiry and examination techniques of speaking truth, efforts to rally actors around a unitary definition of torture, criminalization of torture internationally, resort to the legal instruments to aggravate the effect of shaming were interconnected tools in this strategy. Shaming required the collection of reliable information through observation; stable definitions of torture were necessary for establishing an aura of

${ }^{36}$ Ennals was a British human rights advocate who served as the Secretary-General of the AI between 1968 and 1980 (Martin Ennals Award Website, n. d.). 
objectivity and criminalization and the seal of approval by the courts contributed to a greater authority for the human rights activists. It is also notable that AI members adopted procedures such as monitoring and collection of information ("central bank of information") which were used by the LoN to supervise mandated territories. This central depositories of information functioned as what Bruno Latour calls "centers of calculation" (Latour, 1987, p. 223), places and institutions where local acts of state violence etc. are turned into "violations of human rights" and then disseminated in human rights reports. The "power" of human rights advocates relied on such socio-technical procedures first used at the international sphere within the context of LoN. Without these inscriptions, without carrying the distant violations into the AI headquarters in London, they could not act upon the actions of states. But before going into the detail of these points, let us look at the broader historical conditions of this strategy.

The 1960s saw the emergence of a more active and vigilant human rights advocacy. Amnesty International, for instance, was established in 1961 as a new way of responding to what was perceived as the increasing human rights violations and recourse to political imprisonment in Europe (Buchanan, 2002, p. 581). Amnesty International amended its mandate in 1971 to include struggle against torture (Clark, 2001). This organization pioneered the grassroots intervention in human rights violations with the letter and "adoption" methods. This shift to "mass movements" was in some ways a response to the elitism of the earlier human rights organizations such as ICJ. Amnesty branded itself as an "international movement" (Buchanan, 2002, p. 591) that would mobilize publics and pressure on governments. Besides seeking to be influential through well-connected individuals, intellectuals and governments, it was believed that human 
rights movement should rely on common people and media coverage as well (Dezalay \& Garth, 2006). Local Amnesty groups were instituted in Western countries to adopt three prisoners who were being tortured or arbitrarily detained (Power, 1981). These groups were asked to write letters to the governments suspected of torturing or otherwise ill treating detainees. The mechanism of petitioning was used in other ways as well. For instance, AI had collected one million signatures for its petition calling for a UN declaration on torture (Amnesty International, 1984).

As the post-WW2 optimism for the development of democracy was replaced with pessimism, the nascent human rights community embraced a language of emergency and instant interference made possible by the surveillance mechanisms. Monitoring abuses and active intervention in situations became more prevalent as international organs and organizations with human rights mandates were established. The campaigns of Amnesty International provide ample examples of this sort of action. The newspaper editorial that launched the AI is infused with such an understanding. "The important thing," Peter Benenson, the founder of the AI wrote, "is to mobilize public opinion quickly, and widely..." (Benenson, 1961). Benenson wrote that rapid action was necessary because early intervention could prevent further crackdown and a drift towards "civil war" which would complicate and prevent the release of prisoner of conscience. Especially after Amnesty focused its work on torture and ill treatment, this emphasis on urgency became more pronounced. Working to prevent torture in Brazil following the coup in 1972, Amnesty activists devised the "urgent action network." The network was designed to work "much like an emergency staff in a hospital" (Amnesty International USA, 2011b) where news of emergency situations (i.e. a threat to an individual) would trigger instant 
pressure on the government involved via letters and other means of communication. The urgent action network was first used in 1973, when a Brazilian professor of economics at the University of Sao Paulo, Loiz Rossi, was detained. When the news of his arrest reached London headquarters, Amnesty issued its first Urgent Action leading to a flood of letters to the prison authorities in Brazil (Amnesty International USA, 2011a). ${ }^{37}$ Besides urgency, the accusatory strategy differed from the constitutional strategy in its disregard to the "national sentiment." Many supporters of Amnesty wrote to newspapers to urge politicians and ordinary citizens to intervene in situations of human rights violations. For instance the Nobel Laureate Heinrich Böll wrote "A Plea for Meddling" and brought attention to the abuses in a host of countries around the world, including his native German Federal Republic (Böll, 1973).

This new strategy of human rights was denunciatory and accusatory. Michael Ignatieff referred to this new predicament as the "advocacy revolution" where the activity of human rights organizations led to the formation of a global civil society that could take the sovereign states to task over unfulfilled promises (Ignatieff, 2000, p. 291). I am referring to a similar set of developments, albeit I understand this transformation in less epochal terms. The rise of the accusatory strategy is better conceptualized as the dissemination of new practices that mobilize a politics of accountability by exposing the discrepancies between state practice and previous commitment to principles of human rights rather than a series of acts that ushered us in a new era.

\footnotetext{
${ }^{37}$ The urgent action was issued in March 1973; in April her wife was called to the prison where she found that her husband was alive. Rossi was released in October that year. At that time many prisoners were being tortured and disappeared in Brazil (Amnesty International USA, $2011 \mathrm{a}$ ).
} 
The development of human rights platforms and media openness to the allegations of human rights advocates and expert opinion were significant conditions of possibility for this approach. Dezalay and Garth remind how the links established with the media in accusatory strategy was something that was achieved rather than readily available. They show that $\mathrm{AI}$ executives had to arrange meetings with media managers and convince them they were a neutral organization, (Dezalay \& Garth, 2006, p. 236). A significant amount of activist work was required to make things public. Media was a vital instrument to get Al's message out and the organization had to maintain an impartial standing so that its message could be picked up by the journalists. AI tried to show that it had no links to any government and were not propagating any hidden agenda by advocating the cause of victims from both sides of the Iron Curtain (Power, 1981). The organization was careful to maintain this balance in its annual reports as well. These reports mentioned abuses and concerns from almost all countries in the world and took caution to emphasize violations in both the Eastern bloc countries like Soviet Union, and in the Western camp like Turkey. This was also the reason why three prisoners were adopted simultaneously by Amnesty groups. This number reflected the partition of states in the Cold War into three groups of Western Bloc, Eastern Bloc and the Non-Aligned movement.

In terms of the historical context, accusatory strategy developed at a time when state practices around the world engaged in outright abuses and "state crimes" became more apparent. In the 1950s and 1960s, violations of human rights that were related to "counter-insurgency operations" became more apparent as decolonization unfolded. Coups and military interventions from Greece to Guatemala and racial discrimination 
fuelled the human rights struggles. Apart from racial discrimination in South Africa, civil and political rights issues absorbed most of the energy of human rights advocates. Freedom from torture and extrajudicial killings, rule of law were basic demands that the human rights community expressed from 1960s on. This was in part related to a shift in the way Western powers such as USA and France dealt with instabilities in the Third World (Amnesty International, 1973). Paradigmatic examples of these instabilities were popular insurgencies for independence (e.g. Algeria) and revolutionary uprisings (e.g. Cuba). These conflicts had their Cold War aspect, as the Soviet Union gradually supported moves for independence in the Third World and at times actively encouraged groups that undermined governments with links to the Western bloc. These kinds of situations were defined as "national emergencies" by the Western powers which ruled out both the implementation of human rights and the laws of war (Rajagopal, 2003, p. 181). The counterinsurgency doctrine also contributed to the justification of drastic law and order measures. According to this, uprisings relied on a logic of "guerilla warfare" led by a small but armed section of the population that tried to provoke the government into overreacting to guerilla actions thereby alienating the people from the government. The "success" of the guerilla, especially in the early stages of the insurgency, was in part due to its secretive character and its small size. This made it harder for conventional armies to confront guerillas. Thus, the use of torture was seen as instrumental in crushing guerilla groups by extracting information from captured persons. This would expose not only the members of the insurgent group but also their hiding places and secret depots leading to the destruction of the whole organization (Mack, 1975). 
In these years, international human rights practices began to exhibit elements of a disciplinary mechanism that deployed surveillance, self-monitoring, and punishment in the form of shaming. As mentioned above these were the primary tools available to represent and intervene in international human rights processes developed by the architects of the Permanent Mandates Commission. These practices were not only limited to the work of the non-governmental organizations. Even the relatively conservative and lethargic bodies of United Nations drifted towards functions of observation, and its corollary, shaming. In 1947, UN's ECOSOC took an explicit decision not to receive communications from victims of human rights violations. The ECOSOC reversed this with Resolution 1235 in 1967 authorizing its suborgans to receive and study situations of "a pattern of gross violations" such as apartheid. The 1503 Resolution in 1970 went further in institutionalizing a monitoring mechanism by authorizing ECOSOC suborgans to consider communications revealing a "consistent pattern of gross and reliably attested violations of human rights" (Forsythe, 1985). In 1966, the International Covenant on Civil and Political Rights was adopted by the General Assembly of the UN. Entering into force in 1976 , this covenant included a provision for the establishment of a treaty body known as the Human Rights Committee (HRC) with powers of receiving inter-state, individual (optional) complaints and evaluating self-monitoring reports sent by the state parties (UN, 1983).

This constellation was accompanied with a shift in the definition of torture. In the years after the WW2, the grim topic of torture came up mainly within the context of the genocide, and massacres tried at the Nuremberg military tribunals. Torture was defined as brutality and cruelty and usually invoked images of inquisition or Nazi repression. For 
instance in the Preamble of the UDHR, previous human rights abuses were identified as "barbarous acts which have outraged the conscience of the mankind." A 1959 commentary on the French methods in Algeria established parallelisms between Nazis and the French by referring to French DST (Direction de la surveillance du territoire, French domestic intelligence) as Gestapo (A. T-S., 1959). This imagery of torture was not surpassed in the late 1960s but fell to the background as torture came to be associated with systematicity, regularity, prevalence and government. Torture came to lose its aura of a typical Nazi atrocity although it was frequently linked to Nazi practices in the discourse. The Voltairien association of torture with barbarism functioned to obstruct the development of an analytical purchase on this act and its new conception as an instrument of government meant that it would now be easier to produce a diagnostic account of it.

Discourses of international law and human rights advocates were aligned on the basis of a new conception of torture, what I call torture as networked practice. The networked aspect of this new conception refers to the understanding that torture did not simply stem from a heinous and criminal racist ideology or conducted according to the orders of a supreme and central authority. Rather, it relied on the coordination and cooperation of different actors for its existence and maintenance. The network of torture required the collective action of a series of different actors. It should be made possible ideologically: scholars and advocates had recognized that introduction of ethnic, racial and similar differences into the body politic were a harbinger of human rights abuses. Boundaries within the population defined who were more vulnerable to torture and illtreatment (Collins, 1974). It was also recognized that the act of torture was not limited to the relations between the victim and perpetrator but was facilitated by other actors. In this 
context, the facilitating role of the medical profession was scrutinized. In 1975 both the World Medical Association and the International Council of Nurses adopted resolutions that warned against medical professional complicity in the ill-treatment of detainees and prisoners (Jesani, 1989) thereby underwriting the networked conception of torture. The role of the superpowers in condoning or facilitating torture and other abuses was also noted. US Congressman Donald Fraser promoted amendments to US legislation to make the transfer of military and internal security aid to countries more difficult where gross violations of human rights were taking place (Fraser, 1977).

The other aspect of this conception of torture is practice. Although the notion of network already contains the idea of practice, it is necessary to retain this term to emphasize pattern and repetition. A practice can be defined as "a routinized type of behavior which consists of several elements, interconnected to one other" that include forms of knowing and understanding (Reckwitz, 2002, p. 249). In the late 1960s and 1970s, torture came to be increasingly conceptualized as practice and policy. The European Court in Strasbourg coined the notion of "administrative practice" of torture in several high profile cases in these years. Administrative practice was defined in the Strasbourg judgment in the 1969 Greek case $^{38}$ as consisting of a "repetition of acts in conjunction with official tolerance" of violation (cited in Hannum \& Boyle, 1977, p. 317). An administrative practice did not necessarily mean that there was legislation

\footnotetext{
${ }^{38}$ The so-called 1969 Greek case resulted from an inter-state application brought to the European Court of Human Rights by Denmark, Norway, Sweden and the Netherlands against Greece following the coup d'état there in 1967. The four applicant governments argued that the measures that the Greek military administration took, such as suspension of some articles of the constitution, amounted to a violation of the European Convention of Human Rights. They further argued that the 1967 derogation of the Greek government from the Convention was not lawful. Other charges of torture on Greek citizens by the junta were also brought to the Court in 1968 by Denmark, Sweden and Norway. The European Commission of Human Rights ruled in its 1969 report against Greece on both counts.
} 
authorizing violations of rights in the law books of a state. Moreover, according to this jurisprudence laws banning the practice were not sufficient to demonstrate that there was not an administrative practice. The naming of a series of acts as administrative practice was important both due to its political effect of stigmatizing the state and to its legal consequences for parties to the European Convention on Human Rights. In Court's practice, the acceptance of administrative practice in a case meant that other victims of human rights violations could directly apply to the Court. That is to say, victims of human rights abuses had no responsibility to apply first to their own national authorities, such as the ombudsman or local courts. The citation of administrative practice was an acknowledgment that national institutions were not able to provide "effective remedies." This was what happened in the case launched against UK in May 1972 where Donnelly and others alleged that they were ill treated by the security forces in Northern Ireland in a systematic manner. Many detainees had previously complained from methods of interrogation used by the security forces such as hooding and sleep deprivation but despite measures by the government this practice went on. In this context, the European Commission of Human Rights pointed to the existence of an administrative practice and ruled the applications admissible (Boyle \& Hannum, 1974). The Commission later refined the definition of administrative practice by requiring toleration at the higher levels of the state for the designation of administrative practice (Hannum \& Boyle, 1977).

The notion of administrative practice should not merely be seen as a legal technicality. It was part of the transformation of the conception of torture in an era of counter-insurgency operations, dictatorships and military coup d'états. This conception of torture aligned the jurisdiction of Commission and Court with the political arguments of 
human rights advocates. The latter were arguing in the late 1960s and 1970s that torture had become an integral part of the government of the populations in many parts of the world (Amnesty International, 1973; Mack, 1975; Vidal-Naquet, 1963). It had become a "standard administrative practice... inherent in the political systems of governments" (Rosenbaum, 1975, p. 21). This emphasis on pattern of violations was not limited to the European court. Repetition and systematicity were also emphasized by other authorities and seen as a condition that required international intervention. Special Rapporteur of the International Law Commission ${ }^{39}$ opined in 1976 that "a serious breach on a widespread scale" would be considered an international crime (cited in G.D.R., 1976, p. 43). In a similar fashion, UN organs reacted to violations of human rights when they were "institutionalized." For instance, the General Assembly resolution 3448 (XXX) of 9 December 1975 expressed its distress "at the constant flagrant [emphasis added] violations of human rights including institutionalized [emphasis added] practice of torture" (UN, 1975, p. 622). Selective attention to large-scale violations applied to foreign policy initiatives as well. Human rights violations appeared in the radar of the United States foreign policy only if violations were gross in nature (Hevener, 1980).

Notions of administrative practice and its corollary systematic torture were deployed by legal experts and human rights advocates to connect different and disparate acts of abuse around the world. Yet this did not mean that torture was inscribed as a homogenous act in all instances. We can also discern the operation of disciplinary tool of differentiation in relation to the offending states. Differentiation of nation-states in international expert discourses was not limited to binary categories of complying and

${ }^{39}$ International Law Commission was established by the United Nations in 1947 to develop and codify international law. 
non-complying states. Observation of offending states produced "multiple separations, individualizing distributions" (Foucault, 1979, p. 198). Richard Bilder (1969), an expert of international law, for instance suggested a distinction between "responsible" and "recalcitrant" governments. Both categories included violators of human rights, however, responsible governments were those willing to improve the human rights situations in their country, but could not achieve this due to "unawareness, inertia, or lack of sufficient material resources or expertise to do the job" (Bilder, p. 193). The former could be corrected with technical assistance and cooperation while the problem with the recalcitrant governments that deliberately denied rights was more complex. The target of international intervention depended on the nature of the cause of rights abuse. If torture was a consequence of the commands of political leadership, pressure should be applied there. If the society was indifferent to violations of human rights then "international pressures need to reach more deeply into society and expect more gradual results" (Bilder, p. 195). The corrective punishment of intervention was determined in relation to the nature of the abusive act and the form of domestic government. This growing analytical approach in the accusatory strategy indicated that disciplinary methods were being introduced to the governance of international human rights. This is in a sense similar to the cases where competitiveness indexing of nation-states (Fougner, 2008) or ranking according to good governance (Lowenheim, 2008) are deployed to manage nation-states. In the case of monitoring human rights, expert discourses differentiated nation-states according to their degree of resistance to human rights, and capacities to enforce them. 
Global mapping of torture was not limited to journal articles by experts. International organizations were also inclined to differentiate the states according to different criteria. This differentiation, moreover, implied the tactics of intervention in the problems. For instance, Amnesty International (AI) pointed out in its landmark 1973 report that states engaging in torture should be differentiated according to their political and social systems and different approaches should be applied to them. Various hotspots of rights abuses were differentiated according to the nature of the problem. The case of Northern Ireland, where ethnic and religious identities were suppressed by a security apparatus was differentiated from the Greek Colonel's regime, where a junta took control of the state. The latter was the "worst example of torture in the world" (Amnesty International, 1973, p. 69) where no international mechanism would be effective. It was a political system based on torture so action should be taken at the states and super-states levels. Greece's colonels could give up torture only when they faced pressure from fellow states and organizations such as the Council of Europe.

The UK case posed a different challenge for AI. While the existence of torture or ill treatment was not really disputed, the problem seemed to be a problem of effective control rather than toleration. The country under question was a democratic one whose agents employed torture or ill treatment despite contrary political will and legislation. The goal Amnesty saw fit in this kind of a situation was "to make the executive realize what is occurring and then to rely on domestic procedures" (Amnesty International, 1973, p. 102). It was thought that there were regimes and governments in the world concerned about their image and prestige and hence open to constructive criticisms from human rights groups. By supplying relevant information to the public and the government, and 
establishing a dialogue, states could be governed indirectly and incidents of torture could be prevented.

Definition and criminalization of torture were important objectives for the accusatory strategy. Although the 1948 UDHR and 1966 ICPCR banned torture and assaults on personal integrity, the corpus of international law lacked a definition of torture and similar acts. This created difficulties for human rights advocates in terms of problematization of the practice and the alignment of the anti-torture forces. A working definition was provided in the Greek case of 1969. Duffy (1983) reports that the Strasbourg judges understood torture as an aggravated form of inhuman treatment with the purpose of obtaining information or inflicting punishment. Inhuman treatment, in turn, was defined as deliberate infliction of physical or mental pain. Al's 1973 Report on Torture recognized the problem of legal definition and provided its own version:

Torture is the systematic and deliberate infliction of acute pain in any form by one person or another, or on a third person, in order to accomplish the purpose of the former against the will of the latter. (Amnesty International, 1973, p. 31)

To secure a more credible basis for the accusation of torture and create a deterrent effect, human rights activists sought to internationalize the criminalization of torture. In the $5^{\text {th }}$ UN Congress on Crime on Prevention of Crime and Treatment of Offenders in 1975, Amnesty submitted a 16-page report which invited the Congress to adopt a text declaring torture as an international crime (Leary, 1979). The resolution adopted by the Congress did not specifically call torture a crime. The 1975 UN declaration on torture included a formulation similar to the above AI definition but was more forthcoming about the purposes of torture. Besides obtaining information and punishment, torture's 
function of intimidation of the general population was also included in this definition (UN, 1975, p. 624). Perhaps a significant novelty in the declaration was the expression that torture comprised "severe pain or suffering, whether physical or mental." In this way, the definition of torture was authoritatively expanded to include psychological suffering. ${ }^{40}$ In 1977 , Sweden invited the UN General Assembly to request the Commission on Human Rights to draft a convention against torture and other forms of ill treatment and punishment. The Swedish government also submitted a preliminary draft convention in early 1979 (Burgers \& Danelius, 1988, p. 31). This initiative opened the way to the adoption of the United Nations Convention against Torture and Other Cruel, Inhuman or Degrading Treatment or Punishment (UNCAT) in 1984 by the General Assembly. The draft convention proposed to make torture an international crime and as such upheld the accusatory strategy.

UNCAT retained the information, punishment and intimidation aspects of the 1975 declaration while adding a discrimination aspect to the definition of torture. While the instrument obliged the states to prevent torture in their jurisdiction (Art. 2/1) its basic approach was penal. UNCAT's underlying assumption is that criminalization of the act of torture in the respective domestic laws of the state parties, which is also an obligation of the convention (Art. 4/1), will act as a deterrent towards potential offenders or their accomplices. Furthermore, UNCAT seeks to cancel any possible safe havens for torture by making this act a universal crime: The state parties are required to either punish or extradite offenders that are present in their territories (Art. 5/2). In this way the act of

\footnotetext{
${ }^{40}$ It is possible to say that this declaration enhanced the tendency in international law to ban state practices that led to mental suffering. Mental harm was mentioned in the 1948 Convention on the Prevention and Punishment of the Crime of Genocide, as well as the 1973 International Convention on the Suppression and Punishment of the Crime of Apartheid (UN Commission on Human Rights, 1986).
} 
torture was elevated to the same status as piracy or slavery in international arena, it became a universal crime.

UNCAT incorporated aspects of a disciplinary technology of surveillance by establishing a body responsible for monitoring the performance of states, hearing allegations of torture and "trying" the state party. The Committee against Torture would be composed of ten expert members elected by the state parties. Similar to the Permanent Mandates Commission of LoN, the Committee would audit the performance of the states parties on the basis of self-monitoring reports. The Committee was also authorized to receive "reliable information" with "well founded indications" concerning infliction of systematic torture in the territory of a signatory state. In this case, Committee would invite this country to examine the information and submit its observations. This procedure could lead to a confidential inquiry by experts of the committee with the possibility of a visit to the territory of the country under question. Although the inquiry itself and the report is confidential, the Committee could decide to publish its findings in a summary form in its general annual report, thus effectively judging whether there was systematic torture or not in the country. This international disciplinary mechanism was certainly limited in many aspects. Its surveillance was not strictly ex officio in that it not only relied on the self-reporting mechanism but also its initiative of inquiry required reliable information and systematicity of torture.

The establishment of a legal definition of torture, criminalization of the act and the dissemination of the surveillance of state practices can be counted as the "achievements" of the accusatory strategy. However, the strategy had its own limits. Soon some advocates of human rights began to criticize its denunciatory style, penchant 
for controversy and confrontational style with governments. These criticisms prepared the ground for the proposition of alternative techniques, which are the subject matter of the next section.

\subsubsection{The Preventive Strategy}

While the accusatory strategy was predominant in the late 1960s through early 1980s, the preventive strategy was articulated in the 1970s and took a more humble position in the face of growing violations of basic human rights worldwide. It should be noted at the outset that this difference in strategies used by human rights agencies did not mean that these agencies were rivals of each other. In many instances, key people in the movement did not have any difficulty in moving from one strategy to another. Human rights activists were well aware that they were working for the same objective of strengthening human rights around the world. Human rights groups with different strategies such as AI and Swiss Committee against Torture (SCAT) sometimes even supported the same international initiatives and legislation despite differences in strategy. Nevertheless, proponents of what I call the preventive strategy sought to differentiate themselves organizationally. For instance SCAT chose not to be associated with an action network as it thought that this could jeopardize its chances for convincing the states to adopt preventive mechanisms (Association for the Prevention of Torture, 2007, p. 11). ${ }^{41}$ Rather than incriminating the offenders, proponents of this strategy sought more "practical" and immediately "effective" ways of preventing human rights violations.

${ }^{41}$ The network in question was "SOS Torture" which was established following a SCAT-sponsored 1983 conference of experts seeking to devise a global strategy against torture. The SOS Torture was designed as a global communication network between human rights NGOs to denounce cases of torture and share information. SCAT refused to become part of this organization which included Amnesty International and International Commission of Jurists. In 1986, SOS Torture became the World Organization Against Torture (Association for the Prevention of Torture, 2007, pp. 10-11). 
They problematized the approach of other activists and pointed out that tactics of monitoring human rights performance and shaming violators was ineffective, lengthy and politicized.

The differentiation of strategies was explained in a booklet prepared by the SCAT in 1977. This Committee was established with the initiative of a Swiss banker and lawyer, Jean-Jacques Gautier, who decided to commit his time and resources to combating with torture after his retirement (Association for the Prevention of Torture, 2007). Gautier problematized extant instruments and the UNCAT which was then still a draft convention:

Procedure is extremely time-consuming... state is put in the dock; it must be given the rights of defense.... Faced with such a serious accusation, the State charged will do everything to avoid condemnation or even an inquiry on its soil.... Hence, the case becomes greatly politicized. (Gautier, 1979, p. 26) Gautier thought that rather than engaging in a long process of inquiry into cases of torture, international community should undertake visits modeled on the example of International Committee of the Red Cross. This organization was active for many years and was authorized to visit places of detention and record the condition and complaints of prisoners in both international and intra-state conflicts. The ICRC was doing its job, successfully according to Gautier, under conditions of conflict and war. The incidence of torture was most of the time taking place in less dramatic times. With this purpose, Gautier initiated the preparation of an international covenant to prevent torture. Originally proposed as the Convention against Torture the draft was later withdrawn to avoid loss of political energy and competition with the Swedish draft of UNCAT. There 
were concerns that Swiss proposal was too ambitious and could kill the whole momentum behind the adoption of a binding international document against torture (Evans \& Morgan, 1998). Gautier stated that his proposal would have several advantages over other conventions. It would emphasize a regularized observance of human rights abuses, a spirit of cooperation between states and human rights agencies, and immediate intervention in problems:

Instead of dramatic enquiry, routine visits..., instead of a charge made against a State, a system of mutual assistance and collaboration to improve the protection of prisoners..., stress will be laid on prevention..., possibility of swift action. Instead of clashes between governments, a nucleus of committed States in the fight against torture... (Gautier, 1979, p. 28)

It was clear that Gautier was frustrated with the denunciatory style human rights advocacy. But rather than targeting human rights organizations that utilized this technique, he focused his criticisms on the United Nations bodies, which represented all the negative aspects of the accusatory strategy. He not only opposed the dramaturgy of inquiry that underlined the authority of international community but also drew attention to the inter-state fighting in such human rights committees, to the endless exchange of accusations. He advocated focusing energies on states where promotion of human rights could succeed. In so doing, Gautier pushed the preventive strategy towards a pragmatic ground and opened the way to the exercise of what Peter Redfield called "triage," that is "a system of prioritization based on the facts of suffering" (Redfield, 2008, p. 197). By emphasizing "a nucleus of committed States," Gautier directed the energies of human rights advocacy towards soft cases where torture and ill treatment seemed more 
preventable. Utilizing this notion, we can say that Gautier did not suggest sacrificing certain citizens for the sake of others on social, political, or religious grounds but that he introduced a system of "dispassionate separation and a pragmatic focus on immediate action" (Redfield, p. 197).

Later, with support from NGOs such as $\mathrm{AI}$ and International Commission of Jurists, the SCAT draft was turned into an optional convention to the UNCAT. Although human rights defenders were careful not to pit the latter against the optional convention and support was provided for both legal instruments, the competition between the judicial and preventive logics of the two conventions could not be ignored. When the negotiations at the UN lagged on and no approval of draft UNCAT was in sight, Council of Europe (CoE) Parliamentary Assembly (1981) took an initiative to explore the option of adopting SCAT draft as a European convention. In the report of the Legal Affairs Committee, it was pointed out that:

Although [torture] is condemned by international declarations and conventions, its characteristics make it very difficult to prevent and suppress... The most important advantage of the draft is that it does not create the possibility of public attacks or accusations against the government concerned... (Council of Europe Parliamentary Assembly, 1981, p. 3)

When the draft European Convention for the Prevention of Torture and Inhuman or Degrading Treatment or Punishment was adopted and a European Committee for the Prevention of Torture and Inhuman or Degrading Treatment or Punishment (CPT) was established under the auspices of $\operatorname{CoE}$ in $1989,{ }^{42}$ it became a durable alternative to the

\footnotetext{
${ }^{42}$ The Convention itself was adopted by CoE in 1987 , and entered into force in 1989.
} 
accusatory approach. Yet, these two different approaches to human rights abuses should not be taken as strictly exclusionary. Human rights defenders did not hesitate to utilize both instruments in their actions. Besides, the success of the preventive approach most of the time rested on the "threat" of condemnation in cases of "systematic" abuses by publishing the reports prepared based on visits to the places of detention.

The possibility of swift action was an important asset for the proponents of preventive strategy but it was not the only difference. This strategy had a different conception of torture and the state. In this respect, remarks by Manfred Nowak, is quite telling. Nowak has been an important figure in human rights community and he acted as the UN Special Rapporteur on Torture between 2004 and $2010 .{ }^{43}$ Reflecting on his PhD studies at Columbia University in early 1970s, Nowak points out that "torture was for me something completely unimaginable, an act of barbarity which belonged to the dark history of the Middle Ages and which could only be invented again by the perverse minds of people like Hitler, Stalin and Pinochet" (1998, p. 247). Nowak said that the natural corollary to this kind of conception of torture was the belief that, international community could eradicate torture by struggling against these "evil tyrannies." $\mathrm{He}$ pointed out that in the 1970s, there emerged a new and "more realistic" approach in the human rights community (p. 248). Instead of fighting against impunity, this new approach embraced "non-judicial and non-accusatory" (p. 249) methods for preventing human rights abuses. Indeed, the notion of torture entertained by human rights groups such as AI was very much centered on the idea of cruelty and barbarity. Although AI had no illusions that modern torture was different from the medieval rack in many ways, its

\footnotetext{
${ }^{43}$ The post of the Special Rapporteur was created in 1985 to examine questions relevant to torture. Its tasks included writing fact-finding reports and transmitting urgent complaints of torture to relevant states.
} 
accusatory strategy necessitated a focus on the pain inflicted by torture. For instance in a 1984 publication AI referred to torture thus: "Concentrated in the torturer's electrode or syringe is the power and responsibility of the state" (Amnesty International, p. 4). Hence, it frequently used images of pain in its reports.

The way preventive strategy conceptualized torture can be clearly seen in the general and country reports of CPT compiled in a recent publication (CPT, 2010b). ${ }^{44}$ In its Second General Report, the CPT indicated that "ill treatment can take numerous forms, many of which may not be deliberate but rather the result of organizational failings or inadequate resources" (CPT, 2010b, p. 15). Contrast this with the conception of torture found in the discourse of the accusatory strategy which often understood it as a deliberate and systematic infliction of pain. CPT invoked ideas such as bureaucratic capacity and resources to refer to incidences of torture. In addition to inviting a different kind of reaction to torture, this conception also expanded the range of things that should be examined to prevent torture. That is to say, unlike in the accusatory strategy, the political will of the governments was not a prime consideration. The focus was on more mundane facts such as the condition of facilities, training of the officers, availability of technical equipment and so on. Thus the committee declared that "the overall quality of life in an establishment is therefore of considerable importance to the CPT" (CPT, p. 15). In line with this understanding, the reports of the committee are full of references to

\footnotetext{
${ }^{44}$ The country reports are drawn up by the CPT following each inspection visit whereas the general reports are prepared annually to communicate the work of the Committee. In the general reports, the CPT did not limit itself to communicating its work but sought to develop and promote standards of detention although the Convention did not originally include such a mandate or task. That is to say, the CPT deducted some general principles from its recommendations to specific states, thereby rendering its suggestions more mobile and applicable across all parties of the convention. This practice is also notably similar to the standard setting activity of Permanent Mandates Commission. Despite lack of clear guidelines in the Convention, the CPT develops certain standards just like PMC did in its supervision of mandate territories.
} 
standards for cell sizes, dormitory spaces and other facilities. For instance the CPT pointed out that cell size should at least be nine square meters for two people and prisoners should have eight hours per day for out of cell activities (Morgan, 2000a). This indicates a recognition that torture and ill treatment is not necessarily an "action" by a public official but could result from the technology of detention which is torture "made durable" (Latour, 1991b). Additionally this strategy transformed the idea of prevention, which was a key word for human rights community. Rather than a criminological notion of prevention based on deterrence with punishment, early identification of offenders or avoidance of repetition, this strategy was based on prevention in part through shaping the material environment, which, if ill-designed, could amount to ill treatment (cf.

Brantingham \& Faust, 1976; Evans \& Morgan, 1998). This shift of attention from action to conditions also modified the definition of ill treatment as understood by the CPT. One such condition is the use of solitary confinement by authorities to aggravate punishment or to discipline the prisoners. In its report CPT asserted that "solitary confinement can, in certain circumstances, amount to inhuman and degrading treatment" (CPT, p. 18).

These two strategies had different images of the state. As mentioned above, the accusatory strategy emphasized the systematicity of torture, its connections to the government and the importance of political will of the state to eradicate torture. Preventive strategy, however, expounded another analysis by distinguishing states according to their relationship to torture. Gautier "calculated" that in $40 \%$ of the states either ignored or tolerated incidents of torture in its jurisdiction while $20 \%$ used it as a means to govern (Association for the Prevention of Torture, p. 2). It appears that the preventive strategy principally aimed at this $40 \%$ portion that did not rely on torture as a 
government policy. It was implicitly recognized that governments could not always be expected to have an effective control of all the functionaries of the state, especially at times of heightened political and social tensions. Furthermore, the cooperation of the law enforcement agencies with the government cannot always be assumed. This implied that political will, one of the first things NGOs look for in cases of human rights abuses, was not sufficient for eradicating torture.

The preventive strategy against torture prepared the ground for and later merged with capacity building programs to prevent torture and ill treatment. These programs emerged in the aftermath of "transitions" in former dictatorships in Latin America but their dissemination was mostly due to the end of Cold War. Larry Diamond, an expert from Hoover Institution with links to the National Endowment for Democracy, ${ }^{45}$ argued in the pages of policy-oriented Foreign Policy journal that this period provided a great opening: "not since the end of the World War I has the West had such an opportunity to shape the political nature of our world. By promoting democracy abroad US can help bring into being a world composed of stable democracies" (1992, p. 27). Especially in Eastern Europe, the Warsaw Pact system was more or less peacefully being replaced with formal democratic and market oriented regimes. However, these regimes, Diamond argued, did not have sufficient capacity to cope with challenges and transition could be reversible if it was not assisted by the Western powers with training and technical assistance. According to Diamond, this new initiative required a new outlook to international aid. No longer were the state-to-state assistance procedures sufficient. Democracy promotion required a new class of professionals equipped with not only

\footnotetext{
${ }^{45}$ National Endowment for Democracy was established in 1983 by personalities close to the Reagan
} administration. Reagan himself announced the establishment in 1982, in a visit to UK (Guilhot, 2005). 
political expertise but also local languages, "intimate knowledge of each country and sensitivity to its culture" (Diamond, p. 38).

The emphasis on capacity building was not confined to the pages of Foreign Policy journal. International legal experts were also proposing a "management approach" for a wide array of international political problems including human rights. In their oftcited article, Chayes and Chayes (1993) drew attention to the fact that non-compliance with rules of the international system could result from a lack of capacity, effective regulatory apparatus, bureaucratic capability or fiscal resources. The authors drew a picture of an international system where states usually acted in accordance to rules and norms and failure to do so was not necessarily attributable to an intention of violation. Prioritization of domestic capacities for consolidation of reform was also acknowledged by the European Union. In its stipulations of conditions for potential members (Copenhagen Criteria) the European Council underlined that "membership requires that the candidate country has achieved stability of institutions guaranteeing democracy, the rule of law, human rights" (European Council, 1993p. 13). This conclusion reflected the EU methods of capacity building that was rigorously pursued in the enlargement process (Dimitrova \& Pridham, 2004). With regard to the improvement of human rights, the capacity oriented disciplinary techniques were applied to the law enforcement agencies in the form of "human rights training" (Spector, 1997). Preventive strategy thus opened the way towards greater utilization of expertise in human rights practices.

\subsection{Conclusion}

This chapter has provided a genealogy of human rights struggles by tracing them back to the Enlightenment. It is possible to make three sets of conclusions. First, we have 
seen that torture has been conceptualized and problematized in different ways through out history. This historicity is evident in the shifts in the conceptualization of torture from the $17^{\text {th }}$ century on. When torture is seen as a problem or practice that has always existed in human history, the observer risks missing the transformation of the ways in which torture came to be perceived. The Enlightenment Philosophes had a hypothetical notion in terms of its causes and manifestations which made possible the suggestion that abolition was sufficient to fight against torture. We have seen that, as the procedures of production of knowledge changed, this notion was supplanted with a more "scientific" understanding of torture. While the accusatory strategy underscored the need for information for proper campaigning and shaming, it retained a notion of torture that invoked images of barbarity. Finally, the preventive strategy came to rely on a conception of torture that was less magisterial and thus expanded the scope of monitoring to include not only actions but also conditions as well.

Second, we have seen that today's human rights practices have a history of their own which are indeed composed of different techniques that are not inherent to human rights. For instance, I have shown that public mobilization for human rights causes was invented by the Enlightenment philosophers like Voltaire who did not find an already existing "public sphere" in Europe, but sought to build it through certain means such as writing pamphlets, making "victims" (such as Jean Calas' widow) and fundraising for them. Besides emphasizing the historicity of human rights practices, these investigations have shown that these practices are indeed composite entities. For instance, practices to monitor human rights are composed of not only norms like the protection of bodily integrity, personal freedom and so on but also procedures to produce truth, which derive 
from the relationship between power and knowledge. Consequently, human rights monitoring cannot simply be taken as an autonomous outgrowth of human rights struggles.

Thirdly, the chapter focused on the invention of a series of techniques in the League of Nations. We have seen that from the $20^{\text {th }}$ century on human rights practices borrowed many elements from international supervision and examination, although the latter was developed as technologies to secure the conduct of mandatory states and mandated populations. In other words, technologies which have been used to reproduce colonialism in new forms were later articulated with the cause of human rights. This investigation not only helped me to follow the history of human rights practices, but also substantiate my claim regarding the composite nature of human rights practices. Together, these conclusions contributed towards a genealogy of human rights practices. It should be pointed out that these three strategies are distinct but not completely autonomous. The strategies are interactive and co-constitutive. Historically, strategies were at least partially responses to previous strategies and it would not be possible to make sense of a strategy without thinking about its alternatives. The normative and consensus-seeking aspect of the constitutional strategy is always in the background even when the activists or experts are using the accusatory and preventive strategies. That is to say, the accusatory and preventive strategies presume that human rights constitute the normative basis of their action. This consensus on human rights is often also cited as the main motivation of their work. But the relationship between strategies is not always supplementary and they are not always compatible. The accusatory strategy constituted a response to the moral elitism and Cold War politics of the constitutional strategy by 
seeking to mobilize "ordinary" people to write letters of protest to heads of state or government. It also sought to breach the East/West dichotomy by emphasizing human rights abuses in both camps in its reports. Its naming and shaming tactics, moreover, are not compatible with the "respect for national sentiment" found in the constitutional strategy. The preventive strategy, in turn, sought to establish itself as an effective and non-judicial alternative to the accusatory strategy. It is possible to assert that the appeal of the preventive strategy was in part due to the fact that it was more low-profile. That is, it operated without mobilizing the press corps and often kept confidential the information regarding human rights abuses of a state. Due to these features, it was a more acceptable strategy for state actors than the accusatory strategy. The preventive strategy did not operate in a vacuum. The shaming and naming tactics of the accusatory strategy lurked in the background and this "threat" rendered preventive strategy a more plausible choice or a lesser evil for state actors. Engagement with the preventive strategy also afforded the state actors a defense against the naming and shaming tactics. It meant that at least they were "doing something." Preventive strategy seeks to prevent torture through gaining the allegiance and winning the support of police officers. Punishment or formal negative sanctions (other than rare public declarations in the case of CPT) are not compatible with this strategy as this strategy seeks to build up consent. Therefore, simultaneous implementation of an accusatory strategy with a strict regime of punishment and discipline towards police abuses along with a preventive strategy would be extremely difficult, if not impossible.

In the last sections, the analytic of strategy provided a fruitful way of analyzing human rights struggles by focusing on their logics, techniques and privileged subjects. 
We will again pursue similar themes of in the later chapters. But, before doing that we need to understand how Turkish state conduct became an object of problematization. Without this problematization, the implementation human rights strategies on Turkey would not be possible. The next chapter seeks to make this process intelligible. 


\section{CHAPTER 3: HUMAN RIGHTS AS A POLITICAL PROBLEM IN}

\section{TURKEY}

Most observers of Turkish politics agree that Turkey, at least until recently, had a dismal human rights record. Yet the truth of this statement has not been so apparent until the late 1970s. Until that time, Turkish foreign policy makers were able to maintain an image that was pro-democracy and pro-freedom by utilizing human rights rhetoric. It is also possible to assert that the Turkish elite saw commitment to human rights at the level of principles as a matter of reaffirming Ankara's place among the "civilized nations" of the world. Turkey was among the 48 states that approved the Universal Declaration of Human Rights (UDHR) in 1948 and one of the early members of Council of Europe ${ }^{46}$ Its legal culture has been a recipient of European ideas of "rights of man" at least since the 1839 reforms in the Ottoman Empire. The first Ottoman constitution of 1876 recognized basic personal freedoms and banned torture. In the early years of Cold War, Turkish governments have identified the country with the "free world," allied with United States and NATO. Even the leaders of the coup d'etat in 1960 referred to human rights in their first public memorandum announced on the radio. In short, the notion of human rights has been one of the basic themes in the state discourse. Nationalism, secularism, modernization and centralization of administration formed the main dimensions of what Yegen called the "Turkish state discourse" (Yegen, 1999, p. 560). Moreover, in the state discourse, the human rights were understood as part of the Westernization projects, hence, a set of values that the state necessarily identified with.

\footnotetext{
${ }^{46}$ The Council of Europe was established on May 9, 1949 and Turkey became a member on August 9, 1949. The council regards Turkey as a member country (Council of Europe, n.d.), while Turkish officials insist that Turkey is one of the founding members (Euractive Turkey, 2010).
} 
For the Turkish governments eager to maintain a respectable image of the country abroad, things began to become difficult especially in the 1970s. After the military intervention in 1971, armed action of militant groups, massacres, and ill treatment have become widespread. In the aftermath of the 1980 coup, torture and ill treatment has become even more prevalent and reported by human rights activists. In view of the relationship between the suspension of normal political life and frequency of ill treatment, the assertion of Giorgio Agamben concerning "state of exception" significantly resonates with the case at hand (Agamben, 2005). ${ }^{47}$ Several times in the history of democracy in Turkey, the army exercised sovereign power by suspending the normal rule of law in the name of a future peaceful order. Disruptions of democracy through declarations of emergency have created "zones of anomie" (Agamben, 2005, p. 50) where legal protection of the person was eliminated. Prison cells, detention centers, streets and rural areas that have been rendered as theaters of operation reducing the life of suspects to what Agamben (1998) called "bare life," persons whose biological existence could be put into question without legal responsibility. This has been true not only for periods of emergency law but also for many cities in the southeast of the country where “emergency rule" (olağanüstü hal) was in effect between 1987 and 2002.

While the concepts developed by Agamben provide significant insights for understanding human rights abuses, this chapter does not pursue an analysis of the configurations of human life under exceptional political conditions. In line with the

\footnotetext{
${ }^{47}$ The notion of "state of exception" is not the only theoretical perspective available to understand torture in a liberal political formation. As Krasmann (2011) argues, freedom and security are complimentary as security is justified on the basis of freedom and vice versa. But, Krasmann notes, security also operates on the basis of exclusion which can pave the way to "extralegal" activities such as torture. In the preemptive reason of security, the threats are uncertain and call for an absolute will to know. This will to know opens the way for torture as a source of information.
} 
theoretical points set forth in the introduction, the main purpose of this chapter is to analyze the political rationalities regarding torture. Rather than focusing on the mentalities that make torture possible, I focus on how torture came to be understood in the political imagination as a problem. This also includes the examination of measures regarding torture in Turkey and the political thought that informs these measures. The phenomenon that Agamben describes will be referred to from time to time mainly as a shorthand for describing the conditions of violations.

This chapter seeks to accomplish two tasks. First, an overview of recent Turkish political history is given to provide a background to human rights practices in Turkey. I stress the changing official conceptions of human rights and how the latter, once a symbol of identification with the West, was turned against the governments by non-state organizations and international experts. In line with the framework provided in Chapter 2, I argue that torture in Turkey has been problematized initially mainly within the context of an accusatory strategy. International and domestic actors utilized Turkey's commitment to human rights as a pad to launch their attacks on state practices. Second, I survey the emergence of torture as a problem in official thinking and how it evolved throughout time. This survey shows that the accusatory strategy of the activists was a concern for the state actors and led them to develop means to combat the allegations. It also suggests that in the early 1990s there has been a shift in the way torture was conceived by state actors making possible the adoption of new projects to tackle practices of torture. In this period, the combat against allegations were largely overlaid by a new official thinking that sought to find ways of preventing torture by the police. 


\subsection{Turkey: an Overview}

The Republic of Turkey was founded in 1923 on the ruins of the Ottoman Empire. The last hundred years of the empire has been characterized by military, legislative and administrative reform attempts modeled after European states and were motivated in part by the idea that modernization of the state was necessary for its survival. A second motive for the modernization and consequent introduction of the rule of law and safeguards for security of all Ottoman subjects including the non-Muslims was placating the French, British and Russian publics concerned about Christian populations in the empire. The Ottomans required the alliance of these countries in order to be part of the European state system and secure the sovereignty of the empire (Hanioglu, 2008). The imperial period was ended with the outbreak of WW1 and the establishment of the Republic, which replaced the Ottoman subject/ruler relation with a citizen/state relation by promising to guarantee the rights of all citizens in the Treaty of Lausanne in 1923.

The new regime under the leadership of Mustafa Kemal Atatürk embarked on a rigorous project of top-down modernization by application of radical reforms such as the abolition of the Caliphate, introduction of laicism, a new Constitution, universal suffrage and a new political identity based on Turkish nationalism. The Republican People's Party (RPP), led by Atatürk, firmly held the state apparatus through a fusion of the party and the state. Although the Kemalist leadership controlled all aspects of the state, in the late 1920s it also experimented with some measures to relax the control of society and organized the establishment of a liberal "opposition" party. Yet these measures proved to be short-term when government realized that it still did not have a firm foothold among the population. 
During the WW2, Ankara had adopted a posture of "active neutrality" (Deringil, 1989, p. 133) that was abandoned only in late 1944 when Allied victory became apparent. Turkey declared war against Germany and Japan in February 1945, when this was stipulated as a precondition for participation in the United Nations Organization at the Yalta Conference (Aybay, 2002). The ruling RPP and its "national chief" İsmet İnönü saw that the single-party regime was increasingly becoming an anachronism in the postwar world and constituting an obstacle to the development of meaningful relations with Western countries. This led to a renewed attempt at liberalizing the regime through allowing the establishment of an opposition political party. In 1946, the Democrat Party (DP) was established by ex-MPs of the RPP following disagreements with the government. The notion of "human rights" entered Turkish political discourse in this process of aligning with the new global political status quo. In the same period when this rupture occurred in the ruling party, a group of intellectuals and public figures established a Human Rights Association in Istanbul. Yet the RPP government was not intent on relaxing its hold on the Turkish political scene. Some radical groups were already effectively liquidated from the political arena. Soon, the association was targeted by the government, as it could become another focal point for the articulation of opposition against its power. Moreover, the RPP government was aware of the legitimacy this concept enjoyed and used the means at its disposal to pacify the Human Rights Association (HRA) and attempted to monopolize the issue by establishing its own human rights association (Tinal, 2000). ${ }^{48}$

\footnotetext{
${ }^{48}$ The government did this by establishing an official HRA of its own in Ankara and started a smear campaign against the other association. Members of the HRA were pressured to declare that they had no links with the organization. Inönü later referred to this episode as "our first fight against communism."
} 
Allegiance of Turkey to the Western powers was seen as necessary in the context of the Cold War to guarantee the survival of the state. Turkish anxieties of territorial integrity were heightened after the end of the WW2, when Soviet Union made several "demands" concerning its borders with Turkey and the international legal framework regulating the passage from the Turkish straits of Dardanelles and Bosporus. The attitude of Soviets towards Ankara had led the political leaders to look for international support and guarantees. From the Turkish point of view, United States was the obvious candidate for this role. However, Washington's reluctance to extend security or political guarantees to Turkey was dropped only after the advent of Greek Civil War in the 1940s. The proclamation of Truman doctrine in 1947 effectively included Turkey in the Western camp, something that Ankara was asking for a long time. After this proclamation, United States increasingly emphasized Turkish democracy as a bulwark against Soviet communism. Truman even announced a message on the $25^{\text {th }}$ anniversary of the establishment of Republic of Turkey: He congratulated Ankara for "the decision of the Turkish nation to continue the development of democratic institutions and to further safeguard human rights and liberties..." (as cited in New York Times, 1948, p. 4). Alignment of Turkish and American human rights language has become more evident after the end of "monoparty period" and rise of the Democrat Party (DP) to power in 1950 (Erogul, 1987). The participation of Turkish forces in the Korean War (1950-1953) and Turkey's membership in NATO in 1952 underwrote the close relationship between the two countries which was affirmed with the Turkish President Celal Bayar's visit to the US and his speech in the Congress in 1954. Both American and Turkish rhetoric placed Ankara in the camp of "freedom-loving nations." Human rights 
and liberty in a polity was understood as values that united the world and Turkey on the same basis. The New York Times reporter Peter Kihss (1954) quoted President Bayar's words thus:

The chief element of the Turkish revolution relating to human rights is the abandonment of a sectarian concept of law based partly on religious foundations and the adoption and assimilation of a concept of law, the principles of which are common to the nations of the free world. (p. 1)

Circumstantial evidence from the relations between American and Turkish lawyers in the 1950s suggests that the constitutional strategy of securing Turkish democracy through legal profession was in place. A case in point is the establishment of the Legal Research Institute in the Turkish capital as a result of the agreement between Turkish Ministry of Education and the International Cooperation Administration ${ }^{49}$ of the US Department of State (Redden, 1957). The University of Ankara and the New York University were also parties to this agreement. Several American professors of law were appointed to the Institute with a view to "survey legal profession in Turkey, organize a program of research, publication and continuing legal education" (Redden, p. 1111n2). One of the professors appointed, Redden, asserted that as the Cold War continued "ties between free nations" should be strengthened (Redden, p. 1111). In a conference jointly organized by American and Turkish lawyers in 1954, the American Co-director of the Institute, Delmar Karlen, argued that it was only natural for two countries who were cooperating militarily and economically and who shared the common ideals of protecting human freedom and dignity to establish a joint institute (Milliyet, 1957).

${ }^{49}$ The International Cooperation Administration was the forerunner of the US Agency for International Development (USAID). 
The rule of the DP came to an abrupt end in 1960 when the army took over the government in a "bloodless" intervention. The movement was justified with reference to political instability and internecine conflict. The armed forces addressed the nation on the radio, promising "to remain completely loyal to United Nation's charter and principles of human rights" (as cited in Oron, 1961, p. 433). The 1961 Constitution, prepared by a committee of liberal constitutional lawyers appointed by the military following the coup, provided for a relatively permissive framework for the multiplication of political and social organizations in the country. This was possible in part due to the opinion of the armed forces that the 1924 constitution did not provide any system of checks and balances and gave the party in power too much discretion. Coupled with the industrialization that led to a significant increase in the working class population in Turkey, this period saw a heightened social mobilization spurred by trade union and student movements. Student and trade union activists had a broad social justice agenda influenced by socialist and nationalist ideas. However, the right wing populism was electorally more potent in this era. Prime Minister Süleyman Demirel came to power in 1965 leading a populist right-wing government, and took a harsh stance towards the left leaning opposition seeking to attract local and international support with his anticommunist rhetoric. The military, which had become a force that had to be reckoned with for the government since the 1960 coup, was also displeased with the rise of left-wing activism in the country. In the Cold War context, such activism was seen as a threatening domestic communist insurgence and led to the reorganization of the security sector. The establishment of MIT (Milli Istihbarat Teşkilatı/National Intelligence Organization) and 
reorganization of Turkish stay-behind army forces known as the Special War Directorate (Özel Harp Dairesi) took place in this period. ${ }^{50}$

At the beginning of 1970 s, the country was undergoing a period of political instability. Many left-wing groups turned to urban guerilla tactics while the right-wing groups maintained a campaign of intimidation against left leaning trade union and student activists. Parliamentary politics was reduced to filibuster with the weakening of Demirel's political party. The government failed to stem the rise of violence on the streets while parliamentary arithmetic did not allow it to pass any legislation. This radicalization and paralyzation provided the ground for a second "successful" military intervention in 1971 in the form of an ultimatum from the Chief of General Staff of the armed forces addressed to the President. Known as the 12 March Ultimatum, the memorandum demanded the formation of a technocratic government to overcome political instability. The move led to the resignation of the Demirel government and the formation of a "reform government" headed by an independent MP as prime minister.

\subsection{The 1971 Coup and the Emergence of Torture as a Problem}

Unlike the 1960 coup, the 1971 intervention did not take over the administration of the country and preferred to maintain the appearance of a civilian administration. The parliament was not closed down. There were indications that the ultimatum was delivered partly to "forestall" internal army cliques formed by junior commanders to take power in a 1960-like coup d'etat (Zürcher, 2004, p. 258). Besides this, the intervention aimed to

\footnotetext{
${ }^{50}$ Stay-behind armies were secret organizations established in European countries during the Cold War. Inspired by the subversion operations in the WW 2 and established by the European military intelligence services, secret armies composed of trained civilians or military personnel who would organize resistance in the case of a takeover by local Communist parties or invasion by the Soviet Union. The activities of the network were coordinated by NATO. The necessary equipment, including arms, was concealed in underground arms-caches. Arguably, the Turkish stay-behind army later assumed tasks of counter-terrorism and was involved in massacres and torture (Ganser, 2005).
} 
amend the 1961 constitution and the framework it has provided for autonomous institutions, freedoms of association and expression seen as the culprits of the political and economic instability. The armed forces pressured the parliament and the new government of technocrats to amend the constitution. The high command of the army was mostly concerned with the activities of left-wing armed groups, which they saw as fifth columns or an extension of international communism. In April 1971, the National Security Council (NSC) declared martial law in 11 provinces. This was used by the armed forces not only to seek out armed militants but also round up left-wing and liberal public figures. This campaign accelerated following the killing of the Israeli consul by a leftist group; around 5000 people were arrested including scholars, left-wing political party members and trade unionists.

It was in this period that the reports of torture appeared in the first pages of mass circulation newspapers and writers began to question practices of ill treatment. It was not that torture was non-existent before the 1970s, but it was largely absent from the public and political discourse. In a sense, then, torture and ill treatment now became "known objects" as Hunt and Wickham (1994, p. 78) would call them. ${ }^{51}$ They slowly emerged as phenomena that public and political actors sought to manage in various ways. One of the first concerns of those worried with the rise of this object was credibly establishing its presence and significance. Lawyers and intellectuals supported the victims and made their plight public yet they did not make direct and outright claims of political

\footnotetext{
${ }^{51}$ Hunt and Wickham (1994) define governance as any attempt to govern a known object. These objects can include events, relationships, inanimate objects, etc. Knowing and governance are closely related and we know the objects through attempts at governing them. Similar to Foucault's use of the term government, Hunt and Wickham employ the term governance broadly. Governance includes self-governance, political government and regulation.
} 
accountability for torture. For instance a report by the Bar Association wondered whether torture on suspects has become a widespread social problem. The report conceded that "torture and beatings" (as cited in Milliyet, 1974) were a problem in many countries including Turkey but the spreading of this practice raised the question of political and administrative responsibility. Coming few years after the military memorandum, the response of the Bar Association was significant yet the language of the report and its acceptance of torture and ill treatment as "normal" betrayed the lenient attitude of the organization towards state actors. A book published around 1974 also reflected a similar tone (Samli, 1974). Another aspect of the anti-torture discourse was its definition of this practice as cruelty committed by handful of reactionaries condemned to vanish from the scene of history. Briefly put, even the advocates of victims saw recent spread of torture as a temporary aberration of security personnel. State officials, on the other hand, responded to these reports with a "White Book" of their own called "Turkey's Realities and Terrorism." In the book, allegations of torture were defined as parts of universal communist tactics aimed to "break the willingness of security forces" (as cited in Samli, p. 26). This official position also highlights the geopolitical context of the torture question. By attributing the allegations to the "communists," the official position characterized Turkey as yet another front in the Cold War between the West and international communism. This move was meant not only to isolate the human rights activists from the Western world but also call on the latter to lend political support to Ankara in its fight against the subversives.

As the Turkish Bar Association put it, torture already existed in the country. Besides torture becoming a new "known object," the character of torture incidents also 
seems to be different. The new victims of torture were mostly intellectuals and activists rather than petty criminals. This puts the cases of torture in the 1970 s into the category of what Darius Rejali calls the "national security model" (Rejali, 2007, p. 46). This type of torture incidents occur mainly due to the inability or unwillingness of the political elites to manage a national crisis, making it possible for the national security bureaucracy to take the matter in its own hands. Rejali points out that in cases like the French campaign in Algeria (1954-1962), Turkish handling of Kurdish insurgency and elsewhere, the main victims of torture are political opposition figures and torture is often deployed as part of a "proactive strategy to combat an enemy in an emergency" and to extract information regarding political activities (Rejali, p. 49). This model of torture is different from the juridical model where torture arises due to excessive reliance of the judicial authorities on confessions or the civic discipline model where the usual suspects of the population (such as vagrants, ethnic minorities, etc.) are easily subjected to torture due to their second class citizenship status. In the civic discipline model, torture and ill treatment is used as a tool of intimidation in maintaining "public security" against marginalized sections of the populations.

Official reaction to the 1971 coup from the Western countries was not harsh. The maintenance of a parliamentary façade and the fact that the suppression was mainly directed at the leftist opposition softened the stance of Cold War allies of Ankara. United States seemed to be content with the situation as it enjoyed good relations with the army. It hoped that the intervention could stop the deterioration of security situation in Turkey, which was threatening American interests. The initial reaction from the European Economic Community was varied. The EEC did not then have human rights or 
democracy as official preconditions for membership, but the opinions of European diplomats were still sought by the journalists. The commissioner for industrial policy, Spinelli, was concerned about the situation. He pointed out that Turkish democracy was under risk and that the Community could not remain silent if the fundamental rights were threatened. The "deputy foreign minister" of the organization, Terfloth, was less worried. He noted that formation of a new government showed that Turkey still had a functioning democracy: "For the Common Market, at present democracy exists in Turkey. There is no problem as long as fundamental rights are not abused and a military dictatorship that destroys these rights is not in power" ${ }^{52}$ (as cited in Birand, 1971, p. 9).

Nevertheless, 1971 ultimatum rapidly changed the perception of Turkish Republic within the human rights community, something that the 1960 coup d'etat failed to do (New York Times, 1972). It is noteworthy that in 1968, Sean MacBride, then the Secretary-General of International Commission of Jurists (ICJ), ${ }^{53}$ counted Turkey along with other members of the Council of Europe as a country where "rule of law operates reasonably well" (MacBride, 1968, p. 157). This positive view of Turkish democracy was being eroded. The practices of ill treatment drew the attention of Amnesty International (AI) who adopted a "prisoner of conscience" from Turkey in 1972 (Morris, 1972, p. 33), the political situation in Turkey was discussed in the Council of Europe in 1973. ICJ published a report on human rights in Turkey in its 1973 Review (International Commission of Jurists, 1973). This report was also notable for its implicit emphasis on the primacy of legal actors in line with the constitutional strategy of human rights. While

\footnotetext{
${ }^{52}$ It seems that Birand was talking about Dr. Klaus Terfloth, a West German diplomat. Terfloth was the chef du cabinet of the EEC commissioner for external relations at the time (Hawtin, 1971).

${ }^{53}$ The ICJ was established in 1952 to promote rule of law, human rights law and institutions nationally and internationally. MacBride became its Secretary-General in 1963 (Tolley, 1989).
} 
accounting the shift towards repressive legislation in Turkey, the only resistance and hope highlighted by the report was the statements of constitutional lawyers who criticized the resolutions of the Constitutional Court and a courageous military prosecutor who opposed proclamation of martial law.

Activists adopted an accusatory strategy, providing a grimmer picture of state practices. A group of political activists self-exiled to Europe following the 1971 ultimatum (Aydemir, 2008) presented an account of human rights in Turkey in their publication (Democratic Resistance of Turkey, 1972). Unlike the rather soft attitude of the Turkish Bar Association and some intellectuals mentioned above, the booklet represented Turkey as a peripheral European country that was turned into "a huge concentration camp" (p. 6) where military had become the real ruler despite the dissimulation based on a functioning parliament. The military had concentrated all judiciary, executive and legislative powers in its hands and adopted torture of prisoners as a policy. The fascist nature of the military regime was demonstrated by its repression of human rights, democratic demands as well as by its collaboration with the international and national bourgeoisie.

This political discourse on torture in Turkey was echoed in a book published by Jane Cousins (1973). The author was a political researcher between 1971-1973 for Harold Wilson, then the leader of the British Labor Party in opposition (Ashford, 1973). Cousin's study made explicit political points about both UK and Turkish politics. It harshly criticized British conservatives for shielding Ankara from criticism and called the Justice Party of Demirel "corrupt right wing." The book manifested many parallels with the File on Turkey and mentioned the latter as one of the sources of information. Cousin's 
research and visit to Turkey left her with several clear conclusions: "democracy no longer exists in Turkey, military regime operates behind a façade of democracy, regime uses past as a source of fear, use of torture is a systematic policy" (Cousins, p. 1). The book reiterated the notion that Turkey was under the control of the armed forces, which had "become an economic force of its own" by virtue of the corporations it established (Cousins, p. iv). Similar to the points by Democratic Resistance of Turkey, Cousins restated the capitalist character of the armed forces. ${ }^{54}$

Both the File on Turkey and Turkey: Torture and Political Persecution relied on shaming tactics through the exposition of facts of political violence and attribution of alternative meanings to the policies of Ankara's allies. This method was gaining foothold in human rights movement in those years. The rhetorical commitment of Turkish state to human rights and democracy made it more useful for accusations and shaming tactics. An integral part of this strategy was the collection of reliable information on the basis of which challenges to the state could be launched and the attention of the media could be attracted. In addition to contributing to the spread of what I called the new empirics of torture, the reports used techniques such as on-site visits, testimonies, news reports and documents to create an account of political repression in the country. Medical reports of victims were also deployed as scientific proofs against the statements of those in power. The state, on the other hand was growing impatient with such reports of torture and ill treatment. What amounts to an official reaction to allegations of torture can be found in a

\footnotetext{
${ }^{54}$ It is also interesting to note that Cousins seemed to lament the opening of "economic and social gap between people and army" that contributed to the suppression of the people. In this way, Cousins recycled a view held by some sections of the Turkish left in the late 1960s and 1970s that armed forces was a "progressive force" in the country. In this revolutionary strategy, low and middle-ranking soldiers would help overthrow of the "feudal and comprador interests" (Zürcher, 2004, p. 255). Yet as the army engaged in business, its ranks became less interested in the destiny of the people.
} 
propaganda-style book called the "White Book: Turkey's Realities and Terrorism" (Beyaz Kitap: Türkiye'nin Gerçekleri ve Terörizm) ${ }^{55}$ The book sought to discredit the radical opposition not only by claiming that allegations of torture were pure fabrications of the subversives but also by asserting that the subversives were guilty of several high profile acts of sabotage. The publication of the book itself was an indication that the state was concerned about the claims and sought to respond to the accusatory strategy of the human rights advocates.

The accusatory strategy exemplified by these two publications had a double target. On the one hand they addressed the conscience of an imagined western public, who would pressure their own governments to take initiative to stop repression in foreign nations, or at least retract diplomatic support. It was thought that repressive states, which were unpopular at home, would be vulnerable to pressures from abroad. Second, these reports targeted the relations between bodies such as Council of Europe, EEC and NATO and the Turkish political leadership who saw association with them as a source of political stability and security. The accusatory strategy attempted to get the network put pressure on Ankara whose practices were not appropriate to the human rights and democracy commitments of this political alliance. In a sense, the practices of the accusatory strategy network was similar to the so-called boomerang model outlined by Keck and Sikkink (1998, pp. 12-13). ${ }^{56}$ Yet this strategy had a paradoxical character: In the reports mentioned above, Turkey was described as a country enmeshed in a web of

\footnotetext{
${ }^{55}$ The book was prepared by an "inter-ministerial council" under the orders of the Office of the Prime Minister (Turkiye Cumhuriyeti Basbakanlik, 1973).

${ }^{56}$ According to the boomerang model, domestic human rights groups faced with an unresponsive or repressive state seek international allies. These allies, such as international organizations or other states, in turn put pressure on the state in question to comply with human rights norms. In the Turkish case of early 1970s, the function of domestic human rights actors was assumed by political exiles.
} 
capitalist interests, which it could preserve against demands of social justice only by resorting to political violence and torture. This was the nature of the regime itself. The analysis of human rights in Turkey was built upon Marxist notions of international capitalism and fascism, and the state practices of torture were conceptualized within such a discursive universe of working class vs. bourgeoisie and contradictions of capitalism. The remedies suggested by these publications, however, were not consistent with this description of the world order understood as a capitalist system. On the one hand, the accounts asked Western capitalist nations to exert pressure on Turkey for political liberalization and on the other hand, torture and political persecution was explained with reference to the same international capitalist network of relations. Indeed, proposals of the activists did not go beyond an international enquiry (see Cousins, p. 60). The Marxist lexicon of the activists also implies that the Cold War geopolitics was relevant to the accusatory strategy. As well known, by emphasizing democracy and civil liberties Western states presented themselves as the anti-thesis of the Soviet bloc in the Cold War. By bringing forth the human rights violations in Turkey, a member of the Western camp, the activists of the accusatory strategy were simultaneously launching an attack on the association of the North Atlantic area with human freedom and dignity. The exposure of the links between Western states such as UK and Turkey became meaningful in such a framework.

The reliance of the activists on Western nations also reflects their assumption that a liberal political regime cannot co-exist with practices of torture. As Kelly argues, although this assumption is not verified by historical record, it forms an essential component of the discourses and practices of the human rights community as well as 
Western diplomats (Kelly, 2009). In his study on the UN Committee on Torture, Kelly points out that this assumption of association between liberal and Western institutions and lack of torture reflects the conviction of human rights community in a version of "liberal peace theory" where "states with liberal institutional structures are more likely to comply with the Convention, and that liberal institutions produce liberal practices all the way down" (Kelly, p. 798)

To summarize, in the early 1970 s, we see the emergence of a network of activists and intellectuals who were concerned about (or victims of) torture in Turkey and cooperated by sharing their resources such as newspaper reports, affidavits, and photographs. These actors adopted an accusatory strategy towards the Turkish state and sought to influence it through shaming. More significantly, as seen from the lack of action by the $\mathrm{CoE}$ and EEC or major Western states, the network failed to enroll political authorities in their struggles against abuses of human rights. Certainly, torture was problematized as a practice but this problematization has to establish alliances with other authorities in order to be effective. As Foucault put it "there are actually a whole order of levels of different types of events differing in amplitude, chronological breadth and capacity to produce effects" (Foucault, 2000, p. 116). The problematization of torture in the 1970s stayed at a lower amplitude as it could not enroll neither the Turkish state actors nor the international community to bring about shifts in policy. ${ }^{57}$

The below Figure 3.1 (p. 173) nicely reflects the accusatory strategy of the 1970s and 1980s. This is a Turkey campaign poster prepared by the Amnesty International in

\footnotetext{
${ }^{57}$ One can point out some preliminary ideas as to why an association between activists and international political authorities did not obtain. The Marxist jargon of the reports, lack of sufficient contact between activists and Western political leadership, the focus on Latin American countries where the dictatorial nature of the regimes are more clear may be cited as some reasons for this situation.
} 
1980 , which has never been used as such due to the September 12 coup in the country (Flickr, 2011). It depicts a police officer with aviator glasses. When the reflection on the glasses are examined one sees as windsurfing tourist. This is a clear reference to the Western public who came to see Turkey as a holiday destination. The message to the Western public is that Turkey is not only about "sea, sun and sand." There is also the "Real Face" of Turkey as AI puts it, which is about torture, capital punishment and persecution. As such, the poster is a nice example of not only the naming and shaming tactics of the accusatory strategy but also its reference to the links between the West and states which abuse human rights.

\section{3 "September 12" Period}

Harsh security measures and political persecution suppressed the dissent and political violence only for a few years. In the late 1970s, political activism on both right and left began to rise again. Especially after 1977, the general atmosphere began to worsen with massacres and attempts of the right and left-wing groups to gain control at the street level by force. For a time, political killings amounted to ten people a day. This prepared the ground for a third military intervention by the armed forces on September 12,1980 . The general population, resigned at the level of political violence, "welcomed" the takeover by the generals. Yet, this time the rule of the Generals would overwhelm the political and social structure of the Turkish society with effects that are still relevant. Unlike the 1971 intervention, military control of the society was firmer, and the army was not eager to initiate a quick return to the civilian administration. The military rule lasted for three years until the parliamentary elections in November 1983 but the influence of the armed forces continued. We can mention two mechanisms for the continuation of the 
tutelage of the armed forces on Turkish politics. One was the new constitution, which entrenched the position of the armed forces within the polity by increasing the authority of the military dominated National Security Council in the policy-making process. The second was the approval of Chief of General Staff Evren as the President. Although he had retired from his military duties in 1983 Evren went pushing the policy of the military in Turkish politics. The new constitution prepared under the watchful eye of the army concentrated powers in the President. This office would have extensive powers including the dissolution of the parliament, appointment of the Prime Minister, supervision of public bodies, veto legislation or submit legal amendments to the Constitutional Court (Tachau \& Heper, 1983, p. 29).

The post-September 12 period has been characterized by practices that led to an unparalleled level of human rights violations in the country. Unofficial figures suggest that more than 600,000 people have been detained between 1980 and 1983 (Anar, 2000, p. 140). An oft-quoted figure for the number of people arrested for political activities and terrorism is 60,000 (Dagi, 1996, p. 125). ${ }^{58}$ Following the coup, the maximum period of detention without trial was extended to 90 days by a decree issued by the National Security Council in November 1980 (Milliyet, 1980b).

${ }^{58}$ The Turkish population stood at around 45 million in 1980, around $44 \%$ living in urban areas. 


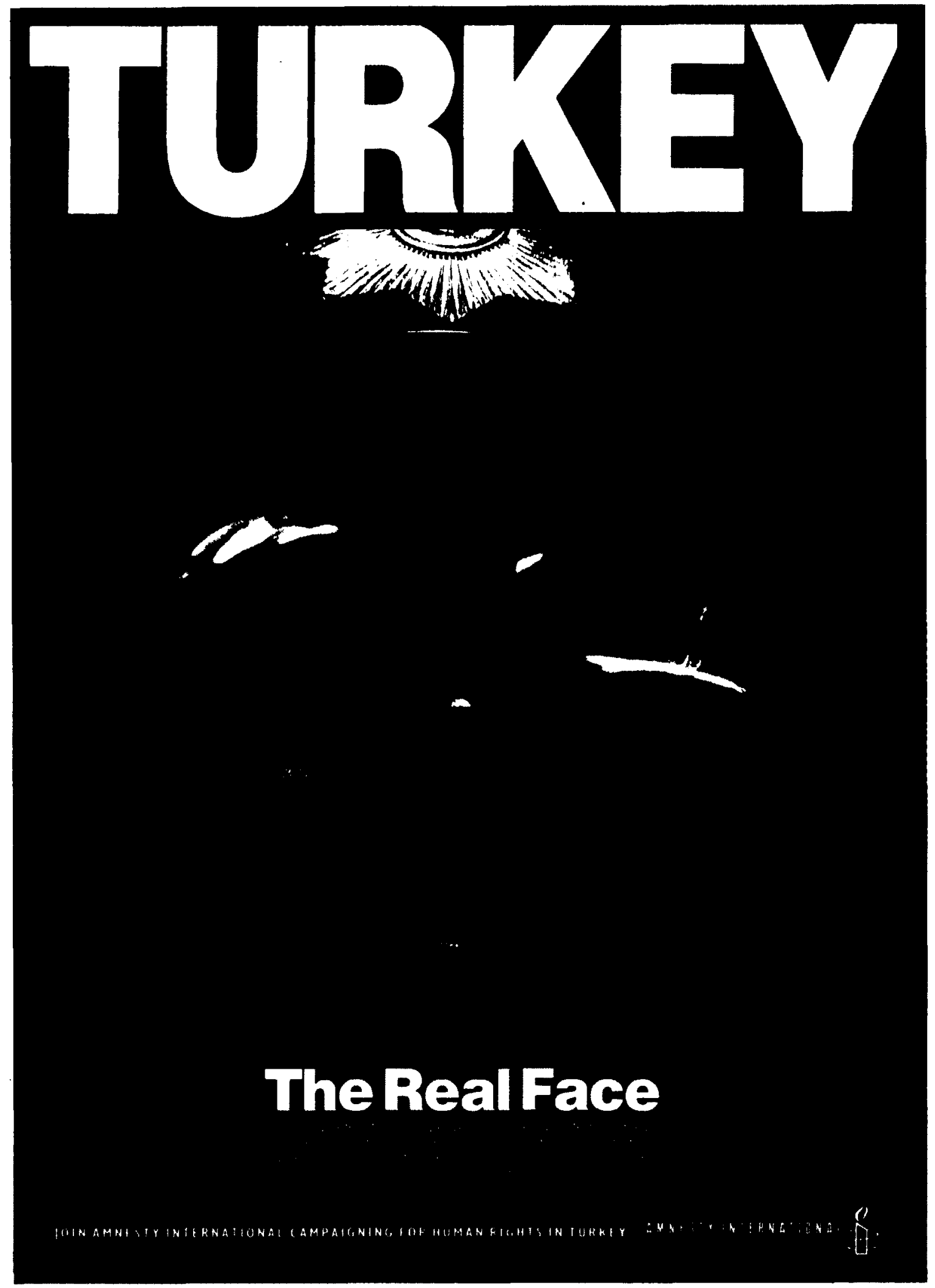

Figure 3.1 A poster prepared by Amnesty International. (C Amnesty International. 
Initial reaction from the West was muted. Cold War concerns were placated by the armed forces by a pledge of allegiance to the NATO framework in the early days of military intervention. Strained relations between East and West following the Afghanistan invasion of Soviet Union and the Iranian Revolution of 1979 required that Turkey be kept within the fold of the Western camp. Major European nations also seemed to "understand" the security concerns of the generals but still urged them to return to civilian politics as soon as feasible. Western capitals and international organizations emphasized "normalization" while expressing criticism of instances such as the ban on civil and political organizations, detention of politicians and trade union activists and torture.

In this process, both the European Parliament and the Council of Europe took a critical stance towards the military regime. On September 15, an EP official demanded the immediate release of prisoners and return to civilian regime and noted that this was a precondition for full application of the existing agreements between EU and Turkey (Ugur, 2004, p. 270). In a text adopted several weeks after the coup, Parliamentary Assembly recommended the Council of Ministers of the $\mathrm{CoE}$ to "follow the developments very carefully" (Parliamentary Assembly of the Council of Europe, 1980, $\S 11$ a) besides reminding the sanction of suspending Ankara from the organization. The stance of the European nations, on the other hand, started to change as reports of ill treatment increased.

\subsection{Problematization of Allegations of Torture: 1980-1995}

The 1980 coup is usually regarded as the watershed in terms of the internationalization of human rights questions of Turkey (see Dagi, 2000). In this period 
many foreign observers, organizations and states scrutinized the human rights record of the country. The Council of Europe, the European Parliament, international NGOs, European countries and the United States often inquired about detainee rights and pressed on Ankara for improvements. If we look beyond this human rights diplomacy, what was contested were the definitions of human rights and torture itself. In the post-1980 period, governments, NGOs, activists and international institutions challenged each other on the veracity of human rights situation in the country, what constituted torture, how can one state that there exists torture, who is authorized to pronounce this, how torture is characterized and how can a state eradicate torture. This section mainly focuses on the attitude adopted by the ruling elite in this period, and discusses other actors in relation to this. It tries to show that the state adopted a three-pronged "policy" of neutralization of the allegations of torture. The three aspects which will be dealt in greater detail below are (1) limited acknowledgement of cases of torture and engagement with human rights NGOs like the Amnesty International, (2) prioritization of state-sanctioned channels for the investigation of torture cases and (3) a concern to manage the flow of information regarding the human rights situation in the country in general and torture in particular. This three-pronged neutralization policy was a response to the accusatory strategy. This is evident in the way it gave weight to international publics which constituted a significant support base for this strategy.

\subsubsection{Definition of the Official Policy}

One of the conclusions of human rights literature is that improvement of rights performance is a gradual process that starts with denial. Denial of abuses and counterclaims soon evolve into acknowledgement of issues, with the help of international 
community (Cohen, 1996). This is also one of the points made by constructivists who employ the "spiral model" to conceptualize progress in human rights (Risse \& Sikkink, 1999, p. 17). This model incorporated the earlier studies on the boomerang model and argued that there are five phases of human rights reform. In the first phase, state violates human rights of its citizens but the civil society actors are weak and do not have transnational links. As domestic groups organize and contact with transnational actors, the state comes under the pressure of what I called the accusatory strategy of human rights activists. In this phase states deny the existence of violations, validity of human rights norms or the legitimacy of transnational interventions. Owing to the pressure from human rights networks, the denial phase is superseded by a phase of tactical concessions and adherence to the rule of legitimate statehood in the last phase of the model. Focusing only on the phase of denial, we can say that the model fails to account for not only the theoretical commitment of the military regime to human rights but also for the fact that the main mode of dealing with the accusatory strategy cannot be satisfactorily defined as denial. Although Risse and Sikkink are mostly interested in East European examples in their study, the denial thesis is suggested by Rod Morgan who included Turkey in the group of countries where there was "general denial, but concessions by politicians that [torture] may occasionally happen" (Morgan, 2000b, p. 183). A closer study of the official posture in this period shows that denial certainly exists; yet this notion does not sufficiently characterize the state practices regarding allegations of human rights abuses. In this section, I argue that official policy until the mid- 1990s cannot be defined as "denial" but rather as a "combat against allegations of torture." That is to say, the government's efforts to manage and control were directed more at the object of 
allegations and less at the practices of torture itself. To put it in Hunt and Wickham's (1994) vocabulary, what the governments most sought to manage (their known object) was the allegations of torture rather than the practices of torture.

To begin with, the military regime and the governments that came to power after the transition to civilian rule have been sensitive to the accusatory strategy. Indeed, this concern was apparent in the 1970s when the Office of the Prime Minister prepared the aforementioned White Book. As pointed out in the introduction, from the late $19^{\text {th }}$ century on state was constituted as a potential part of the European and Western world and this discourse was entrenched in the aftermath of the Cold War, with Ankara's rapprochement with the United States. The intention to become part of the EU was also influential in keeping engagement of Ankara with Western capitals going (Dagi, 2001). This discourse coded human rights as part of the identity of the Turkish state and one of the bases of its relationship with the Western world.$^{59}$ This language of politics tended to admit cases of torture albeit by contextualizing them either as personal or non-intentional. There were cases when the prevalence of ill treatment was "confessed" by several high ranking figures including the left-leaning Prime Minister Ecevit prior to the 1980 coup (Günver, 1989, p. 148). In the post-1980 era, "official attitude" regarding allegations of torture was determined by the Chief of General Staff:

Torture is an inhuman action that can in no way be adopted as an official method by the Military Administration... Torture and ill treatment had existed in the pre-

\footnotetext{
${ }^{59}$ It is notable that while some Asian countries such as Malaysia and Singapore resorted to cultural inclinations towards authoritarianism (the so-called "Asian values") to justify disregard for civil and political rights, no such trope exists in Turkish political discourse. On the contrary, state actors often strived to find parallels between human rights principles and humanitarian ideas of Anatolian thinkers such as Rumi. For an example see Senol's remarks (Senol, 2002, pp. 315-316) who was an advisor at the Office of the Prime Minister.
} 
12 September period but the proceedings against those who are involved in [torture] are being announced without denial for first time by this administration. (As cited in Bölügiray, 1991, p. 137)

Military administration and civilians after them have conformed to this policy of limited acknowledgement. They engaged with the international organizations and human rights NGOs, and released information regarding allegations and proceedings against suspected torturers. However, it is difficult to discern a consistent and systematic effort by the military to prevent torture or take effective precautions against it. Ill treatment of detainees was tolerated and often ignored but simultaneously the junta sought to demonstrate that it did not approve these aberrations. The military was more concerned about combating allegations of torture rather than practice of torture itself. When authorities talked about torture, they usually emphasized that their efforts were meant to prevent allegations, rather than the practice itself. This attitude was not only a euphemism to avoid admission of torture but showed that they were concerned about the effects of allegations more than the practice of torture itself.

As indicated, the first aspect of the official approach was limited acknowledgment of abuses and engagement with international actors that were concerned with this issue. The second aspect of this attitude was the delineation of an official definition of torture in state practices and the proper ways of announcing this sort of an incident. The lack of a stabilized and legal definition of torture that incorporated its physical and psychological aspects made it easier for the officials to control the regime of truth on torture. As will be recalled from the previous chapter, until 1984 an international legal definition of torture was not available. The $1975 \mathrm{UN}$ declaration had defined what constituted torture, but it 
did not have the power of law. What constituted torture and how it differed from degrading and inhuman treatment had been subject to some debate at the ECtHR as well. Moreover, Turkish Penal Code of 1926 did not provide a definition of torture while prohibiting it. Thus, to a significant extent, torture was defined and redefined in the legal and political discourse rendering it a dynamic/discursive "known object." State officials in charge of security tended to set the threshold high and conceive torture as extreme physical abuse, typically including brutality. This conception is apparent in the memoirs of a Turkish lieutenant general Nevzat Bölügiray, who was in charge of the coordination of the martial rule between December 1980 and September 1983 (Bölügiray, 1991). The commander was relatively more sensitive to human rights issues and undertook some initiatives to "prevent abuses" with the approval of top brass. Yet in his memoirs he admitted that his conception of torture was limited to "bodily torture" (Bölügiray, p. 131) ${ }^{60}$ This definition of torture as physical abuse was not fixed with legislation. Nevertheless, it formed the basis of state conduct. This conception was put into practice by giving priority to allegations of physical torture by emphasizing medical and autopsy reports as evidence in court proceedings.

Apart from the exclusive and narrow definition of torture, official attitude on torture asserted that a certain incident could be deemed as such only by the organs of the state, in particular the judiciary. Bölügiray established a mechanism to deal with complaints of torture in June 1981 with an order sent to the regional martial law commands. He ordered the regional commands to forward complaints directly to the regional military courts. Allegations received by the Chief of General Staff (e.g. from

\footnotetext{
${ }^{60}$ Note that the 1974 Bar Association report quoted above also seems to limit torture to physical abuse.
} 
human rights organizations or relatives of victims) would also be directed to the relevant military commands which in turn would send them to the courts and then follow up the process. This procedure aimed to responsibilize the commanders and prevent cover-ups by shifting the authority of decision to the courts. Thus, the commanders would not be able to dismiss allegations of torture as implausible. The general also ordered that for people who are sent to prison or released from detention, an official medical report should be prepared and their photographs taken. In cases of death in detention, an autopsy report should be prepared (Bölügiray, 1991, p. 135). Bölügiray had prepared an informal recording system he called "torture book" (işkence defteri) where he noted the cases that he was dealing with and used it to follow up the cases in coordination meetings with other commanders. Military rule was responsive towards allegations of torture but insisted that courts were the only authorities to pronounce decisions on the issue. The judiciary, in turn, relied on official medical and autopsy reports excluding testimonies from the victims. It also often acquitted torture suspects on the grounds of lack of evidence, failure to determine the culprits or by merely dismissing allegations as unreasonable (Tusalp, 1986, p. 121ff).

Although well intentioned, Bölügiray's scheme had allowed many cases to fall between the cracks. The precautions were bound to fail in a process where suspects were detained incommunicado for up 45 days within which time bodily marks of torture could disappear or become illegible. ${ }^{61}$ Although he called the orders "preventive measures," they were indeed very much reactive and dependent on his personal initiatives. The supervision of the detention centers were left to the regional commands, which were on

\footnotetext{
${ }^{61}$ In September 1981, maximum period of detention was lowered from 90 days to 45 days. In May 1985 this was again brought down to 30 days (Oberdiek, 2007).
} 
many occasions tolerant to ill treatment. In addition to this, his tactics were based on punishment and hence sought to deter the wrongdoers rather than monitoring the situation and preventing abuse. Perhaps more importantly, the existence of such an ineffective mechanism to deal with allegations of torture helped the military regime to put a distance between itself and incidences of torture. The largely ineffective measures taken by the military and the engagement with the NGOs were shown as proofs that the military did not have a policy of torturing suspects. This neutralization policy was not peculiar to the military administration, though. It was sustained and expanded in new ways under the civilian governments even when positive steps were being taken to tackle the problem.

\subsubsection{Transition to Civilian Rule and Combat against Allegations}

Amid growing external and internal restlessness for transition to civilian rule, in January 1982 the generals declared a timetable for transferring power. A new draft constitution was announced to the public. However, this did not mean a quick return to pre-1980 political activity: former political leaders were still banned from political activity. In the referendum in October 1982, more than $91 \%$ of the voters approved the new constitution and General Evren's presidency ${ }^{62}$ (Tursan, 2004). In the elections that took place in October 1983, the winner (close to $45 \%$ of the votes) was Turgut Özal's party ANAP (Motherland Party) that professed a broadly liberal center-right platform. ${ }^{63}$

Despite the "transition," there was limited change in the official regime of truth on torture. The policy of engagement with international institutions and human rights

\footnotetext{
${ }^{62}$ Evren assumed presidency in November 1982 and remained the Chief of General Staff until July 1983 (Genelkurmay Baskanligi, n.d.)

${ }^{63}$ Özal was no newcomer to the politics. He had stood (and failed) for an Islamist party back in 1977 and was a former World Bank employee. He was undersecretary to the Prime Minister before the 1980 coup and Evren had appointed him as the minister responsible for economic affairs following the take over (Ahmad, 2003).
} 
organizations was continued and their allegations were taken into consideration. Amnesty International and other human rights analysts were pursuing the accusatory strategy by insisting that torture was a systematic practice in the country (Amnesty International, 1988). The civilian government insisted that torture was not an official policy while maintaining that judicial authority was competent to decide on allegations of torture. Newspapers reported cases of conviction of officers due to torture and suspects were allowed to contact their relatives or lawyers subject to certain conditions (see for instance Milliyet, 1987). There were even ad-hoc fact-finding visits by Turkish MPs to prisons who reportedly failed to come across any incidences of torture (Milliyet, 1984). While the offenders were punished on some occasions, the government did not take credible steps to reduce impunity. Legislation proposed to increase the penalty for torture and to ensure that all detainees can contact their relatives and lawyers was blocked by the ruling party.

In the late 1980s, Premier Özal began to entertain the idea of application for full membership in the EEC. His program for export-oriented growth required access to a market such as Europe in order to be viable in the long run. It was thought that the bureaucratic problems that many Turkish exporters faced in accessing this market could be solved by deepening the relations with the European bloc. Yet rapprochement with the European Community required political reforms as well. Despite transition to civilian rule, Turkey was not yet considered a credible democracy. ANAP had won the premiership in an election where many competitors were vetoed by the National Security Council. Besides this appearance of "controlled democracy," there were many problems in the field of freedom of expression and security of the person. Ankara's declaration of 
acceptance of individual right of petition to the European Commission of Human Rights in February 1987 needs to be considered in this context. This was a largely diplomatic move to improve Turkey's image. Half-heartedness of Ankara can be derived from the fact that it attached a letter of interpretation to its declaration, valid for three years, which said that "the notion of democratic society" (as cited in Cameron, 1988, p. 889) in the Convention must be interpreted in conformity with the Turkish constitution.

Another significant move came in 1992, with the amendment of Turkish criminal procedure. The coalition in power, wrought with disagreements within the cabinet and with Özal who moved to the post of presidency and held the power of vetoing proposed legislation, was able to introduce some human rights reforms, including safeguards against torture. The primary aim of the reformers was amending the Code of Criminal Procedure of April 20, $1929 .{ }^{64}$ Amendments to the Code stipulated the principles regulating the process of statement taking and interrogation of suspects and the accused by the law enforcement personnel, public prosecutors and judges (Adalet Bakanligi, n.d.a). It introduced measures similar to the ones known as "Miranda" in the United States, such as informing the suspect of the accusations, the right to a defense lawyer and the right to silence. Most prominent among the changes was that lawyers could accompany the detainees in the interrogation process and that ill treatment including torture, delivery of drugs, exhaustion, deception, bodily coercion and violence, physical and psychological interventions that would affect the will of the suspect were expressly forbidden. In cases where these methods were deployed, statements could not be admitted as evidence in

\footnotetext{
${ }^{64}$ The code was a translation of the German Code of Criminal Procedure of 1877 . It was adopted by the Republican regime with some changes (Golzuklu, 1962).
} 
courts. In addition to these, maximum period of detention was reduced to 8 days. ${ }^{65}$ These measures, heralded as reforms that would make torture "out of question," were qualified in two ways. First, geographically, in provinces where the state of emergency was in force (most of the southeastern part of the country due to military operations against armed Kurdish militants) the principles regarding the right to lawyer and detention periods would not apply. The second qualification was effected through the distinction between types of crime. If the suspects were held on terror related charges, or charges that were under the jurisdiction of State Security Courts, they would not be able to take advantage of these measures.

The amendments to the code were adopted at a time when Ankara was trying to improve its image in Europe. This was motivated by a rapprochement between Europe and Turkey in the aftermath of the collapse of Eastern Bloc. There were diplomatic signals that a Customs Union between Turkey and EEC could be possible and that Ankara had to accelerate the process to avoid sidelining by the East and Central European countries (Birand, 2005). Indeed, Premier Demirel had indicated that he had promised these reforms to the EEC (Mater, 1992). In addition to this, the reforms did not address the problem of police impunity or prevention of torture. At best, they provided guidelines for interrogations and statement taking and reduced the risk of ill treatment by decreasing the maximum period of detention. However, perhaps the most vulnerable segment of the suspect population, people held on security related charges, were exempt from these reforms.

\footnotetext{
${ }^{65}$ The regular detention period was determined as 24 hours. In "collective crimes," this could be extended to 4 days on the request of the prosecutor, and this could again be extended to 8 days with the decision of the judge in cases where preliminary inquiry required.
} 
Despite the reform and safeguards against torture, the policy of neutralization was going on. In addition to the practices of (1) limited acknowledgement and engagement with human rights NGOs and (2) prioritization of official definitions and methods of investigation of torture that were mentioned above, the state also attempted to make sure that (3) it managed the information regarding torture in Turkey. Allegations still prompted adverse reactions by officials. An MP was prosecuted for "harming the external prestige and influence of the state" due to speech he has given abroad about human rights situation in Turkey (Milliyet, 1986, p. 13). It appeared that the state especially wanted to manage the flow of information towards international audiences, as if their opinions had a higher value of truthfulness in determining what the human rights situation in Turkey was. In line with this, a conference in 1991 where human rights problems would be addressed by President Özal was open only to MPs and European experts, while local human rights organizations were excluded from the meeting (Lyon, 1991).

This anxiety about international expertise and opinions on the exercise of rights in Turkey was not limited to few judicial actions or conference invitations. It was also institutionalized in certain official bodies. Again, at a time when Customs Union with the EEC became a hot topic in Turkey, an important resolution was taken at the National Security Council. This council was established with the 1961 Constitution and brought together certain members of cabinet and the high command of the armed forces. This organ gradually extended its mandate and influence in the government becoming a symbol of the meddling of the military in politics (Parla, n.d.). In a resolution taken by this Council in 1994, it was decided to form a "Consultative Council on Human Rights" (Insan Hakları Danışma Kurulu) which would be attached to the Office of Prime 
Minister and be comprised of officials from the Chief of General Staff, Ministries of Foreign Affairs, Interior and Justice, National Intelligence Organization (MIT) among others. This council of security professionals was designed as a center of knowledge production to improve Turkey's image both abroad and domestically. It is worth quoting the circular establishing the working methods of the council at length:

Mutual and intensive contact activities will be programmed between influential persons and institutions and such persons, institutions and organizations abroad. Enlightenment activities will be carried out, both inside and outside the country, by organizing various seminars, conferences, congresses, symposiums, and meetings towards appropriate targets through working on appropriate themes. In regions where incidents have taken place, the consciousness of the domestic and foreign media will be raised by ensuring rapid, correct and visual information flow between press centers in Turkey and influential media institutions in Europe and USA. (As cited in Milliyet, 1994b, p. 14)

The circular, which was leaked to the press, clearly shows that one of the primary concerns of the state was the management of the information regarding torture, rather than solving the problem itself. It seems that the state actors were especially concerned about the information that reached to the foreign press organizations. This practice needs to be thought within the context of the unsatisfactory freedom of press in the country, which made it easier for the state to manage information regarding human rights abuses. As Catalbas (2007) notes, in the 1990s, journalists in Turkey operated under overt and covert political pressures from the state institutions especially when it came to politically charged topics like the conflict in the southeast or the Islamic identity. To a certain 
extent, the issue of torture can be included in this no-go zone of journalism. This aspect of the policy of neutralization indicates that the state was concerned about the reception of news about human rights abuses by foreign as well as the domestic publics. This should be read as response to the utilization of press and Western public pressure by the activists of the accusatory strategy.

As can be seen from the account above, until the mid-1990s a network comprising different state actors- was successfully maintained. Political decision makers along with security officials saw human rights as an obstacle in the fight against terror and postponed enjoyment of rights after the suppression of armed conflict. Security personnel were also enrolled in this network with its use of illegal and extralegal methods such as ill treatment and disappearances. However, as a country with reasonably independent legal system, the cooperation of political and security wings were not sufficient. Many members of the legal profession (i.e. state prosecutors and judges) were also cooperating with the official strategy by ignoring or tolerating these incidences. In cases where this was not possible, e.g. when a case was brought to the court alleging torture, reduction or postponement of sentence or acquittal of the suspects on the basis of lack of evidence were options available to the legal profession. The lack of evidence for prosecution, on the other hand, pointed to the participation of police officers and medical experts in this network. "Solidarity" of police officers against allegations was complemented with the actions of medical experts who were supposed to document ill treatment of detainees. While the judicial decision making often did not take into consideration certificates from non-official medical authorities, some medical experts helped bring about unaccountability by issuing almost identical reports that "no trace of 
abuse has been found in the victim." ${ }^{.66}$ This association of actors was not always

effective, though. The cases of ill treatment and impunity co-existed with cases where security officials were punished or medical experts reported bodily marks of torture. In the mid-1990s, several trends coalesced to transform this regime of truth in Turkey and challenge the network. Amidst the lessening of the conflict in the southeast, broader transformations of the attitudes towards torture, and the mounting requirements of the European Union membership process, the official thinking with regard to torture seemed to embrace aspects of the preventive strategy outlined in Chapter 2. In the next section, we turn to these developments.

\subsection{Reproblematizing Torture: $1995-2005$}

In the mid-1990s, the armed conflict in the southeastern part of the country tended to deescalate after many years of bloodshed. Throughout the 1980 s, PKK, an armed Kurdish group, had engaged in acts of violence against Turkish and Kurdish population in the southeast and in larger urban centers (Gunter, 1997). According to official calculations, between 1984 and 2009, more than 41,000 people died in this conflict (Sener, 2010). In the early 1990s, the intensity of this conflict tended to decrease due to several reasons ${ }^{67}$ The Association for Human Rights ${ }^{68}$ recorded 1412 instances and

\footnotetext{
${ }^{66}$ Indeed a parliamentary inquiry found in 2003 that some government doctors in Izmir had prepared a very practical seal that said "no trace of torture or battery has been found" and used it to fill out medical reports (TBMM Insan Haklarini Inceleme Komisyonu, 2003, p. 1).

${ }^{67}$ The armed forces changed their tactics against the PKK and aimed to assert their control over the territory. Coupled with the deployment of new arms technology and adoption of counter-insurgency tactics, this move weakened the position of the PKK. In this context, the only way out for PKK leadership seemed to be extending the area of engagement with the security forces by shifting its militants towards the urban areas (Ozdag \& Aydinli, 2003). This led to a decline in the intensity of conflict as the number of engagements between security forces and the PKK militants decreased.

${ }^{68}$ This association should not be confused with the Human Rights Association of the 1940s.
} 
allegations of ill treatment in 1995 while this figure dropped to 346 in 1996 (Insan Haklari Dernegi, n.d.-a, n.d.-b).

In addition to the decrease in the armed conflict, in the mid-1990s several cause célèbres put the issue of torture at the top of the political agenda. One of these was the beating to death of the journalist Metin Göktepe in police custody in Istanbul (see Amnesty International, 1995) and the second was the case concerned with a group of students popularly known as Children of Manisa (Manisall Çocuklar) named after a city in western Turkey (Turkish Daily News, 1996). The mainstream media followed these two cases closely and reported the developments in the judicial process. With the start of the Customs Union between the EU and Turkey seen as the first decisive step on the way to becoming European, many opinion leaders projected these two cases as habits that Turkey has to leave behind in order to attain its rightful place in Europe. The media reports also helped to construct a concerned public which arguably indicated the turning of the tide in Turkey.

In addition to this new phase in the conflict between the PKK and the security forces and the growing dissatisfaction with Turkey's human rights record, there were also signs of change in the approach of the political elite towards torture. From late 1980s on, official discourse increasingly pointed to underdevelopment and lack of resources to explain incidences of torture in the country. Semih Günver, an experienced diplomat who represented Turkey at the Council of Europe in the post-1980 period wrote that "I have always believed that torture exists in Turkey as a practice that is habitual and uncontrollable rather than as a state policy" (Günver, 1989, p. 148). Turkish officials often underlined that torture was banned by the legislation including the Constitution. 
Yet, the conditions prevailing in the country, especially the insufficiency of education was reflected in the quality of public administration in a very negative way. After all, the police department was composed of Turkish citizens that constituted a microcosm of the society. A Foreign Ministry official put the issue thus: "Many of our people, including police, are from peasant stock and in some places beating has been a way of life, but we are trying to overcome this" (as cited in Owen-Davies, 1989). When the officials talked about insufficiency of education, what they meant was not necessarily the lack of formal schooling. According to records of the Ministry of Interior, in 1992, roughly $90 \%$ of the police officers had at least 8 years of formal schooling (Gureli, 1992). The concern was rather the philistinism of the police officers, or the failure of the formal education to transmit liberal values to the cadets. The underdevelopment of the country was also reflected, in this account, in the training of the Turkish police. The first civilian prime minister in the post-coup era, Turgut Özal, explained the situation thus:

I am not saying there is no torture in our prisons. It could not be so because the security people are not educated to deal with what is a new type of prisoner for them, the ideological terrorist prisoner. These prisoners are much tougher, they do not normally think of themselves as killers or thieves. They think they have ideals. (As cited in Tonge, 1984, p. 3)

The US Undersecretary of State Elliot Abrams ${ }^{69}$ corroborated the prime minister: "Police forces are decentralized, very poorly trained and lacking in discipline. We would

\footnotetext{
${ }^{69}$ Elliot Abrams was Assistant Secretary of State for Human Rights and Humanitarian Affairs between 1981 and 1985, under the Reagan administration. He later assumed duties for Inter-American Affairs and became implicated in the Iran-Contra affair and sentenced for withholding information from the Congress which had previously banned the funding of Contras who were fighting against the revolutionary
} 
do well to consider helping the Turks raise the level of education and professional training of their police forces" (Abrams, 1984).

In this way, Turkish officials and their apologists attempted to fix the problem as one of education and training, related to long standing handicaps of underdevelopment. Torture was some sort of an accident that was unfortunately bound to happen due to the lack of resources, training or education rather than a political tactic to discipline the population. Unlike the military administration which regarded torture incidents as disconnected cases of accidents or personal cruelties, the new approach to torture evaluated it as a problem of underdevelopment and lack of liberal values. This shift in thinking was significant in terms of the solutions it implied and the possibilities it gave rise to. Whereas torture as personal cruelty implied individualized intervention in psychological well being of officers or judicial action, torture as underdevelopment and illiberalism implied the necessity of training programs, capacity building, transfer of Western policing practices ${ }^{70}$ and dissemination of liberal values. The language was also significant in terms of the unfolding of anti-torture strategies in Turkey. As seen in the examples above, the gap between the adherents of accusatory strategy and Turkish state was wide. The new thinking, however, made it possible to engage with actors who did not see torture as an expression of fascism or state crime but as a problem of bureaucratic and technical incapacity. Therefore, it gradually became possible to cooperate with the actors of what I called preventive strategy. In contrast to the accusatory strategy,

Sandinista government in Nicaragua (History Commons, n.d.). It is notable that a figure like Abrams made recommendations for improving human rights in Turkey.

${ }^{70}$ This is not to say that all police practices in the West comply with human rights. The difference between the styles of British policing in the mainland and in the colonies is well known (Sinclair \& Williams, 2007). This is not only a historical issue though, as the unreasonable searches, arbitrary detention, excessive use of force and mass arrests by the Canadian police during the recent G20 summit in Toronto makes clear (Canadian Civil Liberties Association, 2010). 
preventive approaches emphasized the enhancement of bureaucratic and technical capacities, and this set of ideas were in harmony with the new thinking. Moreover the new thinking not only made possible the shift towards technicalization of police work but also cooperation with international actors such as in twinning projects.

The Özal government embedded the question of torture within a context of fight against terrorism for the survival of the state. Torture was abhorrent yet this practice was not unexpected given the difficulties, especially the terrorist tactics of Kurdish guerillas in the eastern parts of the country. Despite the shift towards underdevelopment and the lack of liberal values to explain police misbehavior, the civilian administration pursued the practices institutionalized under the military regime. The "precautions to prevent torture" were similar to the efforts under military rule. That is to say, the emphasis remained on the better implementation of the legislation in place and commanding the officers to comply with the laws rather than devising technical solutions to prevent torture and impunity. The main tool used by the government to prevent instances of torture was the circular that was signed by the relevant minister or high-ranking bureaucrat and sent to the security personnel through regular bureaucratic channels. Circulars were typically issued following a publicized instance of ill treatment and usually listed the legislation in force and urged more effective implementation of these laws (see Emniyet Genel Mudurlugu, 2000a).

The causes of torture were much different according to human rights activists. Amnesty International, pursued the accusatory strategy by consistently defining the treatment of detainees as "systematic torture" which implied that torture was a state 
policy implemented through out the country to both ordinary and political offences (Amnesty International, 1980).

In the mid-1990s, the political elite increasingly came to think about devising ways to steer the police behavior through technical improvements in police practice. This can be seen in Prime Minister Çiller's request from the High Advisory Council for Human Rights ${ }^{71}$ (İnsan Haklan Yüksek Danışma Kurulu). In urging the officials to find "a method of getting information without resorting to torture" (as cited in Milliyet, 1994a, p. 13), the PM had not only acknowledged that ill treatment was functional in law enforcement but also that torture was in a way due to lack of sophisticated methods or expertise. It was hoped that, the High Advisory Council as an expert body could solve this problem. In the report prepared at the request of the Prime Minister, it was pointed out that the main cause of the cases of ill treatment in Turkey was lack of proper professional training of the police officers ${ }^{72}$ (Basbakan Insan Haklari Basmüsavirligi, 1996, pp. 166-178). The main recommendations or the report regarded the interrogation process and the training of the police officers. Concerning the interrogation, the report emphasized that interrogation required certain skills, knowledges and infrastructure such as ability to analyze information, psychology of suspects, evidence evaluation and interrogations rooms with special technical features. The training of officers, on the other hand, should be specialized and relevant to police practices. The report pointed out that interrogation without resorting to torture required that police officers sincerely want to do

\footnotetext{
${ }^{71}$ This advisory council was established under the auspices of State Ministry responsible for Human Rights and was active between 1994 and 1996.

${ }_{72}$ The report divided the causes of torture into three. Objective causes were: insufficient professional and ethics training; problems in employee rights, police recruitment, legislation regarding torture, physical environment; insufficient supervision. Subjective causes were: cultural habits, worldwide increase in aggressiveness, and prejudgments. The third was the negative professional habit of "old-school" style interrogations (Basbakan Insan Haklari Basmüsavirligi, 1996, p. 168-169).
} 
their job without violating human rights and have the sufficient knowledge to do that. In line with this, report also recommended values education for officers and adoption of an ethics code. Yet overall, the emphasis was put on technical capacity and training of the police officers. In total, the report listed 43 concrete recommendations. Of these recommendations, nine of them related to places of interrogation (e.g. dimensions, lighting, color of walls, furniture of interrogation rooms); 14 of them related to "conditions of interrogation" (e.g. persons authorized to interrogate, videotaping, training of interrogators, medical examination after the interrogation); 12 of them related to "objective aspects" (e.g. access to lawyer, conduct of interrogation, preparation of statements); and eight of them related to education and employment of police officers (e.g. special schools for chiefs of police, selection of police cadets, ethics code). Then, the trend towards technicalization of police work and emphasis on technical capacities was also apparent in the recommendations of this report.

Several reasons can be given for this change in direction. The pressure from the European Parliament whose assent to the Customs Union was conditional on improvements in the area of human rights can be cited as a significant factor. The warning of the European Committee to Prevent Torture also seems to have been influential. The CPT was undertaking visits to Turkish centers of detention and prisons since late 1990 and transmitting its observations and recommendations to the Turkish government. As it would later appear (see CPT, 1996), the expert body was becoming impatient with the lack of progress on matters brought to the attention of Turkish authorities. The government was notified that a public statement on Turkey was imminent unless effective safeguards against torture were taken (Yinanc, 1995). Public 
statements by the CPT were made very sparingly, and aimed to embarrass the country in question. ${ }^{73}$ Yet as argued in the introduction, these normative pressures are not always sufficient to understand the content of the reforms to eradicate torture in Turkey. The calls for compliance with the right to be free from torture were mediated and picked up by political actors and interpreted in certain ways.

While the government seemed to rethink its attitude towards abuses of human rights, the cooperation of the armed forces and the police was also necessary for the shift to be effective. It was the security establishment itself that would implement the reform schemes of the government. Although this dissertation does not cover human rights abuses by members of the armed forces or the schemes developed to combat them, the position of this body is worth mentioning in terms of its overall influence on the making of security policy and human rights reforms. The armed forces then had an autonomous position, exerting considerable influence on many aspects of the government policy through the National Security Council. The 1983 Constitution required the government to give priority to the recommendations of this body. Besides this "legal" requirement, frequent public declarations and statements by the military officers on policy issues and their popular standing among the population complicated the prospects of human rights reform. The role of the army in domestic intelligence and security operations also entrenched its political autonomy (Cizre-Sakallioglu, 1997). The high command of the army was in favor of a hard-line approach towards terrorism and viewed proposed human rights legislation as concessions to the terrorist PKK. For instance, in April 1995, armed

\footnotetext{
${ }^{73}$ Between 1989 and May 2011, the CPT made six public statements, two of which concerned Turkey. See
} CPT (2010a). 
forces deputy chief Ahmet Çörekçi said "we will finish terrorism soon but we are being held back by democracy and human rights" (as cited in Bell, 1995).

In terms of the relations with the government, the police organization was in a different position. It did not enjoy an autonomous position within the state apparatus as the armed forces did, and did not have institutional venues to exert its influence on policy-making. It did not have a chair in the National Security Council. Still, police officers and high-ranking police professionals made it known that they were against reforms to improve human rights. The funerals of fallen police officers were used as public occasions where the police showed their resentment through slogans like "down with human rights" (Bora, 1994/2006; Radikal, 2000). As a result of years of political influence on the police organization, the institution was dominated by right wing and radical nationalist officers (Caglar, 2003). Adherents of these ideologies saw the fight against Kurdish secessionism and other left-wing groups as a matter of survival of nationhood. The state should do whatever was necessary to prevent the destruction of the country. Any legislation to improve human rights and limit the discretion of the police was thus seen as concessions and appeasements to those who wanted to destruct the Turkish state. Yet this ideological stance reminiscent of the "state of exception" remained a belief system or perhaps a means to boost "internal morale" (Mann as cited in Osborne, 1994, p. 290) that was functional for the cohesion of some sections of the police department (especially the Anti-Terror teams).

The unpopularity of human rights reform in the security establishment seriously limited the options and left the government with a dilemma. On the one hand, the Customs Union with the EC was an important priority that required improvement in 
human rights area; on the other hand, for many years, ill treatment was tolerated and the police organization was almost left to its own devices when dealing with issues of public order. To complicate matters further, the policy of pursuing membership in EC and the hard "law and order" stance were both supported by the population at large. The security establishment had become almost dependent on the use of force to gather information that its renunciation could handicap operations of the security personnel. The government used various tactics to deal with the torture problem in police custody. To enroll the police department in this scheme, Minister of Interior appealed to the nationalist worldview of the officers by repeating the claim in ministerial circulars that allegations of torture were harming Turkish interests and international prestige as well as leading to heavy bills of monetary compensation. The police should be vigilant not to "give a negative impression" (e.g Icisleri Bakanligi, 2001). However, a more effective way was the construction of torture problem as a problem of evidence gathering that could be overcome by skillful interrogation and professional expertise. The problem could be solved through promotion of technicalization of police work and not necessarily through the dissemination of liberal values in the police department. This was also in line with the idea that underdevelopment of the country was the main reason for the persistence of problems of ill treatment.

Signs of a trend towards framing torture as a problem of evidence gathering, or more generally a problem of the efficiency of the criminal justice system can be seen in a study undertaken by Sulhi Dönmezer and Feridun Yenisey in 1995 (Dönmezer \& Yenisey, 2002). The late professor Dönmezer was one of the doyens of criminal law in 
Turkey (Turk Ceza Hukuku Dernegi, n.d.), frequently consulted by the government. ${ }^{74}$ The study was a statistical-empirical study of the efficiency of Turkish criminal justice system (CJS) which analyzed close to 1200 penal law cases in Istanbul courts, excluding terror-related cases. ${ }^{75}$ Dönmezer and Yenisey defined the criminal justice system as an "interconnected network of decisions" that involved police, prosecution, judge, appeals court and penal institutions as actors whose decision affected the decision of the other in a profound way (Dönmezer \& Yenisey, 2002, §3). Efficiency of the system, in turn, was defined as the capacity to countervail crimes committed with sanctions in a precise, equal, decisive and fair way. The authors pointed out that the purpose of the study was to consider the efficiency of the CJS and make some recommendations. Most of their 68 recommendations related to the measures to speed up the CJS and 16 of them directly related to police functions. Especially the gathering of evidence by the police was a vital activity within the system that greatly influenced the achievement of criminal justice (Dönmezer \& Yenisey, §32). Better preliminary proceedings, in terms of preparing high quality evidence files, were essential for the efficiency of the CJS.

On the question of torture, Dönmezer and Yenisey frequently took a defensive position arguing that they found only a few cases $(0.3 \%$ of the files they studied) where suspects claimed that they had been tortured. This demonstrated the groundlessness of the allegations of systematicity of torture. The authors suggested that new libel laws that would help the police to prosecute "liberal and Marxist press" that spread false information and tarnish the image of the police and individual police officers should be

\footnotetext{
${ }^{74}$ Between 1950 and 2001, he participated or chaired various official commissions for the drafting legislation and was one of the members of the commission that drafted the 1961 Constitution in Turkey. Yenisey was a student and a life long collaborator of Dönmezer.

${ }^{75}$ It should also be noted that the study contributed to what I called the new empirics of torture.
} 
incorporated into the penal law. Nevertheless, authors implicitly conceded that there were problems in the adherence of the security personnel to human rights. The police, the researchers concluded, was relatively successful in recognizing crime and finding out the suspects but "it was seen that this high proportion of crimes solved came as result of a heavy bill" (Dönmezer \& Yenisey, §331). The authors suggested some "basic measures to eliminate alleged torture practices" in Turkey. One was to increase the use of criminal evidence other than suspect statement. According to these experts:

The implementation of the [1992] amendments to the criminal procedure, the rejection of torture, the obligation to adhere to... the human rights of suspects during interrogations will not preclude the discovery of crimes and evidences only if there are law enforcement personnel who can use and acquire expertise on scientific data. (Dönmezer \& Yenisey, §337)

In this way, the experts emphasized that dissemination of liberal values was not the only way to bring about compliance with human rights. When the police work was technicalized, the political problem of the propagation of human rights to the police was by-passed. Dönmezer and Yenisey sought to accomplish this principally not through shaping the "values" of the police officers, but through showing them a new and better path to their professional interests. This indicates that coercion and persuasion to adopt norms are not the only mechanisms available for the enrollment of actors into a network. As mentioned in Chapter 1, the political science literature on compliance and norms often argues that changes in state behavior come as a result of dissemination and adoption of norms. For instance the Ukrainian officials were convinced by the European experts that capital punishment is a bad thing, through discussions and persuasion (Bae, 2008). Or 
Turkish officials were socialized into European norms of border management through constant contact with EU bureaucrats (Kirisci, 2007, p. 10). This case, however, points out towards the different conclusion that the behavior of officers were not shaped through values education or ideas but through guiding the police towards certain practices. The political problem of reconciling contradictory demands of human rights compliance (from EU and other actors) and combating terrorism leads to this by-passing solution. The two experts argued that, the primary professional interest of the police was not receiving better coverage from international human rights organizations, but the enforcement of law and discovery of crime. This could be better and more efficiently accomplished through mastering methods of evidence gathering and evaluation. It seems that the experts thought that this outcome would be optimum in that it would both help convict the criminals and secure compliance to human rights by default.

Another measure that was suggested was the transformation of the "judicial culture" of the police in a way that would make human rights a "building block" of the practice. Indeed Dönmezer and Yenisey worked to effect changes towards this end in cooperation with the government. They not only helped prepare a new circular governing the detention of suspects (Dönmezer \& Yenisey, §321), but also toured the country with officials from the Ministry of Interior and Justice to lecture the law enforcement personnel about how to do policing without violating the rights of the individuals. In this vein, the authors argued against the punishment of security personnel: "ensuring that police conforms with the law is better than punishment, punishing violations is not enough to maintain public confidence in the police." They instead suggested governing police behavior through the formation of a notion of "honor of the profession," 
establishing adherence to legal and professional rules as criteria for promotion, control and monitoring by the public prosecutors and protection of the police from the attacks of the press. Thus, they envisioned a scheme that relies on internal mechanisms of discipline as well as subject formation but protects the image of the police organization and the individual officers from criticisms of the "liberal and Marxist press" by activating criminal libel legislation. A broader analysis of interventions in the police identity will be provided in Chapter 5 .

As seen above, there have been changes in the criminal procedure law in 1992. At the time, these changes were considered as revolutionary and provided a new framework within which the police and prosecutor behavior had to operate. The new law was accompanied by the exhortations of legal experts, which toured around the country to explain new legislation and instill the new emphasis on technicalization of police work (Ciloglu, 1996; Emniyet Genel Mudurlugu, 2000b). The effects of these incitements were becoming visible in the way interrogations were conducted by police officers. Not only the practice of interrogation was increasingly projected as a technical exercise, those who practiced it were seen as expert officers differentiated from others by certain qualifications.

As I argued in the introduction, the development of an anti-policy against torture can be read in conjunction with the productivity and inventiveness of relations of power. One of the initial operations for an anti-policy would be the constitution of a field of activity as a problem, thereby constructing it through discursive practices. In the years following the 1980 coup, we see the emergence of interrogations of suspects as a highly problematical domain. The emergent discourse on interrogations complained about a lack 
of supervision and regulation of this practice. Indeed, a code of conduct for interrogations was not available until 1991. This point was brought to the attention of Turkish authorities by the Council of Europe's CPT in its September 1990 report (CPT, 1990a) which opened the door for technicalization of interrogation. Government officials prepared a code of conduct for interrogations, formalizing this procedure and determining the "interrogator's qualifications" as "thorough knowledge of the subject, experience, understanding of the psychology of guilt and patience and cool-headedness" (as cited in CPT, 1990b, p. 12). The redefinition of interrogation as an expert practice that had to conform to human rights was a way to limit the number of people within the police organization who could conduct interrogations. The 1992 amendments and the emphasis on evidence gathering further shaped police behavior as can be seen in a series or interviews conducted by the Hürriyet newspaper in 1997 with several police officers, including the acting director of Anti-Terror Department of the Turkish police. In the interview, director Ahmet Demirci argued that:

People who conduct the interrogations have certain qualities. It requires a different kind of merit. Not everyone can do that. You have to be eager and enthusiastic. One has to be committed to service and self-sacrifice.... Not all police officers can do interrogations. People who conduct the interrogation have to have detailed information about the issue. (As cited in Aydin, 1997a) This very act of the interview with the press has to be considered as an important event in its own right. At the time, Turkish police officers other than the head of the General Directorate of Security hardly gave any interviews to the journalists. The military junta had installed a sort of permanent "gag order" by banning public employees 
from "giving information or making statements" to the press in 1982 (Tanor, 1994, p. 168) and they needed written permission from the relevant Minister to give any kind of statement to the media (Article 15 of Law No. 657). The information on current incidents given by the officers to the press on an anonymous basis constitutes a large exception to this rule. So, one can conclude that the series of interviews given by the police officers itself constitutes a message by the organization and the government. The interviews aimed to make public the "renewal" of the police.

It was indicated in the Hürriyet interviews that in 1997 a book by John E. Reid et. al. (Criminal Interrogations and Confessions) was translated into Turkish and distributed as a guidebook to the officers who carried out interrogations. This new model of interrogation was not only in line with human rights but it was effective for law enforcement and discovery of crime. Therefore the reform program was not only about changing the "moral dispositions" of the police officers but also about governing them through their professional interests in apprehending criminals and securing convictions. Moreover, the Anti-Terror Department conducted in-service training for its officers to inculcate new methods of taking statements from suspects. An expert interrogator mentioned that he conducts interrogations "not according to the age old methods, but in line with the European standards." The fact that he said that he "represents the reformist wing" of the police organization is also a sign that the renewal that was taking place is more than just change in the operating procedures (as cited in Aydin, 1997b). The transformation of police was associated with the rise of a reformist wing in the organization. 
These interviews also confirm the observation that torture and ill treatment were increasingly considered as a problem of underdevelopment. Frequent and scattered references in these interviews suggest that police officers understood the work of reforming police procedures as development and approximation to American and European ways of doing things. For instance, the frequency of police ill treatment in Turkey was high "when compared to the Western standards," "primitive interrogation methods were more prevalent in the rural areas," police were adopting instruction manuals "which are accepted as basic reference books in USA and Britain," and it was emphasized that there were many new officers who were university graduates or had education credentials obtained in Western countries (as cited in Aydin, 1997a). In this way officers defined the new procedures as advances in the political and social development of the nation.

In this context, the government heeded the advice of the Dönmezer and Yenisey that preliminary investigation procedures had to be strengthened for the sake of the criminal justice system. If the police and justice system as a whole could rely more on evidence other than the suspect statements and interrogations, this could lead to more credible verdicts, less open to challenges at the higher courts and less problematical in terms of human rights. Thus, the government started to promote the formula of "finding out the suspect through evidence rather than finding evidence through the suspect" in criminal justice. "Finding evidence through suspect" summarized the working methods of police. As Eryilmaz observed:

Given the long detention periods... in practice arrests are often made on the ground of general suspicion or no evidence or suspicion at all, it is difficult to say 
that the sole purpose of the arrest is to bring the suspect before the justice of the peace. Rather, its purpose is to get the suspect into a police station where detention, questioning and other forms of investigation follow. (Eryilmaz, 1999, p. 148)

This working method inflated the number of suspects and the extent of abuses, as the police detained all who they thought were related to a crime in a way and tried to extract as much information as possible. These bits of information were then used to make further arrests until police thought they found the real suspects. This formula conceded that statements taken in interrogations were not a good way to produce evidence but the latter had to be found by relying on technical methods such as surveillance and telephone tapping.

This agenda for evidence based investigations was strengthened with the fight against the mafia in Turkey whose links with the high level security bureaucrats and government was revealed in a car accident ${ }^{76}$ in Susurluk in November 1996 (Gunter, 1998). The financial and other operations of the underworld could be detected with the help of forensic methods. The formula itself can be traced back to 1998 when the Minister of Justice Hasan Denizkurdu informed the press about a draft legislation to combat organized crime (Milliyet, 1998). However, the greater push came from the next government where the Minister of Interior Saadettin Tantan became an ambitious promoter of this approach during his time in office between 1999 and 2001. He formed a commission to draft a law on organized crime with the participation of experts such as

\footnotetext{
${ }^{76}$ In the car were an MP from the southeastern Turkey (who was the leader of a tribe that assumed paramilitary duties in the region), a former nationalist militant travelling on a fake ID, convicted for drug trafficking in Switzerland and being "sought" by the police for a massacre in Ankara in the 1970s, and a high ranking police officer who was formerly deputy chief of Istanbul Directorate of Security.
} 
Dönmezer and Yenisey who were the authors of the above mentioned 1995 report (S.

Tantan, personal communication, May 7, 2008). According to Tantan, "there was

[insufficient] legal basis for finding suspects through evidence" until the 1999 Law on

Prevention of Benefit-Oriented Criminal Organizations (Law No. 4422) was adopted in

the parliament. This new law made it possible for the police to gather more evidence

through the utilization of techniques such as telephone tapping, use of secret agents and

informants. When these techniques were used, there would be no need for torture since

"the evidence itself would shout [the truth]" (S. Tantan, personal communication).

When the Justice and Development Party (JDP) came to power in late 2002, one

of the first promises it made was regarding human rights and especially torture. ${ }^{77}$ The

party declared "zero tolerance to torture" as its basic guiding philosophy. ${ }^{78}$ The approach

of JDP was different from the previous governments in Turkey, especially in terms of its

conception of the relationship between human rights and fight against terrorism. Unlike

the previous administrations, the "conservative democrats" did not see human rights as a

set of principles that would be implemented after the fight against terrorism reached

"victory" or that human rights would be practical only after Turkey had advanced in its

\footnotetext{
${ }^{77}$ At the time, despite the high percent of the vote it captured, large sections of the Turkish population was suspicious towards this political organization mainly because it was formed by cadres from the Welfare Party (Refah Partisi). This party was forced to resign from government by the military in a slow motion "post-modern coup" in 1997 and was later closed down by the Constitutional Court. This suspicion was also partly shared by the international community. JDP sought to overcome the problem of legitimacy by declaring a program of reforms and democratization, which was also necessary to pursue integration with the European Union. Moreover, JDP's leadership, having its roots in political Islam, found the universal language or democracy and human rights useful for advancing their agendas and shield themselves from military interventions and accusations of Islamic reactionism (Dagi, 2006).

${ }^{78}$ This phrase was similar to "zero tolerance to crime" which expressed a law and order posture, where law enforcement authorities persecute all crimes without regard to their significance or consequences. Every offense, however minor, should be pursued by the police so that offenders would not be encouraged to engage in more crime (see Wilson, 1985). However, while JDP was determined to improve human rights situation in the country, its zero tolerance to torture did not mean a strict punitive stance towards acts of torture.
} 
political and social development. Rather it was seen as a necessary component of the fight against terrorism. Human rights violations were being abused by terrorist organizations to portray Turkey as a repressive state. Further, the violations were being useful arguments for recruiting new people for the PKK. The state, by eradicating the violations, could nullify the "excuses" the PKK was exploiting to maintain its activities (see for instance Ates, 2010). The positive attitude of the JDP was not simply an instrumentalization of the human rights for other purposes. The previous political parties of this movement was closed down by the Constitutional Court and its leader R. T. Erdoğan was imprisoned and banned from political activity on charges of inciting hatred. The conservative democrats represented a new generation in the political Islam movement in Turkey that came closer to notions like democracy and human rights (Dagi, 2006).

The JDP government was confronted with the dilemma of the previous governments as well: How could the government transform and reform the practices of the police without losing the allegiance of police officers? The government was also faced with requests from the European Union to take concrete measures to improve human rights situation. The JDP needed the EU "anchor" to sustain the support of the international community due to its controversial pedigree of political Islam. One advantage of the JDP was that it was a right wing conservative party with many nationalist supporters within its ranks. Their nationalist-conservative stance was in line with the members of the police organization who had a similar outlook.

JDP found a way out of these problems by maintaining the previous projects of technicalization of police work and emphasis on the training of police officers. The 
novelty of JDP's approach was the adoption of a "policy of care" towards the police organization while simultaneously adopting legislation to improve human rights. The government moved to remove the barriers against prosecution of police officers. This was complemented by a move to improve working conditions and economic benefits of police officers (Hürriyet, 2002). In this way, the government sought to maintain the allegiance and cooperation of the police while reforming it at the same time. The government also changed legislation to ensure that torturers got prison penalties (instead of paying fines) and that these prison sentences are not deferred. The reform of the department and prevention of torture were joint efforts. For instance, in a 2003 circular the Ministry of Interior ordered more attention to investigations of the crime of torture while requiring the police chiefs to establish a suitable working environment for the officers by limiting their working week to not more than 40 hours and providing psychological group therapies to all officers whose work require contact with citizens.

A new Turkish Penal Code (Law No. 5237), and a new Code of Criminal Procedure (Law No. 5271) came into force in 2005. These legislations contained significant improvements: The maximum period of detention was reduced, the right to access to lawyer and relatives was reaffirmed, torture was defined in the code and heavier penalty for torture was instituted (Amnesty International, 2007b). However, human rights experts pointed out that impunity was still a problem. According to Erdal, the "policy of impunity" was achieved through a series of "legal, judicial, administrative and de facto mechanisms" (Erdal, 2009, p. 54). Unlike the previous Turkish Criminal Code, the new code made suspension of sentence and administrative fine possible for crimes of ill treatment. Moreover, the code included similar crimes with less punishment, such as 
torment, misconduct in office, or negligent injury making it possible for the offenders to receive fewer penalties for ill treatment (Erdal, p. 55-56). A report prepared by the Human Rights Inquiry Commission of the Turkish parliament substantiates Erdal's concerns. The commissioners report that between 2003 and 2008, 35 legal cases of torture and ill treatment has been brought against 431 police officers in Istanbul. None of the police officers have been found guilty in these cases, prompting the commissioners to be skeptical towards the effectiveness of investigations (TBMM Insan Haklarini Inceleme Komisyonu, 2009b, p. 58).

In terms of the political rationality of anti-torture policy, this suggests that the government's method of choice in combating torture was not necessarily a strict regime of punishment for the officers. In case of such a disciplinary measure, the government would run the risk of alienating the police department. Indeed, the effects of such an alienation were visible in the aftermath of the adoption of the new Penal Code. In 2005, newspapers reported that police officers failed to intervene in certain incidences on the grounds that they did not have the legal power to do so. For instance, in the southern city of Adana police were notified of a case of break and enter for theft. When the officers rushed to the scene, they refrained from entering the house saying that they did not have the authority to do so. When asked about this incident by journalists, the Minister of Justice Cemil Çiçek weighed in that the police already had the powers necessary to intervene in such a case and not doing so was due to lack of knowledge of the new criminal procedure. Others, however, including one of the authors of the new code of procedure argued that these incidents were "deliberate resistance" to the new law rather than simple neglect (Tahincioglu, 2005). Several police officers that I have interviewed 
also confirmed the resistance theory (anonymous police officer, personal communication, May 5, 2008 and anonymous police official, personal communication, June 26, 2007).

Whether these cases were attributed to passive resistance or pains of transition to a new procedure, it was certain that the actions of police officers could put the government in a difficult position in terms of law and order in the society. Maintaining the cooperation of the police should be seen as a condition to be achieved through certain practices rather than being readily available. Thus, antagonizing the police department through strict discipline was not an option for the government, who sought to secure its power. In combating torture and ill treatment, the JDP adopted less direct methods. These included the diffusion of crime scene investigation (which will be dwelled upon in the next chapters) and technological devices such as the cameras in police detention centers and police cars. Monitoring police officers through these impersonalized means not only afforded a constant surveillance of police officers, but also depoliticized supervision. The conventional means of supervision through superintendents could be seen as a political instrument since in cases of unusual investigations, superintendents are assigned by the minister. The effectiveness of supervision by the prefecture or police chiefs was in doubt. In this case, installments of cameras erased the subjectivity of supervision by making this practice less dependent on the personal opinions and cooperation of the superintendent. The gaze on the police did not belong to a superintendent sent in from the central government but to the cold and objective technical device of camera, the output of which could be more credibly verified and replayed. 


\subsection{Conclusion}

The above account allows me to make three points. First, we have seen that the Turkish state was constituted as a project of modernization and Westernization and thus human rights, as quintessential values of the Western civilization, were seen as an important part of the Turkish political regime. Even though the full application of human rights was often deferred and civil rights were at times practically suspended, these values preserved their status as esteemed principles. At the very least, this made the engagement of Turkish officialdom with human rights organizations possible. At the same time, it created the grounds for the application of accusatory strategy to the Turkish case. Without the commitment of the state to human rights values, the shaming tactic of the accusatory strategy would be far less meaningful.

Second, the chapter has explored the shifting political rationalities of the antitorture policies. The chapter has shown that torture in Turkey has initially been problematized within the context of an accusatory strategy which gave rise to state efforts to combat against allegations, rather than the practices of torture itself. We have seen that from the 1990s on, the political elite shifted towards a new framework to know and intervene in problems of torture. We have also seen that this new framework shared many tenets with what I have called the preventive strategy against torture: it has conceptualized torture as a problem of state (in)capacity; it often refrained from putting a too heavy emphasis on punishment of torturers; saw the enhancement of technical capacities and skills as a solution and did not rely too much on shaping the ideological and normative maps of the police officers. This shift has made possible a new way of 
engaging with the international community in the form of international assistance, which forms the subject matter of the chapter on twinning.

The third point is that, in the Turkish case, the technicalization of police work has not always been motivated by a search to find ways of preventing torture and ill treatment. As the interviews suggested, one of the major raison d'êtres of technicalization was to advance the fight against crimes, especially organized crime which was seen as impenetrable through traditional police methods. To combat against organized crime, the criminal justice actors required sophisticated surveillance and evidence gathering methods which also strengthened the agenda for "evidence based investigations." This type of investigations, in turn, became the main means to prevent torture and ill treatment by making confessions less relevant for law enforcement. 


\section{CHAPTER 4: THE PARTICIPATION OF THE POLICE IN ANTI- TORTURE POLICIES}

In the 1980s and 1990s, the question of torture continued to be a formidable problem in Turkish politics. In the previous chapter we have seen how the government sought to handle this problem first by fighting against the allegations itself and then developing schemes to eradicate the practice by channeling criminal investigations through different routes. I touched upon some of the developments in the police but, overall, the focus remained on the government practices of responding to allegations of torture. This has shown that one of the main components of anti-policy of torture in Turkey was the enhancement of the technical capacity of the police department. This new framing helped secure the cooperation of the police department since it did not imply a campaign of police discipline and a drastic reduction of police powers. It has also enabled programs of harmonization with the European Union such as twinning projects, which will be our focus in the next chapter. In this account, the place, role and agency of the police department were mostly bracketed to focus on the efforts of the government. In this chapter, I highlight a different aspect of this story to argue that the police contributed to the anti-policy of torture especially from the mid-1990s on. The police took part in this anti-policy by associating with actors such as the government and the Council of Europe and by dissociating itself from the military. It should be noted at the outset that the identities of these actors were not fixed but changed in time. The identities were the outcomes of both self-definitions and negotiations with other related actors. In order to make this argument, I first provide some theoretical tools borrowed from the ActorNetwork Theory (ANT) and Bourdieu's field theory. After this brief exposition, I turn to 
the history of the Turkish police to understand the influences and claims on its agency. This is followed by an analysis of the conjuncture in the late 1980s and 1990s. This is a new period when new actors like human rights NGOs, the EU and the Council of Europe enter the picture with their accusatory and preventive strategies. The account then concludes with the association of the police (or some of its components) with new networks in part through a redefinition of its identity.

\subsection{Networks and Fields of Power}

In the introductory chapter, I noted that one of the ways of securing the implementation of human rights is the establishment of an assemblage that is composed of both things and individuals. This notion of assemblage is already prefigured in studies of governmentality which see power as a strategic situation accomplished through the articulation of practices dispersed throughout the body politic, rather than something possessed at the center. For instance, in advanced liberalism, the exercise of power by the state to attain welfare of the population happens through the mobilization of citizens to take responsibility for their own life by becoming active and entrepreneurial citizens (Rose, 1999b).

The question that concerns us here, however, is how these associations between different actors are formed. In order to understand this, we need to look at Callon's (1986) "sociology of translation" outlining the moments of construction and maintenance of power relationships. The construction of a durable relationship of power can be divided into four moments: problematization, interessement, enrolment and mobilization. In each moment, the original project is negotiated and modified so that it can be taken up by others. This is why most processes of diffusion are indeed processes of translation. In 
the moment of problematization, contenders define the problematic situation, identify the actors and define their interests. In this moment, contenders try to show that cooperation with them is necessary to overcome the problematic situation. In the moment of interessement, the contenders attempt "to impose and stabilize the identity of the other actors" (Callon, 1986, p. 207-208) that were defined in the problematization. In this moment contenders seek to extract the others from their context and dissociate them from other actors who have an influence on them. According to Callon, this justifies the choice of the word interessement, which means being in between. The contenders get in between the actor they want to influence and other actors and try to isolate them from others' influences. This moment of putting into practice "the theory" defined in problematization often involves conflict and contestation. The third moment of translation is called enrolment. When enrolment is achieved it means that the interessement is successful and the entities accept the role given to them in the moment of problematization. To accomplish enrolment, contenders negotiate with others and try to show that their idea works in practice. The last moment is called mobilization. In the process of translation, it is not possible to bring all the relevant actors in the problematization, interessement and enrolment processes. Contenders necessarily work with the representatives of the actors. The will of different actors are rendered mobile through devices such as the election of spokespersons, or inscriptions of dispersed wills into reports, articles, etc. In this way, the contenders can show that they are the macro-actor that represent and speak in the name of other micro-actors and thus stabilize the actor-network. Certainly, this is not to say that translations are accomplished once and for all. There are always moments when other 
contenders seek to redefine the interests of actors, when the schemes fail to function or the representation of the spokespersons are contested.

As Callon (1986) argues, the process of translation involves multiple negotiations, conflicts and contestations between the contenders and other actors. Although this perspective is useful for recognizing multiple agencies, Callon views the network mostly from the vantage point of the contenders. The "others" are not treated as passive recipients but are often only responsive to the problematizations and interessements of the contenders. To highlight the agency of "others" in the network and see that they have an agenda of their own, we can bring in the concept of the field, an arena of struggle and competition between actors. Bourdieu defines the field as

A network, or configuration, of objective relations between positions. These positions are objectively defined, in their existence and in the determination they impose upon their occupants, agents or institutions, by their present and potential situation (situs) in the structure of the distribution of species of power (or capital) whose possession commands access to other positions... (Bourdieu \& Wacquant, 1989, p. 39)

Bourdieu offers the concept of field as an alternative to the heuristics like institutions and levels of analysis. Just like Foucault prefers to use the concept of practice to break free from conventional categories of social analysis, Bourdieu employs the concept of field to uncover relations that are not visible when categories that are already constructions are used to carry out analysis. Thus, rather than talking about the police institution we can discern a field of security where the players include not only the police officers but also other actors such as the army, gendarmerie, and security experts. What 
brings them together and what sometimes counterposes them is the capital specific to the field. In the case of security, this can be legitimate monopoly of violence, knowledge regarding threats, spaces to supervise, or crimes to investigate (Bigo, 2000b).

Competition with other actors may result in conflicts between actors but ultimately this reaffirms the legitimacy of the game and the goals pursued (Bourdieu, 1987, p. 823).

My use of the concept of field eschews its objectivist conceptual baggage that reflects Bourdieu's search for a middle way between structuralism and methodological individualism. According to Bourdieu, the objective positions of the actors in the field are hierarchically structured by the type and amount of capital they hold. However, in line with Didier Bigo, I think that positions of the actors in the field, which structure their practices, can be modified through the agency of actors themselves. This can be seen in the context of the transformation of the field of European internal security as elucidated by Bigo (2000b; 2001). He shows that European security professionals, through the utilization of their monopoly of the production of truths regarding threats, networks of cooperation enabled by European integration and technologies such as the Europe-wide databases of immigrants and criminals, have successfully instituted a transversal field of internal security. According to the accounts of these security professionals, the end of the Cold War has ushered Europe into a new period of insecurity where immigration and immigrants have been constructed as threats to security and linked with drug trafficking, mafia and the rise of crime. By connecting the security of citizens to presumed threats originating outside the nation-state the professionals of security managed to expand their mandates, enlarge their constituency, advance their position in the field and boost their significance for the public and politicians. The success of security professionals such as 
the gendarmerie and police anti-terror teams came through a challenge to the knowledges of and at the expense of armies and urban police departments who were focused on traditional types of security threats. Bigo also emphasizes that this state of affairs was not objectively caused by the end of the Cold War but constructed through the agency of security professionals (Bigo, 2002).

Equipped with the concepts of translation and field, the chapter now turns to the history of Turkish policing and looks at the construction of relations of power. To understand the transformations in the 1990s and the participation of the police in the antipolicy, we need to extend to the late $19^{\text {th }}$ century when the security of the Ottoman Empire is problematized and the need for a separate security establishment is emphasized. The way the police was established in these years was more or less successfully maintained throughout the years with some modifications. Without understanding this "original" actor-network, it would be difficult to grasp the novelties.

\subsection{The Police and the Army: A "Brotherly" Relationship}

The formation of police forces on the European continent can be traced back to the emergence of raison of state as a form of political rationality in the late $16^{\text {th }}$ century. According to Foucault, this new rationality did not aim to control the territory and thus bolster the sovereignty of the ruler but to accomplish the state's domination over the population and its maintenance (Foucault, 2007b, p. 238). The frame of reference of the reason of state was not the divine or the natural order but the integrity, tranquility and peace of the state. One of the central problematics of this rationality was the expansion of the state (Foucault, p. 289). The expansion of state required tactful conduct: Domestically, social forces that were necessary for the expansion should be secured so 
that they did not lead to a decline of the state. Internationally, the expansion had to reckon the existence of other states that also wished to expand their forces. ${ }^{79}$ The reason of state provided the political rationality for the growth of the police as a method that reconciled the welfare of the population and the enhancement of state power. It also pointed out to a differentiation between the military, revenue and internal order functions of the state (Valverde, 2007, p. 169). The establishment of a separate police organization in the Ottoman Empire in the mid-1800s nicely fits into this framework. In the $19^{\text {th }}$ century, the main concern of the Ottoman rulers was to preserve the integrity of the empire in the face of growing nationalist movements and the rise of the European powers. The establishment of a separate police organization would serve this purpose in several ways. The rebellions and resurgence of the nationalities within the empire could now be dealt with an agency that specializes in internal ordering and relieves unnecessary burden on the army. It would also bolster the Ottoman claim to participate in the European balance of power by proving that the state is able to maintain internal order (Ergut, 2000, p. 34). The peculiarity of the Turkish case was, however, the wish of the military to keep the police under its purview.

Throughout much of its history, policing in Turkey remained under the influence of the military. After the abolition of the Janissary corps and the establishment of an army modeled on the European examples, a ministry (Ihtisab Nezareti) was founded in 1826. This new body responsible for the security of the imperial capital formed the basis of a

\footnotetext{
${ }^{79}$ Foucault argued that the development of the capacities and resources of the state should be accomplished "without the break-up of the whole," (Foucault, p. 296) that is the European balance. The political technologies of this delicate balance were the military-diplomatic apparatus and the police. Here, the police was understood differently from its modern meaning. In the $17^{\text {th }}$ century it denoted "the set of means by which the state's forces can be increased while preserving the state in good order" (Foucault, p. 313). In line with the idea of balance of power, the good domestic order of a state was a concern for all participants in the European equilibrium since a state that was internally weak could lead to the collapse of the balance.
} 
police organization separate from the army. However, the chief of the police was responsible to the commander of the army, and the army constituted the main source of personnel for the police (Ergut, 2000, p. 98; Shaw \& Shaw, 1976, p. 46). In the vocabulary of the ANT, formal structures of hierarchy and human resources were utilized as techniques of interessement to weaken the links between the nascent civilian bureaucracy and the police. This pattern was maintained well into the Republican era. A separate police force was established in 1845 but was later fused with the gendarmerie which became responsible for the capital and the countryside. The military police regulation of 1869 recognized that the police function was administrative rather than military but still the organization was part of the military bureaucracy. In 1879 , the gendarmerie and the police were separated and the latter was put under the civilian Ministry of Police constituting the first civilian police force, but the military still interfered in police work. Later, the Ministry of Police was turned into the General Directorate of Security and placed under the Ministry of Interior in 1909. Nevertheless, the influence of the army on the force was sustained. This was reflected in the police training manual which regarded the military as "the elder brother" to be emulated and respected (Ergut, 2000).

The relationship between the police and the military had significant implications for Turkey's human rights record. As the military reinforced its guardian role from the 1960s on and became a significant actor in the making of external and internal security policy, its perspective on the national security was transferred to or imposed on the police. The increasingly repressive tone of policing that created the conditions for practices of torture in Turkey also needs to be considered from this perspective. The next 
sections survey this drift in policing and link it with the influence of the military in the making and implementation of national security policy.

\subsection{Policing in the 1960s: A Springtime of Repression}

In this section, I will limit myself to the discussion of two factors that shaped policing in this period: the military and the "national security" doctrine it propounded. In the first place, I will try to show how police was brought back into the orbit of the military. The significance of this development becomes apparent in my second point that from 1960s on, in part due to the influence of the military on Turkish politics, a "national security" doctrine became increasingly prevalent in the state apparatus. This doctrine meant that the political activism would be understood as an "insurgency" and the identity of the police would be redefined accordingly. The reduction of political activism to the status of "internal threat," in turn, implied that opposition groups would face an Agambenian state of exception that enabled practices of torture. Therefore both the influence of the military on the police and the national security doctrine are relevant for the anti-policy of torture. Let us look at these issues one by one.

When the military took power in 1960s, one of its main concerns was to reverse the policies of the DP that had come to power in 1950 . The DP was seen as a party that weakened the Kemalist principles such as state tutelage over the economy and secularism. The DP governments had emboldened the private sector who became increasingly assertive against the state bureaucracy and complained of state intrusion in the market (Ahmad, 1993, Chap. 6). The army also suspected that the DP sought to extend its influence on the bureaucracy including the police (Dikici, 2009). 
The practices of interessement that the junta used to dissociate the police from the political current that the DP represented were most visible in the regulation of police uniforms and personnel policy. The junta and the following government decided to use the police uniform to give the message that police was again a force of the republic and the regime (Tutkun, 2010). As Willem de Lint points out, police uniforms have long been seen as symbols of a military discipline in the police organization. In Ontario and elsewhere in the $19^{\text {th }}$ century, police uniforms were deployed to signify the isolation of the police constable from local interests and politics (De Lint, 1997). Similarly, subsequent governments in Turkey used the fabrics and insignia on uniforms as means of reminding who was in charge, and what the color of the political regime was. ${ }^{80}$

Personnel policy was also modified to reflect the priorities of the junta. The requirement of police training to enter the profession was suspended for a while and new officers were admitted provided they were physically fit and obtained security clearance. Unofficially, however, people known to be pro-RPP were given priority for entering the profession. This was thought to be necessary to erase the negative image of the police under DP governments (Oner, 2003, p. 15-16). The continuing link between the military and the police meant that the latter would remain within the orbit of the former.

The second factor that we pointed out was the rise of the "national security" doctrine that framed political activism. In the 1960s Turkey witnessed a massive process of urbanization (Altunisik \& Tur, 2005, p. 36). The proportion of urban and rural

\footnotetext{
${ }^{80}$ The DP, who came to power with a democratization platform and whose leadership has famously promised to turn the country into "little America" (Ahmad, 2003, p. 107) had changed the police uniform to look similar to the American police uniforms. Eight-point hat, regular jackets, necktie, and blue fabrics were adopted under this government. Following to the coup, the uniforms were shifted back to the pre-DP period: the regular jackets and neckties were discarded and eight-point hat was replaced with round top hat.
} 
populations has changed drastically. The urban poor and the university students formed the basis of the mobilization in these years. As mentioned in Chapter 2, the 1961 constitution enacted after the coup had provided a relatively suitable environment for social and political mobilization. Whereas earlier, political parties could be suppressed by a government decision or a decision by a court of first instance, after 1961 the Constitutional Court became the sole authority that could take such a drastic measure (Odyakmaz, 1996, pp. 232-233). The growth of the freedom to organize was reflected in the establishment of new organizations such as Workers' Party of Turkey in 1961 and DISK (Confederation of Progressive Trade Unions of Turkey) in 1967.

However, in a few years constitution came to be seen as a "luxury" for Turkish citizens as it was providing a too permissive political environment. The freedom to organize was originally provided as a bulwark against executive power, but political mobilization developed in ways that were unforeseen by the initiators of the coup d'etat. The corporatist rationality of Kemalism already approached political activism suspiciously. In this scheme, the population was understood as an organic whole composed of occupational groups functioning in harmony and individualist pursuit of interest and class antagonism were viewed as harmful (Parla \& Davison, 2004, p. 28). This rationality was complemented with the Cold War doctrine of "national security" where the main threats were defined as Soviet invasion and domestic leftist movements (Ganser, 2005). When the national security replaced the unity of the organic society as the object to be secured, a wide range political and social issues became security questions (Cizre, 2003). In Turkey as well as in Latin American countries, the dissemination of this doctrine resulted in a politics where the national security became 
the "yardstick by which all policies are measured" (Pion-Berlin, 1988, p. 385). The national security doctrine was transferred to Turkey mainly through the Turkish military. Following Turkey's admission to NATO in 1952, many high-ranking members of the Turkish military received training in the United States and the counterinsurgency manuals of the US Army, as military expressions of the national security doctrine, became textbooks for the Turkish officers. These manuals which constituted internal opposition as "participants in an international revolutionary conspiracy" (Pion-Berlin, 1988, p. 387) were later translated into Turkish in the early 1960s and became directives for the officers (Kilic, 2007. pp. 56-61).

The political demonstrations, protests and mass organizations were seen as agitations that acted contrary to the national interest. This was clearly seen in one of the first strikes of this period. In 1965, a strike over low pay in Zonguldak mines was suppressed by the army and air forces and two workers were left dead. The deployment of the military against a strike was indication that the event was viewed as a threat to national security. The incidents were described by the then Minister of Interior as a "communist incitement" yet this perception was not limited to the military and civilian bureaucracy: an influential editorial depicted the events with the keywords such as "spark, indignation, tumult" (Ipekci, 1965, p. 1) which could lead to widespread instability.

This understanding was institutionalized with the founding of the Society Police (Toplum Polisi) in 1965. The establishment of a riot police modeled on Western examples was first declared in 1963 in the government program (Berksoy, 2007). According to the law legislated in 1965 , this unit of police was 
established to prevent illegal movements on the streets and public squares, to avoid the partial or total destruction of the material and moral properties of society or persons through illegal strikes and lockouts, to prevent any illegal social incidents, which could have a bad influence on a large scale..., or to pacify them by using force whenever necessary. (As cited in Berksoy, 2007, p. 97)

The Society Police was a significant novelty in the police organization as it would become the most controversial unit of the organization and would remain one of the most visible elements in the eye of the people on the street. The riot police was constructed as a force against unwelcome political participation in the streets, a means to repress the visibility of opposition with tools derived from military arsenal. If the technology of riot control such as armored vehicles, police tanks, submachine guns, long-range weapons, gas bombs had any effect on the police officer conduct, this was certainly one of a radical alterity between the protestor and police and constitution of a relationship of enmity between the officer and the activist. Rather than riot control, the aim was policing of the society itself, hence the name of the unit.

The technology of policing was not the only element in shaping police identities. The essays in the vocational journal aiming at the police in its entirety sought to direct the officers towards repressive policing. Police officers were led to see the political opposition brewing in universities and factories as the population to be defused and dispersed. Rather than managing protests and retaining them within the limits of peaceful protest, officers were motivated to crush this emergent threat to the republic. The sole vocational journal of the organization, Polis, put the issue thus in its 1965 issue: 
As there is a significant increase in strikes, lockouts, sit-in-acts in countries that have a multi-party system, we could not wait any longer to establish this unit. The meetings of the students, the challenge posed by the worker gatherings, the raids of rebellious youth are unsettling the social order and it is necessary to make the Society Police strong enough to pacify them through the enforcement of law (Örge as cited in Berksoy, 2007, p. 96-97).

The law on the Society Police also afforded the organization certain exceptions to render it more violent in its confrontation with the masses. The 1934 police powers act did not require officers to perform orders deemed contrary to the legislation. These orders could be performed only when the superiors gave the order in written form. An amendment in 1965 changed this by outlining 13 cases where the requirement for written orders was removed and officers were cleared of responsibility. These cases were fairly broadly formulated as to include most of the street-level police work, and hence enabled a repressive policing style by absolving the officer from legal responsibility (Berksoy, 2007; see Vural, 1970 for amendments). A previous government attempt to absolve police officers from legal responsibility was annulled by the Constitutional Court in 1963 (Anayasa Mahkemesi, 1963).

The publications and speeches that addressed the police and changes in legislation sought to retain the police within the framework of national security. In this regard, the identity of the police also needs to be considered. As the ANT and studies of governmentality agree, the government of populations is achieved through the constitution of actor identities. As Thomas Osborne argues, the government of the state includes the government of the state personae: 
The field of government always presupposes a certain reciprocity between the problematization of a domain to be governed and the ethical characteristics of those who are to be subjected to government.... This 'ethical' component of government also embraces a certain attention to the ethical characteristics of those who govern, those who are constructed as the subjects of government; government is not just a question of shaping the conduct of others, but, also -as regards those who are the agents of rule- of bringing an ethical stylization of one's own conduct. (Osborne, 1994, p. 291).

The achievement of national security would be possible not only through the redefinition of political activism as "insurgency" and militarization of the police but also through the construction of a new police identity that was in harmony with the internal threat perceptions propounded buy the military. Police work was seen as part of the defense of the nation, understood in an overtly ethnic way (Berksoy, 2007). This conception invokes the notion of "race wars" that Michel Foucault (2003) uses to refer to violent struggles between differentiated groups in society. Police was constituted as one of the main protagonists of this war, waged against those that made an attempt on the life of the nation. This promotion of the police work as a service to the Turkish race was widespread, especially in the early years of the republic. Histories of the Turkish police was written and taught as a feature of the Turkish history understood as a race. The Turkish nation, for whom public order assumed a vast significance, arguably, had a functional police organization since the day it appeared on the stage of history in Central Asia. This narrative constructed a historical lineage extending from early Turkish khanates to modern Turkey via the Ottoman Empire. Other narratives took the early 
Ottoman Empire as the starting point (Istanbul Emniyet Mudurlugu, 2006). Despite the acknowledgement of a break in 1845 with the separation of the army and the police, the history remained a narrative of the security organization of the Turkish race. The essence remained the same whether it appeared as janissary or police officer (Emniyet Genel Mudurlugu, 1973; Toksoz, 1993). The Turkish police was prepared for the protection of the nation in the speeches of its chiefs and its journals as well. In the Polis journal in 1965, it was said that "we find the criteria we look for in the ideal police officer in our blood and racial character" (Sarioglu as cited in Berksoy, 2009, p. 107).

Throughout the late 1960s and 1970s, the military continued its attempts at associating with the police. The dissemination of the national security doctrine throughout the society and the state apparatus and influences on the personnel of the police were the main techniques of interessement by the military. The overall lack of disloyalty towards the military by the police indicates that interessement achieved enrollment in ANT terms. Below, we will look at how the 1980 coup affected the police department by expanding its role in the society and opening up the way for greater visibility in the Turkish polity.

\subsection{Police during 1980s: Purge, Discipline and Foster}

The 1980 coup d'etat was an important turning point for the police organization. This was so not simply because repressive police tactics were reinvigorated with greater eagerness after the coup. The army, officially in power until 1983 , was adamant to redress what it saw as the insufficiency of the police organization. This detection of insufficiency was made through not only an external observation but in a direct relationship with the police organization. The second article of the Martial Law Act (Law 
No. 1402, enacted in 1971) gave the army the authority to command "law enforcement organization as a whole" in places where martial law was declared. Note that this was more extensive than a state of emergency as it historically existed in the Western legal tradition. As Agamben (2005, p. 26) reminds, in modern states of emergency powers of the civilian authority were delegated to the armed forces for the preservation of civilian order. The martial law in the Turkish case went beyond this in that it delegated to the military the internal security organization itself, not only its civilian powers. This happened in thirteen cities following a pogrom in 1978 and then extended to other cities as the situation worsened (Ahmad, 2003, p. 144). While commanding the police, army officers developed a capability to know and direct it and acquired a better picture of the failures of the organization.

Prime among the military's concerns was the politicization of police officers into rightist and leftist associations, and their refusal to work with or get commands from individuals from the rival political group. The military was also worried about the lack of resources such as uniforms, vehicles, technical equipment; and lack of training (Bölügiray, 2001). Besides memoirs of the commanders, the concerns of the junta can be also read from a book published by the General Secretariat of the National Security Council (General Secretariat of the National Security Council, 1982). ${ }^{81}$ In a speech made on the first anniversary of military intervention, Chief of General Staff Kenan Evren took stock of the accomplishments and challenges of the coup so far. He also delved into the issue of political polarization and its effect on the bureaucracy. Polarization in the society was taken as a consequence of the double strategy employed by the "destructive factors"

\footnotetext{
${ }^{81}$ This book was prepared for explaining and justifying the 1980 coup to domestic and international audiences and with separate Turkish and English editions available.
} 
or rather the subversive elements in the country (p. 346). The "horror and fear" aspect of the double strategy aimed to terrorize the population, endangering public order and producing enmity through massacres, illegal strikes and demonstrations. The "penetration" aspect included penetration of political and social organizations and ultimately taking over the state administration. General Evren argued that the police was penetrated through police associations Pol-Der and Pol-Bir, leaning to the left and right respectively (p. 347). This sort of an approach to the problem implied that the subjects of polarization and division in the civil society could not be rehabilitated but only excluded. This logic formed the basis of the purges within bureaucracy and applied to all public servants including the police officers.

Yet the army did not simply see the police as a neglected and penetrated part of the state. It also saw it as an important arm of the administration that had to be put in proper shape. Similar to previous shifts in power the military implemented a series of measures to dissociate the police from previous governments and the penetration of insurgent forces. A new uniform was adopted for the police officers. The September 12 junta thought that the police was lacking not only in terms of its technical capacity but also in terms of its relations with the public and social status in society. To overcome these problems, several measures were taken. Public funded housing projects for police officers were accelerated to improve the economic situation of the officers (Bölügiray, 1991). This would also strengthen the loyalty of officers towards the state by making them less dependent on the local population for favors ${ }^{82}$ and isolating them from the rest of the population (cf. Gourisse, 2009). The police organization had to be disciplined and

\footnotetext{
${ }^{82}$ These favors included a free lunch or fuel for the patrol car. In time, these relations could lead to a dependence on the local population and hence give rise to conflicts of interest.
} 
fostered. A law on reorganization and modernization of the GDS (so-called EM-REMO law) was enacted after the coup. This new legislation expanded the budget of the police, adopted criteria for promotions modeled on the army, and helped increase the number of law enforcement personnel drastically while the average training and education period for officers was increased (Berksoy, 2007, pp. 81-82).

The practices of interessement of the police by the military are also apparent in the disciplinary measures. One of the first acts of the generals was to get control of the police via the Martial Law clause. The junta replaced the civilian head of the DGS by a lieutenant general (Milliyet, 1980a). With this, the generals aimed to administer the police with strict discipline as they did for the army. Police officers received courses on "salutation, respect and discipline" (Milliyet, 1980c). A new balance of punishment and reward was established in the organization. Penalties were more strictly implemented while officers were enticed to cooperate with cash rewards. Between September 1980 and April 1982, 8543 officers were given various disciplinary punishments, while 2341 officers were awarded due to contributions to the service. Within sixteen months of the coup, 2249 officers were suspended, 496 arrested, and 1227 discharged from the service. Many police officers were "forcibly retired" in 1982 due to their political activities. By 1983, the number of discharged reached to 3059 (Acar, 2004; Milliyet, 1982a, 1982b, 1983). Purges were made on the basis of a 1982 amendment to the Martial Law Act which paved the way for the implementation of martial law commanders' orders relating to the dismissal of civil servants (Alexander, Brenner, \& Krause, 2008, p. 23). Given that the number of police personnel was around 50 thousand in 1980 (Sahiner, 2008), the number of penalized personnel was close to $10 \%$ of the police force. 
Further measures were taken to discipline the organization. The police officer associations were already closed down. The Public Servants Law was amended in 1982 to limit political participation for all public servants including police officers. An additional article sought to enroll the police administrators to the objectives of the junta by giving those officers who received army's National Security Academy certificate priority over others in promotions (Law No. 657 on Public Servants, Art. 7 and Add. Art. 21). In 1983, several subparagraphs were added to the Security Organization Discipline Regulations to prohibit use of police radio to criticize supervisors, incitement to disobedience, use of personal guns in duty, and torture (see text at Adalet Bakanligi, n.d.b). Besides these measures targeting the police force, the regulations on entrance to the Police Academy were also amended to exclude individuals or individuals with "undesirable" parents, that is, parents involved in pre-1980 political activity (Milliyet, 1985).

These disciplinary and organizational measures were taken by the military to "dissociate and extract" (Callon, 1986) the police from unwanted societal and political influences. The military regime attempted to construct an actor-network of security through the deployment of punishments and rewards, public housing, infrastructural improvements and so on. Strengthening and sustaining the discipline in the police department remained as the priorities from the mid-1980s on. Purging the police became less prevalent as this was already accomplished and also the courts began overturning suspensions of civil servants. ${ }^{83}$ The priority of the government was now fostering the

\footnotetext{
${ }^{83}$ No conclusive data is available concerning how many suspended police officials were admitted back to the police profession.
} 
police department with addition of new personnel, granting of new powers, and provision of the facilities and tools for policing.

\subsection{Anti-Torture Strategies in the 1990s}

In the late 1980s and 1990s, the two factors that were most influential on police practices were the increase in political violence ${ }^{84}$ and the limited expansion in and practice of civil and political rights in the country. Increasing political violence by the ethnic secessionist PKK and radical left (mainly the armed group Dev-Sol) prepared the ground for some in the state elite and the police to propound a tougher stance towards terrorism. The end of the Cold War, on the other hand, created an anxiety in the political class as to the future of the nation in the New World Order (Muftuler-Bac, 1996). Throughout the Cold War, Ankara identified itself with the West and NATO, and saw its basic mission in international community as being a bulwark against Soviet expansion and defense of NATO's southern flank. As Muftuler-Bac argues, with the dissolution of the Soviet Union, it was thought that Turkey has lost its mission. The Iraq War and the de facto autonomy gained by the Kurds in northern Iraq, added to the anxieties that maps were being redrawn in the Middle East and Turkey could be dismembered. The new survival strategy was being useful to and renewing ties to the Western world and in particular deepening relations with the European Community. The problem was that, the

\footnotetext{
${ }^{84}$ The ethnic secessionist PKK targeted public personnel at all levels from schoolteachers to soldiers, and concentrated its activity in the Kurdish populated rural areas as a matter of their military strategy of controlling native space. Armed leftist groups' selection of bases (urban vs. rural areas) depended on their military strategy, but the most significant organization Dev-Sol (Devrimci Sol or Revolutionary Left) was active mainly in bigger cities. Unlike the PKK, which was rather indiscriminate in its attacks, the latter targeted specific individuals within the state bureaucracy whom they claimed were responsible for "attacks on the people." Assassinations of several police chiefs were claimed by Dev-Sol, which stated that the persons in question were "tried" and condemned to death due to their role in torture and ill treatment. In 1992, fifty four officials were killed by Dev-Sol (Human Rights Watch, 1993, p. 4).
} 
Soviet Union threat was gone, and there were fewer reasons to shield a Cold War ally, Turkey, from human rights criticism.

Thus, Turkey's strategy of survival in the post-Cold War era had to respond to two conflicting demands: human rights and a push for greater "decisiveness" against terrorism in the country (Bozarslan, 2001). This gave rise to a confusing picture. Initiatives for improving human rights coincided with the gravest counter-terrorist measures. For instance, the population suffered most from political violence in the early 1990s, which was also the period when there was a post of "Ministry Responsible for Human Rights" in the government. Another example was that between 1991 and 1994, Kurdish opposition gained political representation in the national assembly. Kurds have served in public and political offices before, but this was the first time when Kurdish identity was overtly expressed in the national assembly. Yet again, these were the years when low-intensity conflict raged unabated in the southeastern part of the country (Bruinessen, 1996).

In the late 1980s and 1990s the influence of the national security doctrine was still apparent in the state apparatus in general and the police in particular. The textbooks used in police education were ambivalent towards human rights principles, the police supervisors and the judiciary were reluctant to prosecute practices of torture and ill treatment and police was still seen not primarily as a law-enforcement agency but an organization that fought against internal threats. Let me expand on these points in turn.

A textbook (Safak, 1991) used at the Police Academy advocated the use of polygraph and made a passing reference to narco-analysis as a useful method for uncovering the truth (Safak, 1991, p. 158). While polygraph or lie detector is less 
controversial, the use of narco-analysis violates suspects' rights. It involves the administration of the so-called "truth drugs" to suspects arguably to prevent them from lying and reduce their resistance to interrogation (Calkins, 2010). As such the reliability of narco-analysis is not evident and it clearly breaches free will principle in statement taking (Keller, 2005).

A lenient attitude towards violations of suspect's rights was maintained in the police. Police chiefs were adamant to deal with officer wrongdoings in an opaque way, and misconduct was merely verbally reprimanded, if ever. Indeed, until 1999, permission from an official board was required for trying public officials, and governors who chaired these boards were reluctant to give permission for accusations of human rights violations. In cases where police misconduct was handled by the criminal justice system, the outcome was not much different. Prosecutors and judges saw the police officers as officials working for the good of the state and nation, and chose to minimize their offenses or give lightest possible sentences (Cerrah, 2008; see interviews with members of judiciary in Sancar \& Atilgan, 2009, pp. 122-128).

The police understood itself, and was promoted increasingly as a domestic army fighting against internal enemies, namely terrorists and traitors (Berksoy, 2007; Bora, 1994/2006). A case in point was the eventful May Day demonstration in Istanbul in 1989. In 1980, the junta prohibited to conduct any political demonstrations in the Taksim Square. In 1988, several trade union members attempted to make a demonstration in the historical square in Istanbul, which was the scene of a massacre in 1977. Eighty-one trade unionists were apprehended. Next year in 1989, several groups attempted to make a demonstration in the same square. Police again prevented the crowd and one 
demonstrator was killed (Mavioglu \& Sanyer, 2007). The Istanbul police chief explained that objective of the police was "to prevent hoisting of the red flag with hammer and sickle and the Kurdish flag [to the flag posts] in Taksim square" (Isleyen, 1989, p. 13). Hence, the police transcended its routine duties and powers of public order and sought to reaffirm state sovereignty on Taksim square against subversives and separatists. This identification with the survival of nationhood was also rehearsed in the funerals of police officers. Much like the army, the losses of the police organization were projected as martyrs and the pursuit of criminals that killed police officers regarded as operations of revenge (Bora, 2001).

If the police were so immersed in human rights violations, how did it come to participate in the anti-policy of torture? The constructivist boomerang (Keck \& Sikkink, 1998) and spiral models (Risse, Ropp, \& Sikkink, 1999) mentioned in Chapter 1 would describe this development in terms of the pressures of the international actors on the state. These pressures would create incentives for the state or convince elites it to behave according to the human rights norms. Although I agree that these pressures were an important part of the story, we need to analyze how the actions of the human rights advocates produced their effects. By bringing together the analytics of anti-torture strategies and theoretical tools introduced in this chapter, I seek to provide a different account of the participation of the police in anti-torture efforts.

This account differs from the constructivist account in several ways. First, I do not assume that convincing or luring the government or the elites are sufficient for the implementation of human rights reforms. There have been instances of vehement opposition to police reform in the country. A case in point was seen when Criminal 
Proceedings Procedure Law (popularly known as CMUK) was amended in 1992 to decrease the maximum period of detention and improve the practice of right to counsel while under custody. The reforms were modest, in that they managed to decrease the period of detention to 24 hours for individual crimes and to eight days for crimes committed by more than three persons. While eight days was well above the four day European norm, these articles did not apply to charges relating to terrorism broadly defined, or in places where emergency rule was in order (Milliyet, 1992a). Adoption of new legislation in the parliament coincided with the killing of four police officers and the funeral ceremony in Istanbul became the opportunity for the police officers to show their reaction to the new laws. The funeral was attended by both police managers and officers in large numbers. Among the public figures was the Director-General of Security, chief of Istanbul police, and a former Minister of Justice. Chief of Istanbul police made a bitter speech and loathed human rights advocates for protecting the terrorists. The officers, on the other hand, were joined by the civilians in shouting slogans such as "no to CMUK", "human rights, the enemy of police", etc (Milliyet, 1992b).

As the opposition of the police to human rights reforms makes clear, the prospects of reforms would be improved if human rights advocates sought to enroll not only the government but the police as well. The schemes that did not do that were less likely to be taken up and translated by other actors. Second, unlike the boomerang and spiral models, I do not treat the practices of different advocacy networks as essentially identical. The constructivist thesis treats the actions of the human rights networks in a cumulative way: if sufficient numbers of actions accumulate over time they lead to a change in the political will of the government. The analytics of strategies introduced in Chapter 2 
allows me to see the differences among the programs advocacy networks recommend for eradicating torture. The nature of these programs, in turn, is relevant for the success of their actor-networks. It is seen that schemes within the accusatory strategy such as disciplinary measures and punishment have less chances of being picked up as opposed to schemes of the preventive strategy that advocate involving the police and improvement of its capacity.

By focusing on five documents on torture and ill treatment in Turkey published between 1986 and 1994, I will try to substantiate the points made above. I place three UN reports (UN Commission on Human Rights, 1986, 1989a, 1989b) in the category of accusatory strategy and two reports by the CPT (1990a; 1990b) in the category of preventive strategy. The UN reports were written by Dutch human rights expert Peter Kooijmans, the special rapporteur for torture. The position of the special rapporteur was established in 1985 by a resolution of the UN Commission on Human Rights and given duties such as undertaking fact-finding visits to countries and submitting annual reports on its activities to the Commission on Human Rights. In his 1986 report to the Commission on Human Rights, Kooijmans set forth certain principles guiding his work and later visit to Turkey. The special rapporteur argued that torture was the outcome of "situations in which human beings find themselves in the absolute power of other human beings" (UN Commission on Human Rights, 1986, §8) and since these situations would always occur, the struggle against torture should never end. He also considered that the abolition of torture as a judicial practice was the result of a "moral awakening" and the ongoing practice of torture meant that "this moral awakening has not yet had tangible results for everybody" (§147). The international community and the states should 
struggle against torture by guiding the public opinion, prohibiting torture and punishing those who are responsible for the acts of torture (\$40, 44-45). Kooijmans emphasized the punishment aspect of the struggle against torture by calling on the states to take measures to consider torture as an international crime and cooperate for the punishment of this crime $(\$ 50-51)$.

This emphasis on the punishment was sustained in his recommendations proposed following a visit to Turkey in 1988 . Kooijmans made six recommendations to the Turkish government: abolition of incommunicado detention; examination of victims of torture by independent, qualified and experienced medical experts; investigation of complaints by an independent body; severe penalties for torture; exclusion of evidence obtained through torture; inclusion of the respect for human rights in police training (UN Commission on Human Rights, 1989b, §233). As understood from his previous report (UN Commission on Human Rights, 1986, §106), Kooijmans was concerned about the incommunicado detention not because it constituted a form of torture but because it created conditions for torture by cutting off the prisoner from the outside world. The secrecy that surrounded the detention process meant that there were no eyewitnesses of torture thereby making it possible for the torturers to evade accountability. The recommendations regarding medical experts and independent investigations are also proposed mainly to make the punishment of torturers possible. Medical expertise is necessary to produce evidence for torture while independent investigation replaces the internal or judicial supervision of the police. The recommendation on the exclusion of evidence is not a preventive measure in the strict sense since it pertains to cases where torture has already taken place. Only the last two recommendations can be seen as purely preventive measure against torture. The 
most important concern for special rapporteur for torture, then, was impunity. The main reason, it seems, for the perpetuation of torture in the country is that torture is difficult to prove in court, torturers are not being investigated and the penalties are lenient. Kooijmans's basic argument for the punishment and prevention of torture was that it was morally indefensible and unbecoming of human dignity. Through his reports, he attempted to redefine the identity of the police officers as concerned human beings with a moral worldview and did not take into consideration or seek to redefine their professional interests in fighting crime. There were no guarantees that the police would be able to do its work better when they accepted the roles Kooijmans suggested for them. The special rapporteur attempted to translate his scheme into practice by saying to the government and the police that they should follow him because it was the correct thing to do from a human rights perspective. Although what Kooijmans said was right, it proved to be unrealistic for the government and the police.

The failure of translation can be observed in the communications between the Turkish government and the special rapporteur (UN Commission on Human Rights, 1989a, \$257-258). Regarding the recommendation for the abolition of incommunicado detention, the government indicated that detained persons already had the right to access a lawyer and they could use it as long as it was not abused and was not harmful to the investigation. The government effectively rejected other recommendations as well by claiming that medical experts giving testimonies on torture were already competent, that an independent investigative body was not possible due to Constitutional limitations, that penalty for torture was already severe and that exclusion of evidence through torture can be accomplished through a separate legal case. The only accepted recommendation was 
the training of police officers, but this seems to be the outcome of developments independent from the special rapporteur's recommendations.

Let us compare this accusatory strategy with the reports of the Council of Europe's CPT which maintained a preventive strategy against torture. It should be noted at the outset that unlike the UN reports above, the reports discussed here were not made public until the government authorized their publication in 2007. The first difference between the two strategies is apparent in the preface of the CPT report where the Committee defines itself "as a mechanism designed to prevent torture and inhuman or degrading treatment or punishment from occurring" (CPT, 1990a, p. 8). The cooperative approach of the CPT was also apparent in its claim that torture was not only against civilized conduct but also ultimately harmful to the national authorities in general. Such a problematization of practices of torture was not found in the UN reports mentioned above. Unlike the "moral awakening" thesis of UN's Kooijmans, CPT considered that torture in Turkey can be discerned at the socio-economic and legal levels (CPT, 1990a, pp. 19-20). The Committee argued that political polarization, widespread political violence, and social acceptance of violence in the schools and the family provided the socio-economic basis of torture and ill treatment while several legal restrictions on human rights formed the legal aspect. In terms of the recommendations, there were similarities between the measures proposed by the CPT and the special rapporteur. Reduction of the maximum period of detention, abolition of incommunicado detention, independent medical examination of victims of torture and proper investigation of allegations were recommended by the Committee (pp. 37-40). However, there was a significant difference of emphasis. The Committee indicated that "attacking the root of 
the problem involves not so much changing the laws as changing attitudes and behavior" (p. 37). The CPT pointed out that legal and technical safeguards were not sufficient for preventing torture. There was a need for not only the education of officers to respect human rights but also professional training of officers. This would show to the officers that "torture and other forms of ill-treatment are grossly ineffective means of combating crime" and "interrogation techniques which respect human rights are likely to yield better results from a security standpoint" (p. 41). Therefore the Committee was not saying to the police officers "I want it, why don't you?" (Latour, 1987, p. 111). ${ }^{85}$ The Committee was saying that "if you make a detour and go from the route that we suggest then you can attain your objectives more efficiently." The Committee was framing torture not basically as a problem of impunity but an issue of respecting human rights while investigating crime. While the special rapporteur suggested that the police officers become moral subjects, the Committee suggested that they become better and more efficient police officers while being moral subjects. A further move of interessement of the police by the CPT was the identification of the Police Academy as a distinct actor in the network. As we can see from the recommendations of both strategies, medical experts, judges, and lawyers were mentioned as actors in the network. The Police Academy, however, was mentioned only by the CPT. The Committee made a specific recommendation to the government to "give high priority to the development of the Academy's activities" (p. 41). It appears that the Police Academy was important for the CPT because it had an essential role in the education and training of police officers.

\footnotetext{
${ }^{85}$ Bruno Latour uses this phrase to describe a mode of translation where contenders seek to implement their projects by having other actors follow them. Latour points out that such displacement is very rare and happens only when the usual way of other actors is cut off.
} 
The responses of the Turkish government and the police to the recommendations of the CPT suggest that interessement has been successful and enrolment has been achieved to some extent. ${ }^{86}$ Let me give several examples. In line with the CPT recommendations, GDS drew up a code of practice for the conduct of interrogations (CPT, 1990b, p. 5), two textbooks on human rights were adopted for use in the Police Academy, the Ministry of Justice was requested to give lectures to the police officers on the conduct of investigations (CPT, 1990b, p. 44), 20 security officers were sent for training to the Council of Europe member countries (CPT, 1992. p. 8). Certainly these acts were tiny steps when considered within the context of the gravity of the problem of torture. The persistence of torture in the country and CPT's frustration can be read from the two public statements they made in 1992 and 1996 (Gemalmaz, 1999). Nevertheless, when considered in the long term it is seen that CPT's preventive strategy has been taken up by others. This can be seen in the 1995 study by experts Sulhi Dönmezer and Feridun Yenisey which has been extensively discussed in Chapter 3. We have seen that these experts made suggestions to enhance the crime investigation capacity of the police as a means to prevent human rights violations. In addition to this, at least one police official interviewed for this dissertation indicated that the recommendations of the CPT have been useful in overcoming problems of torture in Turkey (personal communication, anonymous police official, June 29, 2007).

\footnotetext{
${ }^{86}$ Since these communications between the Turkish authorities and the CPT were not public (and only published in 2007) there is reason to believe that they were not simply made to give the appearance of cooperation.
} 


\subsection{The Vernacular Discourse of the Police}

In the previous section we surveyed the problematization of the torture from the point of view of the contenders, the special rapporteur on torture and the CPT. As indicated in the introduction to this chapter, in order to understand the participation of the police in the anti-policy of torture, we need to complement this account with the perspective of the police. I seek to accomplish this in two steps. First, I identify a discourse circulating in the police that seeks to rationalize the reform of the police with reference to some external conditions. Second, I try to link the participation of the police in the anti-policy of torture to the competitive relation between the police and the military in the next and last section of this chapter.

In the mid-1990s, it is possible to detect the emergence of a vernacular discourse of police reform. This new discourse was most often produced by state actors and their allies. In this category, I include bureaucrats, high and medium level police managers, and occasionally politicians.

This vernacular discourse was not exactly a discourse of contrition. Especially in the first years of its emergence, it is not possible to find a systematic criticism of past human rights violations. It was not a precise acknowledgement of criticisms advanced by human rights organizations and liberal intellectuals. It was rather a discourse of selfrenewal, a move which was necessitated by developments beyond the police. The idea was that the police should renew and update themselves according to the changing global circumstances. This was necessary not only to avoid being redundant but also to prevent external actors to design the police. In some ways, this was similar to the discourse deployed by European political elites to justify neo-liberal economic policies. As Hay 
and Rosamond (Hay \& Rosamond, 2002) argue, policy makers in Europe constructed globalization as a necessity, a material constraint on the nation-states. The neo-liberal policies were not "caused" by globalization, but political elites creatively and strategically deployed this discourse to sell the policies to their constituencies. The authors of the vernacular discourse engaged in a similar practice by invoking globalization as justification for reform. Here globalization was understood as an encompassing process that generated vulnerabilities in political, economic and social spheres of a country to the developments beyond the borders. Due to the process of globalization, human rights were no longer seen as domestic issues and it was increasingly being accepted that external actors can intervene in human rights problems. Concurrently, it created opportunities. If a nation could keep pace with the developments, it could improve its position in the global distribution of power (e.g. Citir, 2003).

The police reform discourse, deserves the label vernacular due to several reasons. Rather than engaging with civil society or national publics, this language mostly addresses the police community itself. It is a dialogue among peers. It includes certain experts who are well intentioned or police-friendly while excluding others as being ill intentioned or, worse, pro-terrorist. A case in point is a Police/Public Relations conference organized in 1995 by the Police Academy. The conference coincided with the so-called Gazi Troubles in Istanbul where a group of armed men sprayed bullets on a café in the Gazi community of Istanbul. The community was known for its low-income and minority Alevi ${ }^{87}$ population and a local religious notable was killed in the event. This led

\footnotetext{
${ }^{87}$ Alevis are a Muslim minority group living in Turkey. They differentiate themselves from the dominant Sunni sect and practice and interpret Islam differently. The roots of differentiation go back to the $7^{\text {th }}$ century.
} 
to demonstrations in the neighborhood and the intervention of the police left 19 people dead. To come back to the conference, one of the participants was Professor Metin Kazanci of Ankara University. Kazanci, choosing his words very carefully, expressed his disapproval of the police conduct in Gazi Troubles in the conference. ${ }^{88} \mathrm{He}$ said "it is not possible to approve police actions," (Kazanci, 1995, p. 55) while demonstrating considerable effort to prove that he was an insider to the police community, and not a police basher. He went on "this [event] only saddens me, saddens me a lot, and I'm a son of a police officer. My father was a chief police officer.... I never lost my connection with the police and was an instructor at the Police Academy for 12 or 13 years" (Kazanci, 1995, p. 55).

This label of vernacular discourse is also used to capture the anxiety in introducing a sort of reform program to the police organization. Reform programs have been controversial mainly because they have usually originated from outside the police ranks. The scorning external actor that called attention to flaws could be NGOs, the media or any other critic. That is to say, they were actors that were not seen as necessarily identifying with national interests or state survival. Reform was often understood as an initiative to enfeeble the police organization by allocating some of its powers to judicial police, reducing police powers, instituting greater accountability and regulation. Therefore, the dilemma was how to transform police identities that were shaped for many years by a far-right agenda that argued against any "concession" to human rights criticism.

\footnotetext{
${ }^{88}$ In total, 27 papers were presented in the conference, of which 13 read by speakers from official institutions. This included two from the Police Academy, ten police bureaucrats, and one official from the Ministry of Justice. Other presenters included professors who lectured at the Police Academy or trained police officers (Azak \& Terzioglu, 1995).
} 
The vernacular language of police reform sought to accomplish this task by redefining police duties. The respect and allegiance to the state and the consciousness to serve its interests instilled in the police officers for so many years became an argument to divert their agency towards more democratic practices. While human rights terminology is utilized and referenced, human rights and freedoms are not exactly seen as foundational values. Human rights norms becomes part of the conditions of repowering state authority by shielding it from international attacks on its prestige and national interests by human rights groups or those using human rights for their own ends. An academy instructor wrote that

it is no coincidence that there is a Greek ${ }^{89}$ citizen in every international human rights committee concerned with Turkey. Greece is abusing human rights... as a tool of pressure over Turkey.... Even if Turkey is not admitted to the EU, it has to take more serious steps in human rights issues not to risk becoming a Third World country in the globalization process (Ozcan, 2000, p. 90).

This instructor articulated the widespread notion that human rights activism against Turkey was indeed a conspiracy to weaken the country. We have seen in Chapter 2 that human rights activists were even persecuted on charges of inciting separatism in a human rights report. ${ }^{90}$ Despite the negative connotations of human rights for police officers they came to see this notion as a resource in world politics, compliance with

\footnotetext{
${ }^{89}$ This is a reference to the historical rivalry between Greece and Turkey. Greeks gained their independence from Ottomans, and Turks fought against Greeks in the national "War of Independence." The relations between Greece and Turkey are still problematical today.

${ }^{90}$ This is in some ways similar to the recent Israeli policy of limiting the activity of human rights defenders. The Netanyahu government, took a posture against human rights organizations in Israel with some ministers calling the groups "fifth column for terrorists" (Horowitz \& Weiss, 2009, p. 4) while Ministry of Defense officials "depicted the NGOs as traitors" when they interrogated the Israeli Army's operations in Gaza (Euro-Mediterranean Human Rights Network, 2010, p. 40).
} 
which was necessary to further state interests. Human rights should be observed because this will bring more advantages to the state and eventually the police organization. This paradoxical situation may be explained with reference to the fact that for many years, human rights came to the attention of the police mostly through foreign channels like human rights organizations or UN and CPT. Now; the problem was to "internalize" it. As a police manager put it, the police "should themselves advocate an issue as important as human rights and not let it be defended by others. In my opinion, abandoning the defense of human rights to some associations is the biggest MISTAKE" (Dundar, 1997, p. 67)

The difficulty of justifying reform can also be detected in the answers to the question of why the police organization needs to change and renew itself. Mehmet Ağar, the hardliner Director-General of Security, pointed out in a conference in 1995 that the police organization is trying hard to adapt "to a structure mirroring the development in society" (Agar, 1995, p. 3). According to him, the police organization was one of the most important institutions of society, and one of the institutions that best reflect Turkish characteristics in terms of social, religious and other aspects. Rapprochement with the EU and changes in society were putting a strain on the police. Thus the reasoning went: the society was changing, its expectations being transformed, so should the police. As Yuksel, the then chief of police put it, it was essential to "keep in step" with the society to prevent its alienation. He wrote in 1996 that police has to change because the environment it is operating in was changing.

Social development and change is gaining new dimensions, the perspective on the police -who has been the symbol of authority-, has changed and new expectations from the police have emerged.... Social, cultural and economic 
developments... have led to new concepts and understandings in police and security [as a result of] new concepts in state, law and human rights.... The time has come to make an evaluation regarding new police functions and especially restructuring it along with the concepts of right, law, human, crime and criminal.... To further develop the police organization an evaluation has to be made taking into consideration the expectations of the public from the police (Yuksel, 1996, p. 4).

The head of the training department of the police also emphasized the currency of human rights. "Globalization is forcing change. In our land, we have a young and dynamic societal structure that is interested in exercising rights and freedoms more than ever" (Isik, 1999, p. 101).

The organic relationship between the police and the society (or the people) was frequently repeated in the vernacular discourse and used to justify changes in police organization. "Police/people relations" (polis-halk ilişkileri) existed as a sensitive interface between officers and the community. The latter was seen as an important source of information in fighting crime and a noteworthy source of contributions in kind and in cash. These were valuable assets for an organization when it had problems in intelligence gathering or finding the money for purchasing new equipment, making renovations to police stations, or even buying fuel for patrol cars. Therefore, police service should satisfy the public. Yet, as the then chief of Istanbul police Necdet Menzir, warned, "the dosage of public participation has to be calculated carefully" (Menzir, 1995). Neither the public should become an unwelcome intruder in police business nor should the police shift its responsibilities to the public. 
Relations with the public became the contemporary criteria for judging modern policing. The latter was appraised "not with the proportion of crimes solved but the quality of the relationship between the police and the people, the confidence inspired to the public and... public participation in preventing crime" (Emniyet Genel Mudurlugu, 1995, p. v). Assistance to police from the public "provides legitimation for all practices including use of force" (Aydin, 1998, p. 120). The police should adhere to human rights, to satisfy the public. A police educator wrote:

Arbitrary behavior of police may reduce public confidence in the state. It is only natural that victims [of abuse] resort to use of force against the police forces to protect their rights and freedoms. In addition, this could lead to chaos, conflict, and even worse consequences. In this environment, economic and political pressures on the state will accelerate, sources of income (such as tourism and foreign investments) will be hampered..., most important of all, the prestige of the state will erode. (Ozkavak, 2003, pp. 60-61)

Thus, a local practice by police officers would have national and international ramifications. This reasoning was taken a few steps further by some police managers and officers were told that their role in realpolitik was not limited to the negative act of refraining from rights abuses. They could contribute to the advancement of national interests by negotiating human rights demands with the EU. They could even lift the hurdles on Turkey's accession by adopting more human rights oriented practices. "Police stations with no torture would be the contribution of the police to the Turkish Foreign Policy" (Ozcan, 2000, p. 94). Hence, the ethic that was offered to the police officers in 
the vernacular discourse was being a participant in high politics by orienting professional conduct towards human rights.

This ethic required a public posture by the officer. The police organization was disparaged for so many years by so many people. Lack of communication on the part of the police was a big factor in the "misunderstandings" to which the police have been subjected. So the new police officer should be the "officers of the information age" (Altintas, 2003, p. 16). Officers should accept that they need to make themselves known (Menzir, 1995). Indeed, human rights abuses are perpetrated not by the police but by the state. Police pays the bill because it is not able to "defend himself" (Ozdemir, 2001, p. 41). It was not enough simply to comply with the requirements of EU membership process. The officer of the information age should be able to market himself and tell about the success of the organization. Otherwise, police cannot get the place it deserves (Kaplan, 2006).

Thus, police discourse was reconfigured mainly with reference to the process of globalization which was modifying the national interests and expectations of the public. The police was already familiar with both of these concepts. Practices in line with human rights were promoted with reference to public support by arguing that lack of it would endanger professional interests. The second point of national interest was also significant for police identity. The police was asked to comply with human rights to serve the national interest. What the constructivist theories predicted was an opening of nationstate identities to embrace global and European values, and socialization of the nation into universal norms. What the vernacular discourse suggests however did not exactly conform to this prediction. The universal vocabulary of human rights was adopted, and 
reflected in state practices. Yet, the national identity and suspicion towards European recommendations and human rights activism endured. Perhaps this was an effect of the national security doctrine that for so many years defined the framework of reflection and practice for the police. In this regard, it becomes necessary to look into the relations between the police and the military. How did the relations between these actors of the field of security evolve and what are the implications of this relationship for the participation of the police in the anti-policy of torture?

\subsection{The Police and the Military}

The armed forces in Turkey and its gendarmerie force need to be taken into consideration to understand the power relations within which the police officers are shaped. Both the army and the police exercise social control over the society. As Didier Bigo points out, police and army operate on the same or overlapping terrains and are in competition for resources or for the production of truth about dynamics of social order and identification of threats to society (Bigo, 2008). However, while Bigo's argument on the emergent nexus of police/military relates to the contemporary transnationalization of security, the competition between the police and military in the Turkish case emanates from the military's long-standing guardian role (Cizre-Sakallioglu, 1997; Goldsmith, 2009), a role that included tutelage over the police. As seen above, since the 1960s, the armed forces have increased its role in political life of the nation while maintaining a "politically autonomous" position within the polity. The army defined itself as the ultimate protector of the political regime and integrity of the state, operating beyond the party-political and particular interests of other societal actors and therefore beyond reproach. Since the police was formally under the control of the government, the army 
viewed it with suspicion. The army was the real owner of the mission of protecting the regime. Cooperation with and instrumentation of the police was possible, but at the same time, it was a force to be checked and balanced.

In this section, I will show that until the 1990s, police officers have been shaped to perceive the army as their "elder brothers," more capable and potent than themselves for providing security. The military, as the self-appointed guardian of the regime, has tried to ensure that the police capabilities did not exceed that of the army. In the minds of the generals, the police department was not always reliable as it was in a closer and more intimate relationship with the civilian governments. In this process; the police and the army were at odds over the control of intelligence, weaponry, urban space. In the late 1990s, the police organization started to resist, disputing the tutelage of the army over itself. In the late 2000s, this challenge has begun to turn into surveillance over the military as the police was given a role in securing democratic political life from the encroachments of military officers. Arguably, it even replaced the military as the guardian of the political regime in the country. While the process in 1990s can be seen as the restoration of the self-confidence vis-à-vis the army, police operations against the army helped nurture self-image of the police as the beacon of democratization and civilian authority.

A starting point for understanding how police identity was shaped in relation to the image of the army is the police march. This march can still be heard today in ceremonies and anniversary celebrations of the police organization. ${ }^{91}$ The refrain of the police march summarizes position of the police as a domestic variant of the army: "Army

\footnotetext{
${ }^{91}$ The police department organized a contest to find a new police march. As of 2010, no suitable march was found for the department (Gunec, 2010).
} 
guards the borders, we guard the interior/ We are the POLICE, the symbol of law and the regime" (Wikisource, n.d.). Apart from the police march, the notion that police was a domestic army was popularized in the 1970s by a noted author, Ahmet Kabakli. Writing in 1975 in the daily Tercüman newspaper, Kabakli argued that police organizations have become domestic armies in all civilized countries of the world and chiefs of police have turned into commanders. Police should be modernized and be more like an army, from which he understood, to "have modern equipment, be powerful and respected... with increased competency, clout and eminence" (Kabakli, 1975, p. 7). This notion of domestic army not only encouraged hard-line policing against security threats, it also registered the lead position of the army. Note that there is no such reference to police in the army march. A sentinel army's practices of intervention into civil and political life were shown as qualities to be emulated by the police so that it could join the military in guarding the regime.

In times of civilian political order, institutional autonomy of the army and its professionalism was developed in a way to ensure that the gendarmerie was in a superior position vis-à-vis the police. In internal security, the police and the gendarmerie had identical duty and powers. Both were accountable to the Ministry of Interior in terms of their functions. The gendarmerie was concurrently a part of the military, which controlled the promotion and appointment files of the personnel. This resulted in a situation where the control of the Minister of Interior over the career path of individual gendarmerie officers remained nominal. The pay of the gendarmerie is also higher than that of the police officers, who arguably do the exact same job (Polat, 2007). Perhaps most important from an institutional point of view, the Gendarmerie Commander was included 
in the National Security Council (NSC) following the 1980 coup d'etat whereas the chief of police was only invited on an ad-hoc basis. As explained in Chapter 3, the NSC was, until very late, an important body that facilitated military intrusion into civilian politics. When the army took power, the subservient position of the police became more apparent. For instance an event after the 1960 coup confirms that the military viewed the police force and especially its intelligence department with suspicion. On the day of the takeover, the police intelligence department was locked and sealed only to be opened months later (Ozdemir, 2009, p. 44). Army officers subsequently examined the documents in the unit to see whether the army was spied on. Intelligence police was distributed to other posts throughout the country with non-intelligence duties. No similar event was registered after the 1980s coup, Ozdemir points out, as the police was rather cooperative with the military junta.

A nadir in the police/military relationship was experienced in the aftermath of the Susurluk scandal of 1996 . When the discrediting relationship between politicians, mafia and the police were burst into view in this traffic accident, the prime minister's office requested a report from the inspection council regarding the links between the underworld and the security establishment. In his report, Kutlu Savas, as head of the council, defined the state of affairs as "the replacement of national and patriotic considerations with personal interest" and pointed finger at the police, especially the Special Teams (Bese, 2006) while the gendarmerie was seen as only partially involved in this criminal nexus (Savas, 1997). As the military once again increased its tutelage on political life in 1997 citing threats to secularism, it sought to take under control the special operations teams. In this process, the police organization seemed to side with the 
civilian government against military encroachment. In terms of the field theory, this can be interpreted as a move by the military to expand its role in the field of security by assuming greater authority in the provision of security. The police reacted to this move by allying with the civilian government. It seems that the police developed an understanding that as the military increased its clout in the political field, it would also increase it in the security field. Therefore, reduction in the political role of the military could decrease its chances to fasten its hold on the security field.

Support for this point can be found in the vernacular discourse. Writing on Turkey's response to PKK, Durna and Hancerli (2007) argue that During the course of Turkey's fight against PKK terrorism, in which providing security and protecting the unity of state have become the primary concern, the police have been under the total control of the state [emphasis added] and responsive to the state identified problems.... In time, the public started to perceive the police as adversaries and as an instrument to deliver oppressive governmental policies... (Durna \& Hancerli, 2007, p. 335)

The remarks of the authors imply that the police have suffered from the counterterrorist measures by losing its legitimacy. It should also be noted that the authors argue that in the fight against terrorism, "the military took over the decision-making role" (Durna \& Hancerli, 2007, p. 332) and by implication, the police was within the orbit of the military.

While the military stepped up its efforts to influence civilian politics in 1997, a police intelligence report was prepared and presented to the Minister of Interior, providing information regarding suspicious activities of some high-ranking generals. The 
report talked about how a group of influential generals kept tabs on bureaucrats, business persons, journalists and politicians (Aksener \& Duzel, 2003). The generals appraised these persons in terms of their proximity to the military and their tendency to cooperate with it. When the existence of this report was learned by the military, the relations with the government further strained. Later, arguably as a reaction to souring of the civilmilitary relations, the Chief of General Staff has pressured the Anti-Terror and Special Teams Directorate to turn in heavy arms in its inventory (Gurel, 2010). This nadir was the starting point of police organization's self-assertion against the army. In this period, a group of Police Academy graduates put up an advert in some newspapers declaring that they are the "guardians of democracy" in reaction to the military's encroachment in politics (Zaman, 2011), which was justified on the basis of protection of secular character of the nation.

The rising tension between the police and army became especially apparent after the so-called Ergenekon case. This case comprises several ongoing police operations and legal cases that started in 2007, when police discovered a cache of grenades in a district of Istanbul thanks to a tip-off. The case, including its name, ${ }^{92}$ is highly controversial and is difficult to treat here in all its complexities. While some called it a "witch hunt" (Cagaptay, 2009) to silence secularist and nationalist opposition to the governing JDP, others saw an attempt to normalize Turkish polity and save it from the remnants of a Gladio-type network of journalists, opinion-leaders, army and police officers (Today's Zaman, 2008b). Suffice to say that unlike the Susurluk incident that implicated highprofile police officers, the Ergenekon case had focused mainly on the army officers and

\footnotetext{
${ }^{92}$ The name is controversial because Ergenekon also refers to a Turkish creation myth and some find it offensive that public prosecutors and the police refer a criminal network with this name.
} 
their allies. When the pictures of generals, albeit retired, being round up by police officers came together with allegations of planted evidence (Cumhuriyet, 2010) and claims of growing influence of Islamic groups within the police Intelligence Department (Jane's Islamic Affairs Analyst, 2009) it created a shocking impression for the guardians of the secular republic. It was now the police that had the upper hand and made sure that the army was not transgressing its legal boundaries. This identification with rule of law was crowned with the remarks of Prime Minister Erdogan in June 2009: "We, as a nation, are proud with our police. Police organization is an unshakeable assurance of democracy, legal system and the regime in general; virtually a guarantee of it" (Aydin, 2009; Today's Zaman, 2009).

The Ergenekon case had also significant implications for the struggle in the field of security. The case afforded the police to affirm its position in the definition of threats to the society. In the past, this was mainly in the hands of the military that imposed its own definition of national security through the National Security Council on other actors. In this scheme, religious fundamentalism, secessionism and radical left were defined as the main internal threats. In 2008 , however, the police seemed to challenge this definition by including "neo-nationalism" (ulusalcllik) in the list of threats to public order and AntiTerror Department of the police was tasked with handling it (Sardan, 2008). When it is considered that certain high-ranking members of the army were arguably adherents of this political outlook (Grigoriadis \& Ozer, 2010), the challenge of the police to the military's threat definition becomes more meaningful.

The recent status of police/military relations are understood in police discourse as proof that police organization has become, or on the way to becoming, a civilianized, 
community-friendly force for democracy within the Turkish state mechanism (Cerrah, 2005, p. 21; Elibol, 2008; Kaplan, 2008). Yet these concepts are not useful to describe the recent transformation of the police organization. In terms of being community-friendly or having cordial relations with the public, the police record is less than satisfactory. Police may have a favorable image in certain locales, or with broad sections of the population. However, its actions in May Day celebrations in 2007, or general attitude towards public demonstrations leads to a breakdown of its democratic image and requires some maintenance work in the media by pro-police pundits. Here one should note that, the military might at times be seen by some as a better alternative to the police. A case in point is that Gazi Troubles mentioned in this chapter. The spiraling out of control of the events had led the government to deploy soldiers to the region, which was mostly composed of male youth serving their obligatory military service. The crowds at the scene perceived the soldiery as "one of their own" and the tension subsided (Demirel, 2004, p. 355).

The civilian character of the police, implied by experts of "security sector governance" (Sariibrahimoglu, 2006) does not always resonate with its practices. The recent lobbying by the police organization and the National Intelligence Organization to have the legal permission to own heavier arms reduces the differences between the police and the military. Certainly, the latter has an unparalleled military force and inventory. However, the point is that the police department is keen to enhance its arsenal with lethal weapons, which erodes its claims to civility. The conclusion that police is more civilian because it is controlled by the government and not attached to the military overlooks the fact that militarism is a "set of ideas and structures that glorify practices and norms 
associated with militaries" (Chenoy as cited in Altinay, 2001, p. 4). Therefore, militarism is not confined to the barracks or praetorian politics but can be pursued as an ideology in public affairs (Ben-Eliezer, 1997), even without direct participation of armed actors. By extension, police, even when it is accountable to the public, can engage in militarized practices. Likewise not every act of the army can be branded as "militarized." Armies can also engage in civilian work such as social assistance programs or disaster relief. That is to say, it would be misleading to impose ready-made templates on security practices and conclude on the civilian character of a practice solely by looking at the identity of the actor. Rather, civilian vs. militarized character of a practice should be found out after the observation of concrete instances. In this vein, retreat of the military from security practices and its replacement by police does not always herald a civilian democratic polity.

\subsection{Conclusion}

In the previous chapters, we have seen that various anti-policies have been developed to improve human rights in general and to eradicate torture in particular. In the course of discussion of the strategies against human rights abuses, the figure of police identity has recurred as a domain to be intervened in. We have seen how British officers in colonial India thought about eradicating torture through building new police identities, through civilizing the Indian police officer. Similarly, shaping police identities was also suggested by Dönmezer and Yenisey in their comprehensive study on criminal justice system in Turkey. However, until this chapter we have not provided a systematic study of police identity. As argued in the introduction, government is an activity that acts upon the actions of others. Studies of governmentality emphasize that subjects are complicit in 
their own government. Writing on the EU peacebuilding operations in the Balkans to improve policing, Merlingen and Ostrauskaite (2006) argue that these missions do not promote human rights compliant police officers through "repression, prohibition and censorship" ( $\mathrm{p} .4)$ but rather through construction of normal practices and shaping police subjectivities in line with this normality.

This chapter has demonstrated that a parallel development to improve human rights has taken place in the Turkish police. The relevance of police identities was apparent in the accusatory and preventive strategies, which attempted to shape police identities in different ways. Yet, attempts to shape the police have also emerged from within police ranks. While disciplinary regulations have been used, an authentic police discourse also sought to shape police identities in line with changes in the political conditions. Our focus in this discourse made possible to see how the police practioners themselves came up with ideas of reform and in a sense responded to human rights strategies developed outside their bureaucracy.

We have also seen that professional rivalries between the military and the police have been a significant factor in the "self-renovation" (Durna \& Hancerli, 2007, p. 335) of the police. In this way I have shown that the internalization of human rights norms through socialization has not been the sole mechanism of the police participation in antitorture policy. The competition between the military and the police in the field of security and the experiences of the police in times of military encroachment in civilian politics have led the police to differentiate itself from the guardians of the Republic. This also implied that police was becoming aloof from national security doctrine which paved the way towards human rights violations in Turkey. 


\section{CHAPTER 5: TWINNING AS A MECHANISM OF INTERNATIONAL GOVERNMENT}

As pointed out in the previous pages, the problem of torture has been one of the most intractable issues between the European Union and the Turkish government and at least until the early 2000 s a formidable obstacle to the development of relations. As Ankara progressed towards membership first by confirming its candidacy status in 1999 and second by securing a date for the opening of accession negotiations in 2004, the eradication of torture and ill treatment of suspects by the members of the police assumed greater importance on the agenda. Despite the low prospects of eventual membership, Ankara was entering a process of "harmonization" of its legislation with that of the EU. The scale of transformation that a candidate country has to undergo is often expressed with reference to the more than 80,000 pages of legislation it must adopt in order to fulfill the conditions of membership. However, the problem of torture and ill treatment, covered by the $23^{\text {rd }}$ Chapter of accession negotiations (Judiciary and Fundamental Rights) falls under the pillar of Justice and Home Affairs, where Brussels has only a narrow mandate. To put it differently, the EU does not have a legal template to impose on the candidate countries in the area of policing and human rights. Nor does it have the human resources necessary to advise the candidates on how to improve human rights performance. The mandate of Brussels is limited to a paragraph of the Presidency Conclusions of the European Council in Copenhagen in 1993 known as the "Copenhagen Criteria."

These criteria include the "stability of institutions guaranteeing democracy, rule of law and human rights." Given the ambiguity of this formulation and the lack of capabilities, the EU has relied on other means to govern the conduct of candidate 
countries. In the area of human rights, one of these means was the informal delegation of human rights monitoring and normalization to the organs of the Council of Europe, especially the European Court of Human Rights. Another technology used to govern the conduct of candidate countries, introduced to EU repertoire in 1998, was twinning, that is, the secondment of EU member state officials to public administrations of the candidate countries to help the latter adapt to European norms. In the second chapter, I have analyzed various anti-torture efforts under the three broad headings of constitutional, accusatory and preventive strategies. The technology of twinning can be subsumed under the category of preventive strategies, as it is designed to operate as a rather low-key instrument focusing on overcoming "problems" through the provision of expertise, rather than the shaping of the ethos of government through shaming and instilling human rights values in the minds of the actors. As will be more apparent below, much like the logic of preventive strategy, twinning projects focused on administrative and bureaucratic capacities rather than on "political will." Twinning assumed that political will for reform was already secured through the candidacy process.

This chapter focuses on the use of institutional twinning as a technology to govern the EU applicant states' conduct. It begins with providing a brief history of this technology from its origin as a device for establishing transnational links between different peoples to its adoption by the EU. This is followed by an analysis of the expert discourse on what Turkey needs to do to meet EU conditions in the area of policing and human rights, and how this discourse conceptualizes the Turkish state and prepares the ground for twinning programs. After this, through a study of the project fiches and 
interviews, the chapter focuses on how the twinning projects on policing depoliticize the problem of torture and render it a technical problem.

Existing studies on twinning projects conceptualize it as a form of soft-regulation (Svensson, 2009) or institution-building (Tulmets, 2005b). Both of these descriptions capture many aspects of twinning projects. These projects may also be characterized as a technology of international government to emphasize its calculated character, its lineage of techniques of international government and administration and its affinity with the liberal thought. However, all of these labels remain at a high level of generality without giving much information about the content of institutional twinning projects implemented by the EU. In order to sharpen the diagnosis, and emphasize the distinctiveness of this technology, it can be understood as what I call "benchmarked harmonization." Twinning involves a complex mix of logics and techniques. The notion of benchmarked harmonization seeks to capture this multiplicity. Benchmarking is often understood as the practice of comparing an organization to "best performers" in the field to improve its way of doing things (Bruno, Jacquot, \& Mandin, 2006; Fougner, 2008). Yet it is not simply an act of comparison. It also involves the selection of the best performers, best practices and their procurement through a market-like mechanism. Benchmarking also involves the definition of clear targets. In institutional twinning, we see that the European Commission monitors the projects to ensure that they attain not only the desired outcomes of the specific project but also contribute towards the EU policy objectives.

The element of harmonization refers to the flexible transposition of European practices. The EU does not aim to clone European organizations and install them on the candidate country public administration. It provides an embedded expertise where the 
experts interact with "the locals" and take into consideration the national differences. In this way, harmonization aims to expand the commonalities between the EU and candidate countries in a dialogical process.

All aspects and details of the twinning projects analyzed here, on the other hand, may not be found in this diagnosis. This is a risk that comes with the schematization itself. Yet the schema includes the rather diagrammatic elements of twinning, that is, features that are applicable to other contexts as a template. To survey the formation of this diagram, the chapter now turns to the history of twinning.

\subsection{A History of Twinning}

The term twinning comprises various practices that aim to "produce proximity" (Clarke, 2009) between communities, municipalities, organizations and public administrations. Twinning programs can be distinguished into two basic variants as town twinning and institutional twinning. Town twinning was introduced in Europe after the Second World War to overcome feelings of enmity between peoples and demonstrate solidarity with communities that had been destroyed by the war. A similar scheme was initiated in the United States under the name of "sister cities." Although there is no consensus in the literature as to when these programs started, Weyreter (2003) argues that twinning originated in a goodwill visit by "leading citizens" of Bristol to Hannover in 1947. The German city had been subjected to heavy allied bombing during the war and was part of the British zone of occupation. Seeing the conditions in the city, Bristolians decided to provide food and clothing to the citizens of Hannover, the latter reciprocated by giving concerts in Bristol (Bristol City Council, n.d.). This visit popularized the idea that people-to-people interaction could be an effective way of improving understanding 
between different nations and contribute to the prevention of new wars on the continent. The practice of exchanging visits was maintained as one of the basic tenets of twinning as a means to observe the habitat of the counterpart and appreciate the conditions of its daily life.

This basic idea of mutual understanding rooted in interaction was also taken up by federalists in Europe, who proposed a project of European integration on the basis of municipal grassroots as opposed to the state-to-state relations (Ewen \& Hebbert, 2007). The Council of European Municipalities and Regions, founded in 1951, reflected the spirit of this federalist project. One of the founders of this organization, Jean Bareth, defined twinning as "the coming together of two communities seeking, in this way, to take action with a European perspective and with the aim of facing their problems and developing between themselves closer and closer ties of friendship" (Council of European Municipalities and Regions, n.d.). Besides federalist aspirations this project was pursued by regional municipal organizations to avoid the bureaucratic procedures present at the state level and to engage in exchanges with other municipalities directly (Weyreter, 2003). Town twinnings gradually became commonplace in the 1950s and 1960s and were used to build bridges between the East and West in the Cold War. They were also practiced between Western and underdeveloped communities to deal with issues of hunger, poverty and environmental protection (Zelinsky, 1991). This international cooperation aspect of twinning was championed in a 1971 UN General Assembly resolution that indicated that twinning was "an exceptionally valuable means of co-operation" and asked the Secretary-General to study the possibilities of expanding this practice (UN General Assembly 26th Session, 1971). Since 1989, the European 
Union became one of the official supporters of town twinning programs by providing funds for the gatherings of citizens from different parts of the continent.

Institutional twinning programs in the form of secondment of experts abroad exhibit many similarities with town twinnings. Both practices take place at the level of people or organizations, usually bypassing the higher levels of inter-state relations. Visits between the counterparts and a concern for mutual understanding can also be counted as common denominators. Some types of twinning projects also take advantage of the face to face contact between the providers and recipients of international assistance.

Visits from the providers to the recipient locale and vice versa are intended to nurture "mutual understanding" between the two parties. But visits are not only meant to fuse the horizons of the nations. This practice needs to be thought within the context of the disciplinary techniques of examination (Foucault, 1979). As argued in Chapter 2, the examination is a mechanism that produces effects of power by making its objects visible. The examination of individuals in schools, prisons, hospitals produces knowledge which is deployed to punish, train and shape them. In ideal conditions, individuals are subjected to constant surveillance, all of their behaviors are compared to the rule and a system of punishments and rewards are applied to achieve conformity with the norm (Foucault, 1979, pp. 170-195). Closed institutions like prisons, camps and schools provide better conditions for the implementation of this type of power but global politics also contains disciplinary practices.

"Fact-finding missions" deployed by international organizations of various sorts shows that the link between visibility and power is also relevant for the international sphere. As tools to produce truth, these missions top the list of the international diplomat 
who seeks to resolve problems peacefully. Such missions in international politics have been conducted at least since the 1931 invasion of Manchuria by Japan. ${ }^{93}$ Usually, factfinding missions require "on the spot" presence of examiners, who are selected for their impartiality and knowledge of the general rules of international life that apply to the situation in question. These "fact-finding missions" lack the regularity of the examination, and do not necessarily produce an "archive" (Foucault, 2007a, p. 189) through which the development of an individual case is traceable. In fact-finding missions, on-site presence provides access to facts and an appreciation of local circumstances, as well as a means of verification of previously received information. Whereas the examination operates on a continuous basis to monitor its objects and compare them to the norm, fact-finding missions are often ad-hoc and focused on finding out what happened in the past.

The visit procedure used within twinning projects is closer to the examination mechanism than to fact-finding missions. Twinning visits are similar to the visits deployed regularly by social workers to monitor recipients of various forms of social assistance or by the CPT to monitor places of detention in Europe. The main difference between these regular visits and twinning visits is that the latter is not constant but applied only for the duration of the project. As will be expanded below, both the European Commission and the twinning experts monitor the implementation of the project for a certain amount of time. The references to cooperation and common purpose seek to downplay the signs of hierarchical observation. In twinning projects, visits to the locale and long stays also make possible the formulation of "solutions" that would be

\footnotetext{
${ }^{93}$ In this case, the League of Nations established a commission of inquiry and sent a mission to China to gather information about the incidents that led to the invasion of Manchuria (Dennett, 1932).
} 
more appropriate to the local setting. It is a way of embedding the experts in the environment so that they can better appraise the conditions and adapt their solutions to the local setting. The common motivation of both the visit and the on-site presence is that interactions at the individual level can be an important resource to confront problems effectively. Implications of mutuality, understanding, informality and localness of "twinning" can be cited as several reasons why international development experts adopted this term when naming a certain strand of technical assistance (TA).

Technical assistance programs became widespread after the end of the Second World War. These programs reconstructed traditional international relations of diplomacy and statecraft as relations of "techno-economic development" between Western nations and "underdeveloped" countries (Mitchell, 2002, p. 41). International assistance programs were motivated by the liberal political rationality's conviction that non-Western peoples should be improved so that they can acquire the capacities to govern themselves (Hindess, 2005). As Hindess explains, with the "postimperial globalization of citizenship" (p. 255), namely the extension of the presumption of self-government capacity to non-Western populations, the basic mode of liberal intervention to improve these populations shifted from colonial methods (and mandate system) towards regulation through international political and financial aid. ${ }^{94}$ Within the liberal mentality, nonWestern populations were no more the "sacred trust of civilization" but they had a certain agency which was in need of improvement and capacitation programs. The basic features of these programs noted by Mitchell are also observable in the twinning projects under consideration here. What these programs did was not a transfer of expertise onto a clean

\footnotetext{
${ }^{94}$ Hindess goes on to argue that the promotion of good governance and human rights globally is meant to enhance the capacities of non-Western peoples (Hindess, 2005).
} 
slate. There was already a body of knowledge in use, but technical assistance aimed to transform this knowledge through the deployment of pilot projects. Indeed, as seen in the previous chapter, technicalization of the problem of torture, emphasis on scientific methods in law enforcement and a novel conception of evidence were already being discussed in the Turkish bureaucracy.

The second feature relevant to our context is the way such practices treated failures of technical assistance. When schemes of foreign assistance did not work, this was not only overlooked but also used to justify new schemes of aid (Mitchell, 2002, p. 42). As will be seen in the genealogy of twinning, this mode of delivering aid came to the agenda as a result of the failures of previous technical assistance programs. Failures need to be seen as integral to any project of government (Hunt \& Wickham, 1994). Indeed, most failures breathe new life into the enterprise of government by reproducing the need to devise new programs and projects, thereby advancing the inventiveness of power. Much like economists who view economic crises as "opportunities," experts of good governance see failures as chances to take new initiatives and expand their influence.

The spreading of institutional twinning can be traced back to the 1980s when the delivery of international development assistance was being critically rethought and reevaluated by the international development community. Lauren Cooper, then a consultant in the Projects Policy Department of the World Bank, indicates that institutional twinning was initially promoted by the International Water Supply Association and the International Association of Ports and Harbors and mentioned in a UNDP report in 1975 (1984, p. 6). In the 1980s, international expert discourses cast a doubt on traditional technical assistance in parallel with the neo-liberal reorientation of the development 
paradigm. The traditional forms of development assistance were (1) physical infrastructure and technology assistance, (2) provision of technical expertise and training and (3) financial support (Berg, 1993, p. 48). Although there are various definitions, it is safe to say that the term Technical Assistance comprised projects composed of the first and second elements of this triad (Walker, Roberts, Jones, \& Frohling, 2008). Especially in the aftermath of the Second World War, the modes of assistance preferred by the Western nations were infrastructure investments, technology transfer and short-term development consulting delivered by expatriates. Dam construction projects, agricultural implements and advisory and policy reports addressed to public administrations were examples of these forms of assistance. These forms were used both in bilateral development assistance and by international agencies such as the United Nations Development Program. In the 1980s, organizations such as IMF and World Bank came to problematize the capacities of different "public sectors" to deal with exogenous conditions, such as economic crises. Lack or insufficiency of local capacity to monitor the economic situation, diagnose problems and produce solutions were seen as the basic causes of the failure of developing nations, especially on the African continent. This required an intervention by development professionals to deliver assistance in the form of expertise on managing the economy and finances of a country. The developing nations needed their own institutions to cope with exogenous conditions and create growth, rather than being dependent on the West for infrastructure or expertise (Jones \& Blunt, 1999; Martella \& Schunk, 1997).

This shift in the development thinking led to a diffusion of "soft TA" defined as "institution-related TA such as assistance for institutional development through improved 
management, organization, training and policy-advice" (Buyck, 1991, p. 6). After the end of the Cold War and the fall of communism, the demand for this form of technical assistance has increased especially in the Eastern and Central European countries (Walker et al., 2008). This tide in development assistance has ebbed a few years later when internal reviews of the World Bank and other organizations cast doubt on the effectiveness of TA. The disbelief was focused less on the ability of any initiative to assist development at all but on the modes of delivery that were employed by the international community. A World Bank report pointed out that the main concerns with TA were "design problems" and "implementation problems." Programs of TA were not designed to ensure the involvement of recipients; their needs were not properly assessed; and in certain cases terms of reference were not available. Regarding implementation, the problems were low performance of the experts and insufficient management and supervision (Buyck, 1991). UNDP-sponsored studies on the shortcomings of TA found that similar criticisms were being voiced by the developing nations. Recipient governments expressed dissatisfaction with the way development assistance was imposed on them and demanded more flexibility in selection of TA personnel and performance evaluation (Berg, 1993). These criticisms were not limited to the field of technical assistance, but were relevant also to a wider scope of global governance institutions including the World Bank and International Monetary Fund (IMF). Indeed, as Jacqueline Best (2007) shows, erosion of "expert legitimacy" of the IMF and failure of its recipes in the 1990s have led to the adoption of a series of "country ownership" measures to improve the legitimacy of international assistance projects in the eyes of the recipients. Practically, ownership meant that the recipients of assistance would take part in the 
formulation of the terms of the program and assume responsibilities in its implementation (Best, p. 478). The contractual character of twinning projects, which will be analyzed below, is designed to engender such an ownership by the recipients.

Institutional twinning came on to the agenda in this context. Twinning was touted as an instrument that could be more effective than other development tools in certain contexts due to several reasons. It could solve design problems, such as the involvement of the recipients, and improve recipients' commitment by rendering this form of technical assistance more open to their demands. When twinning projects are spread over a longer period of time (usually not less than a year) there would be room for incorporating the views of the recipients and modifying the aspects of project by taking stock of the "local conditions" and developments. In addition to this, a typical twinning project involved a "need analysis" or "diagnostic phase" (Cooper, 1984, p. 39) where the shortcomings of the recipient organization was identified in cooperation with the members of that entity and put in the twinning contract. A World Bank technical report said quite frankly that “twinning may... provide psychological or even political advantages, in that twinning contract gives at least the appearance of a two-way exchange" (Cooper, p. 4). Sensitivity to local values and conditions and the collaborative feature of twinning is brought to the foreground by other experts as well (Askvik, 1999; Wallace, 1990). This aspect of twinning testifies to the calculated character of this practice of international assistance. This point is in contrast to the studies on norms in international relations literature in several ways. As pointed out in Chapter 1, studies on socialization of states into international human rights norms often argue that this happens through channels like persuasion, social learning, etc. I had pointed out that such a vocabulary may not always 
be sufficient to capture the techniques used in the dissemination of norms and may miss the strategic aspect of this relationship. As can be seen from the reports on twinning, the dissemination of norms is effected through calculated tactics to influence the psychology of the recipients. It contains a certain "thought" and calculation and cannot be viewed as a spontaneous or "natural" act of persuasion. This finding is also relevant for David Chandler's (2004) argument that capacity-building projects can be understood with reference to the Western nations' search for domestic legitimacy. The calculated character of twinning shows that this practice has a logic and problematic of its own which cannot always be explained in terms of the larger processes of the Western need for legitimacy. While legitimacy is clearly a concern, the shift towards participatory tactics is also way of securing the projects' tasks by including the voice of the other.

Another aspect of the technology of twinning concerns its tactics of demonstration and training. The development community was aware that the recipients found the prescriptions of the Western organizations unrealistic and at times utopian. It was thought that the greatest antidote to this could be the demonstration that a prescribed system works in practice rather than writing up a report on what is to be done:

Instead of relying solely on the recommendations of a study to guide it on what to do and how to do it, the client can turn to a tangible 'twin' entity and see concrete examples and practical applications of the principles... (Cooper, 1984, p. 4) Twinning projects aim to transform views of the recipients regarding what is possible by introducing them to organizations that actually employ the system (or a similar system) recommended by the project. The organization that already used a recommended system was dubbed "supplier." More concretely, supplier organizations 
could be a bureaucratic department or a private company. As a World Bank expert puts it, twinning brings "proven and successful ways of improving organizational efficiency and effectiveness" (Buyck, 1991, p. 90). The practical, in situ demonstration of twinning projects seeks to transform what the recipient organization sees as possible, by targeting the truth regime of the recipient organization. This expansion of the universe of possibility is actualized through two main mechanisms. One is the selection of organizations with similar functions, which constitutes one of the basic tenets of twinning, and the second is utilization of visits. Development professionals calculated that when entities in the same business are twinned, their common experience and interests will make them fit together naturally (Berg, 1993). "Partners" will discuss the similarity of their challenges, how they experience comparable difficulties and the ways of overcoming them. This will lead to a more "dynamic co-operation atmosphere" and more effective learning (Swedish International Development Agency as cited in Jones \& Blunt, 1999, p. 384). Cooperation between entities with a similar mandate also means that the recipients will be able to take advantage of the expertise of the organization: Because the supplier is already accustomed to managing an organization with a similar scope of functions and tackling similar operational problems, the supplier is able to tap into a reservoir of operational experience and in-house resources to address recipient problems in a manner that is rarely possible among consulting firms or individual consultants. (Buyck, 1991, p. 90)

The mechanism of visits were also suggested by many development experts and widely used in EU's twinning projects with candidate countries. Visits were designed to give the recipients a chance to observe how the proposed model worked in practice 
thereby influencing their frame of reference (Proctor, 2000). Study tours to the supplier organization is claimed to help the dissemination of experience through the recipient organization. Unlike traditional technical assistance, the information presented is not confined to upper levels, "more participants interact at more levels, leading to a more pervasive institutional impact" (Berg, p. 118). Twinning relies on interpersonal interaction at other levels as well. Development professionals seem to emphasize the significance of the personalities and leadership traits of the suppliers although it is not always possible to procure such people in twinning projects (Buyck, p. 26; Cooper, p. 16). Such personalities are useful in twinning because role modeling or coaching are seen as effective means of training especially when the target is composed of adult learners. Cooper points out that when the twinning is delivered by an organization that is wellknown and respected there is the chance that the recipient organization may derive a "sense of pride" $(1984$, p. 3$)$ from its collaboration with this organization, which in turn contributes to the success of the project.

\subsection{The European Union and Twinning}

As seen above, twinning as a technology was not limited to a simple transfer of knowledge but relied on other relations of power between individuals to produce desired effects. Its operation was not limited to the provision of expertise but sought to take advantage of the psychological interactions of leadership, motivation, influence and partnership. Twinning went beyond conventional frameworks of international relations and introduced these affective elements into the territory of government. Deployment of such variables and elements by twinning projects indicates that this technology engages in what Rose has called "etho-politics" (Rose, 1999a, pp. 476-478). Rose developed this 
concept to understand a series of transformations in the territory of government in English-speaking countries. As the social citizenship that encouraged a cohesive national identity and solidarity gave way to the neo-liberal technologies of government, there emerged new "techniques and practices" where individuals re-invented themselves according to new lifestyles, values, mores and tastes. This implied a "fragmentation of the social" (Rose, p. 477) where membership in a national totality was exchanged with membership in smaller communities. Therefore, instruments of the nation-state such as welfare state or national ideologies became less useful in guiding the conduct of individuals in their specific life-worlds. This led to the deployment of ethos, that is, "sentiments, values and beliefs" of persons, as a means to connect self-government with the "imperatives of good government" (p. 477). Twinning engages in a similar work of connecting the personal domains of emotion, motivation, value and professional identity to "high-level" objectives of European integration, peace and stability. As will be more apparent in the pages below, twinning projects seek to harness the search for psychological gratification, professional satisfaction and interpersonal affective interaction to the objectives of European integration and promotion of democracy.

When the European Commission decided to import this technology from the international development community, it borrowed these aspects of it but also modified the technology according to its own aims. The adoption of twinning by the Commission took place as a result of the problematization of the available instruments of the EU in the 1990s (Svensson, 2009). As is well known, the early 1990s was the time period when membership to the EU became a possibility for Central and Eastern European countries (CEEC). In the 1993 Copenhagen European Council, member states of the EU virtually 
extended an invitation to these nations and set the criteria for admission. Yet the Union indicated that there was a noticeable gap between the legislation and practices of the member states and the candidate countries. The Essen European Council of 1994 decided to launch a "pre-accession strategy" to overcome this problem. The EU was concerned principally with the functioning of the internal market after the accession and suggested measures such as increased dialogue, preparation of a "to do list" for the CEEC in the form of a Commission White Paper and monitoring adoption of the acquis (European Council, 1994). The Council also pledged to make "organizational arrangements for providing the specialized technical assistance needed."

Until 1998, this technical assistance was put into practice at the level of governments and ministries in fields connected to economy, environment and agriculture. TA projects were initiated on the basis of requests from the candidate countries (Bailey \& De Propris, 2004, p. 79). However, the member states grew dissatisfied with the results of TA projects as the latter failed to deliver the legislative and practical changes required to meet the admission criteria. The consulting provided by the private companies was found to be wanting due to their lack of experience in public administration (Tomalová \& Tulmets, 2007) and problems at the design and implementation stage of technical assistance such as vague objectives; difficulties in monitoring progress also contributed to the unpopularity of these projects (Papadimitriou \& Phinnemore, 2003). The situation also exposed the difficulties experienced by the EU in international government of the newly independent European nations. The EU was not designed to "improve" the countries that sought membership and consequently it lacked the wherewithal to transform its new neighborhood. 
These challenges led to formulation of a new enlargement strategy by the European Commission in the Agenda 2000 document where it suggested the adoption of a "reinforced pre-accession strategy" by the member states (European Commission, 1997, p. 83). This proposal was accepted by the Luxembourg European Council in December 1997. This strategy, in line with the conclusions of the Madrid European Council of 1995, problematized the "administrative capacity" of the candidate countries. This meant that while the Commission saw "political will" in these countries as sufficient, it also realized that it could not be translated into implementation due to problems in the institutional machinery. As a remedy to the problem of administrative incapacity, and as part of the new pre-accession strategy, twinning projects were suggested by the Commission:

Transposition of law is important, but it is equally important that administrations are modernized so that they can implement and enforce the acquis. This will require new administrative structures as well as properly trained and remunerated administrations. (European Commission, 1997, p. 46)

The new pre-accession strategy framed the accession process within "Accession Partnerships" (AP) and brought previously dispersed elements of assistance under a unified framework. This instrument (AP) literally provided a list of things to do by the candidate country, which in turn would respond with a National Program for the Adoption of the Acquis (NPAA) of its own, including a timetable. Thus the Commission created a system where EU pledges in the form of technical assistance, investment and financial resources would be met by precise commitments and timetables by the candidates. 
This ongoing process would be monitored by the Commission with Regular Reports first to be published in 1998. The NPAA and "Progress Reports" written by the European Commission turned out to be significant documents for the justification of twinning projects. Project documents frequently referred to the NPAA to justify the changes suggested by twinning experts. Since the NPAAs were adopted by the governments (usually by national cabinets) and printed in the Official Gazettes, reference to these documents in twinning implied that European experts were reminding the candidate countries of their own pledges. Progress reports satisfied a similar function. Although they were not authored by candidate countries, they were acknowledged by their Foreign Ministries and seen as reference documents.

The progress reports, moreover, showed that the EU was borrowing techniques invented in the early twentieth century to govern candidate countries. In the second chapter, we have seen how international experts developed reports as monitoring devices deployed in the surveillance of both the mandatories and the mandated territories. These tools of international government were reconfigured under EU membership process and deployed to govern the accession process and the candidate countries. Similar to the experts at the League of Nations, the European Commission relied on the press, on parliamentary debates, and on local political actors to inform itself about the situation of the country. The delegations of the European Commission in candidate countries, which have become part of the European External Action Service following the entry into force of Treaty of Lisbon in 2009 , made this work of monitoring even more routine and effective. Twinning projects took this surveillance a step further by closely integrating on-site training and continuous on-site monitoring. 
Agenda 2000 mentioned twinning as "exchanges and long-term detachment of experts from the member states to the applicant countries" (European Commission, 1997, p. 46). This was an important development in terms of the diversification of the EU's technologies of government. The twinning can be seen as a method of "governing at a distance" (Kendall, 1997). Kendall uses this term to describe the relationship between Britain and Australia in the second half of the $19^{\text {th }}$ century. He argues that in this period a new thinking emerged which regarded coercive administration of Australia by London as both impractical and contrary to liberal philosophy. To ensure the fidelity of the "England of the South" (Kendall, p. 231), London used means such as the moral education of the colonists, spreading English culture, and using feelings of commitment to the mother country. The utilization of twinning can be seen in a similar light although the historical circumstances are much different. The EU lacked any means to train large populations of the candidate countries or coerce them into accepting European rules. Yet, after the adoption of twinning, EU would not only use conditionality and traditional diplomatic methods to govern the conduct of the candidate countries but would also use twinning which brought together techniques such as benchmarking, monitoring and a variant of the visit. The adoption of the twinning mechanism helped Brussels manage the enlargement process and ensure the candidates' compliance with the Copenhagen Criteria. This technology recognized the autonomy, distance and difference of the candidate countries and the EU's structural shortcomings in governing the conduct of such countries.

The European Commission has produced several documents to publicize this technology and explain how it functions. The Twinning Manual, a version of which was published in 2009 (European Commission, 2009) is a central text which lays out the rules 
and constitute the subjects and objects of this process. As I argued in the introduction, twinning as benchmarked harmonization involved the supervision of the project to ensure that it accomplished its objectives. The manual distinguishes twinning from traditional forms of technical assistance by emphasizing the "mandatory results" (European Commission, p. 14). These results would be "measurable and precise" objectives agreed between the EU and the candidate country, such as "an intermediate benchmark, which constitutes a specific criterion in relation to administrative capacity" (European Commission, p. 14). For instance, a twinning project on human rights would include mandatory results such as the establishment of procedures for police complaints. ${ }^{95}$ At the end, the projects have to put in place a "system" with operational results, going beyond the technical advice and transposition of new legislation. In most cases, this means that the candidate country will establish a new administrative unit or adopt a new practice.

In line with the recommendations of development professionals, the technology of twinning is built upon "needs analysis" where the gap between the candidate and EU practices are identified and inscribed in the Accession Partnership and National Program documents. Looking at this needs identification; the Commission and the candidate country prepare a "project fiche" interested bodies can submit proposals. On the basis of these proposals, the member states make a presentation to the candidate country authorities and the latter choose among them according to the "affinity with the administrative system in place in that

\footnotetext{
${ }^{95}$ This aspect of the benchmarking is similar to analytical practice found in disciplinary regimes according to Foucault (1979). Such regimes often divide the normal behavior into manageable and smaller chunks which makes observation and normalization more efficient.

${ }^{96}$ Project fiches are documents prepared by "beneficiary country" and the EU Commission to identify what the beneficiary needs in terms of technical assistance, the duration, overall objectives and budget of the project. Upon approval it is circulated in the EU member states to invite proposals for the twinning project. It can be seen as a detailed call for tender.
} 
member state and an analysis of the experts proposed... the choice of partner is entirely left to the Beneficiary Country" (European Commission, 2009, p. 37). This is the marketlike element of benchmarked harmonization. After the selection of the twinning partner or partners, the parties prepare and sign a "Twinning Covenant," to be approved by the Commission. The covenant identifies the tasks required to meet the Copenhagen criteria and lists the result to be achieved.

The choice of the term, covenant, seeks to render this bureaucratic process into a moral relationship between a candidate country that makes pledges, and the Commission that trusts in these promises. Aside from this mood, the market logic was also introduced to the twinning projects. As the European Commission cautions, the choice should be entirely dependent on quality of the proposal since the budget of the project is more or less fixed. Yet, there is still an ethos of tender where the beneficiary country is able to select among the available options. The marketization of technical assistance was an option proposed by Berg $(1993$, p. 31) as a solution to the high prices of technical assistance and supply-driven projects. He thought that a market would lead the beneficiaries to "choose wisely" and economize during implementation. The introduction of market techniques to twinning produces similar effects. It leads the candidate countries to behave according to a certain model of economic rationality and to focus on the advantages of the "products" presented, suitability of the proposals for their needs, and skills of the experts of the member states and the potentials for rapport between them. In short, the supply and demand needs to be matched. It also instills a certain sense of responsibility and even autonomy in the beneficiaries by letting them make choices. This underlines the mutability of relations of power, or what Collier has called the "topologies 
of power" (Collier, 2009). As pointed out in Chapter 1, Foucault talked about three modes of power: discipline, sovereignty and governmentality. All of these modes had their own logics and objectives. Collier argues that power relations in certain political forms should not be seen as expressions of a single and unitary logic, but rather as a hybrid and mutable configuration of different elements (p. 81). In line with this, twinning projects can be seen as a governmental technology that conducts the conduct of others through their autonomy and freedom, as seen in the use of benchmarking and contracting. However, this does not extend to all manifestations of the twinning practice. Other logics, such as governing through the market, can also be integrated into these practices.

Despite the emphasis on guaranteed results, twinning is not meant to produce homogenous public administrations across the European Union. It aims harmonization. Especially in areas such as the political criteria of admission where the acquis of the Union are thin, the pledges of the candidate country take vague forms such as to "introduce legal provisions on the joint and several liability of perpetrators of torture" (Council of Ministers, 2003, p. 23). This autonomy is built in to benchmarked harmonization as it aims to "meet the same standards as those in Member States" (European Commission, 2001, p. 6) and "solutions are as diverse as the problems" (p. 9). Thus, the technology of twinning shares the logic of the Open Method of Coordination (OMC) in the European Union, the term coined in 2000 but whose aspects arguably were introduced much earlier (cf. Tulmets, 2005a).

According to Walters and Haahr, OMC operates by authoritative definition of overall strategic objectives which are quantified and connected to timetables and systematically monitored (Walters \& Haahr, 2005a). The decision makers set the goals 
and expect the other actors to reach these goals within a given time period without interfering in how they accomplish this task. Thus, OMC is a form of government at a distance and relies on the self-government of other actors. The above analysis suggests that twinning technology is in many ways similar to this form of government. In this technology, the Commission refers to the Copenhagen Criteria, which stand for overall objectives of the pre-accession strategy, but does not necessarily interfere in how the candidate countries meet these standards. Yet, the candidate countries are not completely left on their own either. They are committed to this strategy and their conduct is governed at a distance through twinning projects.

In order to locate benchmarked harmonization along a continuum of international interventions, we can compare it to Western humanitarian initiatives in the Balkans. Providing an ethnographic account of humanitarian apparatuses, Mariella Pandolfi has described the intervention of the international community in post-conflict situations as "mobile sovereignty" (Pandolfi, 2002) or "mobile oligarchy" (Pandolfi, 2010). According to this, a coalition of international organizations, NGOs and Western states seek to save human life by providing food, security and shelter to victims of conflicts. In some cases, the intervention extends into the post-conflict period through the construction of structures of good governance such as the United Nations Interim Administration Mission in Kosovo which assumed state functions. This intervention reproduces itself, ultimately rendering the post-conflict situation permanent (Pandolfi, 2010) and rearranges the politics of the society by supporting certain elites as opposed to others through funds and expert reports (Pandolfi, 2002). Twinning experts and European officials associated with twinning projects carry out a similar intervention in candidate state practices. Their 
intervention is not as drastic as to deserve the label oligarchy. Yet they introduce significant novelties, what they call "procedures" to transform working styles of bureaucracies in these candidate countries. We should also recognize the difference between instances of mobile sovereignty in Balkan states and Turkey. Twinning is applicable to post-conflict societies, but Turkey has not been described as a post-conflict society in policy discourses despite the low-intensity conflict in the southeast. Indeed the complex national bureaucratic and political processes that are required for initiating the projects show that the Turkish state is very jealous of its sovereignty (anonymous expert, personal communication, June 28,2007$)$. Moreover, twinning projects are not designed to establish links with the citizenry and thus do not have the capacity to shape "civil society" actors. However, benchmarked harmonization also produces its own constituency. Especially the middle and high ranking police officers see twinning projects (or similar international projects) as an opportunity to work with foreign officers, advance their foreign language capabilities, expand their experience, stand apart from the other officers and therefore advance their careers (anonymous police officer, personal communication, June 26,2007$).{ }^{97}$

How is this accomplished? Similar to the OMC concept, twinning projects have benchmarks written into the project fiches and Twinning Covenants. They include both intermediate benchmarks and results to be obtained. The projects are monitored at several levels with reference to these benchmarks, which need to be accomplished within a

\footnotetext{
${ }^{97}$ A similar tactic to lure police officers into compliance with human rights is seen in the Russian Federation. According to Taylor (2006), Citizens' Watch, a Russian NGO, seeks to change police officer behavior through the use of "material incentives and enhanced prestige" (p. 200). These include the prospect of foreign travel and contacts with foreign police professionals which can be helpful for advancing professional careers of officers.
} 
certain period. First, the Commission reviews the project progress several months into its implementation to see whether any modification or termination is necessary. While the country delegations of the Commission keep an eye on the project, the member state officials are also required to prepare a report with the input of the beneficiary country every three months. The Commission also contracts independent reports of twinning projects but these do not have immediate monitoring effects (European Commission, 2009). In this way, the project and the officials working within it are subjected to a performance check on a quarterly basis.

Aspects of contractualism can also be found in the functioning of the twinning technology. Contractualism constitutes the relation between the member state, the candidate country administrations and the European Commission as a scheme of commitments where each party promises to perform certain tasks in return for the performance of the other (Walters \& Haahr, 2005a, p. 122). This relation replaces the cooperation spirit whereby parties are each committed to a common objective and work together to achieve it. Contractualism, in alignment with benchmarking, breaks down the operation of the public administration into individually identifiable tasks. It also creates an ethos of responsibilization where parties are attached to specific performances and the European Commission shifts the accountability to the other parties. This can be seen in the design and implementation of twinning projects. At the higher level, the candidate country is responsibilized by having to produce a National Program where it makes specific promises. At the lower levels, the twinning project requires appointment of "Project Leaders" from both the member state and the beneficiary country each of whom "continues to work in his/her... administration but who devotes a portion of his/her time 
to conceiving, supervising and co-ordinating the overall thrust of the project" (European Commission, 2009, p. 14). The names of the project leaders are put on the project fiches and they initial the work plan and budget. Higher officials from the member state and beneficiary country are also required to sign the twinning documents where the latter's signature is "expressing commitment and ownership of their administration" (p. 50). In return for the signs of commitment by the candidate country, the EU proceeds to authorize the flow of experts and funds.

Resident Twinning Advisors (RTA, formerly Pre-Accession Advisor) are the member state officials seconded to the candidate country administration. They are technical experts that work on a daily basis throughout the twinning project. Yet European Commission documents entrust to them duties than go beyond the technical expertise. In line with the World Bank experts' emphasis on the psychological requirements of development assistance, the RTAs are expected to be "flexible and willing" to adapt to the country in which they are working. The success of the project is in part dependent on their ability "to relate to their counterparts and inspire trust as fellow professionals" (European Commission, 2001, p. 22).

RTAs embody a transnational body of governance professionals. They are actors who translate their local experience and knowledge of governance issues like policing, human rights, criminal justice into transferable and mobile expertise. Writing a decade ago, Bigo (2000a) detected a transnational field of policing in Europe exemplified in the rising significance of liaison officers in European security. These officers "interconnect" fields and activities in nation-states, which were previously independent from each other. Now in part due to freedom of movement of goods and people, it has become very 
difficult to conduct policing without reference to other nations' security officials. This trend has also transformed the functions of security officials where military and police became fused and interchangeable actors in contexts such as the policing of migration and terrorism. RTAs herald a similar tendency. For instance, a police instructor in an EU member state can become a human rights expert in Turkey, working with other police officers to devise ways to meet the Copenhagen criteria. A bureaucrat from an Interior Ministry can engage in projects of improving accountability of police officers in Turkey. Officials once thought to be based nationally and possessing parochial knowledges have become mobile professionals in a transitional field of good governance.

\subsection{Turkey's Accession Process and Twinning}

Turkey's relations with the EU can be traced back to 1959 when the ruling Democratic Party applied for associated membership. In 1963, an Association Agreement was signed between the European Economic Community and Ankara. Following the EU's Mediterranean enlargements in 1981 and 1986, Ankara also applied for membership in 1987 (Kirisci, 2005). In its 1989 opinion, the Commission evaluated the application by looking at the economic and political situation in Turkey and said that given Turkey's large population (with implications for European integration) and its low level of development "it would not be useful to open accession negotiations with Turkey straight away" (European Commission, 1989). The Commission instead suggested the strengthening of relations between Europe and Turkey through measures such as a Customs Union. After much nerve-wracking negotiations, the Customs Union was established in 1996. While this was projected as an important development that would carry Turkey's integration forward, several other developments showed that Ankara's 
vocation was full of hurdles. The negotiations on the Customs Union had coincided with massive human rights violations due to the heightened confrontation between PKK and Turkish security forces (Kirisci, 2004). A 1996 crisis between Greece and Turkey over the sovereignty over a small island in the Aegean added to the difficulties. Against this background, the 1997 exclusion of Ankara from the process of accession was not surprising. This decision was reversed in 1999 and after the adoption of several "EU harmonization packages" in the Turkish parliament and the coming to power of the Justice and Development Party (JDP) with a pro-EU platform, accession negotiations between Ankara and EU were opened in October 2005.

The commitment of Ankara and European countries to the accession process has been problematical at best. Nevertheless, with the 1999 decision of the EU Council, Turkey was locked into the pre-accession strategy and the Commission committed itself to take measures to support the reform process in the country. Twinning projects constituted an important part of these activities. In its 2000 Regular Report the European Commission stated that "Turkey has been informed that pre-accession advisors can be made available under the Twinning Program" (European Commission, 2000, p. 9). The language of the 2001 NPAA adopted by Turkish government implies that these projects have been stalled due to a lack of commitment from the European side. In this document, in connection with the chapter on Statistics, Ankara indicates that "technical assistance from the EU is required (for instance through the "twinning" method)" (Council of Ministers, 2003, p. 268). A more remonstrative tone was found in the chapter on Small and Medium Enterprises: “Turkey's participation in the following activities and arrangements of the European Union must be ensured: ...twinning mechanisms open to 
CEECs" (Council of Ministers, p. 372). Eventually, Twinning projects started in Turkey within the context of 2002 Programming of Pre-Accession Financial Assistance (Council of Ministers, p. 774). The Turkish government was protesting that in comparison to the CEECs, they were being discriminated against in the accession process. Therefore, it is safe to conclude that the Turkish side requested the initiation of twinning projects.

\subsection{Twinning Projects Relating to Police and Torture in Turkey}

In this section, I will analyze three twinning projects that were realized on the basis of agreements between the EU and Turkish government. Between 2002 and 2007 , 16 twinning projects have been initiated between EU and the Ministry of Interior (Secretariat General for EU Affairs, 2008). Of these projects, seven projects are directly related to migration issues while four of them are concerned with organized crime issues. There are also projects about property rights, and the establishment of an independent police complaints commission. This study is limited to the analysis of three twinning projects: "Improvement of Statement Taking Methods and Statement Taking Rooms" initiated in 2002; "Strengthening the Accountability, Efficiency, and Effectiveness of the Turkish National Police" and "Strengthening the Police Forensic Capacity". The latter two were initiated in 2003. Although there are other projects relevant to the prevention of torture and ill treatment, these three projects are selected because they are more intimately related than the others to the improvement of the human rights record of the Turkish police. The 2005 project on the police complaints commission is not included since it was still evolving at the time of field research.

Since the coming to power of the Justice and Development Party, the government has made many changes in the legislation to meet the requirements of EU political 
criteria. The police department, which was already undergoing renewal, has received its fair share of reforms in this process. The subsequent decrease in the incidence of ill treatment of the citizens by the police and its success in improving community support have usually been conceptualized as a result of the "mental transformation" of the Turkish public administration and the police organization. According to this discourse, which is ubiquitous in official addresses by members of the cabinet, police officials or newspaper editorials, Turkey is undergoing a far-reaching change where the old ways of governing are being slowly replaced with a new understanding (Dikmen, 2010; Elibol, 2008; Today's Zaman, 2008a). The hallmark of this new understanding is the "reconciliation of the state with the nation." This was not possible before since the state presumed itself to be superior to the citizens and hence ill treatment was justified if it was for the sake of the survival and perpetuity of the state. Under the Justice and Development Party government, the argument goes, previously excluded sections of the population have been brought to the center from the periphery and the state has become a servant of the people. In line with this transformation, the Turkish police have also started to change "mentally."

This mental renovation metaphor is in line with the narrative of ideational transformation, which the government propounds. Moreover, this notion represents new police practices as predominantly mental and ideational changes that take place primarily within the minds of the police practioners. The accomplishment of police reform, the argument goes, has been due to the gradual internalization of human rights norms by the police. The following analysis, aims to show that contrary to this depiction of police reform as an unstructured development, the changes are being effected through 
governmental strategies. Without denying the possibility of change through the internalization of the human rights norms, I also seek to show that the "police reform" has been accomplished through the deployment of technical devices and practices. Discipline, training, shaping subjectivities of police officers and institutions of new actornetworks as well as various artifacts and material devices (such as CCTV cameras mentioned in the previous chapters) are the means used in this process. In other words, twinning projects seek to reassemble police practices by introducing not only new values and legislation but also new techniques and technologies including devices and scientific knowledge into play.

\subsubsection{Strengthening the Accountability, Efficiency and Effectiveness of the Turkish}

\section{National Police}

The first project under consideration here is the "Strengthening the Accountability, Efficiency and Effectiveness of the Turkish National Police." The project was started at the end of 2004 following the selection of Spain's National Police (Cuerpo Nacional de Policía $)^{98}$ as the twinning partner. It had a total budget exceeding 2.5 million Euros and lasted for two years (Secretariat General for EU Affairs, 2008). The main sources of information concerning this project are the project fiche jointly prepared by the Turkish side and the EU delegation in Ankara ("Strengthening the accountability," 2003) and a manual for human rights training including its annexes (Halici Celik, 2007).

The project fiche indicates the "Overall Objective" of the project as "enhancing [emphasis added] the accountability, efficiency and effectiveness of the Turkish National

\footnotetext{
${ }^{98}$ Spain has two law enforcement agencies at the national level. Apart from the National Police there is also the Civil Guard (Guardia Civil). The former has a civilian character and mostly operates in the cities while the latter militarized police is responsible for smaller towns (Amnesty International, 2007a).
} 
Police in the discharge of its responsibilities in respect of the enforcement of law in accordance with democratic principles and having regard for the Human Rights of all citizens" ("Strengthening the accountability," p. 1). This emphasis on enhancement of accountability was significant for the Turkish police. As I was heatedly reminded by an interviewee, this project did not amount to an admission of unaccountability in Turkish police, as some human rights activists charged for many years. Rather, my informant argued defensively, it was a scheme to improve what already existed (anonymous police official, personal communication, June 30,2007$).{ }^{99}$ The project sought to attain this objective by the development and implementation of a Corporate Plan for the organization in addition to the modern training and personnel systems. As such, the project was linked to both the EU reform process that the government was undertaking and its ongoing collaboration with the Council of Europe for training the law enforcement personnel.

The fiche can itself be read as an intellectual technology of government (Miller \& Rose, 1990) over which the EU and Turkish police bureaucracy has struggled, negotiated and eventually formed a consensus as to how the truth about the organization, and reform process will be reported. As a joint document, the fiche reflects the views of both the EU and the Turkish police bureaucracy and at several places reads like a record of a debate between these parties. For instance, a paragraph concludes with critical tones, pointing out that the EU candidacy process requires that the police carry out their functions "with great sensitivity and understanding, respecting democracy and human rights for all

\footnotetext{
${ }^{99}$ This can be taken as an indication that the police department was not interested in coming to terms with its past mistakes or submit itself to a process of detailed self-criticism. That abuses were a mistake was more or less acknowledged but it was implied that the police did what it had to under pressure from the political class.
} 
citizens." The next paragraph, as if trying to respond to this veiled attack, warns that "police officials are carefully selected for their human qualities, properly trained to perform their difficult duties [emphasis added] in an ethically correct manner" ("Strengthening the accountability," 2003, p. 3). In the next page, Turkish police again seems to adopt a defensive posture:

Improvement of police services and practice cannot be realized without improving the conditions in which police carry out their duties. The police work under very hard working conditions. Currently an average Turkish police officer works for 72 hrs a week as compared to $37,5 \mathrm{hrs}$ for the average EU officer" ("Strengthening the accountability," p. 4)

The first "exchange" can be read as a sign that authors of the document saw a need to balance criticisms of human rights with affirmations of the good standing and "self-sacrifices" of the police department. In reaction to the criticisms, the qualities of the organization were emphasized and it was underlined that there is no problem with the human resource of the organization itself. The second exchange attempted to reframe the problem of human rights violations. In analyses of police violence, the factors that are usually taken into consideration are the ultra-nationalist ideology of the members of police officers or official attitudes towards opposition groups. The notion that unfavorable working environment and conditions of the police fuels ill treatment is often emphasized by public officials including the police. By including this factor into the equation, the police organization iterated its longstanding demands for better rights. This textual combat can be read as an indication that the police officials strove to steer the process and at times saw the project as a means to translate their own interests such as 
better working hours or better pay into elements of reform itself. This was a crucial act of translation of human rights reforms by the police department in the sense Latour (1986) used the concept. The police officers seemed to adopt the reforms but while doing that they modified the content of the reform by attaching their own interests and agendas to the success of reforms. Indeed, this was not the first time the police resorted to the discourse and practices of human rights in its search for better working conditions. For instance, Istanbul daily Milliyet reported in 2002 that an officer from the western city of Izmir had applied to the Izmir Board of Human Rights and complained of long working hours (which usually amounted to 72 hours a week), low pay and lack of proper government-funded housing. The board solicited expert reports from two professors of law who argued that the working conditions of the police officers violated the Turkish constitution and the European Convention on Human Rights. These conditions, they pointed out, was detrimental to the fight against crime and could lead to ill treatment of citizens (Milliyet, 2002).

The project fiche problematizes three main areas of police administration in Turkey: the quality of police services, pre-service and in-service training, and the personnel system including promotions and appointments. All of these are described and analyzed in some detail in the project document. Regarding the first issue, the Turkish police was cast in a dynamic process of renewal. This renewal was necessitated by public criticisms and the pressures of adaptation arising from cooperation with foreign police departments in criminal matters. The "Turkish National Police has long been involved in efforts to reorganize to improve its services and performance and wishes to bring sporadic, disconcerted efforts into a comprehensive, strategic framework" 
("Strengthening the accountability," 2003, p. 3). In the text, the quality of services is understood in terms of two basic variables. One is the efficiency of police service, that is, the use of available human and financial resources to provide security to the citizens. The second measure of quality is respect for human rights by the police, especially regarding police custody. The trope of service has been recurring in the police discourse in Turkey since the 1990s (e.g. Cerrah, 1998). Police instructors believed that if the police officers could conceive themselves as a "police service" rather than a "police force" they would empathize with the citizenry and be more "forbearing" in the face of provocation or misbehavior. If the officers saw themselves as a force, however, they could more often "foreground their oppressive side" (Bal \& Beren, 2003, p. 80). The project affirmed this notion of police as service by focusing on the security provided to the citizenry (rather than the state) and the material environment (police stations) as a space of service provision. The project fiche suggests that the police need models and guidelines to follow both for the rationalization of police stations (merger of smaller facilities into larger ones to free officers for patrolling and reduce expenditure) and detention ("Strengthening the accountability," p. 4).

The second problem area is personnel issues. The police organization has "personal [sic] files" for each member of its organization, held by the relevant department. According to the project fiche "the files contain all sorts of personal records" ("Strengthening the accountability," p. 7). The document grants that the promotion and appraisal of the members of the organization does not rely on rational principles. There is an automatic promotion system and officers are usually promoted once they fulfill the minimum waiting years of three to four years. Authors of the document regret that 
promotions are decided by certain committees who do not have any information about the officers other than their files, while confidential performance evaluations are made by managers who "have no education on how to measure success... more objectively" ("Strengthening the accountability," p. 7). The document concludes that the promotions and appointment are either coincidental or political since they are not based on rational principles and reform of this system is necessary to make the organization "more professional and more accountable." As indicated in previous research (Ayasili, 2005), most of the police officers are not satisfied with the way promotions are made. Hence, the inclusion of this element in the twinning project may be seen as another instance of translating police interests into the European integration process.

The third area of problematization is training. The fiche conceded that there is no uniform method in the admission of individuals to the police organization. The government holds the power to accept people to the profession as long as they meet certain criteria such as university degree. In this case, six months of training is seen as sufficient for "graduates" to be appointed as non-commissioned officers. Other routes of entry to the profession include the Police College (equivalent to high school) and Police Academy (giving college and university degrees). The fiche pointed out that education and training "materials are not designed professionally and majority of lecturers in districts do not have a pedagogical background" ("Strengthening the accountability," p. $5)$.

As noted in the previous pages, government has traditionally framed the poor human rights record of the police organization as a problem of education and training. In this respect, the twinning project does not appear to change this frame. However, when 
the issue is considered closely, it is seen that the notion of education used in the twinning project is different from the one emphasized by the government in the past. For instance, as seen in the previous chapter, the police violence in the 1980s was at times excused because of the illiberalism of the officers. Sometimes, torture has been attributed to personal cruelty of the officer in question. I argued in Chapter 3 that, increasingly, the improvement of technical capacities was offered as the main solution to the problem of torture and ill treatment rather than the idea of transmission of liberal norms through civic education. Similarly, the authors of the project fiche envision a technical and practiceoriented training where future police officers are educated to operate in a way that would not violate human rights.

The difference between these two programs of education is emphasized by De Lint (1998). He argues that in the early 1970s, experts in the United States, Canada and the UK began to problematize the way they trained the police officers, and the ideas from management theory were introduced into the institutions that educated police cadets. In the English speaking nations before the 1970s, it was thought that cadet behavior should be shaped through a liberal university education and the "perpetration of more formal rules" (De Lint, p. 282). There existed a similar situation in Turkey, where police cadet training was overwhelmed with submission to rules and lectures on criminal, constitutional and administrative law. Due to the influence of new theories of management that emphasized "participation" of autonomous workers in the decisionmaking process and exhibition of the importance of police decision-making in cases of human rights abuses in USA, Canada and elsewhere there emerged a growing emphasis on shaping the autonomy of police officers. In this context, De Lint points out, some 
argued against more liberal education and instead promoted the conduct of police conduct through the use of "decision-making dramas and dilemmas" (p. 283). The police officers were already absorbing informal patterns of behavior from their peers working in the streets. The training of police could tap into this resource of "street level" policing and improve training with the use simulations such as "judgment drills."

The practicality of police training had emerged as a theme in international expert discourses following the 1992 Review of United Nations training courses for human rights. At the time, human rights training was conducted more like a course in philosophy and law where the participants were introduced to international human rights legislation and the reasoning behind these international norms. Training delivered by academics was scolded as excessively theoretical, wrongfully emphasizing negativity of human rights and lacking practical aspects (Marotta, 1999). In line with the principles of adult education, it was established that training could be effective only if it involved a practical side, realized through case studies, role-playing, simulation, etc (Della, 2004). This sort of training could only be delivered by people with practical experience, namely the police themselves.

This mode of delivering training to police cadets has been discussed in Turkey. Ankara had agreed to engage with the Council of Europe's "1997-2000 Police and Human Rights" program. Within this context, a Dutch technical consultant group had prepared a feasibility study between 1998 and 1999. The project document approvingly quotes the findings of this study, a summary of which is also annexed to the fiche. The findings are strikingly similar to the conclusions of the 1992 UN review: that human rights training in the Turkish police is too theoretical and that practical programs are not 
sufficient. The study suggested that the police use situation-based training and real-life simulations. The twinning project involved a module of police training inspired by the findings of this study. The development of police training programs was envisaged with a view to identifying the requirements of the police organization, preparing a practical curriculum and material and designing facilities where this kind of a training can take place ("Strengthening the accountability," 2003).

Part of what the twinning program has accomplished in terms of training materials can be found in the manual and its annexes developed for this project (see Halici Celik, 2007). The Turkish police were twinned with the Spanish police in an arrangement aimed at transferring EU "best practices" into the Turkish training procedures. This notion of "best practices" reminds us that the twinning technology conceives the police function as a series of discrete practices, which can be handpicked and promoted as "best practices" whatever the general context of human rights situation in an administration. The Spanish policing authorities have been accused of torture and ill treatment, especially in relation to detainees of Basque origin (Morentin, Callado, \& Idoyaga, 2008). Law enforcement authorities in Spain, including the National Police selected for twinning in this project, do not have a clean record in terms of ill treatment or accountability. Reports allege that while ill treatment by Spanish officers is not routine, authorities fail to make an effective investigation into accusations ${ }^{100}$ (Amnesty International, 2009). Despite the deficiencies in the accountability of police officers in Spain, the twinning concept allows Spanish National Police practices to be touted as "best practices." Moreover, through twinning,

${ }^{100} \mathrm{AI}$ reports that one of the allegations that was dismissed by the internal investigation was submitted to the ECtHR which concluded that there was violation of the prohibition of torture (Amnesty International, 2009). 
Spanish practices are promoted in Turkey to strengthen accountability. Another advantage of the twinning technology is that it provides opportunities for the receiving administration to show that it is being transformed in cooperation with the European partners. A case in point is a statement given to the press during the twinning projects that the human rights record of the police is being improved thanks to the cooperation between EU and Turkish police (Erzurum Gazetesi, 2005). By foregrounding its cooperation with an official body in a European member-state (in this case the Spanish police), Turkish police officers are able to construct a new image for their organizations. Association with a transnational field becomes a source of legitimacy for the Turkish police department.

The training material produced as an outcome of the project is based on a

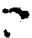
practice-oriented, experiential concept. This training method is contrasted with theoretical education where the participants are simply expected to learn the appropriate international and domestic human rights law. The expected outcome of such training would be absorption of the correct knowledge that in turn informed correct action. The training promoted within this project, however, supplants this book-learning approach with self-exploration, reflection on one's own values, and implementation of the "right values" in practice. A Council of Europe manual, which seems to be the inspiration of the materials produced in the twinning project, articulates the thought behind this training method:

In using this manual, the trainer's role is to guide the discussion and to allow students to become active participants in their own learning and that of each other. Research has shown that an attitude change is more likely as the result of a 
discussion than a lecture... The police officer must learn to evaluate his/her own behavior and decisions... A better understanding of one's own motives, behavior and attitudes, essential if any change in these is to be achieved. (Osse, 2000, p. 9) In line with this, the manual produced in the project defines the task of the trainer as "intervention in perceptions of human rights through education" (Terorle Mucadele Ve Harekat Dairesi Baskanligi, 2007, Chapter 1, p. 19) This is to be accomplished in several ways. Trainers can hold participatory discussions within the class to get the students to reflect on their own values and then replace them with the correct values if necessary. The trainer first asks the views of the police officers on human rights. The trainer puts all (negative) views such as "human rights prevents effective police work, criminals do not deserve human rights" on the board to make the participants reflect on them. Next, the trainer tries to "cleanse negative perceptions" by explaining why these views are wrong (Chapter 1, p. 20).

The trainer can also use practical activities like role-playing to instill empathy in the police officers towards groups such as refugees or "veil of ignorance" game to show that human rights are necessary for everyone, including the police officers themselves. The "veil of ignorance" is a procedure introduced by John Rawls in his $A$ Theory of Justice to find a universal basis for justice (Rawls, 1999). The idea behind this procedure is that when defining principles of justice, individuals may tend to support principles that are advantageous to themselves, rather than ones that would be in the interest of all. To prevent this, individuals are asked to think about a future society. However, they are ignorant about their positions in this society. They could be a member of a disadvantaged group or be privileged. Since such prospects are not known, the individuals are led to 
settle on principles of justice that are most objective, and this represents a true consensus (Rawls, pp. 118-122). This liberal notion underlines that the principles of justice result from an agreement among individuals and these principles cannot be sacrificed to socalled higher values of security or the welfare of the majority.

By translating this liberal precept into a role-playing game, the twinning project aimed to show that human rights principles are not particularistic ideas defended by persons with questionable motives. Similar to the "veil of ignorance" procedure, the officers were divided into small groups and told to imagine a new country. Then each group is asked to come forward with a list of 10 rights that they see as most indispensable in this new country. When the resulting lists were discussed by the officers, they were expected to observe that not only were their lists were very similar to each other but also that it comprises a "simplified version of UDHR" (Terorle Mucadele Ve Harekat Dairesi Baskanligi, 2007, Chapter 1, p. 24).

The rationale for this method of training based on experience is found in the training manual annexes. Police officers who are targeted in training are constructed as adults with real-life experience, disliking strict authority, potentially resistant to training and interested in knowledge that is practical rather than, emancipatory or simply pedagogical. They are presumed to be individuals who can easily get bored and hence subvert the purpose of transformation if their voice is excluded from the process. Officers, as adults, do not operate merely on the basis of rational principles. They have strong emotions, which can be harnessed through affective tactics by the trainers. Their already existing skills should be honored, creativities encouraged, and experiences appreciated within a context of amicable competition, interaction and dialogue. For the 
construction of a productive environment, trainers should avoid excessive criticism, praising the students before correcting them and giving them opportunities to correct their own mistakes (see Halici Celik, 2007). Thus, twinning made use of etho-political tactics to instill human rights appreciation into the officers and to improve their practices.

\subsubsection{Strengthening Police Forensic Capacity}

This project was prepared in 2003 and initiated in 2005, with a budget close to 6.5 million Euros (Delegation of European Commission to Turkey, n.d.). Turkish police teamed up with Germany's Federal Criminal Police Office (Bundeskriminalamt) in a 24 month project (European Commission, 2007). The project identified its objective as "to consolidate a functioning democratic system, including respect for the rule of law through the integration of modern scientific methods into Police investigative practices" (Delegation of European Commission to Turkey, n.d.). This objective underlines the EU belief, which is a common theme in transnational expert discourses, that policing is an essential factor when it comes to the realization of democratic political life. This project also affirmed the idea that scientific artifacts such as crime scene investigation, DNA databases and laboratories can contribute to these political objectives.

Scientific artifacts need to be thought of in relation to their political and social functions. As Cole (2001) argues, such artifacts of criminal identification were initially deployed to locate potentially criminal individuals and populations. The corpus of knowledge developed for this purpose was then used by other scientists to track actual, rather than potential criminals. Fingerprinting especially was used to determine authorship of a crime and to build up archives where the state could observe criminal careers of individuals retrospectively. In the late $20^{\text {th }}$ century, "DNA typing," namely the 
use of DNA samples from crime scenes to identify authors of crime, came to replace fingerprinting as the most reliable forensic method. Cole argues that criminal justice authorities do not adopt criminal identification technologies "solely on technical grounds" (2001, p. 293). As Latour (1986) points out, for the adoption of an innovation such as the use of DNA in criminal justice, the progressiveness and brilliance of the original idea is not sufficient. The project itself needs to be integrated into and resonate with the projects, ideas and intentions of other actors. Thus, translation of DNA technology into criminal justice did not come directly or naturally. Cole explains how unsolved sex crimes provided ample ground for the development and funding of DNA identification techniques in the UK. Sex crimes were appropriate for the DNA typing as aggressors often left blood or semen in the crime scene, from which their DNA could be obtained. However, Cole implies that technical suitability was not the only reason for the adoption of this technology; the significance given to sex crimes in popular culture also prepared the ground for its adoption by authorities.

This "model" of adoption is also relevant for the Turkish case. Although sex crimes were technically and socially more relevant to DNA typing in the West, in Turkey crimes presumed to be political provided the spring board for the adoption of this technology. The category of "unsolved assassinations" (faili meçhuller) was similar to that of sex crimes in Western nations in terms of the concern it created in the society. This category of crime was usually understood as politically motivated assassinations of high profile individuals, including journalists, academics, politicians, intelligence and security officers. Thus the utility of DNA typing was initially demonstrated in high profile homicides, rather than sex crimes. One such crime that popularized this 
technology in the criminal justice community was the killing of the prominent businessperson Üzeyir Garih, a Turkish Jew, in 2001 (anonymous public prosecutor, personal communication, July 1,2007$)$. This homicide was initially thought to be such an "unsolved assassination." 101 A 13-year-old child was initially exposed as the suspect, detained two times and allegedly tortured in detention (Gurol \& Seref, 2001). Another suspect was ultimately identified as the killer with the use of DNA technology, prompting the forensic experts and police officials to propound the utility of this technology.

The twinning project sought to harness this technology to the political objective of accession of Turkey to the EU. As expressed in the twinning fiche, use of scientific investigation techniques "would result in more robust and transparent investigations that would increase the likelihood of convicting the guilty whilst protecting the liberty of the innocent" ("Strengthening forensic capacity," 2003, p. 3). The assumptions that this project relies on can be summarized as thus: One of the problems with the law enforcement agencies in Turkey is the use of illegal methods in the investigation of crime, especially torture and ill treatment. Law enforcement agencies have resorted to detention as both a means of punishment and an element of investigation of crimes. Intimidation of suspects and forcing confessions was seen as a useful way of investigating crimes although many suspects denied the statements they gave in police stations once they came in front of a judge. The pressure exerted by the superiors on the officers to produce suspects and solve crimes has led them to use primitive methods like

\footnotetext{
${ }^{101}$ Various conspiracy theories were circulated at the time of this homicide, some implying that this was a political crime aiming to destabilize the government by showing that it could not control radical Islam. There were claims that a bag with the word Allah (God) written on it were found at the site of crime, and that Israeli intelligence had warned Turkish authorities about potential attacks on Turkish Jews (Hürriyet, 2001a). These theories were later discredited by the court's verdict.
} 
torture. As one EU official involved in the project has indicated, "in the past the police had resorted to torture because they did not know any other methods" (personal communication, June 19, 2007). According to this understanding, torture and ill treatment were not corollaries of a state of exception, as Agamben would argue. It was not based on an ideology; indeed, in this discourse torture appeared as a makeshift device used when the police failed. It was not a conspiracy but a desperate attempt. Thus, this project implies and operates on the basis of the notion that violence is the basic tool that is used when nothing else is on hand, and hence the police resort to ill treatment when the normal resources that should be available are not.

This logic is far different from the accusatory strategy that Turkish activists have propounded in order to understand and explain torture since the 1970s. As we have seen in Chapter 2, many human rights advocates have traditionally seen torture as one of the instruments in the repertoire of the state, which frequently resorts to violent tactics to ensure its survival in the face of social opposition. For instance, the Democratic Resistance of Turkey, a self-exiled opposition group, wrote that the 1971 military intervention and the ensuing repression and state violence aimed to quell the rising tide of social opposition. When the resistance of democratic and leftist groups, intellectuals, and others reached a critical point with the help of economic crisis, the army intervened to secure the political regime. Subsequently, mass arrests, trials at military tribunals, death sentences, and finally torture were used to quash political opposition (Democratic Resistance of Turkey, 1972, pp. xi-xii). The torture was perpetrated by a powerful state, which saw no limits to its action set by society. A similar notion can also be found in scholarly studies. As a Turkish scholar argued, lack of a landed aristocracy in the 
Ottoman Empire and the liquidation of the Greek and Armenian bourgeoisie have prompted the development of a state structure that was independent of the social classes in the society, which were already weak (Keyder, 1979). The weak Turkish bourgeoisie could not act as a limit on state action making possible arbitrary conduct. According to another human rights activist, this situation defined Turkish politics well into the 1990s (Anar, 2000). In line with this, the president of the Turkish Human Rights Foundation had argued that "torture clearly expresses and symbolizes the September 12 regime and its mentality that goes on today" (Turkiye Insan Haklari Vakfi, 1996). Briefly put, torture was identified with the state and its excessive power.

The twinning project's conception of torture once again relieved the state of direct responsibility as torture was seen as something that the police resorted to in order to achieve its legal duty of combating crime. In this rendering, torture and ill treatment are seen as what criminologists call the "noble cause corruption," the use of wrong means to achieve right ends by the police (Kleinig, 2002). In Chapter 1, I had shown how the Turkish government distanced itself from the misconduct of the police in the analysis of Turkey's National Program. In the twinning project, the state was similarly understood in liberal terms, as a political authority that aimed to serve the citizenry. In line with the preventive strategy, political violence in the form of torture was due to incompetence of its agents, but was ultimately an aberration that occurred in the process of provision of security. If the capacity and capabilities in the form of forensic techniques, laboratories, and the knowledge to handle crime scenes were developed in Turkey, these problems could be overcome. This framing of torture by the twinning project is reminiscent of what happened to anti-racism when it was appropriated by the state in Britain. As Lentin 
argues, when concerns of race and racial discrimination were taken on by the state, they were translated into a largely cultural problem devoid of socio-economic aspects and produced a body of "race professionals" seeking to defuse racism (Lentin, 2008, p. 324). In a similar way, professionals of good governance rendered torture a question for which the government was not directly (and criminally) responsible but was obliged to eradicate.

The twinning initiative with its documents such as project fiches are similar to what Asdal (2008) has labeled "little tools of democracy," 102 mundane but effective instruments that reframed and recontextualized problems such as ill treatment of citizens. Asdal has coined this term in relation to her study on governance of pollution in Norway. She tells the story of how a public administration board designed to decide on the applications for constructing new power plants normally operating within the frames of a national economy, energy security and costs to industry was challenged with new reports of expertise. These reports reframed the problem as a question of acid rain, evolving technologies of energy, and recontextualized it as an international and European issue. My point is not that twinning fiches democratized the process of police reform in Turkey but to underline the agency of mundane tools such as documents, charts, reports. In a similar fashion, project fiches were crucial in reframing the problem of ill treatment as

\footnotetext{
${ }^{102}$ Asdal is employing the term democracy in a specific Latourian sense. Democracy, as it is used by Asdal, is not necessarily about the sovereignty of the people or participation in decisions through political parties and elections. Latour develops what he calls an "object-oriented democracy" where the stability of things is interrogated, and the necessity of participation and co-operation of different parties in the construction of objects is exposed (Latour, 2005).
} 
one of securing convictions and improving the justice function of state, rather than coming to terms with a patrimonial bureaucracy or state crimes. ${ }^{103}$

Twinning experts depicted torture as an exigency, rather than as an instrument adopted by the state to maintain power in the face of social and political challenges. According to the project fiche, "integration of scientific evidence into policing practices in Turkey will drive a move from confession-based investigation strategies to one founded on physical and scientific evidence" ("Strengthening forensic capacity," 2003, p. 3). This scientific shift, it was hoped, would bring benefits both to the Turkish population and the European Union. It would help the judicial system better differentiate the guilty from the innocent, and prevent unnecessary lags in the system by doing away with the problem of retracted confessions. Besides these boosts to the image of judicial system nationally, improved use of forensic services would also help fight with transnational crime.

Forensic science methods have long been in use by the Turkish police. A criminalistics lab was established in 1938 , and a department responsible for criminal evidence analysis was formed in late 1970s (Emniyet Genel Mudurlugu, n.d.). Since 1993, crime scene investigation training is being provided to the members of the profession ("Strengthening forensic capacity," 2003). Therefore, the Turkish police had some experience in the use of forensic science methods. What the project sought to achieve was the expansion of the use of these methods and their use for other ends. As

\footnotetext{
${ }^{103}$ It is also notable that this focus on mundane tools of reform is shared by the European Commission itself. In a pamphlet on twinning, the Commission put a chart with the title "Who Does What? Who are the Stakeholders?" The chart includes 4 stakeholders/doers: the European Commission, the Member State, the Beneficiary Country and the Twinning Project Fiche/Contract/Work Plan and Budget (European Commission, 2006b, p. 10).
} 
explained in the previous chapter, in late 1990s the use of methods such as phone tapping and secret agents tended to expand in part due to the Susurluk incident, which exposed the long hand of criminal organizations in the country. The twinning project built upon the catchphrase of "getting at the criminal through evidence rather than getting at the evidence through the criminal" (Hurriyet, 1999) promoted by the then Minister of Interior Tantan in his fight against organized crime. This phrase referred to the extraction of confessions from suspects as the preferred and traditional method of gathering evidence and called for its replacement by scientific methods, which were seen as foolproof and better suited for the fight against organized crime. The twinning project sought to reinforce this emphasis on evidence gathering by making crime scene investigation techniques more widely available. The police would look for criminal evidence from the crime scene rather than interrogating suspects.

This shift towards scientification of police work required a series of initiatives that were listed in the project fiche. The Turkish police required first response officers who were trained to collect evidence from a scene, labs to analyze this evidence in a standardized way that would be transferable, quality management systems to manage labs, build a National DNA database, and senior management with sufficient knowledge to guide investigations towards scientific methods ("Strengthening forensic capacity," 2003).

In terms of the effects, this twinning project contributed to the restoration of the public confidence in the police organization. By expanding the use of scientific methods, the police could solve more crimes including some "cold cases." The media, used to criticizing the police organization for its corruption now pointed in awe to the 
organization's scientific capabilities in throwing light on very complex crimes. A case in point was media reporting on a crime solved by police officers in Konya, a central Anatolian city, by analyzing evidence such as tiny pieces of a wooden stick. The police work was reflected as reminiscent of the TV show "CSI Miami" which was highly popular in Turkey (Aydin, 2006). The reporter dubbed the events as "CSI Konya," improving the credibility of the police with reference to scientific authority and signaling a change in the police department toward being more "technological." This happens through the redefinition of the place of crime as "crime scene" and the first police officers to arrive at the scene as "first response officers." This construction can clearly be seen in a "first response team guide" published by the Criminal Laboratories Department of the police organization (Emniyet Genel Mudurlugu, 2006). This pocket guide separated the process into three phases: notification of an event, travel to the scene and arrival at the scene; each phase having its own rules and procedures. In each phase, the police officers were ordered to ask certain questions, note down information, carry relevant equipment, and secure themselves, the scene and the passersby. This protocol is far different from the behavior of the police officer who in 2003 checked a suspicious package with a broomstick that he had borrowed from a nearby shopkeeper (Kocaer, 2003). CSI techniques also redefine the body of the suspect. Rather than a body from which a confession can be extracted by means of physical and psychological intimidation, the body and its tiny debris are seen as evidence that can be used against the suspect, and made to talk through scientific analysis.

Another effect of the twinning technology here is the contribution made to the capabilities of the police organization. Human rights standards and the EU membership 
conditions that required respecting them have long been seen as ridding the police of their most necessary powers, by almost paralyzing them and putting the survival of the state in danger. Indeed, liberal institutionalism also contributed to this idea by conceptualizing human rights as constraints on state action. Strengthening the police forensic capacity has had just the opposite effect of greater potential of governmental control on the population by opening up domains that were not previously available to the state. The state could now improve its feature of being a center of calculation by having access to new kinds of information. In addition to the e.g. political tendencies, familial relationships, locations, professions, physical appearances and religious affiliations of the Turkish population, the state could now use forensically analyzable biological and DNA information of bodies. Rather than limiting state power, human rights practices and anti-torture policies expanded the capacity and capabilities of the state and its hold on the population.

\subsubsection{Statement Taking Methods and Rooms}

This scheme was one of the earlier twinning projects between Turkish police EU member states. The twinning covenant was signed in July 2004 between Turkey and Austria and Germany as the partners. The 20 month project envisaged an EU contribution of close to 1.5 million Euros and brought experts associated with the Ludwig Boltzmann Institute of Human Rights in Vienna to Turkey (Delegation of European Commission to Turkey, 2004). Similar to the above projects, this one defined its objective as the consolidation of democratization, respect for human rights and rule of law in Turkey ("Improvement of statement taking," 2002). These political objectives were rendered into technical benchmarks of improvement for statement taking activity and the cooperation 
of certain elements of the judicial system. In this way the twinning technology was translating democracy into concrete, measurable and verifiable indicators.

The project was justified by the EU requirement of compliance with the Copenhagen criteria. Since these do not provide specific guidelines as to how to take statements and build rooms for that purpose, the project fiche borrowed from the recommendations of the Council of Europe's Committee to Prevent Torture. The Turkish government, it was emphasized, had already come a long way towards meeting human rights standards. Yet some problems remained. These problems centered on the physical conditions of the interrogation rooms, the lack of videotape recording of the interrogations, the perception of interrogation as a method for extracting confessions (which presumes guilt) and the unsatisfactory training available to officers tasked with interrogating suspects. The project fiche also implied that the Turkish police relied too much on interrogations rather than other evidences in the investigation of crimes ("Improvement of statement taking," 2002).

The project included three modules: improving the way police took statements from suspects and evaluated and used evidence in this process; defining the standards of statement-taking rooms; and strengthening cooperation and coordination between police, prosecutors and lawyers. The first module aimed to transform the statement taking process by training police trainers in new methods. These methods included deployment of knowledges such as criminal psychology, body language and criminal profiling. An important input in this module was the linking of the statement taking process to other forms of evidence collection, especially crime scene investigation. Authors of the fiche believed that statement taking should not be an independent activity but be developed 
with the evidence from the crime scene. The project proposed a new model of statement taking for the police practioners. To start with, it dropped the term of interrogation and questioning and adopted statement taking and interviews. The former were apparently considered too offensive and presumed the culpability of the persons under custody. As such, it was not appropriate for interviewing victims or witnesses. The new Code of Criminal Proceedings adopted a similar stance by defining the phrase "interrogation" as a practice conducted by the courts, not the police. Moreover, Statement Taking Methods and Human Rights Training Manual (Pritz et al., 2005) produced for and used during the project propounded a new approach towards statement taking, and the truth status of statements obtained in this process. The manual emphasized that information given by the interviewees was based on perceptions, which are subjective, selective and constructive. This meant not only that, statements given by witnesses were not always entirely reliable but also that contradictions in suspect's statements did not necessarily mean he or she was giving a sham statement. Statements should be evaluated in relation to all the evidence available. This devaluation of the statement was also echoed with the introduction of a new Code of Criminal Proceedings which emphasized the collection of material evidence other than confessions (Ozkorul, n.d.). Moreover, this twinning project involved a redefinition of the suspect as a more autonomous individual. A suspect who was supposed to confess his crimes can be seen as a captive of the criminal justice process, who can liberate himself, in a sense, by confessing the crime. The twinning project rendered this suspect free by constructing statement taking as an opportunity, or as a EU twinning expert involved in the project put it, statement taking "is not about getting evidence, but is about confronting the suspect with certain suspicions and giving 
him the opportunity to give a statement" (Karl-Heinz Grundboeck, personal communication, June 7,2007 ). This also meant a debasement of the statement as a source of truth, as the statement became a simple procedure or just the right of the suspect to speak. The evidence from fingerprints, DNA, or tape recordings was already there and incriminating the suspect. Statement taking was turned into an occasion for the suspect to respond to these incriminating facts, almost a rehearsal of the process that he would undergo in front of the judges.

The second module sought to define the standards of statement taking rooms, and to "make durable" (Latour, 1991b) compliance with human rights during statement taking by building 30 rooms in a pilot program to be implemented in different parts of the country. These rooms would feature appropriate lighting, air conditioning, a comfortable chair and table, a mirrored wall as well as digital recording equipment. Indeed, statement rooms would be composed of three rooms: one for statement taking, one for observing the latter, and one for monitoring the process with devices and for storing information. Turkish police and project partners agreed that statement taking rooms would not be in isolated locations, not use spot lights, use chairs of equal size and comfort and refrain from intimidating elements such as upholstered walls (Final report: Improvement of statement, 2005, p. 9).

The third part of the module concerned the relations between police, prosecutors and lawyers. The fiche did not provide much detail on this module save for the point that current level of cooperation between these elements was not satisfactory, negatively affecting the statement taking process. The point was elaborated during the application of the project. Albin Dearing, an expert of human rights law associated with the Ludwig 
Boltzmann Institute and an advisor in the project, explained this concept as the promotion of "team work" between the actors of the criminal proceedings, especially the police and the public prosecutor (Dearing, 2005). As a part of the twinning project, he made presentations to the police and public prosecutors, advising that actors within the criminal justice system should be independent towards both the political authority and other actors in the system. The contradiction of different roles within the system would be beneficial for the attainment of the common goal of justice. Police authority and the judiciary would constitute opposite poles in the system, while the prosecutors would occupy the middle ground. Prosecutors would direct the police in investigations, and they would retain the final say while communicating with the police and taking into consideration their concerns. In this way, the police organization, which had been left to work with its own methods for many years, would be guided by the prosecutor according to the principles of criminal procedure. This would result in better evaluation of evidence and better investigation that could prevent problems in the judicial system.

\subsection{Conclusion}

This chapter has considered the twinning procedure of the EU as an international technology of government or benchmarked harmonization that operated within the context of a preventive strategy. Adopting a Foucaultian perspective that emphasized government as an enterprise involving calculation, expertise, and intrigue instead of regulation or institution-building has allowed a broader perspective into the workings of this instrument. It has been shown that the twinning technology is a composite instrument that borrows from similar technologies used in public management and international development such as performance measurements and capacity building, respectively. I 
have also shown that twinning relied on other tactics such as market rationality or shaping the ethos of subjects to attain its objectives. It has further been shown that twinning technology divides, isolates and translates political activity into manageable chunks of technical work such as the adoption of DNA technologies, statement room architecture. The twinning projects reconstruct political processes by first dividing them into observable and verifiable activities. This has been the case here when twinning projects divided human rights reform into elements such as improvement of statement taking, accountability and forensic capacity. In turn, these activities were further narrowed down into different modules that matched with benchmarks. This compartmentalization of political processes was not only applied to the beneficiary countries. Practices that pertained to human rights reform in member states were also isolated as "best practices." In this way, a series of practices became a package that was mobile, transferable from one location to the other. This has also allowed the project authors to pick certain practices as best examples in terms of complying with human rights and to disregard violations of human rights that took place in the same organizations where the best practices were found. Moreover, twinning functioned as a device of translation. Objectives like democracy, human rights and rule of law were translated into specific projects of improvement of police practices. In this way it has become possible to think that creating statement taking rooms with adequate heating, ventilation and comfortable chairs, and establishing a national DNA database contribute to democratization in a country. Democratization, liberty and the human rights of citizens were not necessarily a problem of norms and values according to this rendering. Rather, it became simply possible to "forget" about many of the problems and allegations of torture 
by concretizing human rights practices in socio-technical artifacts such as rooms and laboratories. In addition to these, the chapter has shown that twinning technology has also been used as a means to enroll actors to the objectives of human rights reform. By design, twinning included procedures of negotiations, consultations and understanding the stakeholders. In relation to this, it has deployed tactics used by the global human rights expert community such as experiential learning.

In terms of its effects, twinning has legitimized and disseminated science, technical knowledge and expertise as means to solve intractable problems like torture and ill treatment. In the process, much like the idea of twinning has prefigured, association with EU and engaging in projects with this supranational organization has come to be seen as a source of legitimacy by some elements of the police organization. It would be wrong to assume that this sentiment (EU=legitimacy) is shared by all sections and ranks of the police. Yet, the emphasis put on twinning shows that cooperation with the EU has certainly become a positive career move for at least some of the members of the profession. 


\section{CONCLUSION}

Since the revelation of torture in 2004 in Iraq and other theaters of the Global War on Terror many authors have focused on the causes and consequences of this practice. Many highlighted the continuities between the use of torture by the French army against the Algerian combatants in the 1950s and American methods in Iraq and Guantanamo Bay. Neil MacMaster, for instance, showed how the counter-insurgency techniques borrowed from the French warfare in North Africa have been used by the US in Vietnam and then in Iraq (MacMaster, 2004). Amid the resurgence of torture, MacMaster invoked Beccaria's tract written during the Enlightenment to point out to the fallacy of torturing suspects to obtain information. Likewise, in a publication in 2004, the Human Rights Watch quoted an Enlightenment philosopher to argue that torture leads to false information (Human Rights Watch, 2004). Similar to the book (Levinson, 2004) that I mentioned in the first page of Chapter 2, these interventions in the problem of torture give an impression of a continuous thread between the Enlightenment and the present struggles against torture.

\section{Multiplicity of Anti-Torture Policies}

In this dissertation I opted for a different perspective on efforts to eradicate torture by foregrounding the multiplicity and complexity of the human rights work. This is not to argue that there are no similarities or continuities between the Enlightenment efforts and modern anti-torture policies. Certainly, the Philosophes helped consolidate the framework of rights as the broader context within which practices of torture were understood. As I have mentioned in Chapter 2, theological discourses also problematized the use of torture and similar exercises of power on the body. However, the 
Enlightenment's secularized framework became dominant in time. The moral language of the Enlightenment was also translated into the language of the $21^{\text {st }}$ century as a significant resource for the development of critiques of violence on human body and soul. The Enlightenment language has not only colored the shaming and naming tactics of human rights advocates but also complemented the policy discourses that regarded torture as a question of bureaucratic incapacity. The moral language of the Enlightenment helped reproduce human rights activism by providing a rationale and an "ideology" for the human rights advocates.

But there have been significant transformations in the anti-torture policies as well. In this dissertation, these changes have been presented at two different levels. On the one hand, I focused on the discourses and practices circulating in global spaces of human rights advocacy. This has entailed an analysis of approaches to torture in the United Nations, Council of Europe, Amnesty International and similar venues. On the other hand, I looked at the ramifications and further mutations of anti-torture policies in the Turkish context. In doing that, I explored the discourses and practices to know and control torture circulating in political and bureaucratic circles.

Perhaps one of the most significant differences between the $18^{\text {th }}$ century and modern anti-torture policies concerns the way torture was known. The writings of authors like Voltaire and Beccaria indicate that they approached torture as something that they already knew; an object that appeared familiar to them through their knowledge of the infamy of the Catholic Church and the reactionary tendencies of the members of what would later be known as the old regime. Voltaire, for instance, was interested in the cases of torture and the events surrounding them to the extent that they helped him construct 
narratives of pain and suffering. He was not interested in the frequency of torture in France or its exact geographical distribution. He was not interested in how "ordinary men" turned into torturers. As I argued in Chapter 2, his activism against torture was based on a hypothetical understanding of torture. We have seen that one of the preconditions of the emergence of strategies against torture was the transformation of the procedures of knowing torture. This was apparent in the way torture was handled in the Madras and New Caledonia scandals. The inquiry method of producing truth by an objective, knowledgeable and impartial authority was applied to incidences of torture in these cases. This was a significant event in the history of anti-torture policies. The deployment of the inquiry in such incidents almost became the norm in countries such as United States and Britain and became established as the "natural" reaction to cases of torture. The knowledge that emerged from these cases, what I called new empirics of torture, sought to capture torture in relation to qualities such as the moral character of torturers, their levels of civilization, their salaries and workloads, functioning of the criminal system, supervision of officers and so on. A further development that formed the basis of later anti-torture strategies was the emergence of international supervision or the migration of high modernist (Scott, 1998) techniques to the international sphere. The contingency and the assembled character of human rights activism are apparent in this development. The techniques of surveillance and "governing at a distance" that would be increasingly utilized in the post-WW2 era were borrowed from the League of Nations. This indicated that techniques of activism were not inherent to human rights struggles but borrowed from elsewhere. The LoN techniques were developed to supervise states and thus were techniques of government. The adoption of these techniques also indicated that 
human rights activism involved the exercise of power, and was not a pure opposition to power as some accounts implied (e.g. Neier, 2003).

The new empirics of torture and the techniques of supervision provided the framework of anti-torture strategies. The analysis has further underlined the multiplicity and complexity of human rights efforts by demonstrating the existence of several strategies against torture. In exploring different strategies, I relied mostly on the contributions of the governmentality perspective. This framework guided the analysis towards the political rationalities and technologies of anti-torture strategies. The interestbased and constructivist theories are mostly interested in the effectiveness of the international human rights regime. Although this is a crucial question, focusing on the effectiveness risks ignoring the differences between human rights strategies. Looking at the type of political authority (state vs. non-state) may not be the only way to grasp these differences. This difference can be also seen by looking at the ways in which torture is conceptualized, at the nature of the objects to be governed and at the subjects prioritized for different tasks. We have seen that in constitutional strategy torture was often conceived as a practice emanating from cruelty and inhumanity. These concepts, in turn, were understood not necessarily as personal and moral qualities but often as tendencies inherent in the history of humanity. This was quite similar to the Enlightenment notion of torture. Nevertheless the proponents of constitutional strategy, as inheritors of the guilt and shame of the mass killings of the WW2 were not as optimist as the Philosophes. The eradication of torture was not imminent but dependent on the mobilization of world public opinion under the leadership of eminent visionaries like Eleanor Roosevelt (in he role as the first chairperson of the UN Commission on Human Rights) or Winston 
Churchill (in his role as one of the founders of Council of Europe). Critical of sovereignty but respectful of the institution of the nation-state, the constitutional strategy saw jurists as its main allies in bringing an end to human rights violations. As can be seen from the CIA funding provided to International Commission of Jurists (Tolley, 1994), the constitutional strategy was implicated with the Western bloc's Cold War policy of undermining Soviet political legitimacy. International and national laws that internalized human rights norms were seen as a powerful mechanism of shaping nation-state behavior. This way of intervention was appropriate for the constitutional strategy for two reasons. First, once human rights norms were embedded in national law, the violations of human rights could be solved without overt international intervention and provide justification for juridical actors within the state. Second, it reduced the need for constant surveillance of nation-states by delegating tasks to the national actors.

The accusatory strategy indicated a further mutation in the problematics of antitorture. Rather than a philosophical conception of torture as found in constitutional strategy, accusatory strategy understood torture as a systemic problem, maintained by the support of Western states to violator states. The Cold War system of alliances underwrote the practice of torture in that Western states often ignored violations taking place in the allied countries. For instance the Amnesty International's technique of adopting prisoners from both the Western and Eastern bloc (Power, 1981) aimed to counter the perception that violations were confined to the "other bloc." Systematicity of torture was also apparent in the trade in implements of torture and transfer torture know-how through military training (Amnesty International, 2001). This notion of torture was not only related to the international sphere. As the dissemination of concepts such as "government 
by torture" (Rosenbaum, 1975) and "administrative practice" (Hannum \& Boyle, 1977) indicated, the links between different actors and regularity increasingly characterized the way torture was understood in this strategy. A significant shift in the anti-policy of torture was seen in the subjects of this strategy. As opposed to the "elitist" (Dezalay \& Garth, 2006) attitude of the previous human rights efforts, accusatory strategy chose to construct and mobilize publics through campaigns, letter writing, etc. The pressure of "the public opinion" was necessary to engender a "political will" that respected human rights norms. With its emphasis on urgency and immediacy, the preventive strategy differed from previous efforts. It deployed its capacity of surveillance of the world not only to alert local Amnesty groups but also political leaderships that were seen as responsible. In the preventive strategy, appeals to statespersons co-existed with an approach that emphasized the punishment and exclusion of responsible state actors, thereby shedding the respect for "national sentiment."

Another shift in the problematics of anti-torture was registered with the rise of preventive strategy. In this strategy, the concern was not exactly the moral character of the torturers or their inclination towards cruelty. Torture was not understood as a conspiracy that was made possible through the secret undertakings of states. The international system was less relevant. These new truths regarding torture was made possible through a conception of this practice as a problem of state (in)capacity. Torture was often due to habits and professional culture of the law enforcement officers who had to resort to inefficient (and perhaps labor-intensive) methods of crime investigation. In this context, the objective of the strategy was prevention of torture by cooperating with states and building up their crime investigation capacity. This technicalized strategy used 
shaming tactics rarely and assigned the task of prevention to human rights and policing experts. The main task of these experts was not to persuade the law enforcement officers to behave according to human rights norms by internalizing them but opening up new routes for them to accomplish their tasks without violating human rights.

\section{The Question of Torture in Turkey}

After the exploration of different strategies, the dissertation turned to an analysis of the problem of torture in Turkey. We have seen that all three strategies had ramifications for the politics of human rights in Turkey, although the accusatory and preventive strategies have been more pronounced in our analysis. In line with the argument on multiplicity of human rights struggles, I have shown that torture has been problematized in different ways from the 1970s on. The constitutional strategy was rendered redundant due to the rise of political opposition movement in the 1960s. With the adoption of national security doctrine as a guiding set of ideas in the government of the state and the society, achieving an order based on human rights was deferred. The accusatory strategy emerged after the 1971 military intervention leading to a conceptualization of torture as cruelty and state crime. From the late-1980s on, a new thinking regarding torture emerged. This new thinking emphasized the development of the country and improvement of the state apparatus and conceived torture less as a problem of the moral and psychological properties of the police officers. This made possible the introduction of preventive strategies against torture in Turkey. This strategy, supported by both domestic and international actors, institutionalized the idea that torture was due to lack of capacity of the police. 
In exploring the problematics of torture in Turkey in terms of the strategies, we have also seen that the advance of preventive strategy was made possible by transformations in police identity and internal struggles within the field of security. The preventive strategy's support for the improvement of police capacities has created the conditions for the adoption of human rights initiatives. The analysis has also shown that when human rights were adopted by state actors, they were transformed in a way that would fit their own interests. The political criteria for EU membership have been pegged to the improvement of the working conditions of police officers, for instance. In parallel with Latour's (1986) Actor-Network theory, this analysis has also shown that human rights reform does not have an inherent power to disseminate, it has to be taken up by others who mold it for their own ends. Moreover, this analysis included actors other than the state elites and "civil society" into the picture. Studies of socialization and social learning have often focused on these actors as conveyors of norms. Yet, entities like police departments can also assert themselves as actors in the construction of orders. The focus on the twinning projects in Turkey has further indicated the relevance of the analytics of strategies. What were advocated and disseminated in these projects were not general norms about human rights and democratic policing. These concepts were put into practice in specific ways that reflected the evolution of human rights strategies. As seen

in Chapter 5, the focus was not necessarily on turning police into human rights actors but into more efficient crime fighters who would not violate human rights.

\section{The Implications for Culturalist Approach to Human Rights}

The preceding analysis has several implications for the culturalist approach to human rights. To begin with, theories that emphasize interests of Great Powers (such as 
David Chandler) are too general for understanding anti-torture policies. The shift towards preventive strategies, for instance, is difficult to explain in terms of the national interests of the Great Powers. Not only states like United States did not, as a national entity, participate in or dominate the formulation of this strategy but arguably its interests can accommodate both constitutional and preventive strategies leaving the national interest with little explanatory power. The shift has taken place mostly through the internal processes of human rights activism. The dissertation has also shown that anti-torture policies do not necessarily decrease state capacity for action. Therefore, conceptualization of human rights policies as ultimate limits on state sovereignty (Krasner, 1993) is not necessarily the best way to capture them. As seen in the twinning projects in Turkey, reforms can actually expand state power by adding certain capabilities (DNA typing, new methods in crime investigation) to it.

A second body of culturalist appraoch that this dissertation tackled was constructivism. I have pointed out in the introduction that constructivism has made significant contributions to the study of human rights by underlining the importance of ideas and norms in politics. Foucault himself focused on ideas and norms to understand the ways in which populations were governed (especially Foucault, 1979), although his conception was different. One of the points that constructivist analysis of human rights made was that norms and ideational structures exert significant influences on state behavior (Wendt, 1995a). Without contradicting this thesis, I have tried to show that norms are very practical things that influence the conduct of actors through certain technologies. That technology had a significant effect on human agency has almost become the mainstream in the extant analyzes of revolution in the Arab world. Pundits, 
journalists and others emphasize how internet services like Facebook and Twitter were functional in bringing about the end of decades long non-democratic regimes (Lynch, 2011). Others charge that communication has always been part of the revolutions. French Revolution would not be possible without journals and pamphlets, they say, so nothing new here (Reymond, 2011). Certainly allocating too much explanatory power to the internet would be fallacy. However, I think that this discussion underlines the growing recognition of mundane tools like pamphlets and computers in the conduct of politics. Yet we should also recognize that these devices not only enable action but also shape it. In line with this, I have demonstrated how a technology like DNA typing not only enabled the investigation of crimes but it has also encouraged the police to pursue forensic evidence rather than confessions.

Another criticism that can be directed against constructivism is its inadequate perspective on agency. This may sound as counter-intuitive given that many constructivists are eager to show that non-state actors like NGOs and "moral entrepreneurs" are able to influence state behavior by associating with other actors (Sikkink, 1993). Yet the agency I am referring here is not about the advocacy networks or international organizations that promote human rights. As I tried to emphasize in Chapter 5, those that are at the receiving end of the human rights norms also exercise agency. My point inspired by sociology of translation (Callon, 1986; Latour, 1986) was that for the promoters of the anti-policies to be successful they need to create projects that can be consented or subscribed to by others. Constructivists often focused on the work of promoters and followed them in their endeavors to convince others (Checkel, 2001). Some have tried to explain the success of norms by not looking at those receiving them 
but by looking at the attractiveness of the promoters, such as European Union (Manners, 2002). Especially in the context of preventive strategies my emphasis on translation has shown that promoters of norms or contenders need to cater to the interests of actors who are asked to adopt a certain project.

\section{The Future of Anti-Torture Policies}

At the beginning of the $21^{\text {st }}$ century, what can we say about the scene of antitorture policies? Is it possible to detect certain tendencies that become dominant over others? We can only provide some preliminary answers to these questions. When we look at the field of human rights, it is possible to detect that the work of human rights is increasingly being professionalized, institutionalized and associated with corporate actors such as states and international organizations (cf. Barnett, 2005). ${ }^{104}$ The preventive strategy, with its emphasis on expertise, seems to accelerate and intensify this tendency. This strategy requires the monitoring of the field, accumulation of expertise, and experts that will actually help implement the programs of improvement. These processes in turn are carried out in cooperation with international organizations and states. When we look at these conditions, it becomes clear that the preventive strategy opts for a professionalized human rights work. Monitoring, development of programs of reform, etc. are technical tasks which cannot be carried out by the occasional human rights activist. The states and international organizations, in turn, require institutionalized partners with whom they can negotiate, make contracts and develop projects with clear benchmarks. The shift of responsibilities of the state to communities and NGOs in

\footnotetext{
${ }^{104}$ Barnett defines professionalization as the development of professional doctrines, specialized areas of training and career paths whereas institutionalization is defined as the multiplication of agencies and relations between them, maintenance of standard operating procedures, and experienced staff with technical knowledge (Barnett, 2005, p. 725).
} 
advanced liberalism (Rose, 1999b) has favored a model of human rights activism that includes not only shaming but also, and perhaps more significantly, monitoring, collection of information regarding violations and the provision of services. The recent grant to the Association for the Prevention of Torture eligibility for Official Development Aid can be read in this light (Association for the Prevention of Torture, 2011). More than three decades after Gautier's (1979) article calling for a shift towards preventive methods, capacity building programs have become the main recipe for solving human rights problems like torture. The multiplication of twinning programs around Europe (European Commission, 2011) suggests the provision of technical expertise on the basis of contract is becoming the dominant method to solve problems of human rights.

Besides the shift in strategies, we can also observe certain changes in the geopolitics of torture. The survey of anti-torture strategies demonstrated how these have been implicated with the Great Power politics. Geopolitical projects to shape Eastern Europe were very much related to the rise of the notion of minority rights after the WW1. These rights were seen as an instrument of geopolitical stability in the area. In the aftermath of the WW2, human rights itself has become part of the politics of new international order. These values were included in not only the UN Charter but also become a cornerstone of a new political consensus with the adoption of UDHR in 1948. The constitutional strategy reflected the effort to build upon this consensus and disseminate it through judicial means. The authors of this strategy saw it especially relevant for countries where fascism and similar ideologies gained a significant popularity. It was thought that a constitutional strategy could help sustain democratic orders thereby preventing human rights violations. 
The politics of Cold War was a significant challenge for the promotion of human rights. Both the Western and Eastern blocs came to wage their ideological battles on the human rights ground but this often meant that the individual members of the blocs were spared criticism and diplomatic quarrels between the blocs spiraled into wars of propaganda. In this context, allegations of torture became a valuable stake for the West in its attacks on the Soviet Union. The United States' opposition to torture with shaming tactics was parts of its ideological combat against communism. The US congress invited Soviet and Eastern European refugees and the media to hear their testimonies of repression and torture (e.g. New York Times, 1956). The US opposed the admission of People's Republic of China to the United Nations by highlighting human rights violations, including torture (New York Times, 1959). While the allies deserved the cooperative spirit and benefit of the doubt, the geopolitical adversaries were targeted with public campaigns. ${ }^{105}$ But these tactics were most consistently utilized by the activists of the accusatory strategy, such as Amnesty International. The AI was careful to apply its anti-torture strategies globally, while exposing the support by the advanced capitalist states to less prominent members of the Western camp in upholding the national security state. While this strategy recognized differences between the torture of detainees in Northern Ireland and political prisoners in Greece under the "Regime of the Colonels," in principle, shaming and naming tactics were applicable to all cases of torture and ill treatment. The preventive strategy was more differentiated and was often reserved for

\footnotetext{
105 Jeane Kirkpatrick's 1979 essay on US foreign policy towards dictatorships (Kirkpatrick, 1979) can be seen as an extension of this attitude. Kirkpatrick, who later became US ambassador to the United Nations under the Reagan administration, argued that traditional authoritarian dictatorships such as Brazil, Argentine and Chile were more likely to democratize than revolutionary dictatorships like Cuba or Nicaragua. Therefore, the "traditional dictatorships" deserved the cooperation and support of Washington who could help them transform slowly and through interaction rather than confrontation.
} 
countries which exhibited a certain tendency to become democratic. In a sense, accusatory and preventive strategies came to be reserved for different parts of the world. After the end of the Cold War, if there were sufficient links and rapport with a country where torture has emerged as a problem, it was likely that preventive strategy would be deployed against violations. For instance, in response to the cases of torture and ill treatment in Armenia, Azerbaijan, Georgia, Moldova and Ukraine; the Council of Europe and the EU instituted a project in 2009 with the overall objective of developing "national capacities for combating ill-treatment by law enforcement agencies and investigative institutions, including strengthening the effectiveness of investigations of allegations of ill-treatment" (Council of Europe, 2009). In countries where the "political will" to overcome violations of human rights is absent and the regime is decidedly illiberal, accusatory strategy is seen as more appropriate. Belarus, often dubbed the "last dictatorship of Europe," has appeared on the map of the accusatory strategy especially after the crackdown on the opposition activists and leaders prior to the 2006 and 2011 elections. Tactics such as shaming, condemnation and isolation have been suggested so for this country. In this vein, the European Parliament "condemn[ed] the use of torture against political opponents" and called for consideration of economic sanctions in 2011 (European Parliament, 2011).

The political will of the governments and character of the regime (liberal vs. illiberal) are significant markers of the geopolitics of anti-torture policies. However, even when the regime is liberal, human rights activists can opt for an accusatory strategy that emphasizes criminal investigations, punishment and eradication of impunity. This is apparent especially in the torture cases seen after the authorization of "harsh 
interrogation" methods. Since torture and ill treatment of detainees were a deliberate policy, the improvement of capacity-building programs and prevention through training are not meaningful options in this case. Thus, human rights NGOs like the Human Rights Watch (Human Rights Watch, 2011) choose to press for independent investigations and, if evidence warrants, punishment of wrongdoers including those who were responsible for authorizing the use of illegal methods.

As argued in Chapter 2, one of the hallmarks of the preventive strategy was its avoidance of confrontation with the state and the police and that it operated in a more cooperative fashion, in distinction to accusatory strategy that emphasized shaming and combating impunity. Looking at this aspect only can also give us clues about the global tendencies in anti-policies. Recent studies suggest that some Turkish human rights NGOs working on civil rights issues (e.g. TIHV and IHD) still do not enjoy a cooperative relationship with the state actors. As Cali argues (2007) the tradition of viewing human rights NGOs with suspicion as "potential outlaws" (p. 232) is still influential on the state actors in Turkey. But it should also be pointed out that there is emerging a new strand of human rights activists (not necessarily working on the torture question) who adopt a more cooperative attitude towards the state. For instance CISST (Ceza Infaz Sisteminde Sivil Toplum Dernegi) (Metin, 2011), a recently established NGO working on criminal justice issues such as the monitoring of prisons and rehabilitation of ex-inmates has adopted a more cooperative attitude based on "getting things done" rather than only denouncing human rights violations. For this purpose, the CISST cooperates with the prison authorities to develop schemes to improve the conditions of prisons and reducing prison population. 
Latin American countries like Brazil and Argentina have been countries where significant efforts to reform the security establishments have been made especially in the last decades. Unlike Turkey, the politics of apology and retribution have been potent in these countries, lending support to the agendas of accountability and combating impunity. However, the police reforms in Brazil also carry echoes from the preventive strategy. As Leeds (2007) argues, new generation human rights activists enter into cooperative arrangements with the police to improve human rights. For instance an NGO, GAJOP, established programs to train the police in human rights in a dialogical spirit similar to the one we have seen in EU's twinning projects in Turkey. 


\section{Reference List}

A. T-S. (1959). Reign of the cop. Africa Today, 6(4), 15-16.

Abensour, M. (2008). Persistent utopia. Constellations, 15(3), 406-421.

About OSI staff: Aryeh Neier. (n.d.). Retrieved December 30, 2010, from http://www.soros.org/about/bios/staff/aryeh-neier

Abrams, E. (1984, August 10). The myopia of human rights advocates. New York Times, p. 25.

Acar, E. (2004, February 23). Polisin yitik kusagi [the lost generation of the police]. Retrieved December 5, 2009, from http://www.aksiyon.com.tr/aksiyon/haber9822-34-polisin-yitik-kusagi.html

Adalet Bakanligi. (2007). Soru onergesi cevabi [reply to written parliamentary question]. Retrieved April 19, 2011, from http://www2.tbmm.gov.tr/d22/7/7-21793c.pdf

Adalet Bakanligi. (n.d.-a). Ceza muhakemeleri usulü kanunu (mülga). Retrieved February 1, 2010, from http://www.ceza-bb.adalet.gov.tr/mevzuat/1412.htm

Adalet Bakanligi. (n.d.-b). Emniyet orgutu disiplin tuzugu [security organization discipline regulations]. Retrieved January 5, 2011, from http://www.mevzuat.adalet.gov.tr/html/5124.html

Agamben, G. (1998). Homo sacer: Sovereign power and bare life (D. Heller-Roazen, Trans.). Stanford: Stanford University Press.

Agamben, G. (2005). State of exception (K. Attell, Trans.). Chicago: University of Chicago Press.

Agar, M. (1995). Acilis konusmalari [opening speeches]. In M. Terzioglu (Ed.), Polis akademisi seminer konferans sempozyum bildiriler dizisi (pp. 3-6). Ankara: Emniyet Genel Mudurlugu.

Agnew, J. (1998). Geopolitics: Re-visioning world politics. London: Routledge.

Ahmad, F. (1993). The making of modern Turkey. London: Routledge.

Ahmad, F. (2003). Turkey: The quest for identity. Oxford: Oneworld.

Akarcali, B. (n.d.). 24 yillik bas agrimiz: Insan haklari [human rights: Our headache of 24 years]. Retrieved December 5, 2010, from http://www.bulentakarcali.com/mkl 184 24-yillik-bas-agrimiz-insan-haklari.html

Aksener, M., \& Duzel, N. (2003, 15 September). Interview with Meral Aksener. Retrieved January 5, 2011, from http://www.radikal.com.tr/haber.php?haberno $=88779$

Alderson, K. (2001). Making sense of state socialization. Review of International Studies, 27(3), 415-433.

Alexander, Y., Brenner, E. H., \& Krause, S. T. (2008). Turkey: Terrorism, civil rights and the European Union. New York: Routledge.

Altinay, A. G. (2001). Making citizens, making soldiers: Military service, gender and national identity in Turkey. Unpublished Ph.D. Dissertation, Duke University, North Carolina.

Altintas, N. (2003). Polis; halkin mutlulugu için kendi huzurundan fedakarlik yapmayi meslek haline getiren kisidir [police officer sacrifices his personal peace for the 
sake of the happiness of the people and makes this his profession]. Cagin Polisi, $16,16$.

Altunisik, M. B., \& Tur, O. (2005). Turkey challenges of continuity and change. New York: Routledge.

Amnesty International. (1973). Report on torture. London: Duckworth in association with Amnesty International Publications.

Amnesty International. (1980). Torture in Turkey (No. 44/05/80). London: Amnesty International.

Amnesty International. (1984). Torture in the eighties. Oxford: Robertson.

Amnesty International. (1988). Turkey. Amnesty International briefing (No.

EUR/44/65/88). London: Amnesty International.

Amnesty International. (1995). Turkey: Six deaths in custody in 10 days - Amnesty

International sends delegation to investigate (No. EUR/44/05/96).

Amnesty International. (2000). Turkey: Torture, a major concern in 1999. London:

Amnesty International.

Amnesty International. (2001). Stopping the torture trade. Retrieved July 21, 2011, from http://www.amnesty.org/en/library/asset/ACT40/002/2001/en/8de67fb8-dc5f11dd-bce7-11be3666d687/act400022001en.pdf

Amnesty International. (2007a). Spain: Adding insult to injury. The effective impunity of police officers in cases of torture and other ill-treatment (No. EUR 41/006/2007). London: Amnesty International.

Amnesty International. (2007b). Turkey: The entrenched culture of impunity must end (No. EUR 44/008/2007). London: Amnesty International.

Amnesty International. (2009). Spain: Adding insult to injury. Police impunity two years on (No. EUR 41/010/2009). London: Amnesty International.

Amnesty International USA. (2011a). How it started. Retrieved May 2, 2011, from http://www.amnestyusa.org/individuals-at-risk/urgent-action-network/how-itstarted/page.do?id $=1108056$

Amnesty International USA. (2011b). Urgent action network. Retrieved May 2, 2011, from http://www.amnestyusa.org/individuals-at-risk/urgent-action-network/aboutthe-urgent-action-network/page.do?id=1108053

Anar, E. (2000). Insan haklari tarihi [history of human rights] (2nd ed.). Istanbul: Civiyazilari.

Anayasa Mahkemesi. (1963). Anayasa mahkemesi karar no: 1963/179. Retrieved 4 October, 2010, from http://www.anayasa.gov.tr/files/others/kararlar.rar/62-66.rar

Anghie, A. (2004). Imperialism, sovereignty, and the making of international law. Cambridge, UK: Cambridge University Press.

Archer, C. (2001). International organizations (Third ed.). London: Routledge.

Asad, T. (1996). On torture, or cruel, inhuman, and degrading treatment. Social Research, 63(4), 1081-1109.

Asdal, K. (2008). On politics and the little tools of democracy: A down-to-earth approach. Distinktion, 16, 11-26.

Ashenden, S. (1996). Reflexive governance and child sexual abuse: Liberal welfare rationality and the Cleveland inquiry. Economy and Society, 25(1), 64-88. 
Ashford, N. (1973, August 29). Dossier indicts Turkey over political detainees' torture. The Times, p. 6.

Ashforth, A. (1990). Reckoning schemes of legitimation: On commissions of inquiry as power/knowledge forms. Journal of Historical Sociology, 3(1), 1-22.

Askvik, S. (1999). Twinning in Norwegian development assistance: A response to Jones and Blunt. Public Administration \& Development, 19(4), 403-408.

Association for the Prevention of Torture. (2007). Letting in the light: 30 years of torture prevention. Geneva: Association for the Prevention of Torture.

Association for the Prevention of Torture. (2011, July 10). Apt is eligible for official development aid. Retrieved July 21, 2011, from http://apt.ch/index.php?option=com k2\&view=item\&id=1102\%3Aapt-is-eligiblefor-official-development-aid\&lang=en

Ates, H. (2010, July 14). Istismar alani daralinca PKK azdi [PKK enraged due to lack of abuses]. Retrieved February 17, 2011, from http://www.sabah.com.tr/Gundem/2010/07/14/istismar alani daralinca pkk azdi

Autesserre, S. (2009). Hobbes and the Congo: Frames, local violence, and international intervention. International Organization, 63(2), 249-280.

Ayasili, M. (2005). Emniyet teskilatinda terfi sistemi ve yasanan sorunlar [promotion system in the police organizatin and problems in promotions]. Unpublished Master's Thesis, Polis Akademisi, Ankara.

Aybay, R. (2002). Turkey's declaration of war on Japan at the end of the Second World War. The Turkish Yearbook of International Relations / Milletlerarasi Münasebetler Türk Yilligi, 33, 293-298.

Aydemir, E. (2008, September 29). Memleketimizde militarizmin egemenligi maalesef hala sürüyor...[interview: Militarism still rules in our country]. Retrieved February 1, 2010, from http://www.sesonline.net/php/genel sayfa.php?KartNo=52138

Aydin, A. H. (1998). Insan haklari açisindan polisin güç kullanma yetkisinin mesruiyeti [the legitimacy of police use of force from human rights perspective]. In I. Cerrah \& E. Semiz (Eds.), 21. Yuzyilda polis: Temel sorunlar, cagdas yaklasimlar [police in the 21st century: Basic problems, modern approaches] (pp. 103-130). Ankara: Emniyet Genel Mudurlugu Asayis Daire Baskanligi.

Aydin, G. (1997a, September 8). CMUK polise ceki duzen verdi [procedural law puts the police in order]. Retrieved March 5, 2010, from http://arama.hurriyet.com.tr/arsivnews.aspx?id $=-263390$

Aydin, G. (1997b, September 11). Suçsuz teröristler! [guiltless terrorists!]. Retrieved March 5, 2010, from http://webarsiv.hurriyet.com.tr/1997/09/11/9256.asp

Aydin, G. (2006, December 24). CSI Konya. Retrieved December 2, 2009, from http://hurarsiv.hurriyet.com.tr/goster/ShowNew.aspx?id=5664859

Aydin, S. (2009, June 29). Basbakan: Polis rejimin guvencesi [PM: Police, guarantee of the regime]. Retrieved November 1, 2010, from http://www.milliyet.com.tr/Siyaset/HaberDetay.aspx?aType=HaberDetay\&Kateg oriID=4\&ArticleID=1111566\&Date=28.06.2009\&b=Basbakan:\%20Polis\%20reji min\%20guvencesi 
Azak, U., \& Terzioglu, M. (Eds.). (1995). I. Polis halk isbirligi sempozyumu [symposium on cooperation between the police and the public]. Ankara: Emniyet Genel Mudurlugu.

Bae, S. (2008). Friends do not let friends execute: The Council of Europe and the international campaign to abolish the death penalty. International Politics, 45(2), 129-145.

Bailey, D., \& De Propris, L. (2004). A bridge too phare? EU pre-accession aid and capacity-building in the candidate countries. JCMS: Journal of Common Market Studies, 42(1), 77-98.

Bal, I., \& Beren, F. (2003). Polis etigi [police ethics]. Ankara: Siyasal kitabevi.

Balta, I. (2008, December 2). Gazeteciye kötü haber; polis telsizle haberlesmeyi birakti [police stops communicating with radio]. Retrieved January 8, 2011, from http://www.zaman.com.tr/haber.do?haberno $=766343$

Barnett, M. (2005). Humanitarianism transformed. Perspectives on Politics, 3(4), 723740.

Barry, A. (2001). Political machines: Governing a technological society. London and New York: Athlone Press.

Basbakan Insan Haklari Basmüsavirligi. (1996). Insan haklari yüksek danisma kurulunun 1995 yili çalismalari [studies by high advisory Council for human rights, 1995]. Ankara: Basbakan Insan Haklari Basmüsavirligi.

Beales, D. (2005). Enlightenment and reform in 18th-century Europe. New York: I.B. Tauris.

Beccaria, C. (1764/2008). On crimes and punishments and other writings (A. Thomas \& J. Parzen, Trans. Aaron Thomas ed.). Toronto: University of Toronto Press.

Becket, J. (1972, August 4). Torture as an institution. New York Times, p. 31.

Bell, A. (1995, July 1). Turkish general attacks democracy reforms. Retrieved February 22, 2010, from http://www.factiva.com

Ben-Eliezer, U. (1997). Rethinking the civil-military relations paradigm. Comparative Political Studies, 30(3), 356-374.

Benenson, P. (1961). The forgotten prisoners. Retrieved May 2, 2011, from http://www.amnestyusa.org/about-us/the-forgotten-prisoners-by-peterbenenson/page.do?id=1101201

Berg, E. J. (1993). Rethinking technical cooperation: Reforms for capacity building in Africa. New York: United Nations Development Program.

Berksoy, B. (2009). Devlet stratejilerinin bir tezahuru olarak polis alt-kulturu: 1960 sonrasi Turkiye'de polis teskilatinda hakim olan soylemlere dair bir degerlendirme [police sub-culture as a manifestation of state strategies: An evaluation regarding dominant discourses in the police organization in post-1960 Turkey]. Toplum ve Bilim, 114, 98-130.

Berksoy, B. G. (2007). The policing of social discontent and the construction of the social body: Mapping the expansion and militarization of the police organization in Turkey in the post-1980 period. Unpublished Ph.D. Dissertation, Bogazici University, Istanbul.

Bese, E. (2006). Special operations unit. In U. Cizre (Ed.), Almanac Turkey 2005. Security sector and democratic oversight (1st ed., pp. 118-127). Istanbul: TESEV. 
Best, A., Hanhimaki, J. M., Maiolo, J. A., \& Schulze, K. E. (2004). International history of the twentieth century: Routledge.

Best, J. (2007). Legitimacy dilemmas: The IMF's pursuit of country ownership. Third World Quarterly, 28(3), 469-488.

Bianet. (2007, June 21). TIHV: Iskence yargilamalari haberi yaniltici [TIHV: News on torture trials misleading]. Retrieved April 19, 2011, from http://bianet.org/bianet/bianet/97866-tihv-iskence-yargilamalari-haberi-yaniltici

Bigo, D. (2000a). Liasion officers in Europe: New officers in the European security field. In J. Sheptycki (Ed.), Issues in transnational policing (pp. 67-99). London: Routledge.

Bigo, D. (2000b). When two become one, internal and external securitisations in Europe. In M. Kelstrup \& M. C. Williams (Eds.), International relations theory and the politics of European integration: Power, security and community (pp. 171-204). New York: Routledge.

Bigo, D. (2001). The mobius ribbon of internal and external security(ies). In M. Albert, D. Jacobson \& Y. Lapid (Eds.), Identities, borders, orders: Rethinking international relations theory. (pp. 91-116). Minneapolis, Minn.: University of Minnesota Press.

Bigo, D. (2002). Security and immigration: Toward a critique of the governmentality of unease. Alternatives, 27(SUPPL. 1), 63-92.

Bigo, D. (2008). Globalized (in)security: 'The field and the ban-opticon. In D. Bigo \& A. Tsoukala (Eds.), Terror, insecurity and liberty: Illiberal practices of liberal regimes after $9 / 11$ (pp. 10-48). London: Routledge.

Bilder, R. B. (1969). Rethinking international human rights: Some basic questions. Wisconsin Law Review, 1969(1), 171-217.

Birand, M. A. (1971, December 7). Buhran ortak pazar'da tepki yaratti [common market reacts to crisis]. Milliyet, pp. 1,9.

Birand, M. A. (2005). Turkiye'nin buyuk Avrupa kavgasi[Turkey's fight for Europe]. Istanbul: Dogan Kitap.

Blyth, M. M. (1997). "any more bright ideas?" the ideational turn of comparative political economy. Comparative Politics, 29(2), 229-250.

Böll, H. (1973, February 18). A plea for meddling. New York Times, p. 259.

Bölügiray, N. (1991). Sokaktaki askerin dönüsü [return of the soldier on the street]. Ankara: Tekin.

Bölügiray, N. (2001). Sokaktaki asker: Bir sikiyönetim komutaninin 12 Eylül anilari [soldier on the street: September 12 memoirs of a martial law commander] (3rd ed.). Istanbul: Tekin Yayinevi.

Bora, T. (1994/2006). Devletin polisi, polisin devleti [the state's police, the police's state]. In Medeniyet kaybi (pp. 203-218). Istanbul: Iletisim.

Bora, T. (2001). Polis partisi [police party]. Retrieved 2010, September 1, from http://www.birikimdergisi.com/birikim/dergiyazi.aspx?did=1\&dsid=130\&dyid $=9$ 2\&yazi=Polis\%20Partisi

Bourdieu, P. (1987). The force of law: Towards a sociology of the juridical field. Hastings Journal of Law, 38, 814-853. 
Bourdieu, P., \& Wacquant, L. (1989). Towards a reflexive sociology: A workshop with Pierre Bourdieu. Sociological Theory, 7(1), 26-63.

Boyle, K., \& Hannum, H. (1974). Individual applications under the European convention on human rights and the concept of administrative practice: The Donnelly case. The American Journal of International Law, 68(3), 440-453.

Bozarslan, H. (2001). Human rights and the Kurdish issue in Turkey: 1984-1999. Human Rights Review, 3(1), 45-54.

Brantingham, P., \& Faust, F. (1976). A conceptual model of crime prevention. Crime \& Delinquency, 22(3), 284-296.

Bristol City Council. (n.d.). Bristol and Hannover partnership. Retrieved April 21, 2010, from http://www.bristol.gov.uk/ccm/content/Leisure-Culture/Tourism-

Travel/twinning-pages/bristol-and-hannoverpartnership.en;jsessionid=DF0C74D39DFC1B3ED6D201F9C9F0EDEB.tcwwwa plaws 1

Bröckling, U., Krasmann, S., \& Lemke, T. (2011). From Foucault's lecture at the Collège de France to studies of governmentality. In U. Bröckling, S. Krasmann \& T. Lemke (Eds.), Governmentality: Current issues and future challenges (pp. 1-33). New York: Routledge.

Bruinessen, M. V. (1996). Turkey's death squads. Middle East Report, 199, 20-23.

Bruno, I., Jacquot, S., \& Mandin, L. (2006). Europeanization through instrumentation: Benchmarking, mainstreaming and open method of coordination... Toolbox or pandora's box. Journal of European Public Policy, 13(4), 519-536.

Buchanan, T. (2002). 'the truth will set you free': The making of Amnesty International. Journal of Contemporary History, 37(4), 575-597.

Burgers, J. H. (1992). The road to San Francisco: The revival of the human rights idea in the twentieth century. Human Rights Quarterly, 14(4), 447-477.

Burgers, J. H., \& Danelius, H. (1988). The United Nations convention against torture: A handbook on the convention against torture and other cruel, inhuman, or degrading treatment or punishment. Dordrecht: Martinus Nijhoff.

Buyck, B. (1991). The bank's use of technical assistance for institutional development. Washington, D.C.: Public Sector Management and Private Sector Development Division, Country Economics Department, World Bank.

Cagaptay, S. (2009, May 15). Behind Turkey's witch hunt. Retrieved May 15, 2009, from http://www.thedailybeast.com/newsweek/2009/05/15/behind-turkey-s-witchhunt.html

Caglar, A. (2003). Policing problems in Turkey: Processes, issues and the future. In S. Einstein \& M. Amir (Eds.), Police corruption: Paradigms, models and concepts challenges for developing countries (pp. 399-432). Huntsville: OICJ.

Cali, B. (2007). Human rights discourse and domestic human rights ngos. In Z. F. K. Arat (Ed.), Human rights in Turkey (pp. 217-232). Pennsylvania: Pennsylvania University Press.

Calkins, L. (2010). Detained and drugged: A brief overview of the use of pharmaceuticals for the interrogation of suspects, prisoners, patients, and pows in the US. Bioethics, 24(1), 27-34. 
Callon, M. (1986). Some elements of a sociology of translation: Domestication of the scallops and the fishermen of St. Brieuc bay. In J. Law (Ed.), Power, action and belief: A new sociology of knowledge? (pp. 196-223). London: Routledge.

Callon, M., \& Latour, B. (1981). Unscrewing the big leviathan. In K. D. Knorr-Cetina \& M. Mulkay (Eds.), Advances in social theory and methodology (pp. 275-303). London: Routledge and Kegan Paul.

Cameron, I. (1988). Turkey and article 25 of the European convention on human rights. International \& Comparative Law Quarterly, 37(04), 887-925.

Canadian Civil Liberties Association. (2010). Breach of the peace: A preliminary report of observations during the $2010 \mathrm{~g} 20$ summit. Retrieved September 2, 2011, from http://ccla.org/wordpress/wp-content/uploads/2010/06/CCLA-Report-A-Breachof-the-Peace-Preliminary-report-updated-July-8.pdf

Cassese, A. (1996). Inhuman states: Imprisonment, detention and torture in Europe today. Oxford, UK: Polity Press.

Catalbas, D. (2007). Freedom of press and broadcasting. In Z. F. K. Arat (Ed.), Human rights policies and practices in Turkey (pp. 19-34). Philadelphia: University of Pennsylvania Press.

Çavdar, G. (2006). Islamist new thinking in Turkey: A model for political learning? Political Science Quarterly, 121(3), 477-497.

Cerrah, I. (1998). Guvenlik hizmetleri ve demokratiklesme [security services and democratization]. Polis Bilimleri Dergisi/Turkish Journal of Police Studies, 1(2), 55-71.

Cerrah, I. (2005, February 3). Ic guvenlik sektorunun 'zihinsel modernizasyonu': Ic guvenlik tehdit algilamasinin 'mesruiyeti' ve sektorun 'demokratik gozetimi" [mental modernization of internal security sector]. Retrieved August 1, 2010, from http://www.tesev.org.tr/UD OBJS/DOC/DEM/03022005-GuvSekDemAcIbrahimCerrahKonusmasi.doc

Cerrah, I. (2008). Democratization of policing: The case of the Turkish police. In M. R. Haberfeld \& I. Cerrah (Eds.), Comparative policing: The struggle for democratization (pp. 183-222). Thousand Oaks: Sage.

Chandler, D. (2004). Constructing global civil society: Morality and power in international relations. London: Palgrave Macmillan.

Chandler, D. (2006). Empire in denial: The politics of state-building. London: Pluto.

Chatterjee, P. (1993). Nationalist thought and the colonial world: A derivative discourse. London: Zed Books.

Chayes, A., \& Chayes, A. H. (1993). On compliance. International Organization, 47(2), 175-205.

Checkel, J. T. (1998). The constructivist turn in international relations theory. World Politics, 50(2), 324-348.

Checkel, J. T. (2001). Why comply? Social learning and European identity change. International Organization, 55(3), 553-588.

Ciloglu, M. (1996, February 11). Insanlik mektebi [school of humanity]. Milliyet, p. 2.

Citir, H. (2003). Kuresellesme ve Turkiye'ye etkileri [globalization and its effects on Turkey]. Cagin Polisi, 17, 28-29. 
Cizova, T. (1962). Beccaria in Russia. The Slavonic and East European Review, 40(95), 384-408.

Cizre, U. (2003). Demythologizing the national security concept: The case of Turkey. Middle East Journal, 57(2), 213-229.

Cizre-Sakallioglu, U. (1997). The anatomy of the Turkish military's political autonomy. Comparative Politics, 29(2), 151-166.

Clark, A. M. (2001). Diplomacy of conscience: Amnesty International and changing human rights norms. Princeton, N.J.: Princeton University Press.

Clarke, N. (2009). In what sense 'spaces of neoliberalism'? The new localism, the new politics of scale, and town twinning. Political Geography, 28(8), 496-507.

Cohen, S. (1996). Government responses to human rights reports: Claims, denials, and counterclaims. Human Rights Quarterly, 18(3), 517-543.

Cole, S. A. (2001). Suspect identities: A history of fingerprinting and criminal identification. Cambridge, MA: Harvard University Press.

Collier, S. J. (2009). Topologies of power: Foucault's analysis of political government beyond 'governmentality'. Theory Culture \& Society, 26(6), 78-108.

Collins, R. (1974). Three faces of cruelty: Towards a comparative sociology of violence. Theory and Society, 1(4), 415-440.

Cooper, L. (1984). The twinning of institutions: Its use as a technical assistance delivery system. Washington, D.C.: World Bank.

Council of Europe. (2009). Combating ill-treatment and impunity. Retrieved September 6, 2011, from http://www.coe.int//dghl/cooperation/capacitybuilding/projects/illtreatment en.asp

Council of Europe. (n.d.). Council of Europe in brief. Retrieved January 27, 2011, from http://www.coe.int/aboutcoe/index.asp?page=47paysleurope\&l=en

Council of Europe Parliamentary Assembly. (1981). Report on the international convention against torture (No. Doc. 4650). Strasbourg: Council of Europe.

Council of European Municipalities and Regions. (n.d.). Twinning: A quick overview. Retrieved April 21, 2010, from http://www.twinning.org/en/page/a-quickoverview.html

Council of Ministers. (2001). 2001 national program for the adoption of the acquis. Retrieved April 1, 2010, from http://www.abgs.gov.tr/index.php?p=58\&l=1 Council of Ministers. (2003). 2003 national program for the adoption of the acquis. Retrieved April 1, 2010, from http://www.abgs.gov.tr/index.php?p=196\&l=2

Cousins, J. (1973). Turkey: Torture and political persecution. London: Pluto Press.

CPT. (1990a). Report to the Turkish government on the visit to Turkey carried out by the European committee for the prevention of torture and inhuman or degrading treatment or punishment [CPT/inf (2007) 1]. Retrieved February 3, 2011, from http://www.cpt.coe.int/documents/tur/2007-01-inf-eng.pdf

CPT. (1990b). Responses of the Turkish government to the report of the European committee for the prevention of torture and inhuman or degrading treatment or punishment (CPT) on its visit to Turkey from 9 to 21 September 1990 [CPT/inf (2007) 2], from http://www.cpt.coe.int/documents/tur/2007-01-inf-eng.pdf

CPT. (1992). Response of the Turkish government to the report of the European committee for the prevention of torture and inhuman or degrading treatment or 
punishment (CPT) on its visit to Turkey from 22 November to 3 December 1992 [CPT/inf (2007) 6]. Retrieved February 11, 2011, from http://www.cpt.coe.int/documents/tur/2007-06-inf-eng.pdf

CPT. (1996, December 6). Public statement on Turkey (issued on 6 December 1996). Retrieved February 15, 2011, from http://www.cpt.coe.int/documents/tur/199634-inf-eng.htm

CPT. (2010a). CPT database. Retrieved May 9, 2011, from http://www.cpt.coe.int/en/database.htm

CPT. (2010b). CPT standards. Retrieved June 14, 2011, from http://www.cpt.coe.int/en/documents/eng-standards.pdf

CSOP. (1973). Building peace; reports of the Commission to study the organization of peace, 1939-1972. Metuchen, N.J.: Scarecrow Press.

Cumhuriyet. (2010, May 6). Durusmada "yeni sorusturma" tansiyonu gerdi [demand for new inquiry heightens tensions in court]. Retrieved September 5, 2010, from http://www.cumhuriyet.com.tr/?hn=137584

Dagi, I. D. (1996). Democratic transition in Turkey, 1980-83: The impact of European diplomacy. Middle Eastern Studies, 32(2), 124-141.

Dagi, I. D. (2000). Insan haklari, kuresel siyaset ve Turkiye [human rights, global politics and Turkey]. Istanbul: Boyut.

Dagi, I. D. (2001). Human rights and democratization: Turkish politics in the European context. Journal of Southeast European and Black Sea Studies, 1(3), 51-68.

Dagi, I. D. (2006). The justice and development party: Identity, politics, and discourse of human rights in the search for security and legitimacy. In $\mathrm{H}$. Yavuz (Ed.), The emergence of a new Turkey and the AK parti (pp. 88-106). Salt Lake City: Utah University Press.

De Lint, W. (1997). Shaping the subject of policing autonomy, regulation and the police constable. Unpublished Doctoral Dissertation, University of Toronto, Toronto.

De Lint, W. (1998). Regulating autonomy: Police discretion as a problem for training. Canadian Journal of Criminology, 40(3), 277-304.

Dean, M. (1994). Critical and effective histories: Foucault's methods and historical sociology. London: Routledge.

Dean, M. (1999). Governmentality: Power and rule in modern society. London: Sage Publications.

Dearing, A. (2005). Sorusturmada isbirligi ve iletisim icin yeni bir model [a new model for cooperation and communication in investigation]. In Ceza yargilamasinda isbirliginin gelistirilmesi: Seminer notlari ve ilgili mevzuat [improvement of cooperation in criminal proceedings: Seminar notes and the relevant legislation] (pp. 15-39). Ankara: Emniyet Genel Mudurlugu.

Delegation of European Commission to Turkey. (2004). Press release: EU supports project to improve statement taking methods and rooms in Turkey. Ankara: Delegation of the European Commission in Turkey.

Delegation of European Commission to Turkey. (n.d.). Strengthening the police forensic capacity. Retrieved May 5, 2010, from http://www.avrupa.info.tr/Duyurular,Duyuru Listesi.html?Mode $=0 \& Y e a r=2004$ \&Month $=12 \&$ RefNo $=\& \operatorname{PrgID}=107$ 
Della, B. C. (2004). Nontraditional training systems. FBI Law Enforcement Bulletin, 73(6), 1-12.

Demir, M. (2001, March 19). Türkiye'yi kurtaracak program [the program that will save Turkey]. Retrieved September 5, 2011, from http://webarsiv.hurriyet.com.tr/2001/03/19/314119.asp

Demirel, T. (2004). Turk silahli kuvvetlerinin toplumsal mesruiyeti uzerine [on the social legitimacy of the Turkish armed forces]. In A. Insel \& A. Bayramoglu (Eds.), Turkiye'de ordu: Bir zumre, bir parti (pp. 345-381). Istanbul: Iletisim.

Democratic Resistance of Turkey. (1972). File on Turkey. n.p.

Dennett, T. (1932). The Lytton report. The American Political Science Review, 26(6), 1148-1151.

Deringil, S. (1989). Turkish foreign policy during the Second World War: An "active" neutrality. Cambridge, UK: Cambridge University Press.

Dezalay, Y., \& Garth, B. (2006). From the cold war to Kosovo: The rise and renewal of the field of international human rights. Annual Review of Law and Social Science, 2, 231-255.

Diamond, L. (1992). Promoting democracy. Foreign Policy, 87, 25-46.

Diez, T. (2005). Constructing the self and changing others: Reconsidering 'normative power Europe'. Millennium - Journal of International Studies, 33(3), 613-636.

Dikici, A. (2009). Demokrat Parti döneminde iç güvenlik ve Türk polis teskilati [homeland security of Turkey during the democrat party period and the Turkish police organization]. Akademik Bakis, 3(5), 61-94.

Dikmen, I. (2010). Insan haklarina zihinsel yaklasim [mental approach to human rights]. Cagin Polisi, 108, 30.

Dimitrova, A., \& Pridham, G. (2004). International actors and democracy promotion in Central and Eastern Europe: The integration model and its limits. Democratization, 11(5), 91-112.

Dönmezer, S., \& Yenisey, F. (2002). Ceza adalet sisteminin etkinligi 1998 [the efficiency of the criminal justice system 1998]. Istanbul: TESEV.

Douzinas, C. (2007). 'left or rights?' Journal of Law and Society, 34(4), 617-632.

Duffield, M. (2007). Development, security and unending war: Governing the world of peoples. Cambridge, UK: Polity Press.

Duffy, P. J. (1983). Article 3 of the European convention on human rights. The International and Comparative Law Quarterly, 32(2), 316-346.

Dundar, A. N. (1997). Avrupa iskenceyi önleme komitesinin ziyaret ve incelemelerinde tespit edilen hususlar [points regarding the visit and examinations of the European committee for the prevention of torture]. Türk Idare Dergisi, 69(415), 57-67.

Durna, T., \& Hancerli, S. (2007). Implementing democratic policing in the PKK terrorism torn areas of Turkey. In O. Nikbay \& S. Hancerli (Eds.), Understanding and responding to the terrorism phenomenon: A multi-dimensional perspective (pp. 326-338). Amsterdam: IOS Press.

Eisenberg, J. (2003). Antonio Vieira and the justification of Indian slavery. LusoBrazilian Review, 40(1), 89-95.

Elden, S. (2007). Governmentality, calculation, territory. Environment and Planning D: Society and Space, 25(3), 562-580. 
Elibol, K. (2008, June 28). Çevik kuvvet'te zihinsel dönüsüm [mental transformation in the riot police]. Retrieved June 9, 2010, from http://www.bugun.com.tr/haberdetay/30065-cevik-kuvvet-te-zihinsel-donusum-haberi.aspx

Emniyet Genel Mudurlugu. (1973). Cumhuriyetin 50. Yilinda icisleri bakanligi [ministry of interior at the 50th anniversary of the republic]. n.p.

Emniyet Genel Mudurlugu. (1995). Onsoz [preface]. In U. Azak \& M. Terzioglu (Eds.), Polis akademisi seminer konferans sempozyum bildiriler dizisi (pp. 13-36). Ankara: Emniyet Genel Mudurlugu.

Emniyet Genel Mudurlugu. (2000a). Emniyet genel mudurlugu 2000 genelgeleri [the circulars of the general directorate of security published in 2000]. Ankara: EGM Arastirma, Planlama, ve Koordinasyon Baskanligi.

Emniyet Genel Mudurlugu. (2006). Ilk ekibin gorev ve sorumluluklari [guide to the duties and responsibilities of the first response team] [brochure]. n.p.

Emniyet Genel Mudurlugu. (n.d.). Kriminal polis laboratuvarlari dairesi baskanligi [directorate of the criminal forensics lab]. Retrieved May 6, 2010, from http://www.emniyet.gov.tr/daire.kriminal.asp

Emniyet Genel Mudurlugu (Ed.). (2000b). Farkli bakis tarzlariyla insan haklari uygulamalari [human rights applications from different perspectives]. Ankara: EGM.

Ennals, M. (1973). After Paris: The future campaign. In Amnesty International (Ed.), Conference for the abolition of torture (pp. 14). London: Amnesty International.

Ercek, M., \& Say, A. (2008). Discursive ambiguity, professional networks, and peripheral contexts: The translation of total quality management in Turkey, 19912002. International Studies of Management and Organization, 38(4), 78-99.

Erdal, M. (2009). Cezasizlik [impunity]. Diyalog, 3, 54-69.

Ergut, F. (2000). State and social control: The police in the late Ottoman Empire and the early republican Turkey, 1839-1939. Unpublished Ph.D. Dissertation, New School for Social Research, New York.

Erogul, C. (1987). The establishment of multiparty rule: 1945-1971 (Rezan Benatar, Irvin Cemil Schick \& Ronnie Margulies, Trans.). In I. C. Schick \& E. A. Tonak (Eds.), Turkey in transition: New perspectives (pp. 101-146). New York: Oxford University Press.

Eryilmaz, M. B. (1999). Arrest and detention powers in English and Turkish law and practice in the light of the European convention on human rights. The Hague: Martinus Nijhoff.

Erzurum Gazetesi. (2005, June 29). Ispanyol danisman Alonso: Turk polisi gercekten basarili [Spanish consultant Alonso: Turkish police really successful]. Retrieved June 21, 2009, from http://www.erzurumgazetesi.com.tr/default.asp?page=haber\&id $=4326$

Euractive Turkey. (2010, June 13). Mevlut Çavusoglu: Avrupa konseyi siyasal bütünlesmeyi saglamak için çalisiyor [Mevlut Çavusoglu: Council of Europe is working to accomplish political integration]. Retrieved January 27, 2011, from http://www.euractiv.com.tr/abnin-gelecegi/interview/mevlut-avuolu-avrupakonseyi-rklkla-mcadele-ediyor-medeniyetleri-buluturuyor-010593 
Euro-Mediterranean Human Rights Network. (2010, October 30). Freedom of association in the Mediterranean region: A threatened civil society. Retrieved May 22, 2011, from http://www.euromedrights.org/files.php?force\&file=emhrn-statements2008/FOA2010 EN FINAL 267726910.pdf

European Commission. (1989). Commission opinion on Turkey's request for accession to the community. Brussels: European Communities.

European Commission. (1997). Agenda 2000: For a stronger and wider Union.

Luxembourg: European Communities.

European Commission. (1999). Regular report on Turkey's progress towards accession. Retrieved May 4, 2010, from http://ec.europa.eu/enlargement/archives/pdf/key documents/1999/turkey en.pdf

European Commission. (2000). Regular report from the Commission on Turkey's progress towards accession. Retrieved May 4, 2010, from http://ec.europa.eu/enlargement/archives/pdf/key documents/2000/tu en.pdf

European Commission. (2001). Twinning in action (October 2001 ed.). Brussels: Information and Interinstitutional Relations Unit.

European Commission. (2006a). Regular report on Turkey's progress towards accession. Retrieved May 4, 2010, from http://ec.europa.eu/enlargement/pdf/key documents/2006/nov/tr sec 1390 en.pd $\underline{\mathrm{f}}$

European Commission. (2006b). Twinning: Building Europe together. Luxembourg: European Communities.

European Commission. (2007). Commission staff working document annexes to the report from the Commission to the Council and the European parliament 2006 report on PHARE, pre-accession and transition instruments country sections \& additional information $\{\operatorname{com}(2007) 679$ final $\}$. Retrieved May 5, 2010, from http://eur-

lex.europa.eu/LexUriServ/LexUriServ.do?uri=CELEX:52007SC1462:EN:HTML

European Commission. (2009). Institution building in the framework of European Union policies: Common twinning manual. Retrieved April 1, 2010, from http://ec.europa.eu/enlargement/pdf/financial assistance/institution building/final version of the manual 2009 clean en.pdf

European Commission. (2011). Pre-accession assistance - twinning. Retrieved July 21, 2011, from http://ec.europa.eu/enlargement/how-does-it-work/technicalassistance/twinning en.htm

European Council. (1993). European Council in Copenhagen 21-22 June 1993. Conclusions of the presidency. Retrieved January 6, 2010, from http://www.consilium.europa.eu/uedocs/cms data/docs/pressdata/en/ec/72921.pdf European Council. (1994). European Council meeting on 9 and 10 December 1994 in Essen: Presidency conclusions. Retrieved April 1, 2010, from http://www.consilium.europa.eu/uedocs/cms data/docs/pressdata/en/ec/003001.EN4.htm

European Court of Human Rights. (1996). Case of Aksoy v. Turkey. Retrieved February 3,2011 , from http://cmiskp.echr.coe.int/tkp197/view.asp?action=html\&documentId=695880\&p 
ortal=hbkm\&source=externalbydocnumber\&table=F69A27FD8FB86142BF01C1 166DEA398649

European Court of Human Rights. (1997). Case of Aydin v. Turkey. Retrieved February 3, 2011, from

http://cmiskp.echr.coe.int/tkp197/view.asp?action=html\&documentId=696248\&p ortal=hbkm\&source $=$ externalbydocnumber\&table $=$ F69A27FD8FB86142BF01C1 166DEA398649

European Parliament. (2011). European parliament resolution of 10 March 2011 on

Belarus (in particular the cases of Ales Mikhalevic and Natalia Radina). Retrieved September 6, 2011, from

http://www.europarl.europa.eu/sides/getDoc.do?type=TA\&reference=P7-TA2011-0099\& format $=X M L \&$ language $=E N$

Evans, M. D., \& Morgan, R. (1998). Preventing torture: A study of the European convention for the prevention of torture and inhuman or degrading treatment or punishment. Oxford: Oxford University Press.

Ewen, S., \& Hebbert, M. (2007). European cities in a networked world during the long 20th century. Environment and Planning C: Government and Policy, 25(3), 327340.

Feld, E. (2006). Developing a Jewish theology regarding torture. Theology Today, 63(3), 324-329.

Ferret, O. (2009). Voltaire: Pamphlets and polemic. In N. Cronk (Ed.), The Cambridge companion to Voltaire (pp. 167-178). Cambridge, UK: Cambridge University Press.

Final report: Improvement of statement taking methods and statement taking rooms in the republic of Turkey. (2005). European Commission.

Finnemore, M., \& Sikkink, K. (1998). International norm dynamics and political change. International Organization, 52(4), 887-917.

Flickr. (2011, March 7). Amnesty Turkey human rights campaign poster, 1980. Retrieved December 5, 2011, from http://www.flickr.com/photos/amnestydeutschland/5506154756/

Flockhart, T. (2005). Complex socialization and the transfer of democratic norms. In T. Flockhart (Ed.), Socializing democratic norms: The role of international organizations for the construction of Europe (pp. 43-61). New York: Palgrave Macmillan.

Forsythe, D. P. (1985). The United Nations and human rights, 1945-1985. Political Science Quarterly, 100(2), 249-269.

Forsythe, D. P. (2006). Human rights in international relations (2nd ed.). Cambridge, UK: Cambridge University Press.

Foucault, M. (1973). Foreword to "I, Pierre Riviere, having slaughtered my mother, my sister, and my brother..." Retrieved May 23, 2011, from http://foucault.info/documents/pierreRiviere/foucault.pierreRiviere.foreword.en.ht $\underline{\mathrm{ml}}$

Foucault, M. (1977). Nietzsche, genealogy, history. In D. F. Bouchard (Ed.), Language, counter-memory, practice: Selected essays and interviews. Ithaca: Cornell University Press. 
Foucault, M. (1979). Discipline and punish, the birth of the prison. New York: Vintage Books.

Foucault, M. (1980a). The history of sexuality, volume i: An introduction. New York: Vintage Books.

Foucault, M. (1980b). Power/knowledge: Selected interviews and other writings, 19721977. New York: Pantheon Books.

Foucault, M. (1991a). Governmentality. In G. Burchell, C. Gordon \& P. Miller (Eds.), The Foucault effect: Studies in governmentality (pp. 87-104). Chicago: University of Chicago Press.

Foucault, M. (1991b). Questions of method. In G. Burchell, C. Gordon \& P. Miller (Eds.), The Foucault effect: Studies in governmentality (pp. 73-86). Chicago: University of Chicago Press.

Foucault, M. (1997). What is enlightenment? In S. Lotringer \& L. Hochroth (Eds.), The politics of truth (pp. 101-135). Los Angeles: Semiotext(e).

Foucault, M. (2000). Power (R. Hurley \& others, Trans. James D. Faubion, ed.). New York: New Press.

Foucault, M. (2003). Society must be defended: Lectures at the Collège de France, 1975 76 (D. Macey, Trans.). New York: Picador.

Foucault, M. (2007a). The incorporation of the hospital into modern technology. In J. W. Crampton \& S. Elden (Eds.), Space, knowledge and power: Foucault and geography (pp. 141-152). Aldershot: Ashgate.

Foucault, M. (2007b). Security, territory, population: Lectures at the Collège de France, 1977-78 (G. Burchell, Trans.). New York: Palgrave Macmillan.

Fougner, T. (2008). Neoliberal governance of states: The role of competitiveness indexing and country benchmarking. Millennium - Journal of International Studies, 37(2), 303-326.

Fraser, D. M. (1977). Freedom and foreign policy. Foreign Policy, 26, 140-156.

Fraser, N. (2003). From discipline to flexibilization? Rereading Foucault in the shadow of globalization. Constellations, 10(2), 160-171.

Freedom House. (n.d.). Freedom in the world. Retrieved May 4, 2010, from http://www.freedomhouse.org/template.cfm?page $=15$

G.D.R. (1976). Torture and other violations of human rights as international crimes. Review (International Commission of Jurists), 17, 41-50.

Ganser, D. (2005). Terrorism in Western Europe: An approach to NATO's secret staybehind armies. Whitehead Journal of Diplomacy and International Relations, 6 , 69-95.

Gautier, J.-J. (1979). Torture: How to make the international convention effective. Geneva: International Commission of Jurists; Swiss Committee Against Torture.

Gemalmaz, S. (1999). The CPT and Turkey. In R. Morgan \& M. D. Evans (Eds.), Protecting prisoners: The standards of the European committee for the prevention of torture in context (pp. 235-263). New York: Oxford University Press.

Genelkurmay Baskanligi. (n.d.). Genelkurmay baskanlari: Ahmet Kenan Evren [chiefs of general staff: Ahmet Kenan Evren]. Retrieved February 10, 2011, from http://www.tsk.tr/1 TSK HAKKINDA/1 2 Genelkurmay Baskanlari/konular/ke nan evren.htm 
General Secretariat of the National Security Council. (1982). 12 September in Turkey: Before and after. Ankara: Ongun Kardesler.

Gilligan, G. (2002). Royal commissions of inquiry. Australian and New Zealand Journal of Criminology, 35(3), 289-307.

Godet, B. (2008). Reforming human rights. Harvard International Review, 29(4), 74-76.

Goldsmith, A. (2009). Turkey, progress towards democratic policing? In M. S. Hinton \& T. Newburn (Eds.), Policing developing democracies (pp. 31-49). New York: Routledge.

Goldstein, J., \& Keohane, R. (1993). Ideas and foreign policy: An analytical framework. In J. Goldstein \& R. Keohane (Eds.), Ideas and foreign policy: Beliefs, institutions, and political change (pp. 3-31). Cornell: Cornell University Press.

Golzuklu, F. (1962). Introduction. In The Turkish code of criminal procedure (pp. 1-11). South Hackensack, NJ: Fred B. Rothman \& Co.

Gordon, C. (1980). Afterword. In C. Gordon (Ed.), Power/knowledge: Selected interviews and other writings, 1972-1977 (pp. 229-259). New York: Pantheon Books.

Gordon, C. (1991). Governmental rationality: An introduction. In G. Burchell, C. Gordon \& P. Miller (Eds.), The Foucault effect: Studies in governmentality (pp. 1-51). Chicago: University of Chicago Press.

Gourisse, B. (2009, November 3). Pluralite des rapport aux normes professionnelles et politisation des pratiques dans la police turque des annees 1970. Retrieved May 5, 2010, from http://ejts.revues.org/index2273.html

Grigoriadis, I. N., \& Ozer, I. (2010). Mutations of Turkish nationalism: From neonationalism to the Ergenekon affair. Middle East Policy, 17(4), 101-113.

Guilhot, N. (2005). The democracy makers: Human rights and the politics of global order. New York: Columbia University Press.

Gunec, S. (2010, May 15). Polis ikinci kez mars yarismasi duzenliyor [second contest organized to find police march]. Retrieved February 28, 2011, from http://www.zaman.com.tr/haber.do?haberno $=984200 \&$ title $=$ polis-ikinci-kezmars-yarismasi-duzenliyor

Gunter, M. M. (1997). The Kurds and the future of Turkey. New York: St. Martin's Press.

Gunter, M. M. (1998). Susurluk: The connection between Turkey's intelligence community and organized crime. International Journal of Intelligence and CounterIntelligence, 11(2), 119-141.

Günver, S. (1989). Kizgin dam uzerinde diplomasi. Avrupali olabilmenin bedeli [diplomacy on a hot tin roof. The price of becoming European]. Istanbul: Milliyet Yayinlari.

Gurel, S. (2010, 8 January). 'agir silahlarin perde arkasi [the hidden side of heavy arms]. Retrieved January 5, 2011, from http://www.hurriyet.com.tr/gundem/13414625.asp

Gureli, N. (1992, December 10). Polisler dizi yazisi [serial: Police]. Milliyet, p. 17.

Gurol, N., \& Seref, D. (2001, August 28). 'gozaltinda bana iskence yaptilar' [i was tortured in custody]. Retrieved February 21, 2011, from

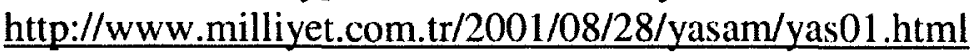


Habermas, J. (1993). The structural transformation of the public sphere: An inquiry into a category of bourgeois society (T. Burger \& F. Lawrence, Trans.). Cambridge, Mass.: The MIT press.

Halici Celik, D. (2007). Ogrenme ve ogretme ilkeleri notu [notes on learning and teaching] [CD ROM]. In Insan haklari: Egiticiler icin kilavuz [human rights: A manual for trainers]. Ankara: Emniyet Genel Mudurlugu Terorle Mucadele ve Harekat Dairesi Baskanligi.

Hall, P. A. (1997). Role of interests, institutions, and ideas in the comparative political economy of the industrialized nations. In M. I. Lichbach \& A. S. Zuckerman (Eds.), Comparative politics: Rationality, culture, and structure (pp. 174-207). Cambridge: Cambridge University Press.

Hall, P. A., \& Taylor, R. C. R. (1996). Political science and the three new institutionalisms. Political Studies, 44, 936-957.

Hanioglu, M. S. (2008). A brief history of the late Ottoman Empire. Princeton: Princeton University Press.

Hannum, H., \& Boyle, K. (1977). The Donnelly case, administrative practice and domestic remedies under the European convention: One step forward and two steps back. The American Journal of International Law, 71(2), 316-321.

Haskell, T. L. (1985). Capitalism and the origins of the humanitarian sensibility, part 1. The American Historical Review, 90(2), 339-361.

Hawtin, G. (1971, September 11). EEC to harmonize credit terms for external trade. The Times, p. 17.

Hay, C., \& Rosamond, B. (2002). Globalization, European integration and the discursive construction of economic imperatives. Journal of European Public Policy, 9(2), 147-167.

Hevener, N. K. (1980). The dynamics of human rights in United States foreign policy. New Brunswick, N.J.: Transaction Books.

Higginson, S. A. (1986). A short history of the right to petition government for the redress of grievances. The Yale Law Journal, 96(1), 142-166.

Hindess, B. (2004). Liberalism - what's in a name? In W. Larner \& W. Walters (Eds.), Global governmentality: Governing international spaces (pp. 23-39). London: Routledge.

Hindess, B. (2005). Citizenship and empire. In T. B. Hansen \& F. Stepputat (Eds.), Sovereign bodies: Citizens, migrants, and states in the postcolonial world (pp. 241-256). Princeton: Princeton University Press.

Hindess, B. (2008). Government and discipline. International Political Sociology, 2(3), 268-270.

Hindess, B. (2009). International anti-corruption as a program of normalization. In L. d. Sousa, P. Larmour \& B. Hindess (Eds.), Governments, ngos and anti-corruption: The new integrity warriors (pp. 19-32). New York: Routledge.

History Commons. (n.d.). Profile: Elliot Abrams. Retrieved May 2, 2011, from http://www.historycommons.org/entity.jsp?entity=elliott abrams

Hockstader, L. (1997, December 14). EU's rejection provokes anger, outrage in Turkey. Retrieved december 13, 2011, from www.lexisnexis.com 
Holcombe, A. N. (1948). Human rights in the modern world. New York: New York Univ. Press.

Horowitz, A., \& Weiss, P. (2009). Israel vs. Human rights. Nation, 289(12), 4, 6.

House of Commons. (1854). Report of the Commission for the investigation of the alleged cases of torture at Madras. London: UK Parliament.

Hughes, R. (1986). The fatal shore: A history of the transportation of convicts to Australia, 1787-1868. London: Collins Harvill.

Human Rights Watch. (1993). The Kurds of Turkey: Killings, disappearances and torture. New York: Human Rights Watch.

Human Rights Watch. (2004, June 1). The legal prohibition against torture. Retrieved July 20, 2011, from http://www.hrw.org/en/news/2003/03/11/legal-prohibitionagainst-torture\#permitted

Human Rights Watch. (2011). Getting away with torture: Bush administration and treatment of detainees. Retrieved September 1, 2011, from http://www.hrw.org/sites/default/files/reports/us0711webwcover.pdf

Hundert, E. J. (1972). The making of homo faber: John Locke between ideology and history. Journal of the History of Ideas, 33(1), 3-22.

Hunt, A., \& Wickham, G. (1994). Foucault and law: Towards a sociology of law as governance. London: Pluto Press.

Hunt, L. (2004). The 18th-century body and the origins of human rights. Diogenes, 51(3), 41-56.

Hurriyet. (1999, August 13). Mafya dedigin cahil ve korkak tipler [mafia is a bunch of ignorant and coward types]. Retrieved May 13, 2009, from http://hurarsiv.hurriyet.com.tr/goster/ShowNew.aspx?id=-95885

Hürriyet. (2001a, August 28). Eyup'te kanli bir cuval bulundu [bag with blood stains found]. Retrieved February 21, 2011, from http://hurarsiv.hurriyet.com.tr/goster/ShowNew.aspx?id=12308

Hürriyet. (2001b, March 19). Yilmaz: Ulusal program, dönüsüm projesi [yilmaz: National program, a project of transformation]. Retrieved September 5, 2011, from http://webarsiv.hurriyet.com.tr/2001/03/19/314097.asp

Hürriyet. (2002, December 5). Yalcinbayir: Iskence insanlik sucu [yalcinbayir: Torture is a crime against humanity]. Retrieved March 11, 2009, from http://arama.hurriyet.com.tr/arsivnews.aspx?id=113750

Hussein, G. M. (2003). Basic guarantees in the Islamic criminal justice system. In M. A. Abdel Haleem, A. O. Sherif \& K. Daniels (Eds.), Criminal justice in Islam: Judicial procedure in the Shari'a (pp. 35-56). London: I.B. Tauris.

Icisleri Bakanligi. (2001). 2001-28 Sayin Yücelen in insan haklari mahkemesi ile ilgili genelgesi [circular regarding European court of human rights by Rt. Hon. Yucelen]. Retrieved June 23, 2011, from http://www.icisleri.gov.tr/default.icisleri 2.aspx?id=2476

Ignatieff, M. (2000). Human rights as politics, human rights as idolatry: Tanner lectures on human values. Retrieved May 2, 2011, from www.tannerlectures.utah.edu/lectures/documents/Ignatieff 01.pdf

Improvement of statement taking methods and statement taking rooms in the republic of Turkey. (2002). Retrieved Apr. 12, 2010, from 
http://ec.europa.eu/enlargement/fiche projet/document/2002-002-55501.01\%20Statement\%20taking\%20methods\%20and\%20rooms.pdf

Inda, J. X. (2005). Analytics of the modern: An introduction. In J. X. Inda (Ed.), Anthropologies of modernity: Foucault, governmentality, and life politics (pp. 120). Malden, MA: Blackwell Pub.

Insan Haklari Dernegi. (n.d.-a). 1995 yili insan haklari ihlalleri bilancosu [human rights violations statement 1995]. Retrieved March 25, 2010, from http://www.ihd.org.tr/images/pdf/1995 yili \%20insan haklari ihlalleri bilancos $\underline{\text { u.pdf }}$

Insan Haklari Dernegi. (n.d.-b). 1996 yili insan haklari ihlalleri bilancosu [human rights violations statement 1996]. Retrieved March 25, 2010, from http://www.ihd.org.tr/images/pdf/1996 yili \%20insan haklari_ihlalleri_bilancos u.pdf

International Commission of Jurists. (1973). The rule of law in Turkey and the European convention on human rights. Review (International Commission of Jurists), 10, 37-56.

Ipekci, A. (1965, March 14). Ortaya cikan gercekler [column: The realities that emerge]. Milliyet, p. 1.

Ishay, M. R. (Ed.). (2007). The human rights reader: Major political essays, speeches, and documents from ancient times to times to the present (2nd ed.). NY: Routledge.

Isik, M. (1999). Polis ve insan haklari 1997-2000 projesi [police and human rights project 1997-2000]. Polis Bilimleri Dergisi/Turkish Journal of Police Studies, 1(3), 101107.

Isleyen, E. (1989, May 4). Ardali polisin davranisini savundu [ardali defends police behaviour]. Milliyet, p. 13.

Istanbul Emniyet Mudurlugu. (2006, April 2006). Gecmisten gunumuze polis kiyafetleri [police uniforms throughout history]. Retrieved November 5, 2010, from http://www.iem.gov.tr/iem/gecmisten gunumuze polis kiyafetleri/index.html

Istanbul Emniyet Mudurlugu. (2007). Mobese. Retrieved April 24, 2007, from http://mobese.iem.gov.tr/

Jane's Islamic Affairs Analyst. (2009, January 29). Gulen movement: Turkey's third power. Retrieved January 5, 2011, from http://search.janes.com.proxy.library.carleton.ca/Search/documentView.do?docId =/content1/janesdata/mags/jiaa/history/jiaa2009/jiaa5183.htm@current\&pageSele cted=allJanes\&keyword=ergenekon\&backPath=http://search.janes.com.proxy.libr ary.carleton.ca/Search\&Prod Name=JIAA\&

Jepperson, R. L., Wendt, A., \& Katzenstein, P. J. (1996). Norms, identity, and culture in national security. In P. J. Katzenstein (Ed.), The culture of national security: Norms and identity in world politics (pp. 33-78). New York: Columbia University Press.

Jesani, A. (1989). Medicine at risk: Health professional as abuser and victim. Economic and Political Weekly, 24(29), 1633-1637.

Jones, D. V. (1994). The League of Nations experiment in international protection. Ethics \& International Affairs, 8(1), 77-95. 
Jones, M. L., \& Blunt, P. (1999). Twinning as a method of sustainable institutional capacity building. Public Administration \& Development, 19(4), 381-402.

Joyce, J. A. (1978). The new politics of human rights. London: Macmillan.

Kabakli, A. (1975). Ic ordu [domestic army]. In S. Yesilyurt (Ed.), 1977 secimlerinden once polis. n.p.

Kadioglu, A. (1996). The paradox of Turkish nationalism and the construction of official identity. Middle Eastern Studies, 32(2), 177-193.

Kahn, P. W. (2008). Sacred violence: Torture, terror, and sovereignty. Michigan: University of Michigan Press.

Kann, R. A. (1960). A study in Austrian intellectual history: From late baroque to romanticism. New York: Praeger.

Kaplan, I. (2006). Onleyici polislik ekseninde 'Turk polisi yazmalidir' meselesi [the issue of writing police officer in the context of preventive policing]. Cagin Polisi(51), 50-53.

Kaplan, I. (2008). Poliste zihinsel modernizasyon [intellectual modernization in Turkish national police]. Unpublished Master's Thesis, Police Academy, Ankara.

Katzenstein, P. J. (1996). Introduction: Alternative perspectives on national security. In P. J. Katzenstein (Ed.), The culture of national security: Norms and identity in world politics (pp. 1-33). New York: Columbia University Press.

Kaygusuz, Z. (2008). Kimlik sorma ve kimlik tespiti [asking for identification and proof of identity]. Polis Bilimleri Dergisi/Turkish Journal of Police Studies, 10(1), 81116.

Kazanci. (1995). I. Polis halk isbirligi sempozyumu [symposium on cooperation between the police and the public]. In U. Azak \& M. Terzioglu (Eds.), Polis akademisi seminer konferans sempozyum bildiriler dizisi. Ankara: Emniyet Genel Mudurlugu.

Keck, M. E., \& Sikkink, K. (1998). Activists beyond borders: Advocacy networks in international politics. Ithaca: Cornell University Press.

Keller, L. M. (2005). Is truth serum torture? American University International Law Review, 20, 521-610.

Kelly, T. (2009). The UN committee against torture: Human rights monitoring and the legal recognition of cruelty. Human Rights Quarterly, 31(3), 777-800.

Kendall, G. (1997). 'governing at a distance': Anglo-Australian relations 1840-70. Australian Journal of Political Science, 32(2), 223-236.

Kendall, G., \& Wickham, G. (2007). The Foucaultian framework. In C. Seale, G. Gobo, J. F. Gubrium \& D. Silverman (Eds.), Qualitative research practice (pp. 129139). London: Sage.

Keyder, C. (1979). Political economy of Turkish democracy. New Left Review, 115, 3-44.

Kihss, P. (1954, February 2). Bayar seeks help to bolster Turks. The New York Times, p. 1.

Kilic, E. (2007). Ozel harp dairesi: Turkiye'nin gizli tarihi [special war directorate: The secret history of Turkey]. Istanbul: Guncel.

Kirisci, K. (2004). The December 2004 European Council decision on Turkey: Is it an historic turning point? Middle East Review of International Affairs, 8(4), 87-94. 
Kirisci, K. (2005). Turkey and the European Union: The domestic politics of negotiating pre-accession. Macalester International, 15, 44-80.

Kirisci, K. (2007). Border management and EU-Turkish relations: Convergence or deadlock (No. 2007/03). Florence: Robert Schuman Center.

Kirkpatrick, J. (1979). Dictatorship and double standards. Commentary, 68(5), 34-45.

Kleinig, J. (2002). Rethinking noble cause corruption. International Journal of Police Science and Management, 4(4), 287-314.

Kocaer, S. (2003, August 20). Bombasavar supurge [anti-bomb broomstick]. Milliyet, p. 5.

Koskenniemi, M. (2002). The gentle civilizer of nations the rise and fall of international law, 1870-1960. Cambridge, UK: Cambridge University Press.

Krasmann, S. (2011). The right of government: Torture and the rule of law. In U. Bröckling, S. Krasmann \& T. Lemke (Eds.), Governmentality: Current issues and future challenges (pp. 115-137). New York: Routledge.

Krasner, S. D. (1993). Sovereignty, regimes, and human rights. In V. Rittberger (Ed.), Regime theory and international relations (pp. 139-167). Oxford: OUP.

Kurasawa, F. (2007). The work of global justice: Human rights as practices. Cambridge, UK: Cambridge University Press.

Landman, T. (2005). Protecting human rights: A comparative study. Washington DC: Georgetown University Press.

Latour, B. (1986). The powers of association. In J. Law (Ed.), Power, action and belief: A new sociology of knowledge (pp. 264-280). London: Routledge and Kegan Paul.

Latour, B. (1987). Science in action: How to follow scientists and engineers through society. Cambridge, MA: Harvard University Press.

Latour, B. (1991a). The impact of science studies on political philosophy. Science, Technology, \& Human Values, 16(1), 3-19.

Latour, B. (1991b). Technology is society made durable. In J. Law (Ed.), A sociology of monsters: Essays on power, technology and domination (pp. 103-131). London: Routledge.

Latour, B. (1992). Where are the missing masses? Sociology of a few mundane artefacts. In W. Bijker \& J. Law (Eds.), Shaping technology, building society: Studies in sociotechnical change (pp. 225-258). Cambridge, MA: MIT Press.

Latour, B. (2000). When things strike back: A possible contribution of 'science studies' to the social sciences. British Journal of Sociology, 51(1), 107-123.

Latour, B. (2005). From realpolitik to dingpolitik - an introduction. In B. Latour \& P. Weibel (Eds.), Making things public: Atmospheres of democracy (pp. 4-31). Cambridge, MA: MIT Press.

Lauren, P. G. (2003). The evolution of international human rights: Visions seen (2nd ed.). Philadelphia: University of Pennsylvania Press.

Lauterpacht Centre for International Law. (2009). Sir Hersch Lauterpacht, 1897-1960. Retrieved December 8, 2009, from

http://www.lcil.cam.ac.uk/about the centre/sir hersch lauterpacht.php

Lauterpacht, H. (1943). The law of nations, the law of nature and the rights of man. Transactions of the Grotius Society, 29, 1-33.

Lauterpacht, H. (1950). International law and human rights. London: Stevens. 
League of Nations. (1935). The aims, methods and activity of the League of Nations. Geneva: Secretariat of the League of Nations.

Leary, V. (1979). A new role for non-governmental organizations in human rights: A case study of non-governmental participation in the development of international norms on torture. In A. Cassese (Ed.), UN law/fundamental rights: Two topics in international law (pp. 197-210). Alphen aan den Rijn: Sijthoff \& Noordhoff.

Leeds, E. (2007). Serving states and serving citizens: Halting steps toward police reform in Brazil and implications for donor intervention. Policing and Society: An International Journal of Research and Policy, 17(1), 21-37.

Lentin, A. (2008). After anti-racism? European Journal of Cultural Studies, 11(3), 311 331.

Levinson, S. (Ed.). (2004). Torture: A collection. Oxford: Oxford University Press.

Leys, C. (1955). Petitioning in the nineteenth and twentieth centuries. Political Studies, 3(1), 45-64.

Lichbach, M. I., \& Zuckerman, A. S. (1997). Research traditions and theory in comparative politics. In M. I. Lichbach \& A. S. Zuckerman (Eds.), Comparative politics: Rationality, culture, and structure (pp. 3-16). Cambridge: Cambridge University Press.

Loft, L. (1992). Toward a more just criminal code in pre-revolutionary France: J.-P. Brissot (1754-1793). Journal of Criminal Justice, 20(2), 121-133.

Lowenheim, O. (2008). Examining the state: A foucauldian perspective on international 'governance indicators'. Third World Quarterly, 29(2), 255-274.

Luban, D. (2005). Liberalism, torture, and the ticking bomb. Virginia Law Review, 91(6), 1425-1461.

Lynch, M. (2011, January 15). Tunisia and the new Arab media space. Retrieved July 19, 2011, from http://lynch.foreignpolicy.com/posts/2011/01/15/tunisia and the new arab medi a space

Lyon, A. (1991, October 3). Turkey's human rights record comes under spotlight. Retrieved February 10, 2010, from http://www.factiva.com

MacBride, S. (1968). The strengthening of international machinery for the protection of human rights. In A. Eide \& A. Schou (Eds.), International protection of human rights (pp. 149-165). Stockholm: Almqvist and Wiksell.

Mack, A. (1975). Counterinsurgency in the third world: Theory and practice. British Journal of International Studies, 1(3), 226-253.

MacMaster, N. (2004). Torture: From Algiers to Abu Ghraib. Race Class, 46(2), 1-21.

Macmillan, A. (2009). Foucault and the examination: A reading of "truth and judicial forms". Journal of Power, 2(1), 155 - 172.

Macmillan, M. O. (2002). Paris 1919: Six months that changed the world. New York: Random House.

Madsen, M. R. (2007). From cold war instrument to supreme European court: The European court of human rights at the crossroads of international and national law and politics. Law \& Social Inquiry, 32(1), 137-159.

Manners, I. (2002). Normative power Europe: A contradiction in terms? JCMS: Journal of Common Market Studies, 40(2), 235-258. 
March, J. G., \& Olsen, J. P. (1998). The institutional dynamics of international political orders. International Organization, 52(4), 943-969.

Marotta, F. (1999). The blue flame and the gold shield: Methodology, challenges and lessons learned on human rights training for police. International Peacekeeping, $6(4), 69-92$.

Marres, N. (2007). The issues deserve more credit. Social Studies of Science, 37(5), 759780.

Martella, P., \& Schunk, J. (1997). Partnership: A new name in development cooperation. Development in Practice, 7(3), 283-286.

Martin Ennals Award Website. (n. d.). Martin Ennals: A giant human rights defender. Retrieved February 1, 2011, from www.martinennalsaward.org/MEA/mea/en/martinennals/index.html

Mater, N. (1992, November 24). Turkey: Human rights activists condemn new torture law. Retrieved February 10, 2010, from http://www.factiva.com

Mavioglu, E., \& Sanyer, R. (2007). 30 yil sonra kanli 1 Mayis [the bloody May Day after 30 years]. Retrieved 2010 , November 1 , from http://www.radikal.com.tr/haber.php?haberno=219999

Mazower, M. (2004). The strange triumph of human rights 1933-1950. The Historical Journal, 47(2), 379-398.

Menzir, N. (1995). Istanbul emniyet mudurlugu polis halkla iliskiler raporu [istanbul directorate of security report on police/public relations]. In U. Azak \& M. Terzioglu (Eds.), Polis akademisi seminer konferans sempozyum bildiriler dizisi (pp. 13-36). Ankara: Emniyet Genel Mudurlugu.

Merlingen, M. (2003). Governmentality: Towards a foucauldian framework for the study of igos. Cooperation and Conflict, 38(4), 361-384.

Merlingen, M., \& Ostrauskaite, R. (2006). European Union peacebuilding and policing. London: Routledge.

Merry, S. E. (2010). Beyond compliance: Toward an anthropological understanding of international justice. In Kamari Maxine Clarke \& M. Goodale (Eds.), Mirrors of justice: Law and power in the post-cold war era (pp. 28-42). Cambridge, UK: Cambridge University Press.

Metin, P. (2011, June 6). 21 cezaevine sivil toplum markaji [civil society focus on 21 prisons]. Retrieved September 2, 2011, from http://www.sabah.com.tr/Yasam/2011/06/06/21-cezaevine-sivil-toplum-markaji

Metzl, J. (1996). Information technology and human rights. Human Rights Quarterly, 18(4), 705-746.

Miller, P., \& Napier, C. (1993). Genealogies of calculation. Accounting Organizations and Society, 18(7-8), 629-645.

Miller, P., \& Rose, N. (1990). Governing economic life. Economy and Society, 19(1), 131.

Milliyet. (1957, April 16). Mevcut 7000 kanun 2000'e indirilecek [the number of laws will be reduced from 7000 to 2000]. Milliyet, p. 1 .

Milliyet. (1974, January 8). Barolar Birligi savunmanin kisitlanmasini elestirdi [bar association criticizes limitation of defense]. Milliyet, pp. 1, 9 .

Milliyet. (1980, September 13). 9 numarali bildiri [communique no. 9]. Milliyet, p. 6. 
Milliyet. (1980, November 8). Gozaltina alma suresi 90 gune kadar uzatilabilecek [detention period can be extended up to 90 days]. Milliyet, p. 8.

Milliyet. (1980, November 22). Polislere selam, saygi, disiplin dersleri verilecek [police to receive lessons on salutation, respect and discipline]. Milliyet, p. 10.

Milliyet. (1982, April 9). Cetiner: 312 belediyede 104 milyon zimmet cikti [corruption in municipalities]. Milliyet, p. 8.

Milliyet. (1982, January 22). Cetiner: 2249 polis isten uzaklastirildi [2249 cops suspended]. Milliyet, p. 3.

Milliyet. (1983, November 23). Emniyetten 3059 kisi cikarildi [3059 persons discharged from the police]. Milliyet, p. 10.

Milliyet. (1984, July 31). Sivil cezaevlerini gezen milletvekilleri baski ve iskenceye rastlamadik dediler [no pressure or torture in civilian prisons: MPs]. Milliyet, p. 6.

Milliyet. (1985, September 1). Polis akademisi yonetmeligi degisti [police academy regulations amended]. Milliyet, p. 6.

Milliyet. (1986, June 6). Iskence yok diyemeyiz [we cannot deny torture]. Milliyet, p. 13.

Milliyet. (1987, July 2). Iskenceci polisler mahkum oldu [torturer cops convicted]. Milliyet, p. 10.

Milliyet. (1992, November 19). CMUK degisiklikleri tamam [CMUK amendments passed]. Milliyet, p. 19.

Milliyet. (1992, November 20). Sloganli cenaze toreni [funeral with slogans]. Milliyet, p. 12.

Milliyet. (1994, December 9). Çiller: Karakolda iskenceye care bulun [Çiller: Find a cure for torture in police stations]. Milliyet, p. 13.

Milliyet. (1994, December 6). MGK'da insan haklari atagi [human rights initiative at the NSC]. Milliyet, p. 14.

Milliyet. (1998, October 23). Cete yasasinda dugmeye basildi [government pushes the button for the law on gangs]. Milliyet, p. 18.

Milliyet. (2002, March 28). Polis 'imdat' dedi [police calls for help]. Milliyet, p. 13.

Mitchell, T. (1991). The limits of the state: Beyond statist approaches and their critics. The American Political Science Review, 85(1), 77-96.

Mitchell, T. (1998). Fixing the economy. Cultural Studies, 12(1), 82-101.

Mitchell, T. (2002). Rule of experts: Egypt, techno-politics, modernity. Berkeley: University of California Press.

Moravcsik, A. (1995). Explaining international human rights regimes: Liberal theory and Western Europe. European Journal of International Relations, 1(2), 157-189.

Morentin, B., Callado, L. F., \& Idoyaga, M. I. (2008). A follow up study of allegations of ill-treatment/torture in incommunicado detainees in Spain. Failure of international preventive mechanisms. Torture: Quarterly journal on rehabilitation of torture victims and prevention of torture, $18(2), 87-98$.

Morgan, R. (2000a). Developing prison standards compared. Punishment Society, 2(3), 325-342.

Morgan, R. (2000b). The utilitarian justification of torture: Denial, desert and disinformation. Punishment Society, 2(2), 181-196.

Morris, I. (1972, November 11). Prisoners of conscience. New York Times, p. 33. 
Morsink, J. (1999). The universal declaration of human rights: Origins, drafting, and intent. Philadelphia: University of Pennsylvania Press.

Moskowitz, M. (1958). Human rights and world order: The struggle for human rights in the United Nations. New York: Oceana Publications.

Moskowitz, M. (1968). The politics and dynamics of human rights. Dobbs Ferry, N.Y.: Oceana Publications.

Muftuler-Bac, M. (1996). Turkey's predicament in the post-cold war era. Futures, 28(3), 255-268.

Mumcu, A. (2007). Osmanli hukukunda zulum kavrami (Revised 3rd ed.). Ankara: Phoenix.

Mutua, M. (2001). Savages, victims, and saviors: The metaphor of human rights. Harvard international law journal, 42(1), 201-245.

Neier, A. (2003). Taking liberties: Four decades in the struggle for rights. New York: PublicAffairs.

New York Times. (1934, September 8). League aim to end fear, Shouse says. New York Times, p. 5.

New York Times. (1948, October 30). Truman stresses Turkey's key role. New York Times, p. 4.

New York Times. (1956, November 15). Hungarian rebel tells of torture: Senate inquiry hears some Soviet troops refused to fight until 'terrorized' saw torture chambers. New York Times, p. 23.

New York Times. (1959, September 22). US and Soviet statements in the UN on the admission of communist China. New York Times, p. 16.

New York Times. (1972, December 3). Martial law jams prisons in Turkey. New York Times, p. 9.

Normand, R., \& Zaidi, S. (2008). Human rights at the UN: The political history of universal justice. Bloomington: Indiana University Press.

Nowak, M. (1998). On the prevention of torture. In B. Duner \& N. Rodley (Eds.), An end to torture: Strategies for its eradication (pp. 247-251). London: Zed Books.

Oberdiek, H. (2007, May 13). Iskence azaldi mi? [did torture decrease?]. Retrieved February 2, 2011, from

http://ob.nubati.net/wiki/\%C4\%B0\%C5\%9Fkence azald\%C4\%B1 m\%C4\%B1\% $\underline{3 F}$

Odyakmaz, Z. (1996). Siyasi partilerin kapatilmasi ile ilgili hükümlerde uyumsuzluklar ve uygulamadaki güçlïkler [incongruities in clauses regarding the banning of political parties and problems in implementation]. Anayasa Yargisi Dergisi, 13, 231-245.

Office of the High Commissioner for Human Rights. (2007a). Convention against torture and other cruel, inhuman or degrading treatment or punishment. Retrieved June 16, 2011, from http://www2.ohchr.org/english/law/cat.htm

Office of the High Commissioner for Human Rights. (2007b). Optional protocol to the international covenant on civil and political rights. Retrieved June 16, 2011, from http://www2.ohchr.org/english/law/ccpr-one.htm

O'Malley, P. (2004). Risk, uncertainly and government. London: Glasshouse Press. 
Oner, S. (2003). Halkin polisi: Pol-der anilari [people's police: Memoirs of pol-der]. Istanbul: lletisim.

Orford, A. (2003). Reading humanitarian intervention: Human rights and the use of force in international law. Cambridge, UK: Cambridge University Press.

Oron, Y. (Ed.). (1961). Middle East record. Vol. 1: 1960. London: published for the Israel Oriental Society, the Reuven Shiloah Research Center, by George Weidenfeld \& Nicolson.

Osborne, T. (1994). Bureaucracy as a vocation: Governmentality and administration in nineteenth-century Britain. Journal of Historical Sociology, 7(3), 289-313.

Osse, A. (2000). Discussion tools: A police and human rights trainer's manual. Strasbourg: Council of Europe.

O'Sullivan, C. D. (2008). Sumner Welles, postwar planning and the quest for a new world order, 1937-1943. Retrieved May 2, 2011, from http://www.gutenberge.org/osc01/index.html

Owen-Davies, J. (1989, March 24). Motives of human rights critics questioned. Retrieved February 10, 2010, from http://www.factiva.com

Ozcan, M. (2000). Avrupa Birligi Turkiye iliskilerinde temel belirleyici unsur olarak insan haklari [human rights as the fundamental determinant of EU-Turkey relations]. Polis Bilimleri Dergisi/Turkish Journal of Police Studies, 2(5-6), 8797.

Ozdag, U., \& Aydinli, E. (2003). Winning a low intensity conflict: Drawing lessons from the Turkish case. In E. Inbar (Ed.), Democracies and small wars (pp. 101-121). London: Frank Cass.

Ozdemir, C. (2009). Onemli isler dairesi: Derin devletin yeni sahibi (the directorate for significant affairs: The new owner of the deep state]. Istanbul: Dogan.

Ozdemir, E. (2001). Polisten polise 3310 merkez [from cop to cop]. Edirne: Il Ozel Idare Matbaasi.

Ozkavak, M. (2003). Insan haklari bizim (polis) icin nedir? [what does human rights mean for us (the police)?]. Cagin Polisi Dergisi, 2(19), 60-61.

Ozkorul, I. (n.d.). Ifade ve sorgu [statement and interrogation]. Retrieved September 5, 2009, from http://www.ceza-bb.adalet.gov.tr/makale/190.doc

Pagden, A. (2003). Human rights, natural rights, and Europe's imperial legacy. Political Theory, 31(2), 171-199.

Pandolfi, M. (2002). 'moral entrepreneurs', souverainetés mouvantes et barbelés. Anthropologie et Sociétés, 26(1), 29-51.

Pandolfi, M. (2010). From paradox to paradigm: The permanent state of emergency in the Balkans. In D. Fassin \& M. Pandolfi (Eds.), Contemporary states of emergency: The politics of military and humanitarian interventions (pp. 153-172). New York: Zone Books.

Papadimitriou, D., \& Phinnemore, D. (2003). Exporting europeanization to the wider Europe: The twinning exercise and administrative reform in the [EU accession] candidate countries and beyond. Journal of Southeast European and Black Sea Studies, 3(2), 1-22.

Parla, T. (n.d.). Turkiye'de anayasalar[constitutions in Turkey]. n.p.: Iletisim. 
Parla, T., \& Davison, A. (2004). Corporatist ideology in Kemalist Turkey: Progress or order? Syracuse: Syracuse University Press.

Parliamentary Assembly of the Council of Europe. (1980). Recommendation 904 on the situation in Turkey. Retrieved February 1, 2010, from http://assembly.coe.int/Mainf.asp?link=/Documents/AdoptedText/ta80/EREC904. htm

Pavlich, G. (2010). Legal judgment and cape colonial law. Law, Culture and the Humanities, 20(10), 1-12.

Peers, D. (1991). Torture, the police and the colonial state in Madras presidency, 18161855. Criminal Justice History, 12, 29-56.

Peters, E. (1996). Torture (Expanded ed.). Philadelphia: University of Pennsylvania Press.

Philip, B. (2009). Analysing the politics of self-help books on depression. Journal of Sociology, 45(2), 151-168.

Pion-Berlin, D. (1988). The national security doctrine, military threat perception, and the 'dirty war' in Argentina. Comparative Political Studies, 21(3), 382-407.

Polat, O. (2007). Ozluk haklari ile ilgili calismalarimiz [efforts for employee rights]. Cagin Polisi, 69, 2-5.

Posel, D. (2008). History as confession: The case of the South African truth and reconciliation Commission. Public Culture, 20(1), 119-141.

Power, J. (1981). Amnesty International, the human rights story. New York: McGrawHill.

Price, R. (1995). A genealogy of the chemical weapons taboo. International Organization, 49(1), 73-104.

Pritz, C., Weyss, B., Dudek, K., Klaushofer, R., Lamplot, P., \& Speiser, E. (2005). Statement taking methods and human rights training manual. Ankara.

Proctor, R. (2000). Twinning and the South Africa/Canada programme on governance: Some reflections on Blunt, Jones and Askvik. Public Administration \& Development, 20(4), 319-325.

Radikal. (2000, December 13). Çevik kuvvet ayaklandi [riot police rises up]. Retrieved June 22, 2011, from http://www.radikal.com.tr/2000/12/13/turkiye/01 cev.shtml

Rajagopal, B. (2003). International law from below: Development, social movements, and third world resistance. New York: Cambridge University Press.

Rao, A. (2001). Problems of violence, states of terror: Torture in colonial India. Interventions, 3(2), 186 - 205.

Rappard, W. E. (1946). Human rights in mandated territories. The ANNALS of the American Academy of Political and Social Science, 243(1), 118-123.

Rare Books Blog. (2011, September 24). Justice as a sign of the law: Justice and punishment. Retrieved December 5, 2011, from http://library.law.yale.edu/blogs/rare-books-blog/2011/09/24/justice-sign-lawjustice-and-punishment

Rawls, J. (1999). A theory of justice (Revised ed.). Cambridge, MA: The Belknap Press of Harvard University Press. 
Reckwitz, A. (2002). The status of the "material" in theories of culture: From "social structure" to "artefacts". Journal for the Theory of Social Behaviour, 32(2), 195217.

Redden, K. (1957). Strengthening the ties of free nations: The first Turkish-American law conference. American Bar Association Journal, 43(12), 1111-1112.

Redfield, P. (2005). Foucault in the tropics: Displacing the panopticon. In J. X. Inda (Ed.), Foucault and the anthropology of modernity (pp. 50-79). Malden, MA: Blackwell.

Redfield, P. (2008). Sacrifice, triage and global humanitarianism. In M. Barnett \& T. Weiss (Eds.), Humanitarianism in question: Politics, power, ethics (pp. 196-214). Ithaca: Cornell University Press.

Rejali, D. M. (2007). Torture and democracy. Princeton: Princeton University Press.

Reymond, N. (2011, March 15). Every revolution has the means of communication that it requires. Retrieved July 19,2011 , from http://fleishman.nl/2011/03/15/\%E2\%80\%98every-revolution-has-the-means-ofcommunication-that-it-requires\%E2\%80\%99/?lang=en

Reza, S. (2007). Torture and Islamic law. Chicago Journal of International Law, 8(1), 21-41.

Risse, T., Ropp, S., \& Sikkink, K. (1999). The power of human rights: International norms and domestic change. Cambridge, UK: Cambridge University Press.

Risse, T., \& Sikkink, K. (1999). The socialization of international human rights norms into domestic practices: Introduction. In T. Risse, K. Sikkink \& S. C. Ropp (Eds.), The power of human rights: International norms and domestic change (pp. 1-38). Cambridge: Cambridge University Press.

Robertson, A. H. (1960). The European court of human rights. The American Journal of Comparative Law, 9(1), 1-28.

Rodley, N. S., \& Pollard, M. (2009). The treatment of prisoners under international law (3rd ed.). Oxford: Oxford University Press.

Ron, J., Ramos, H., \& Rodgers, K. (2005). Transnational information politics: NGO human rights reporting, 1986-2000. International Studies Quarterly, 49(3), 557587.

Rose, N. (1991). Experts of the soul. Psychologie und Geschichte, 3(1/2), 91-99.

Rose, N. (1999a). Inventiveness in politics. Economy and Society, 28(3), 467-493.

Rose, N. (1999b). Powers of freedom: Reframing political thought. Cambridge, UK: Cambridge University Press.

Rose, N., \& Miller, P. (1992). Political power beyond the state: Problematics of government. British Journal of Sociology, 43(2), 173-205.

Rosenbaum, L. (1975). Government by torture. Worldview, 18(4), 21-27.

Rudolph, H. (1984). Security, terrorism, and torture: Detainees' rights in South Africa and Israel: A comparative study. Cape Town: Juta.

Ruthven, M. (1978). Torture: The grand conspiracy. London: Weidenfeld \& Nicolson,.

Ryan, B. J. (2008). The logic of a justified hope: The dialectic of police reform in Northern Ireland. Capital \& Class, 95, 83-107.

Safak, A. (1991). Ceza muhakeme usulu ve polis [crimical procedure and the police]. Ankara: Adalet Matbaacilik. 
Sahiner, D. (2008, June 9, 2008). Hedef polis mi, rejim mi? [is the target the police or the regime?]. Retrieved August 5, 2010, from http://www.zaman.com.tr/haber.do?haberno $=699778$

Said, E. W. (2003). Orientalism. London: Penguin.

Samli, G. (1974). Iskence [torture]. Ankara: Tan.

Sancar, M., \& Atilgan, E. U. (2009). 'adalet biraz es geçiliyor...':Demokratiklesme sürecinde hâkimler ve savcilar ['justice can be bypassed sometimes': Judges and prosecutors in the democratization process]. Istanbul: TESEV.

Sardan, T. (2008). 'ulusalcilik' terör dosyasina girdi [neo-nationalism included in the file on terror]. Retrieved June 30, 2011, from http://www.milliyet.com.tr/-ulusalcilik-teror-dosyasina-girdi/siyaset/haberdetayarsiv/29.03.2008/510805/default.htm

Sariibrahimoglu, L. (2006). Gendarmerie. In U. Cizre (Ed.), Almanac Turkey 2005. Security sector and democratic oversight (1st ed., pp. 100-111). Istanbul: TESEV.

Savas, K. (1997). Basbakanlik teftis kurulu baskani Kutlu Savas'in Susurluk raporu [Susurluk report by the head of prime ministerial inspection Council Kutlu Savas]. Retrieved 2009, January 6, from http://akgul.bilkent.edu.tr/Dava/susurluk/kutlu/p1.html

Schimmelfennig, F., Engert, S., \& Knobel, H. (2003). Costs, commitment and compliance: The impact of EU democratic conditionality on Latvia, Slovakia and Turkey. Journal of Common Market Studies, 41(3), 495-518.

Scott, J. C. (1998). Seeing like a state: How certain schemes to improve the human condition have failed. New Haven: Yale University Press.

Secretariat General for EU Affairs. (2008). Twinning projects (institution based). Retrieved Apr. 5, 2010, from http://www.abgs.gov.tr/index.php?p=40990\&l=2

Sener, N. (2010, June 24). 26 yilin kanli bilancosu [the bloody balance sheet of 26 years]. Retrieved June 24, 2010, from http://www.milliyet.com.tr/26-yilin-kanlibilancosu/guncel/haberdetay/24.06.2010/1254711/default.htm

Senol, M. (2002). Latest developments regarding human rights in Turkey. In V. Yucel \& S. Ruysdael (Eds.), New trends in Turkish foreign affairs: Bridges and boundaries (pp. 307-317). San Jose: Writers Club Press.

Shaw, M. (2000). Theory of the global state: Globality as unfinished revolution. Cambridge, UK: Cambridge University Press.

Shaw, S. J., \& Shaw, E. K. (1976). History of the Ottoman Empire and modern Turkey. Reform, revolution, and republic: The rise of modern Turkey 1808-1975 (Vol. 2). Cambridge: Cambridge University Press.

Sikkink, K. (1993). Power of principled ideas: Human rights policies in United States and Western Europe. In J. Goldstein \& R. Keohane (Eds.), Ideas and foreign policy: Beliefs, institutions, and political change (pp. 139-172). Cornell: Cornell University Press.

Silverman, L. (2001). Tortured subjects: Pain, truth, and the body in early modern France. Chicago: University of Chicago Press.

Sinclair, G., \& Williams, C. A. (2007). 'home and away': The cross-fertilisation between 'colonial' and 'British' policing, 1921-85. The Journal of Imperial and Commonwealth History, 35(2), 221-238. 
Smuts, J. C. (1918). The League of Nations; a practical suggestion. New York: Stoughton.

Solomon, T. (2006). Norms and human rights in international relations. Political Studies Review, 4(1), 36-47.

Spector, P. (1997). Training of trainers. In G. J. Andreopoulous \& R. P. Claude (Eds.), Human rights education for the twenty-first century (pp. 176-193). Philadelphia: University of Pennsylvania Pres.

Strengthening forensic capacity of Turkey. (2003). Retrieved April 12, 2010, from http://ec.europa.eu/enlargement/pdf/turkey/ipa/2008/tr080214 strenghtening fore nsic capacity of turkey-final en.pdf

Strengthening the accountability, efficiency and effectiveness of the Turkish national police. (2003). Retrieved April 12, 2010, from http://www.avrupa.info.tr/Files//Strengthening-accountability-police.pdf

Svensson, J. (2009). The regulation of rule-following. Imitation and soft regulation in the European Union. Stockholm: Stockholm University.

Swardson, A. (1997, December 13). European Union excludes Turkey from expansion plans. Retrieved December 13, 2011, from www.lexisnexis.com

Tachau, F., \& Heper, M. (1983). The state, politics, and the military in Turkey. Comparative Politics, 16(1), 17-33.

Tahincioglu, G. (2005, August 28). Cicek'ten emniyete 'yetki' hatirlatmasi [cicek reminds police their powers]. Retrieved February 19, 2011, from http://www.milliyet.com.tr/2005/08/28/siyaset/axsiy01.html

Tanor, B. (1994). Türkiye'nin insan haklari sorunu. Istanbul: BDS.

Taylor, B. D. (2006). Law enforcement and civil society in Russia. Europe - Asia Studies, 58(2), 193-213.

TBMM Insan Haklarini Inceleme Komisyonu. (2003). Izmir - Aydin raporu [izmir Aydin report]. Retrieved June 21, 2011, from http://www.tbmm.gov.tr/komisyon/insanhaklari/belge/kr izmir31072003.pdf

TBMM Insan Haklarini Inceleme Komisyonu. (2009a). Insan haklarini inceleme komisyonu [human rights inquiry Commission]. Retrieved January 7, 2010, from http://www.tbmm.gov.tr/komisyon/insanhaklari/bilgi.htm

TBMM Insan Haklarini Inceleme Komisyonu. (2009b). Istanbul ilindeki karakollarda yapilan inceleme sonucunda hazirlanan rapor [report on the police stations in istanbul]. Ankara: TBMM.

Terorle Mucadele Dairesi Baskanligi. (n.d.). Degerlendirme ve sonuc. Retrieved February 19, 2009, from http://www.egm.gov.tr/temuh/insanhaklarilo.htm

Terorle Mucadele Ve Harekat Dairesi Baskanligi. (2007). Insan haklari: Egiticiler icin kilavuz [human rights: A manual for trainers]. Ankara: Emniyet Genel Mudurlugu Terorle Mucadele ve Harekat Dairesi Baskanligi.

Tinal, M. (2000). Türkiye'de bir sivil toplum örgütü: Insan haklari dernegi[a civil society organization in Turkey: Human rights association]. Çagdas Türkiye Tarihi Arastirmalari Dergisi, 3(9-10), 117-121.

Today's Zaman. (2008a, April 16). PM Erdogan confident AK party won't be closed. Retrieved March 13, 2009, from 
http://www.todayszaman.com/newsDetail getNewsById.action?load=detay\&link $\equiv 139194$

Today's Zaman. (2008b, January 24). Turkey determined to purge its gladio. Retrieved November 1, 2010, from

http://www.todayszaman.com/newsDetail_getNewsById.action?load=detay\&link $=132371$

Today's Zaman. (2009, June 29). PM Erdogan accuses CHP of hiding behind military. Retrieved January 5, 2011, from http://www.todayszaman.com/news-179364-pmerdogan-accuses-chp-of-hiding-behind-military.html

Toksoz, F. (1993). Kolluk kuvvetleri [law enforcement]. In Cumhuriyet donemi Turkiye ansiklopedisi (Vol. 6, pp. 1626-1636). Istanbul: Iletisim.

Tolley, H. (1994). The international Commission of jurists: Global advocates for human rights. Philadelphia, PA: University of Pennsylvania Press.

Tolley, H., Jr. (1989). Popular sovereignty and international law: ICJ strategies for human rights standard setting. Human Rights Quarterly, 11(4), 561-585.

Tomalová, E. K., \& Tulmets, E. (2007). Twinning projects: Analysing the experience of "old" EU member states and evaluating the benefits of twinning out for the "new" EU member states. In M. Egeberg (Ed.), Institutional dynamics and the transformation of executive politics in Europe (pp. 379-428). Mannheim: Connex.

Tonge, D. (1984, May 14). Turkey cannot afford any more zig-zags. Interview with Turkey's new prime minister. Financial Times, p. 3.

Toth, S. A. (2003). The lords of discipline. The penal colony guards of New Caledonia and Guyana. Crime, Histoire et Societes, 7(2), 41-60.

Traynor, I. (2004, November 26). US campaign behind the turmoil in Kiev. Retrieved December 30, 2010, from

http://www.guardian.co.uk/world/2004/nov/26/ukraine.usa

Tulmets, E. (2005a). The introduction of the open methods of coordination in the European enlargement policy: Analysing the impact of the new PHARE/twinning instrument. European Political Economy Review, 3(1), 54-90.

Tulmets, E. (2005b). The management of new forms of governance by former accession countries of the European Union: Institutional twinning in Estonia and Hungary. European Law Journal, 11(5), 657-674.

Turk Ceza Hukuku Dernegi. (n.d.). Ord. Prof. Dr. Sulhi Dönmezer özet biyografisi [short biography of ord. Prof. Dr. Sulhi Dönmezer]. Retrieved December 15, 2009, from http://www.tchd.org.tr/MenuContent.aspx?id=67

Turkish Daily News. (1996, June 25). Ten policemen tried on torture charges. Retrieved February 14, 2011, from http://www.hurriyetdailynews.com/h.php?news=tenpolicemen-tried-on-torture-charges-1996-06-25

Turkiye Cumhuriyeti Basbakanlik. (1973). Beyaz kitap: Turkiye gercekleri ve terorizm [white book: Turkey's realities and terrorism]. Ankara: Ajans-Turk Matbaacilik Sanayii.

Turkiye Insan Haklari Vakfi. (1996). Iskence dosyasi [dossier on torture] (2nd ed.). Ankara: TIHV.

Tursan, H. (2004). Democratisation in Turkey: The role of political parties. Brussels: Peter Lang. 
Tusalp, E. (1986). Insan haklari dosyasi. Bin insan [human rights file. Thousand humans]. Istanbul: Tekin.

Tutkun, K. Y. (2010). Emniyet teskilati simgesinin ve üniformasinin gelisimi ve degisimine kisa bir bakis [a short look at the development and transformation of symbols and uniforms of the security organization]. Cagin Polisi Dergisi, 102, 35-37.

Ugur, M. (2004). Avrupa Birligi ve Turkiye: Bir dayanak/inandiricilik ikilemi [European Union and Turkey: An anchor/credibility dilemma]. Istanbul: Agora.

UN. (1975). Yearbook of the United Nations. Retrieved January 5, 2010, from http://unyearbook.un.org/unyearbook.html?name=1975index.html

UN. (1983). Human rights: A compilation of international instruments. Ottawa: Human Rights Directorate, Secretary of State.

UN Commission on Human Rights. (1986). Report by the special rapporteur, Mr. P. Kooijmans, appointed pursuant to Commission on human rights resolution 1985/33 (E/CN.4/1986/15). Retrieved February 20, 2009, from http://ap.ohchr.org/documents/E/CHR/report/E-CN 4-1986-15.pdf

UN Commission on Human Rights. (1989a). Report by the special rapporteur, Mr. P. Kooijmans, pursuant to Commission on human rights resolution 1989/33 (E/CN.4/1990/17). Retrieved July 2, 2011, from http://daccess-ddsny.un.org/doc/UNDOC/GEN/G89/140/88/PDF/G8914088.pdf

UN Commission on Human Rights. (1989b). Report of the special rapporteur on torture (incl. Visits to Peru, Republic of Korea and Turkey) (E/CN.4/1989/15). Retrieved January 2, 2010, from http://daccess-ddsny.un.org/doc/UNDOC/GEN/G89/102/26/PDF/G8910226.pdf?OpenElement

UN General Assembly 26th Session. (1971). Town twinning as a means of international cooperation [2861 (xxvi)]. Retrieved July 16, 2011, from http://daccess-ddsny.un.org/doc/RESOLUTION/GEN/NRO/328/77/IMG/NR032877.pdf?OpenElem ent

Valverde, M. (2007). Genealogies of European states: Foucauldian reflections. Economy and Society, 36(1), 159-178.

Veyne, P. (1997). Foucault revolutionizes history. In A. I. Davison (Ed.), Foucault and his interlocutors (pp. 146-182). Chicago: University of Chicago Press.

Vidal-Naquet, P. (1963). Torture: Cancer of democracy, France and Algeria 1954-1962 (B. Richard, Trans.). Harmondsworth, Middlesex: Penguin Books.

Vieira, A. (1653/1966). Vieira's sermon condemning Indian slavery. In E. B. Burns (Ed.), A documentary history of Brazil. New York: Knopf.

Voltaire. (1778). Prix de la justice et de l'humanité. London: [s.n.].

Voltaire. (1912). Toleration and other essays (J. MacCabe, Trans.). New York and London: G.P. Putnam's Sons.

Voltaire. (1994). Political writings (D. Williams, Trans.). New York: Cambridge University Press.

Vural, M. Z. (1970). Polis gorev ve yetkileri [police duties and powers]. Istanbul: Ulutas Matbaasi. 
Walker, M., Roberts, S. M., Jones, J. P., \& Frohling, O. (2008). Neoliberal development through technical assistance: Constructing communities of entrepreneurial subjects in Oaxaca, Mexico. Geoforum, 39(1), 527-542.

Wallace, L. (1990). Reshaping technical assistance. Finance and Development, 27(4), 26. Walters, W. (2008). Anti-policy and anti-politics: Critical reflections on certain schemes to govern bad things. European Journal of Cultural Studies, 11(3), 267-288.

Walters, W., \& Haahr, J. H. (2005a). Governing Europe: Discourse, governmentality and European integration. London: Routledge.

Walters, W., \& Haahr, J. H. (2005b). Governmentality and political studies. European Political Science, 4, 288-300.

Weeramantry, C. G. (Ed.). (1990). Human rights and scientific and technological development. Tokyo: United Nations University Press.

Wendt, A. (1995a). Anarchy is what states make of it. In J. D. Derian (Ed.), International theory: Critical investigations (Vol. 20, pp. 129-177). NY: New York University Press.

Wendt, A. (1995b). Constructing international politics. International Security, 20(1), 7181.

Weston, B. H. (1984). Human rights. Human Rights Quarterly, 6(3), 257-283.

Weyreter. (2003). German twinning movement. Contemporary Review, 282(1644), 37 43.

White, F. (1926). Mandates. London: Jonathan Cape.

Wikisource. (n.d.). Polis marsi [police march]. Retrieved November 1, 2010, from http://tr.wikisource.org/wiki/Polis_Mar\%C5\%9F\%C4\%B1

Wilson, J. Q. (1985). Thinking about crime (Revised ed.). New York: Vintage.

Wilson, R. A. (2009). Representing human rights violations: Social contexts and subjectivities. In M. Goodale (Ed.), Human rights: An anthropological reader (pp. 209-228). Malden, MA: Wiley-Blackwell.

Wright, Q. (1930/1968). Mandates under the League of Nations. New York: Greenwood.

Yegen, M. (1999). The Kurdish question in Turkish state discourse. Journal of Contemporary History, 34(4), 555-568.

Yinanc, B. (1995, March 12). Çiller'in cabasi komiteyi ikna etmedi [Çiller fails to convince committee]. Milliyet, p. 12.

Yuksel, A. (1996). Turk polis teskilatinin yeniden yapilandirilmasi [restructuring the Turkish police organization]. Turk Idare Dergisi, 68(413), 1-6.

Zaman. (2011, February 28). Emre Uslu: 28 Subat'i arastirmak için meclis arastirma komisyonu kurulmali [Emre Uslu: Parliamentary inquiry necessary for 28 February]. Retrieved May 22, 2011, from http://www.zaman.com.tr/haber.do?haberno=1100379\&title=emre-uslu-28subati-arastirmak-icin-meclis-arastirma-komisyonu-kurulmali

Zanotti, L. (2005). Governmentalizing the post-cold war international regime: The UN debate on democratization and good governance. Alternatives: Global, Local, Political, 30(4), 461-487.

Zelinsky, W. (1991). The twinning of the world: Sister cities in geographic and historical perspective. Annals of the Association of American Geographers, 81(1), 1-31.

Zürcher, E. J. (2004). Turkey: A modern history (3rd ed.). London: I.B. Tauris. 
Appendix

Comprehensive List of Interviews

\begin{tabular}{|c|c|c|c|c|}
\hline $\begin{array}{l}\text { Interview } \\
\text { No. }\end{array}$ & Name & Identity & Place & Date \\
\hline 1 & Anonymous & EU Official & Brussels & June 6,2007 \\
\hline 2 & Karl-Heinz Grundboeck & Twinning Expert & Vienna & June 7,2007 \\
\hline 3 & Anonymous & Scholar, Twinning Expert & Vienna & June 8,2007 \\
\hline 4 & Anonymous & Scholar, Twinning Expert & Vienna & June 8,2007 \\
\hline 5 & Anonymous & EU Official & Ankara & June 19,2007 \\
\hline 6 & Anonymous & Police Official & Ankara & June 26,2007 \\
\hline 7 & Anonymous & Police Officer & Ankara & June 26,2007 \\
\hline 8 & Anonymous & Human Rights Advocate & Ankara & June 27,2007 \\
\hline 9 & Anonymous & Expert/Public Official & Ankara & June 28,2007 \\
\hline 10 & Anonymous & Police Official & Ankara & June 29,2007 \\
\hline 11 & Anonymous & Police Official & Ankara & June 30,2007 \\
\hline 12 & Anonymous & Public Prosecutor & Istanbul & July 1,2007 \\
\hline 13 & Anonymous & Police Officer & Istanbul & May 5, 2008 \\
\hline 14 & Saadettin Tantan & Former Minister of Interior & Istanbul & May 7,2008 \\
\hline 15 & Adnan Gerger & Journalist & Ankara & May 12,2008 \\
\hline 16 & Anonymous & $\begin{array}{l}\text { Public Official, Office of the } \\
\text { Prime Minister }\end{array}$ & Ankara & May 13,2008 \\
\hline 17 & Anonymous & Journalist & Ankara & May 15,2008 \\
\hline 18 & Anonymous & $\begin{array}{l}\text { Public Official, Ministry of } \\
\text { Interior }\end{array}$ & Ankara & May 18,2008 \\
\hline 19 & Anonymous & Human Rights Advocate & Izmir & May 26,2008 \\
\hline
\end{tabular}

